\title{
Ervaren pioniers : omgaan met twijfel in de intensive care voor pasgeborenen
}

Citation for published version (APA):

Mesman, J. (2002). Ervaren pioniers : omgaan met twijfel in de intensive care voor pasgeborenen.

[Doctoral Thesis, Maastricht University]. Aksant. https://doi.org/10.26481/dis.20020628jm

Document status and date:

Published: 01/01/2002

DOI:

10.26481/dis.20020628jm

Document Version:

Publisher's PDF, also known as Version of record

\section{Please check the document version of this publication:}

- A submitted manuscript is the version of the article upon submission and before peer-review. There can be important differences between the submitted version and the official published version of record.

People interested in the research are advised to contact the author for the final version of the publication, or visit the DOI to the publisher's website.

- The final author version and the galley proof are versions of the publication after peer review.

- The final published version features the final layout of the paper including the volume, issue and page numbers.

Link to publication

\footnotetext{
General rights rights.

- You may freely distribute the URL identifying the publication in the public portal. please follow below link for the End User Agreement:

www.umlib.nl/taverne-license

Take down policy

If you believe that this document breaches copyright please contact us at:

repository@maastrichtuniversity.nl

providing details and we will investigate your claim.
}

Copyright and moral rights for the publications made accessible in the public portal are retained by the authors and/or other copyright owners and it is a condition of accessing publications that users recognise and abide by the legal requirements associated with these

- Users may download and print one copy of any publication from the public portal for the purpose of private study or research.

- You may not further distribute the material or use it for any profit-making activity or commercial gain

If the publication is distributed under the terms of Article $25 \mathrm{fa}$ of the Dutch Copyright Act, indicated by the "Taverne" license above, 
ERVAREN PIONIERS 
Verschenen in deze serie:

Anja Krumeich

THE BLESSINGS OF MOTHERHOOD

Health, pregnancy and child care in Dominica

ISBN 90-73502-94-7

Sjaak van der Geest, Paul ten Have,

Gerhard Nijhof \& Piet Verbeek-Heida (redactie)

DE MACHT DER DINGEN

Medische sechnologie in cultureel perspectief

ISBN 90-5589-003-0

Cor Hoffer

ISLAMITISCHE GENEZERS EN HUN PATIENTEN

Gezondheidszorg, religie en zingeving

$I S B N$ 90-5s89-0og-x

Ria Reis

SPOREN VAN ZIEKTE

Medische pluraliteit en epilepsie in Swaziland

ISBN 90-5589-050-2

Peter Ventevogel

WHITEMANS THINGS

Training and detraining healers in Ghana

ISBN 90-5589-046-4

Anne V. Reeler

MONEY AND FRIENDS

Modes of empowerment in Thai health care

ISBN 90-5589-076-6

Joke Haafkens

RITUALS OF SILENCE

Long-serm tranquilizer use by women in the Netherlands. A social case study

ISBN 90-5589-062-6

Michael Tan

GOOD MEDICINE

Pharmaceuticals and the Construction of Power and Knowledge in the Philippines ISBN 90-5589-07I-5

Marianne Potting VANJE FAMILIE.

Zorg, familie en sekse in de mantelzorg

ISBN 90-5589-203-3 


\title{
Ervaren Pioniers
}

\section{Omgaan met twijfel in de intensive care voor pasgeborenen}

\author{
PROEFSCHRIFT \\ ter verkrijging van de graad van doctor aan de Universiteit Maastricht, \\ op gezag van de Rector Magnificus, prof. dr. A.C. Nieuwenhuijzen Kruseman \\ volgens het besluit van het College van Decanen, \\ in het openbaar te verdedigen \\ op vrijdag 28 juni 2002 om 12 uur
}

door

Jessica Mesman

geboren op 2 april 1962 te Berkel en Rodenrijs 
tegemoet trad, heb ik als zeer bijzonder ervaren. Ondanks onze disciplinaire verschillen en de daarbij behorende methodologische gebruiken heb je mij zonder enige aarzeling toestemming verleend om de gebeurtenissen op je afdeling te onderzoeken. Ik mocht alles zien, horen en lezen. Deze openheid is van groot belang geweest voor mijn datacollectie en als zodanig voor het slagen van dit onderzoeksproject.

Dit brengt mij tot diegenen zonder wie dit proefschrift inhoudsloos zou zijn geweest: de artsen, verpleegkundigen en ouders op de beide afdelingen die ik mocht onderzoeken. Ik dank jullie allen voor het vertrouwen dat jullie mij gaven. Ik ben mij er terdege van bewust dat ik geen enkel recht had om jullie te bevragen, te bekijken en te beluisteren, maar dat ik dit alles mocht doen op basis van jullie gastvrijheid en goede wil. Jullie nimmer aflatende bereidwilligheid om met mij te praten over hetgeen zich voordeed, heb ik altijd zeer op prijs gesteld. Ik heb geprobeerd om integer met deze soms zeer persoonlijke informatie om te gaan. Ik hoop dat ik hierin ben geslaagd.

Het onderzoek in de Verenigde Staten zou niet mogelijk geweest zijn zonder de actieve inzet van Fred Frohock en Phil Swenders. Fred, met jouw voortreffelijke studie naar de 'special care' op een neonatologieafdeling heb jij mij op het spoor van dit specialisme gezet. Op jouw voorspraak mocht ook ik deze afdeling onderzoeken. Ik dank je daarvoor. Phil, jij was mijn 'patron' in het veld en die rol vervulde je met verve. Het was een genoegen om onder jouw hoede te mogen verkeren. Ik ben eveneens dank verschuldigd aan de Nederlandse Organisatie voor Wetenschappelijk Onderzoek (NWO) en de Stichting Wetenschappelijk Onderwijs Limburg (SWOL). De financiële steun daarvan heeft mijn verblijf in de Verenigde Staten mogelijk gemaakt.

Marc Berg en Peter Peters, mijn twee paranimfen, wat kan er misgaan met jullie aan mijn zijde. Marc, deze rol hadden we elkaar al toebedeeld toen we nog jong en onbezonnen als student over onze toekomst zaten te dromen. Ik ben blij dat ik nu mijn belofte kan inlossen. Beschouw het als een mooie bezegeling van een reeds lange vriendschap. Peter, onze dribbels zijn mij dierbaar en ik hoop er nog velen met je te maken. Terwijl we op en neer over de prachtige oude stadsmuren van Maastricht wandelden, namen we en passant de ups en downs van het leven van een promovendus door. Het deed me altijd goed en ik kijk uit naar ons beider post-promotiegedribbel.

In Saskia van der Lyke en Mark van der Hoeven vond ik twee trouwe meelezers en in Ton Brouwers een redacteur van formaat. Saskia, de precisie waarmee je mijn teksten analyseerde en de helderheid waarmee je ze becommentarieerde is voor mij zeer waardevol geweest. Daarnaast bood je kennis van de gezondheidszorg, en die van de verpleegkunde in het bijzonder, een kritische blik waar ik dankbaar gebruik van heb gemaakt. Aan onze gesprekken aan je keukentafel kijk ik met zeer veel genoegen terug. Mark, tussen de bedrijven door wist je altijd 
tijd te vinden om die 'dikke pakken tekst' van mij zorgvuldig te bestuderen en waar het nodig was te corrigeren. Je medische blik was voor mij een belangrijke toetssteen voor hetgeen ik beschreef. Door je grote gevoel voor humor en je eerlijke reflecties op je vakgebied heb ik onze gesprekken altijd als buitengewoon prettig ervaren. Ton, jouw taalvaardigheid is in grote mate verantwoordelijk voor de leesbaarheid van de tekst. De zinnen werden verzet of aangescherpt en zo wist je mijn tekst tot cen mooi vlociend geheel om te smeden. Onze samenwerking was zeer goed en heeft voor mij de laatste loodjes een stuk lichter gemaakt.

Een proefschrift schrijven in een academische setting biedt de luxe van een veelvoud aan platforms waarin 'work-in-progress' onder de loep genomen wordt. Zowel bij de onderzoeksschool Wetenschap en Techniek in de Moderne Cultuur (WTMC) als de onderzoeksgroep van Beraad Onderzoek Technick en Samenleving (BOTS) in de Faculteit der Cultururwetenschappen als die van Theorie, Onderzoek en Normativiteit (TON) in de Faculteit der Gezondheidswetenschappen heb ik altijd een zeer geïnteresseerd en zeer kritisch publiek gevonden. Een prachtige combinatic. Ik dank alle leden voor de opbouwende kritiek en hun inzet om met mij mee te denken. In het bijzonder dank ik Sjaak Koenis, René Gabriëls, Klasien Horstman en Bernike Pasveer. Jullie commentaar was zeer leerzaam voor mij. Daarnaast had ik het voorrecht om lid te mogen zijn van de oude en de jonge 'AlO-soep'. In het bijzonder wil ik Roland Bal, Antoinette de Bont, Michiel van Dorp, Ruud Hendriks, Loes Kater, Nel Knols, Agnes Meershoek, Irma van der Ploeg, Marianne Potting en Marie José Smits bedanken. Jullie commentaar was messcherp doch zeer constructief en deed mij opgewekt naar huis terugfietsen om de volgende dag vol goede moed het hele hoofdstuk weer om te gooien. De hoofdstukken werden er beter van en 'het hield mij van de straat'.

Mijn vrienden, jullie dank ik voor jullie steun en oprechte interesse in mijn wel en wee en de wordingsgeschiedenis van dit proefschrift in het bijzonder. Ik koester onze vriendschap en voel mij met jullie om mij heen een bevoorrecht mens. Velen van jullie heb ik reeds hierboven genoemd. Maar enkelen ook nog niet. Ik denk hierbij aan jou Ruth Benschop, Karin Bijsterveld, Tren Blom en Joke van Bokkum, José van Dijck, Wilma van Engen en Irene Glansbeek, Map en Mary van Es, Bernadette de Goey, Emilie Gomart, Harriet Kollen, Marloes Rikhof, Geert Somsen, Cecile aan de Stegge, Yolanda Tilly, Vivian Tinga, Ginette Verstraete en Sally Wyatt. Jullie weten het: mijn dank is groot.

Mijn familie dank ik voor hun geduldig ongeduld. Met jullie trouwe vraag of het proefschrift al haast af was, gaven jullie impliciet blijk van een rotsvast vertrouwen dat het ook daadwerkelijk af zou komen. Ik moet bekennen dat het even duurde voordat ik in jullie vraag dit vertrouwen weerspiegeld zag. Mam, Leo en Brigitta, nu is het dan zo ver en wat is er mooier dan dit samen met jullie en je gezin te mogen vieren. Zo zie je maar: eind goed, al goed. 



\section{Inhoudsopgave}

HOOFDSTUK I Neonatologie: een praktijk in beweging 1

Machines en moraal 2

Een routebeschrijving: doel en middel 5

HOOFDSTUK 2 Pasgeboren en onbepaald 13

Het definiëren van de situatie $\quad 13$

De constructie van kind en afdeling $\quad 18$

Het kind als constructie $\quad 18$

Identiteit als geordend complex $\quad 21$

De afdeling als constructie $\quad 24$

Wijzen van redeneren $\quad 26$

Het gebruik van repertoires $\quad 30$

HOOFDSTUK 3 Reisgenoten 35

Wederzijdse verwachtingen $\quad 37$

Verwachtingen van stafleden over de ouders 38

Verwachtingen van ouders over de staf 40

Wederzijdse beeldvorming $\quad 42$

De ouder als object van zorg $\quad 44$

De ouder als drager van ouderlijke macht 48

Het is de arts die beslist 50

Het zijn de ouders die beslissen $\quad 52$

Het is de wet die beslist 53

Rivaliserende vocabulaires? $\quad 56$

Wie beslist? $\quad 57$

Wanneer wordt er besloten? $\quad 60$

HOOFDSTUK 4 Een onzeker traject 63

De bepaling van het handelingstraject 65

Tijd als risico en als bondgenoot 65

Het gebruik van richtlijnen $\quad 68$

De rol van techniek op het handelingstraject $\quad 72$

Techniek en zorg 72

Disciplinering van de handelingspraktijk 75

Techniek als probleem $\quad 79$ 
Het getal als kompas $\quad 82$

Een betrouwbaar instrument $\quad 83$

De interpretatie van getallen $\quad 84$

Getal versus getal $\quad 86$

Rivaliserende kaders van kennis $\quad 88$

$\begin{array}{lll}\text { HOOFDSTUK s Bakens aan de horizon } & 91\end{array}$

Positie en prognose 93

De specificiteit van de blik 95

De specificiteit van het handelen $\quad 96$

Een topografie van ervaring $\quad 97$

Afstand en nabijheid $\quad 99$

Kijken en vergelijken $\quad 104$

Aanraken en afblijven $\quad 106$

Prognostische bakens $\quad 109$

Exemplarische kinderen $\quad 110$

De technologische bepakking 113

Ritme en tempo $\quad 117$

Het gebruik van ruimte $\quad 119$

Ervaring en verwachting $\quad 122$

HOOFDSTUK 6 De morele lading 125

De aard van de beslissing $\quad 127$

Evidentie $\quad 128$

Symmetrie $\quad 131$

De functionaliteit van de relokatie 133

Robuustheid 133

Draagviak 137

Een ander traject, een andere orde $\quad 141$

HOOFDSTUK 7 Het einde van de reis 149

Momenten van reflectie 149

De geschiedenis herschreven $\quad 153$

De situering van kennis en moraal $\quad 155$

Stijlen van ordenen $\quad 156$

Reflective practitioners $\quad 158$

Verklarende woordenlijst $\quad 161$

Noten 165

$\begin{array}{ll}\text { Literatuur } & 187\end{array}$

Summary 203

Curriculum Vitae $\quad 210$ 


\title{
Neonatologie: een praktijk in beweging
}

\begin{abstract}
Academisch Centrum
De deur klapt open. Een transportcouveuse rolt de NICU op met daarachter een verpleegkundige en een arts. In de couveuse ligt Tom tussen een wirwar van draden en slangen. Hij is nog geen kwartier oud. Vaardige handen leggen hem direct na binnenkomst in zijn eigen bed: een couveuse omringd door medische apparaten.
\end{abstract}

Beademd, gevoed en verwarmd: zo begint het leven van Tom. Hij is geboren na een zwangerschap van 26 weken en weegt 610 gram. Zijn gewicht staat in schril contrast met de 3500 gram van een voldragen kind van 40 weken. Klein en kwetsbaar wordt hij de neonatologieafdeling binnengereden. Zijn tweelingbroertje is direct na de bevalling overleden.

In Nederland worden ieder jaar 200.000 kinderen geboren, van wie er 40.000 in het ziekenhuis worden opgenomen en 4500 intensive care nodig hebben.' De afdeling Neonatologie is gespecialiseerd in de zorg en behandeling van deze pasgeborenen, ook wel neonaten* genoemd. Elk academisch ziekenhuis beschikt over een neonatologieafdeling met een medium care unit (MC), een high care unit (HC) en een intensive care unit (NICU). ${ }^{2}$ Op de medium care unit liggen kinderen die relatief weinig medische zorg nodig hebben. Ze zijn niet ernstig ziek geweest of al aan de beterende hand. Hier wordt vooral geslapen, gegeten en gegroeid. Op de high care unit liggen kinderen die niet (meer) in een levensbedreigende situatie verkeren, maar (nog) wel bijzondere zorg behoeven. Er wordt voortdurend met kinderen geschoven van NICU naar $\mathrm{HC}$, van $\mathrm{HC}$ naar $\mathrm{MC}$, en dan naar huis. Dit is het ideale traject voor elk kind dat op de NICU binnenkomt.

Op de NICU liggen kinderen die ernstig ziek zijn als gevolg van complicaties bij de bevalling, aangeboren afwijkingen, infecties of vroeggeboorte.' Rond hun couveuses staat een keur aan medische apparatuur opgesteld: monitoren met knipperende getallen en piepende alarmen die voortdurend de aandacht opeisen, beademingsapparaten die hun taak zuchtend en steunend uitvoeren, als ze geen geborrel of doordringend geratel laten horen. Slangen en draden gaan de couveuses in en verbinden de kinderen met de machines ernaast. De kinderen 
liggen doorgaans te slapen, de meeste onder invloed van kalmeringsmiddelen. Een enkeling huilt. Zonder geluid overigens, als gevolg van de tube van de beademingsslang in hun keel. De kwetsbaarheid van de kinderen maakt dat ze nauwlettend in de gaten moeten worden gehouden. Voortdurende bewaking en een nauwkeurig afgestemd beleid zijn voor hen van levensbelang. Daarom zijn er op de NICU vierentwintig uur per dag artsen en verpleegkundigen aanwezig. Het licht gaat hier nooit uit.

De NICU-praktijk is bijzonder om twee redenen: ten eerste beweegt zij zich aan het front van de medische wetenschap, en ten tweede roepen veel van de medische handelingen die er plaatsvinden ethische vragen op. Ondanks de talloze dilemma's die hieruit voortvloeien, en die uiteraard met elkaar verweven zijn, dienen de betrokkenen te voorkomen dat het handelingsproces vastloopt. Hoe doen zij dit? Hoe vindt het handelen op de NICU voortgang? Wat zijn de mechanismen die de continuĩteit van het medisch handelen waarborgen? Deze vragen staan centraal in deze studie en het is mij daarbij vooral te doen om de manier waarop voor de betrokkenen in de dagelijkse NICU-praktijk de onderlinge verhouding tussen feiten, waarden en handelen tot stand komt. Het gaat mij in dit boek niet om het geven van een visie op de juistheid van beslissingen, diagnoses of behandelingen, maar om een sociaal-wetenschappelijke beschouwing van de manier waarop keuzes worden gemaakt, gegevens worden geïnterpreteerd en problemen worden opgelost in situaties van grote onzekerheid, zoals die zich voordoen in het dagelijks leven op de NICU. Om deze problematiek beter te kunnen begrijpen ga ik eerst nader in op de bovengenoemde kenmerken van de neonatologieprakrijk: de voortdurende betrokkenheid op de meest geavanceerde medische kennis en technologie en de morele discussies die deze praktijk dientengevolge steeds weer oproept.

\section{Machines en moraal}

In 1880 bezocht Etienne Tanier, een Franse verloskundige, een landbouwtentoonstelling waar broedmachines voor kuikens gedemonstreerd werden. Dit bracht hem op het idee om een 'broedstoof voor premature kinderen te ontwikkelen. In de couveuse zou hun lichaamstemperatuur op peil gehouden kunnen worden. Het kind zou de laatste weken van de zwangerschap in deze kunstmatige baarmoeder verder groeien.

De introductie van de couveuse aan het eind van de negentiende eeuw betekende het begin van de speciale behandeling van pasgeborenen die zich heeft ontwikkeld tot de hedendaagse neonatologiepraktijk, waarin ultramoderne apparatuur en optimale zorgfaciliteiten centraal staan. Vooral in de periode na de Tweede Wereldoorlog heeft de ontwikkeling van medische technologie een 
enorme vlucht genomen. De opening van de eerste intensive care units voor pasgeborenen in de jaren zestig betekende een radicale verschuiving van de grens tussen wie wel en wie niet als levensvatbaar werd gekwalificeerd en derhalve wel of niet voor behandeling in aanmerking kwam. ' Het overlevingspercentage van pasgeborenen nam in deze periode sterk toe.' Zo lag in de jaren vijftig de ondergrens voor behandeling bij een geboortegewicht van 1500 gram. Tegenwoordig geldt een geboortegewicht van rond de 500 gram en/of 25 weken zwangerschapsduur als ondergrens. Aan het begin van de twintigste eeuw had een kind met een geboortegewicht onder de 1000 gram geen enkele overlevingskans, terwijl kinderen met een geboortegewicht tussen de 1000 en 1500 gram $\mathrm{n} \%$ kans op overleving hadden. Met de intensieve zorg die op de NICU verleend kon worden steeg dit percentage in de cerste helft van de jaren zeventig naar respectievelijk $33 \%$ en $68 \%$. In de jaren tachtig nam dit percentage nog verder toe naar respectievelijk $46 \%$ en $82 \%$." Hierbij zijn met name ontwikkelingen op het gebied van kunstmatige beademing, zoals CPAP* en de toepassing van Surfactant", van groot belang geweest. 'Het succes van de behandeling van prematuriteit heeft ertoe geleid dat in de jaren negentig kinderen met een geboortegewicht van minimaal 1000 gram na een zwangerschap van meer dan 26 weken een overlevingskans van $90 \%$ hadden.' In eerste instantic ging deze stijging gepaard met een toename van het aantal kinderen met handicaps, zoals blindheid, spasticiteit en een geringer verstandelijk vermogen.' Door verfijning van de apparatuur en een toename van de kennis en vaardigheden ging dit percentage in de jaren zeventig weer omlaag. ${ }^{10}$ Vanaf de jaren tachtig groeide het besef dat zwangerschap, geboorte en de neonatale fase niet los van elkaar mogen worden gezien. Vanuit dit perspectief ontstond er een intensieve samenwerking tussen gynaecologie, verloskunde en neonatologie, die inmiddels is uitgegroeid tot het vakgebied perinatologie*.

Hoewel de neonatologie zich kon beroepen op vele medische successen, ontstond er eind jaren zeventig een publieke discussie over de ethische aspecten van deze praktijk. Op basis van geavanceerde technologie hebben artsen nieuwe behandelingsmogelijkheden ontwikkeld, maar voor buitenstaanders bleek de dominante rol van technologie in deze ontwikkeling ook een reden tot zorg. Volgens sommigen werden de ontwikkelingen in de neonatologiepraktijk gedicteerd door een technologisch imperatief: alles wat technisch mogelijk is, wordt ook ingezet. Ook binnen de professie zelf is bezorgdheid geuit. Versluys, hoogleraar Neonatologie, betoogde in 1987:

'Wij behandelen steeds kleinere pasgeborenen; 32 weken zwangerschapsduur, ooit zo ongeveer de limiet, werd 30, 28, 26...weken. Koesteren wij straks misschien een 12-weker aan een kunstmatige placenta, samen met de collega embryoloog en de embryologisch geschoolde verpleegkundige? Of verder tot aan het voederen van de laatste zaadcel toe? 
Wij zetten daartoe steeds geavanceerder middelen in. Onze intensive care units voor pasgeborenen werden machinekamers met zoekplaatjes: waar is het kind? $\mathrm{Na}$ ampel zocken ontwaart u roze leven beademd via een endotracheaal tubetje van $2,5 \mathrm{~mm}$ doorsnee, in de bloedvatencanules van nog tien maal zo klein, bevloeid door elektronisch-pientere pompjes: de pneumothorax wederzijds gedraineerd, bloedige bloeddrukmeting via een arteria-radialiscatheter, zuurstofmeting percutaan. Noem het, het zit erop of eraan in minimaat en als het er nog niet is, komt het binnenkort."

$\mathrm{Na}$ deze opsomming plaatste Versluys kritische kanttekeningen bij dit 'triomfantelijk vooruitgangsgeloof. Met de techniek hadden artsen dan wel een machtig middel in handen, maar het zou ook morele dilemma's met zich meebrengen. Op welke wijze moest men deze oplossen en wie mocht daarover beslissen? De boodschap van Versluys stond niet op zichzelf. Steeds vaker klonk de vraag: 'mag en moet alles wat kan?" ${ }^{\prime \prime}$ Gezien de ernst van aan vroeggeboorte gerelateerde handicaps leek niet elk kind gebaat bij levensreddende interventies. De traditionele gelijkschakeling tussen 'al het mogelijke doen' en 'goed doen' was volgens sommigen niet langer houdbaar en dit betekende dat de inzet van technologie hiermee haar vanzelfsprekendheid verloor. "In bepaalde gevallen zou het nalaten of stoppen van een behandeling de voorkeur verdienen op grond van de te verwachten kwaliteit van leven.

Steeds meer artsen kozen voor een selectief behandelingsbeleid. ${ }^{4}$ De kinderen die niet voor behandeling in aanmerking kwamen, stierven vrijwel direct. Hiermee rees de vraag in welke gevallen het nalaten van behandelen dan wel geoorloofd was en wie hierover mocht beslissen. De discussie ging niet meer alleen over grenzen voor levensverlengend handelen, maar ook - en zelfs meerover die voor levensbeëindigend handelen." Vanwege de ernst van dergelijke beslissingen reikte de discussie over levensbeëindigend handelen verder dan de werkvloer. Een groeiend aantal ethici en juristen gaf eveneens hun visie op de grenzen van de geneeskunde, levensbeèindigend handelen in het bijzonder. ${ }^{.6}$ Artsenorganisaties zagen zich genoodzaakt expliciet stelling te nemen. Er verschenen rapporten met inhoudelijke en procedurele richtlijnen. " Deze aandacht voor richtlijnen kwam voort uit het verlangen grip te krijgen op de complexe morele problemen dic zich in de praktijk voordoen; de richtlijnen zouden als een mal fungeren waarin ethische vragen tot hanteerbare proporties teruggebracht konden worden. Bovendien kwamen de richtlijnen tegemoet aan een behoefte tot regulering. Duidelijk omschreven procedures zouden er toe bijdragen dat beslissingen over levensbeëindigend handelen op een zorgvuldige wijze werden genomen."

Het spreekt voor zich dat de neonatologiepraktijk niet als enige met complexe vraagstukken worstelt; dit is immers kenmerkend voor de gehele hedendaagse 
geneeskunde. Net zo min fungeert de procedurele richtlijn als een oplossing die specifiek is voor de ethische problematick van de neonatologiepraktijk. Inhoudelijke en procedurele richtlijnen komen ook voor op andere terreinen van de gezondheidszorg." Een dergelijke benadering is echter binnen de geneeskunde en de ethiek van meet af aan onderwerp van kritick geweest. ${ }^{.0}$ Algemene richtlijnen en procedures zouden voorbij gaan aan de concrete situatic, de ervaringswereld van de betrokkenen en het complexe, unieke karakter van de medische praktijk. Om hieraan recht te doen, aldus de critici, is reflectie van binnenuit noodzakelijk. Dit vereist een ethiek die het bijzondere karakter van de situatie niet negeert, maar haar juist tot uitgangspunt neemt. Geen universele principes, maar een gesitueerde moraal dient het brandpunt van aandacht te zijn."

De discussie over de gezondheidsethiek - de procedurele aanpak in het bijzonder - wordt voornamelijk binnen de muren van de academische wereld gevoerd. Het debat over de inzet van medische technologie en de beslissingsmacht van artsen speelt zich echter ook in het publieke domein af. Ook 'buitenstaanders' houden zich bezig met de beslissingen die op de werkvloer genomen worden. Zo staan medisch-technologische ontwikkelingen ook op de agenda van publieke fora en zijn er commissies die het medisch handelen regelmatig toetsen. De tijd dat het handelen van artsen enkel binnen eigen kring wordt verantwoord, lijkt hiermee ten einde.

\section{Een routebeschrijving: doel en middel}

Ondanks de vele discussies over de medische praktijk is er nog weinig zicht op wat zich op de werkvloer zelf afspeelt. De snelle medisch-technologische ontwikkeling van de afgelopen decennia biedt ongekende handelingsmogelijkheden, maar genereert ook nieuwe beslismomenten en dilemma's voor de betrokkenen. Er is een grijs gebied ontstaan, waarin de conventionele antwoorden in handboeken en adviezen van richtlijnen niet meer voldoen. Toch vereisen veel medische gevallen dat er direct wordt ingegrepen. Behalve de ontwikkeling van pragmatische richtlijnen is het van belang op een andere wijze na te denken over de complexe problemen van onze hoogtechnologische gezondheidszorg. Hierbij verdient met name het dagelijks handelen in de praktijk meer kritische aandacht. Meer dan kwantitatieve analyses kunnen kwalitatieve studies leiden tot een diep en veelzijdig inzicht in de steeds grotere verwevenheid van problemen en dilemma's in de hedendaagse medische handelingspraktijk. "Een vooruitgeschoven post als de NICU fungeert daarbinnen als een exemplarisch voorbeeld van een praktijk in beweging.

Deze studie richt zich op een beschrijving en analyse van de diverse vraagstukken in de dagelijkse NICU-praktijk met zijn hightech apparaten, hoogopge- 
leide verpleegkundigen en neonatologen, hoopvolle maar ook angstige ouders en de kwersbare kinderen om wie alles draait. Hoe komt men tot diagnoses? Hoe gaat men om met de grote onzekerheid die onvermijdelijk met dit front van wetenschappelijke geneeskunde is verbonden? Wat is de inbreng van de verschillende betrokkenen? Welke rol speelt de medische technologie? Hoe worden beslissingen genomen? Ik zal vooral de bijzondere dynamiek van de NICU-praktijk belichten: de rollen van mensen, de betekenissen van gegevens, de functies van apparaten - alles op de NICU bestaat in een permanente dynamiek van verandering.

Om de diverse processen op de NICU in hun onderlinge verband te kunnen onderzoeken, is een perspectief van binnenuit noodzakelijk. De methode van participerende observatie is bij uitstek geschikt om de dynamiek van de medische praktijk in situ te onderzoeken. Participerend observerend onderzoek kenmerkt zich door het feit dat de onderzoeker zelf voor enige tijd deel uitmaakt van de setting die wordt onderzocht." Tijdens dit veldwerk observeert de onderzoeker het doen en laten van de groep, luistert naar wat er wordt gezegd en stelt vragen over wat er gebeurt. "Zo bestudeer ik in deze studie primair de visie en ervaringen van de betrokken artsen, verpleegkundigen en ouders. Waaraan ontlenen zij houvast in deze complexe praktijk? Welke middelen zetten zij in om het handelingsproces vlot te trekken als dat is vastgelopen? Onderzoek naar antwoorden op deze vragen kan de veelal impliciete patronen zichtbaar maken die worden ingezet om de behandeling van de pasgeborene tot een goed einde te brengen. Een gedetailleerde studie van strategieën waarmee men op de NICU de dagelijkse problemen te lijf gaat door middel van de methode van participerende observatie verschaft inzicht in het proces waarin een behandelingstraject haar invulling krijgt en tegelijkertijd de sociale orde wordt gehandhaafd. Welke manieren van redeneren, spreken en handelen worden er op de NICU gebruikt om problemen te identificeren, te voorkomen of op te lossen? Voor de beschrijving van deze processen maak ik gebruik van analytische categorieën zoals 'repertoire', 'vocabulaire' en 'script'. Deze onderzoekercategorieën (tweede orde) maken zelf dus geen deel uit van de taal die de betrokkenen op de NICU (eerste orde) hanteren.

Meestal maakt een NICU een goed geordende indruk, weet men wat men te doen heeft en worden de kinderen op geroutineerde wijze behandeld en verzorgd. Maar de schijn bedriegt: de sociale orde moet voortdurend worden 'gemaakt' en bijgesteld omdat bij de behandeling van ernstig zieke, instabiele pasgeborenen de bestaande routines en vanzelfsprekendheden niet altijd toereikend zijn om nieuwe en onverwachte situaties her hoofd te bieden. Om de veelal impliciete methodes en strategieèn van de betrokkenen op de NICU in beeld te krijgen, bleek het methodisch vruchtbaar om de aandacht te richten op het 'grijze gebied' - de gevallen en situaties waarin niet precies duidelijk is wat er 
aan de hand is en wat er gedaan moet worden. Door de mocilijke gevallen en situaties op de voorgrond te plaatsen komen de grenzen en dilemma's van interventie scherper in beeld. De nadruk op 'hard cases', fricties en verstoringen dient dus een methodologisch doel. Het is dus niet omdat deze gevallen vaak voorkomen, maar omdat daar een theoretische reden voor is: ze leren ons meer over de aard van het zorgvuldig pionieren. Het gaat er dus niet om de indruk te wekken dat de normale situatic op een NICU er een is van voortdurende onmacht, onzekerheid en rwijfel. Sociale conventies en dagelijkse routines zijn vormen van handelingscoördinatie die doorgaans krachtig genoeg zijn om een 'normale gang van zaken' te creëren en te bestendigen. In de meeste gevallen is een behandeling succesvol en is het duidelijk wat er gedaan moet worden en wie welke taken en verantwoordelijkheden heeft. Maar, zo zal ik laten zien, deze 'gewone', alledaagse praktijk is het resultaat van een actief ordeningsproces en leidt op de NICU een kwetsbaar bestaan. Hier liggen immers de kinderen die nier altijd volgens de boeken op medische interventies reageren of voor wie zelfs nog geen normaalwaarden bestaan. Bovendien moeten beslissingen hier vaak in een zeer kort tijdsbestek genomen worden, waarbij feitelijke gegevens ontbreken of dubbelzinnig zijn en normen en waarden de neiging hebben hun vanzelfsprekendheid te verliezen. ${ }^{2}$ Op dergelijke momenten stokt het handelingsproces en in het ergste geval loopt het vast. De noodzakelijke aanpassingen en herstelwerkzaamheden bieden inzicht in de manier waarop in de NICU-praktijk keuzes worden gemaakt en grenzen eventueel worden verlegd.

Aandacht voor 'geneeskunde-in-actie' is niet alleen een beproefd middel in de medische antropologie en de medische sociologie, maar ook in het wetenschaps- en techniekonderzoek. ${ }^{16}$ Het is deze laatste traditic waarbij ik in deze studie aansluiting zoek. Het wetenschaps- en techniekonderzoek bekritiseert onder meer het beeld dat de onderliggende structuur van het (medisch) handelen wordt gevormd door (medische) principes, deductieve denkpatronen en besluitvormingsprotocollen. Onderzoek in diverse praktijken heeft geen enkele grond voor deze veronderstelling gevonden. Gedetailleerde studies laten zien dat praktisch handelen niet teruggebracht kan worden tot het louter toepassen

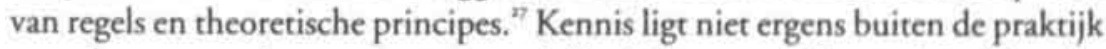
gereed om te worden toegepast, maar krijgt juist vorm in het praktisch handelen. Het veldonderzoek waarop deze studie is gebaseerd, legt dan ook niet zozeer nadruk op medische en ethische handboeken, voorschriften en beroepscodes, maar op de dagelijkse handelingspraktijk van de NICU.

Hoewel in elk hoofdstuk ethische kwesties op directe of indirecte wijze aan bod komen, zou ik deze studie niet als een normatieve etnografie willen kwalifi-

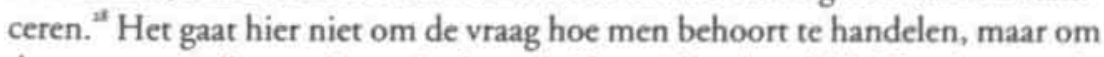
de vraag op welke manier er in de praktijk wordt gehandeld. Hier is evenmin aan de orde of men op de NICU wel de richtlijnen volgt, noch gaat het om een 
evaluatie van de bestaande richtlijnen en procedures. Deze studie moet dan ook niet zozeer gelezen worden als een onderbouwing van een positionering in het ethisch debat. De inzet is een andere. Dit onderzoek ambieert een ander perspectief op de NICU te bieden door deze praktijk langs andere assen open te leggen. Dit wil niet zeggen dat dit onderzoek geen inzichten oplevert die interessant kunnen zijn voor de neonatologiepraktijk zelf en de ethiek van de gezondheidszorg." I $k$ hoop dat de beschrijvingen en analyses die ik in dit boek naar voren breng, een bijdrage leveren aan reflecties op de NICU en de ethische dilemma's die zich daar voordoen. Deze kwestie komt echter pas in hoofdstuk zes expliciet aan bod. Daar zal ik laten zien hoe gevalsbeschrijvingen consequenties hebben voor de wijze waarop morele vraagstukken op de NICU worden opgelost.

Het veldwerk voor deze studie is verricht in de jaren negentig op twee verschillende neonatologische intensive care units: de NICU van het 'Academisch Centrum' in Nederland en de NICU van het 'Northeastern General Hospital' in de Verenigde Staten. Omwille van de privacy zijn de beschreven gevallen en de betrokkenen geanonimiseerd. Het Academisch Centrum verwijst naar één var de acht academische ziekenhuizen die Nederland telt. Vier maanden lang wa: ik daar haast dagelijks op de Neonatologieafdeling te vinden. Deze afdeling̨ biedr nlaats aan vierentwintig kinderen. waarvan er negen op de NICU kunner liggen. Zij komen voornamelijk uit de regio; alleen bij plaatsgebrek op een van de andere tien NICU's worden hier ook kinderen van elders opgenomen. De neonatologen dragen de verantwoordelijkheid voor de behandeling van de kinderen op de afdeling. De verantwoordelijkheid voor de concrete uitvoering van de behandeling valt onder de dienstdoende neonatoloog, de 'attending'. Elke maand neemt een van de neonatologen deze taak op zich. Belangrijke of ingewikkelde beslissingen worden echter altijd in overleg met de andere neonatologen genomen. Daarnaast wordt elke donderdag tijdens de grote visite de behandeling van de kinderen door de hele medische staf besproken. De medische staf bestaat naast neonatologen ook uit arts-assistenten en andere betrokken specialisten, zoals een kinderneuroloog, kindercardioloog of bacterioloog. De op deze afdeling werkzame verpleegkundigen zijn gespecialiseerd in neonatologie. De neonatologen en verpleegkundigen behoren tot de vaste staf van de afdeling. Arts-assistenten zijn tijdelijke krachten. Tijdens hun opleiding tot kinderarts doen zij ervaring op in verschillende terreinen van de kindergeneeskunde. Neonatologie is er daar een van. Onder de hoede van de attending voeren zij de behandeling van de kinderen uit.

De NICU van het Northeastern General Hospital, waar ik gedurende twee maanden veldonderzoek heb gedaan, is groter dan die van het Academisch Centrum. Het heeft een opnamecapaciteit van veertig plaatsen. Bij plaatsgebrek worden de couveuses een beetje dichter bij elkaar gezet zodat er plaats is voor een extra opname. Door de grote omvang is de intensive care unit hier 
een afdeling op zich. Het verzorgingsgebied van de NICU in het Northeastern is drie keer zo groot als dat van het Academisch Centrum. In het Northeastern worden kinderen geregeld met een vliegtuig of helikopter voor behandeling ingevlogen. Net als in het Academisch Centrum neemt in het Northeastern elke maand een andere neonatoloog de rol van attending op zich. Anders dan in het Academisch Centrum draagt hier niet het behandelteam, maar de attending de volledige eindverantwoordelijkheid. Er is wel overleg met collega's, maar dit is eerder uitzondering dan regel. Er is dan ook niet zozeer sprake van een afdelingsbeleid, zoals in het Academisch Centrum, maar van een wisselend, persoonsgebonden medisch beleid. Dit kan soms tot verwarring leiden bij de arts-assistenten wanneer een andere neonatoloog attending wordt. Behandelingen kunnen dan opeens worden omgegooid omdat de nieuwe attending zich op andere theoretische inzichten baseert. Anders dan in het Academisch Centrum komen veel arts-assistenten ('residents') uit het buitenland. Dit levert in een enkel geval communicatieproblemen op, iets waar vooral de verpleging tegenaan loopt. Ook de verpleegkundige staf laat een ander beeld zien. In het Northeastern bestaat de verpleegkundige staf vrijwel geheel uit vrouwen. Zij draaien vaste diensten: altijd dagdienst of altijd nachtdienst. Sommigen draaien al meer dan twintig jaar nachtdiensten. Naast de staf heeft ook de pariènten-

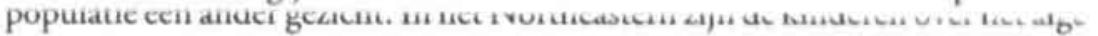
meen kleiner en zieker. Prematuren geboren na een zwangerschap van vierentwintig weken zijn geen uitzondering. Er liggen hier ook kinderen met zeer zware misvormingen en aandoeningen. In sommige gevallen zou prenatale hulp tot een positieve uitkomst hebben geleid, maar niet iedere ouder maakt gebruik van prenatale hulp. Een opvallend groot aantal van de ouders is jong en komt uit de laagste sociale klasse: tienerouders van veertien of vijftien jaar, verslaafde moeders en in een enkel geval ouders die niet kunnen lezen of schrijven.

Er bestaan dus opvallende verschillen tussen de NICU van het Academisch Centrum en die van het Northeastern General Hospital waar het de pasgeborenen, de ouders en het personeel betreft. Dit geldt niet voor de materiële omgeving. De couveuses in het Northeastern zijn omringd door dezelfde hoogwaardige apparatuur als die in het Academisch Centrum. Een gedeelde technologie betekent echter nog geen gedeelde cultuur en een cross-cultural onderzoek lijkt dan misschien voor de hand te liggen. Het is evenwel niet mijn intentie om een vergelijking tussen de situatie op de NICU in Nederland en de Verenigde Staten te maken. ${ }^{\circ}$ Veeleer dient het internationale karakter van mijn veldonderzoek een methodologisch doel: het verminderen van 'culturele blindheid'. Op de Nederlandse NICU zijn bepaalde aspecten zo 'gewoon' dat ze in eerste instantie als vanzelfsprekendheden overkomen en dus niet opvallen. In deze studie staat de NICU van het Academisch Centrum dan ook centraal en vervult de Amerikaanse NICU een ondergeschikte rol." Het veldonderzoek in de Verenigde 
Staten dient voornamelijk als contrast. Gebeurtenissen in het Northeastern General Hospital breng ik alleen in wanneer zij door hun contrastwerking complexe situaties die zich op de Nederlandse NICU voordoen, uitvergroten en dus verhelderen."

Het onderzoeksmateriaal is gebaseerd op participerende observatie, aangevuld door materiaal ontleend aan interviews met stafleden met diverse disciplinaire achtergronden." Ook heb ik dankbaar gebruik gemaakt van de inzichten die zijn opgedaan in andere studies van de neonatologiepraktijk." Mijn eigen veldmateriaal vormt echter de basis voor mijn analyse." De verzameling van dit materiaal vergt een grote mate van betrokkenheid, terwijl reflectie juist een zekere distantie vraagt. De emotionaliteit van bepaalde gebeurtenissen maakte het niet altijd eenvoudig om de nodige afstand in acht te nemen." Anonimisering, de toepassing van een eigen conceptueel kader en het gebruik van de tegenwoordige tijd en 'passive voice' dragen bij aan een zekere distantic en objectivering." Belangrijker dan deze methodologische middelen is echter de factor tijd - tijd om indrukken te laten bezinken en de soms zeer emotionele situaties in onderzoeksgegevens te vertalen.

Als kader voor mijn beschrijving en analyse van de neonatologiepraktijk maak ik gebruik van de reismetafoor. De behandeling van kinderen op een NICU is vanaf de eerste minuut als een reis waarvan de afloop niet vast staat en de te volgen route niet altijd even makkelijk is. Al heeft de staf een vergelijkbare reis reeds vele malen gemaakt, het traject en de omstandigheden zijn telkens verschillend. Kleine koerswijzigingen hebben grote, soms zelfs fatale gevolgen, maar in de meeste gevallen doemt wel weer een baken aan de horizon op, dat houvast biedt. De reisgenoten zijn in de eerste instantie vreemden voor elkaar: dit geldt voor ouders en staf, maar bovenal voor de pasgeborene zelf, de meest onbekende vreemdeling van allemaal. Ook het vertrekpunt van de reis moet nog duidelijk vastgesteld worden. Wat is er precies aan de hand met het kind?

Met de geboorte van het kind dient zich direct de eerste vraag aan: wie is dit kind? Het pasgeboren kind is nog onbepaald. Het tweede hoofdstuk beschrijft de wijze waarop de identiteit van de pasgeborene vorm aanneemt als de uitkomst van een stroom aan medische en verpleegkundige activiteiten en beslissingen. Dit proces geeft tevens een beeld van de NICU als praktische orde. Met de behandeling van het kind komen ook de ouders de afdeling binnen. Via het kind zijn ouders en staf onlosmakelijk met elkaar verbonden. Als reisgenoten maken zij deel uit van dezelfde situatie. Het derde hoofdstuk richt zich op de wijze waarop de sociale verbanden in de NICU geregeld zijn. De dynamiek van de NICU-praktijk wordt niet alleen bepaald door de voortgaande stroom activiteiten, nieuwe gevallen en 'nieuwe' ouders, maar ook door aanhoudende veranderingen in de situatie van het kind. Dit vereist constante bewaking en voortdurende aanpassingen. Het vierde hoofdstuk beschrijft het vaak moeizame traject dat de 
betrokkenen moeten volgen in de behandeling van een kind; her laat zien hoe met een behandeling niet zozeer een probleem wordt opgelost, maar een onzeker traject wordt geopend. Naarmate de tijd vordert neemt de handelingsruimte van de staf af en zal zij om het kind op de juiste koers te houden haar weg moeten zoeken in een groeiend aantal op elkaar inwerkende interventies. In ieders specifieke bemoeienis met het kind ontstaat een beeld van de prognose. In het vijfde hoofdstuk analyseer ik hoe verschillende referentiepunten als prognostische bakens fungeren. De complexiteit van de behandeling van de kinderen die op de NICU verblijven, kan ertoe leiden dat artsen, verpleegkundigen en ouders voor extreme morele dilemma's worden geplaatst. Elke behandeling draagt een morele lading, die in sommige situaties tot radicale keuzes noopt. Het zesde hoofdstuk analyseert op welke wijze de betrokkenen het morele omslagpunt bepalen. Aan bet einde van de reis kijkt men doorgaans nog even achterom, om verder te kunnen gaan. Men vangt weer een nieuwe reis aan, ervaren, maar het blijft pionieren.

Maar laat ik bij het begin beginnen en dat ligt voor de NICU-staf veelal voor de geboorte van een kind. Hoe bepalen de stafleden bij de aanvang van de reis wat de mogelijkheden en kansen voor behandeling zijn? 



\section{Pasgeboren en onbepaald}

\section{Academisch Centrum}

Het is zondag en in de verloskamer van het academisch ziekenhuis ligt een vrouw die, hoewel nog nauwelijks zichtbaar, zes maanden zwanger is van haar eerste kind. Een ernstige zwangerschapsvergiftiging " maakt voortzerting van de zwangerschap buitengewoon gevaarlijk. Rond haar bed staan haar man, een gynaecoloog, een neonatoloog en een verpleegkundige. ledereen in de kamer kijkt naar het CTG-apparaat" dat de hartslag van het kind op een monitor weergeeft. De hartfrequentie zakt regelmatig naar beneden. Het kind is onmiskenbaar in nood. Dan klinkt een luide pieptoon uit het CTG-apparaat. Als de interrupties elkaar sneller opvolgen en het steeds langer duurt voordat de hartslag zich weer herstelt, kan er een moment komen dat het hart zich niet meer zal kunnen corrigeren. Direct ingrijpen is vereist. Het kind moet zo snel mogelijk gehaald worden. De conditie van dit kind is echter zo slecht dat de kans op een goede afloop uiterst klein is.

Wat te doen? Hoe moet de situatie van het kind gedefinieerd worden? De keuze voor een behandeling staat immers niet los van de situatie waarop zij betrekking heeft. Dit dilemma dringt zich onmiddellijk op aan de aanwezigen in de verloskamer.

\section{Het definiëren van de situatie}

In de verloskamer moet worden gekozen tussen ingrijpen of laten sterven. Een keuze ligt niet direct voor de hand: het kind is in een slechte conditie, maar lijkt niet geheel kansloos. Hoe vormen de artsen en de ouders zich een beeld van de situatie en hoe bepaalt dat hun keuze?

De problematiek van het kind in het zojuist geschetste geval staat niet op zichzelf, maar maakt deel uit van de situatie van de moeder. Haar zwangerschapsvergiftiging* kan op verschillende manieren worden behandeld: met behulp van medicijnen of door de zwangerschap te beëindigen. Een medicamenteuze behandeling van een zwangerschapsvergiftiging impliceert dat alleen de moeder wordt behandeld, terwijl het kind als gevolg van de slechte conditie 
zal overlijden. Kiest men voor het beëindigen van de zwangerschap, dan wordt het kind via een keizersnede 'gehaald' en direct voor behandeling naar de NICU overgebracht. Bij een zwakke foetale conditie van het kind is de kans op overleving echter klein, wat de vraag doet rijzen of deze kans opweegt tegen de risico's voor de moeder die vastzitten aan cen operatieve bevalling. Juist het feit dat de keuze van de behandeling van de moeder én die van het kind in één en dezelfde beslissing besloten ligt, compliceert de situatie in de verloskamer.

In dit geval wijst alles in de richting van de noodzaak het kind direct te halen. Het CTG-apparaat geeft aan dat het zonder ingrijpen van buitenaf amper een uur te leven heeft. De aanwezige neonatoloog beaamt dit, maar hij wijst ook op de consequenties van deze beslissing voor het kind en de moeder:

\section{Academisch Centrum}

'We moeten niet vergeten dat dit kind nog maar vijfentwintig weken oud is en bovendien een ernstige groeiachterstand heef. Het is dus niet alleen veel te jong maar ook veel te klein."

Door de korte zwangerschapsduur, in combinatie met de groeiachterstand van het kind en de zorgelijke intra-uteriene conditie*, is de kans groot dat de verloskundige operatie 'slechts' een overgangsmoment markeert, waarin de 'foetale nood' wordt omgezet in 'neonatale nood' of zelfs 'neonatale dood'. De vader vraagt vervolgens naar de kansen van het kind, waarop de neonatoloog antwoordt:

\section{Academisch Centrum}

'Dat is op basis van wat we nu van het kind weten heel moeilijk te zeggen. Maar grof gezegd schat ik dat het er goed doorheen komt op 10\%, dat het blijft leven maar dan wel met ernstige handicaps ook op $10 \%$ en $80 \%$ dat het direct na de geboorte overlijdt. Maar nogmaals, het is een grove schatting.'

De hier genoemde percentages zijn allesbehalve precies. Maar zelfs als het zou gaan om nauwkeurige percentages, wat weten de aanwezigen in de verloskamer dan meer?

In deze fase van het leven van een kind is statistiek een van de weinige middelen om de overlevingskansen van een kind te bepalen. Deze worden afgeleid uit tabellen die zijn opgesteld naar zwangerschapsweken en gewicht. De conditie van een kind verandert sterk tijdens de zwangerschap. Een verschil van slechts enkele dagen heeft al effect op de overlevingskansen. Die nemen met drie tot vier procent per dag toe bij een zwangerschapsduur van 23 tot 24 weken. Bij een zwangerschapsduur van 24 tot 26 weken is dit twee tot drie procent per dag. Bovendien leidt een klein verschil in gewicht ook tot een aanzienlijk verschil in percentages. Als een kind na de geboorte iets meer of minder weegt dan op voorhand werd aangenomen, veranderen ook de overlevingskansen. Dit maakt 
een antwoord op de vraag van ouders naar overlevingskansen erg moeilijk. Artsen erkennen het problematische karakter van dergelijke voorspellingen. Een neonatoloog uit het Academisch Centrum zegt hicrover:

'Wij zijn ons van dit probleem bewust. De ene arts omzeilt daarom het noemen van concrete percentages. Een ander zegt 'vijftig procent kans dat het kind het haalt of niet' en zegt dus eigenlijk niets. Weer een ander maakt cen schatting. Het zijn dan ook veelal de ouders die percentages willen horen."

In de geschetste situatic in de verloskamer is weinig zekerheid al voldoende. Hoewel de genoemde getallen niet precies zijn, blijken ze van doorslaggevend belang voor de keuze van de vader:

\section{Academisch Centrum}

'Er is dus een kans dat her kind het haalt?', vraagt hij. De neonatoloog knikt en wijst op het feit dat als de conditie van het kind erg slecht wordt altijd de mogelijkheid bestaat de ingezette behandeling alsnog te staken. "Het is dus de keuze tussen een risico nemen en een kans geven of geen risico nemen en een kans ontnemen', concludeert de vader. 'Ik vind dat we ons kind deze kans moeten geven. Maar ik wil niet dat het kind een zwaar gehandicapt leven tegemoet gaat.'

Voor de vader is louter de aanwezigheid van een kans op overleving bepalend om voor ingrijpen te kiezen. Zijn kind is voor hem 'een kind met een kans'. Van deze kennis lijkt een moreel appèl uit te gaan: als er een kans is moeten we ingrijpen.

Dit handelingsgebod geldt niet alleen voor hoopvolle ouders; ook voor neonatologen kan de aanwezigheid van een geringe overlevingskans beslissend zijn. In het Northeastern General Hospital in de Verenigde Staten is het de morele plicht van iedere arts om elke kans aan te grijpen. De dominantie van deze regel in dit ziekenhuis blijkt bijvoorbeeld uit de behandeling van de prematuur geboren Maureen. Hoewel de zwangerschapsduur onder de limiet van vierentwintig weken lag en zij formeel dus niet voor een behandeling in aanmerking kwam, heeft dit de artsen er niet van weerhouden om na de geboorte van Maureen direct in te grijpen. De behandelend neonatoloog in het Northeastern General Hospital geeft hierop het volgende commentaar:

'Tja, zo'n grens van 24 weken moet je niet zo scherp zien. Het is 24 weken en
alles er omheen. Dit kind was 570 gram. Dus zo strak moet je die grenzen niet
trekken. Bovendien moesten we dit kind wel behandelen want het kwam er
levend uit. En het reageerde op de behandeling. De kans op overleven is voor een
23 -weker $20 \%$. Dus dat is niet zoveel. Maar voor een 24 -weker is het alweer $50 \%$.
Dus die doen we altijd. Bij een baby van 22 weken doen we niets. Daar beginnen
we niet eens aan. Maar als een 23 -weker er goed uit komt, wagen we een poging.' 
Het nalaten of staken van een behandeling is in het Northeastern alleen aan de orde wanneer er zekerheid bestaat over de afwezigheid van een kans op overleving. Een van de nurse practitioners" van de NICU in het Northeastern geeft de consequenties aan van het streven naar zekerheid:

'De beslissing om niet in te grijpen, wordt alleen genomen in die gevallen waarvan voor iedereen duidelijk is dat er helemaal niets meer te doen valt. Maar dit soort duidelijkheid is zeldzaam. In de meeste gevallen is het niet zeker en grijp je dus in. Op zo'n moment zet ik alles op alles.

Soms weet je niet goed waar je op af moet gaan. Ik heb wel eens een kind behandeld dat hele slechte bloedwaarden had. Volgens de boeken zou het kind het dus heel slecht moeten doen. Maar her deed het prima, terwijl kinderen met betere bloedwaarden er aan onderdoor gingen. Zo zie je, zelfs de medische kennis staat niet vast. Het is veeleer een interactie tussen jouw handelingen en de reactie van de baby. Je kennis is hierbij een hulpmiddel. Het is niet het enige waar je van uit kunt gaan omdat de kinderen hier op de NICU allemaal anders reageren. Dus als een kind met een kloppend hart wordt geboren, ga je aan de slag. Hoe slecht het er ook aan toe is.

We hebben hier wel eens een kind zonder nieren gehad. Deze diagnose was al voor de geboorte bekend. De ouders wilden daarom het kind na de geboorte bij zich houden zodat het in hun armen zou kunnen sterven. Maar toen het werd geboren bleck het hart te kloppen. Dus moesten we aan de slag gaan. Dat waren we aan het kind verplicht. Het was verschrikkelijk. De moeder bleef maar roepen dat ze haar baby terug wilde hebben. Maar wij namen het mee naar de NICU om het te behandelen. Daar overleed het een paar uur later. Maar ja, als het hart klopt, kun je je niet omdraaien. Zelfs als er geen hartactie is, heb je niet de zekerheid dat alle kansen verkeken zijn. Ik ga meestal twintig minuten door met reanimeren. Als de hartactie na twintig minuten niet op gang is gekomen heb je tenminste wel het gevoel dat je er alles aan gedaan hebt wat mogelijk is. Met medicijnen en zo. Meer kun je niet doen. Ook in het geval van een juridische claim sta je dan sterker.

In het Northeastern dwingt een kloppend hart tot actief ingrijpen. De interventie wordt gerechtvaardigd door verwijzing naar de kansen die een kind kan hebben en daarin speelt ook een rol of die kansen verder reiken dan het heden. Een arts-assistent in het Northeastern zegt in dit verband:

'Elke ingreep leidt tot meer kennis en vaardigheid. Met het behandelen van een kind van 23 weken neemt tegelijkertijd de kans toe dat ik een kind van 24 weken kan redden. De ervaring die ik bij de 23-weker opdoe, komt zo ten goede aan andere kinderen.'

Bovenstaande uitspraken tonen het dwingende karakter dat van kansen uitgaat. 
In de verloskamer van het Academisch Centrum is ingrijpen op basis van louter de aanwezigheid van een kans echter geen gewoonte. Het feit dat een kind na de bevalling een overlevingskans heeft, dwingt hier geen behandeling af, maar laat ruimte voor andere handelingsmogelijkheden, zoals het intrauterien laten sterven van het kind. Bij een dergelijke keuze hebben ouders het laatste woord. In het geval waarmee ik dit hoofdstuk begon vraagt de vader de artsen het kind te 'halen', zodat het behandeld kan worden. Ook de moeder kiest voor dit traject, maar wel op basis van geheel andere overwegingen:

'Op een gegeven moment werd de hartslag steeds trager en viel zo nu en dan zelfs helemaal weg. Je kunt je niet voorstellen hoe het is om te horen hoe de hartslag van je kind opeens stopt en daarna weer na een paar tellen verder gaat. Bij elke onderbreking dacht ik steeds dat het de laatste was en dat het hart niet meer op gang zou komen. Die momenten kwamen steeds frequenter. Er werd toen gesproken of we het kind moesten laten komen of niet. Er moest snel iets gedaan worden want ik voelde dat het kind het hooguit nog maar een uur zou volhouden. Er moest dus snel iets worden gedaan. Ik wilde pertinent niet dat het kind in mijn buik zou overlijden. Dat ik met cen dood kind in mijn buik zou zitten, dat vond ik zo'n verschrikkelijk idec. Het moest er gewoon uit.'

De moeder heeft dus een heel ander beeld van de situatie dan de vader of de neonatoloog. Zij hoort geen getallen, geen overlevingspercentages: zij hoort alleen een alarm dat aangeeft dat haar kind elk moment in haar buik kan overlijden. Voor haar zijn de getallen op de monitor niet zozeer een indicatie van de neonatale conditie van het kind, maar van de foetale conditie. Het gaat haar in de eerste plaats om de getallen op de monitor, het alarm dat steeds vaker afgaat en de gedachte dat het kind zich in háár buik bevindt. Zij definieert de situatie van het kind dan ook in geheel andere termen: een kind dat elk moment in haar buik kan overlijden!'Bevangen door angst, reikt haar blik niet verder dan de geboorte zelf. Alles wat volgt, blijft buiten haar gezichtsveld. Voor haar telt alleen het heden en dat vertelt haar maar één ding: het kind moet eruit!

Het zal duidelijk zijn dat het probleem in de verloskamer door geen van de betrokkenen volledig kan worden overzien. $\mathrm{Zij}$ definiëren de situatie dan ook elk op hun eigen manier. Om zicht te krijgen op de verschillende opties, delen de betrokkenen hun kennis, ervaring, opvattingen en gevoelens met elkaar. De artsen zien zowel foetale als neonatale nood, wat hen doet aarzelen over de wijze waarop de zwangerschapsvergiftiging het beste kan worden behandeld. De ouders krijgen derhalve het laatste woord. De vader ziet een kind met een kans dat dient te worden behandeld, terwijl de moeder een kind ziet dat elk moment kan overlijden en eruit gehaald moet worden.

De uiteenlopende definities van de situatie leiden uiteindelijk toch tot één keuze: via een keizersnede komt het kind ter wereld. Zij krijgt de naam 'Esther' 
en wordt direct aan de beademing gelegd en overgebracht naar de intensive care unit van de afdeling Neonatologic. Hoewel haar ouders op een verschillende manier tegen de situatie aankijken, komen zij bij hetzelfde handelingstraject uit. De moeder maakt cen actieve keuze voor het eerste deel van het traject, de operatieve bevalling, en de vader voor het tweede deel van het traject: de opname van het kind op de NICU.

\section{De constructie van kind en afdeling}

Het probleem van het definiëren van de situatie doet zich niet alleen voor in de verloskamer. Het keert voortdurend terug in de behandeling van pasgeborenen. Hoe gaat men op de NICU met dit probleem om? Welke instrumenten worden daarbij gebruikt? Waar komen de gegevens vandaan op basis waarvan men aan de slag gaat om de toestand van een pasgeborene vast te stellen?

\section{Het kind als constructie}

Een kind op de NICU draagt een voornaam en een achternaam; het wordt in de status geschreven, op de daglijst genoteerd en in de computer ingebracht. ${ }^{2} \mathrm{Het}$ kind heeft jonge ouders, alleenstaande ouders, bezorgde ouders, ouders die wel of niet op bezoek komen, ouders die in het ziekenhuis slapen of gewoon thuis verblijven. Het heeft broertjes en zusjes of het is de enige kans die ouders hebben om hun kinderwens te vervullen. Het 'kind met een kans' wordt 'Esther, onze dochter.'. 'Het kind dat eruit moet' verandert in een kind met een eigen gezicht, waarin ouders al dan niet een sprekende gelijkenis ontdekken. Kortom, zodra het kind geboren is, gaat het deel uitmaken van een groter geheel; van een familieverband, de familiegeschiedenis, de maatschappij.

Maar zolang een kind op de NICU verblijft, is het vooral patiënt en domineert de lichamelijke conditie zijn identiteit. Bij opname op de NICU is er nauwelijks iets bekend over het kind; hij of zij is grotendeels een onbeschreven blad. Deze onbepaaldheid is kenmerkend voor het werk van deze afdeling; een groot deel van de handelingen die er plaatsvinden zijn gericht op het achterhalen van de identiteit van het kind. Hoe beschrijven stafleden het kind als patiënt? Welke handelingen moeten zij verrichten en welke middelen zetten zij hierbij in? Voor de beschrijving van dit proces volg ik het verdere verloop van de opnames van Esther en Tom. Ook Tom is onmiddellijk na zijn geboorte opgenomen op de NICU van het Academisch Centrum. 


\section{Academisch Centrum}

$\mathrm{Na}$ binnenkomst wordt Tom direct in zijn bed gelegd: een couveuse met bijbehorende monitor, omgeven door een keur aan medisch-technologische apparatuur. Een verpleegkundige koppelt de zuurstofslang aan een beademingsapparaat dat naast de couveuse staat. De arts-assistent: 'We beginnen bij 20 over 4 met een frequentie van 55 op $100 \%$. Afhankelijk van hoe hij het doet kunnen we zakken.' Het beademingsapparaat wordt ingesteld.

Tom is nog maar nauwelijks binnen of cen stroom van vragen breekt los: hoe verliep de bevalling, hoe hoog is zijn glucose, hoe zien zijn bloedgassen eruit, hoe klinken zijn longen en wat is het geboortegewicht? Om een antwoord op deze vragen te krijgen wordt Tom uitgebreid onderzocht. Voorzichtig beluistert de arts zijn longen en hart.' Zacht duwt hij zijn hand in de flank van het kind en onderzoekt de lever. Een verpleegkundige brengt elektrodeplakkers aan op de kleine borstkas. Al snel verschijnen verschillende getallen op de monitor. Hartslag, ademhaling en temperatuur worden nu continu geregistreerd. De output van het bloeddrukbandje om zijn arm en de saturatiemeter" om zijn voetje verschijnt bij de andere getallen op de monitor. Om de lichaamstemperatuur van Tom op peil te houden wordt de warmte in de couveuse geregulectd. Ouk heijgt hij eeit mutsje op. De aits neemit met een verpleegkundige de medicatic en bloedonderzoeken door. 'Laten we een astrup doen, een glucose, VBO en een bili.' Milligrammen en eenheden worden opgesomd. Ondertussen heeft iemand de Röntgenafdeling gebeld. Een foto zal uitwijzen of de tube van de zuurstofslang op de juiste plaats is ingebracht.'

De attending* komt binnen en schaart zich bij het groepje rond de couveuse. 'Is dit die overplaatsing waar vanmiddag over gebeld werd?' 'Ja, zijn broertje is overleden. 'Hoe doet hij het?' 'Voor zijn leeftijd goed. Hij had een APGAR" van 3,7 en 9 .' 'Hij past mooi in de surfactantstudie. Heeft hij al surfactant" gehad?' 'Nee, dat moet ik nog doen. Eerst even een infuus zetten.' Het inbrengen van het infuus wil niet lukken. Kleine kinderen zoals Tom hebben zulke tere vaatjes dat daar al snel doorheen geprikt wordt. Na nog twee pogingen zit het infuus op de juiste plaats. Door dit infuus krijgt hij zijn medicatie. Een ander infuus dient voor de voeding. Met behulp van een perfusor* wordt de inloopsnelheid van elk infuus geregeld. Hierdoor is het mogelijk om met grote precisie zijn voeding over vierentwintig uur te verdelen. Om te voorkomen dat een infuus eruit schiet, wordt de arm waar het infuus in zit met behulp van een spatel gespalkt.

Al snel ligt zijn couveuse vol met slangen en draden, driewegkranen en aansluitpunten van de monitor. De verpleegkundige plakt een 'jongensblauw' kaartje aan zijn couveuse waarop met grote letters 'TOM' staat geschreven. 
De transformatie van 'onbepaald' naar 'bepaald' verloopt allerminst vanzelf. De opname van Tom laat zien hoeveel werk de staf moet verzetten om te ontdekken wat voor een kind men 'in handen' heeft. De opname markeert het begin van een stroom aan activiteiten en handelingssequenties gericht op de vraag: 'wie is dit kind dat hier zojuist is binnengekomen?' Alle bedrijvigheid heeft als doel het kind zo snel mogelijk een eigen gezicht te geven. Zijn identiteit wordt opgebouwd uit een veelheid aan direct verzamelde gegevens over familiebanden, onderzoeksuitslagen, uiterlijke kenmerken, enzovoort. Deze elementen zijn echter niet allemaal even stabiel. Sommige testwaarden of vitale gegevens kunnen plotseling veranderen en tevens de identiteit van het kind drastisch wijzigen. Dit was bijvoorbeeld het geval bij Esther.

\section{Academisch Centrum}

Maandag: Esther is één dag oud. Er is een echo van haar hoofd gemaakt. Deze toont een vierdegraads hersenbloeding aan de linkerkant van haar hoofd.

10.30 uur: De ouders van Esther komen op bezoek. Vanmorgen vroeg is Esthers vader al op de afdeling geweest. Nu komt haar moeder ook mee. $\mathrm{Zij}$ is nog te zwak om te lopen en wordt met bed en al naar de couveuse gemanocuvreerd. De moeder durft Esther niet aan te raken. Ze staart onwezenlijk in de couveuse. $\mathrm{Na}$ tien minuten wil ze weer terug naar de kraamafdeling.

12.00 uur: Een tweede echo van het hoofd toont een uitbreiding van de bloeding naar de rechterhelft van het hoofd.

16.0o uur: Het gaat niet goed met Esther. Haar longen verkeren in een dusdanige onderontwikkelde toestand dat zelfs maximale ondersteuning van het beademingsapparaat nog niet voldoende is om de saturatiewaarde omhoog te krijgen. Ook het glucose en ijzergehalte is te laag. Daarnaast heeft Esther voortdurend een te lage bloeddruk en een ondertemperatuur. Voor deze problemen zijn vele middelen ingezet. Echter, niet alle interventies slaan aan. De arts-assistent heeft haar handen er aan vol, maar slaagt er niet in de toestand van Esther te stabiliseren.

De gemaakte echo's laten zien dat de situatie van Esther geheel is gewijzigd. 'Wie of wat het kind vandaag is, zegt niets over morgen', is niet voor niets een veelgehoorde waarschuwing van neonatologen aan arts-assistenten. Toch zou het verkeerd zijn om te suggereren dat de definiëring van de situatie van een kind op de NICU een heilloze zaak is, waarbij chaos en contingentie de boventoon voeren. Ook op de NICU is identiteit geen willekeurige opeenstapeling van heterogene elementen, maar bezit identiteit een structuur. 


\section{Identiteit als geordend complex}

De identiteit van een kind op de NICU bestaat altijd uit een complex van betekenissen, maar het is wel een geordend complex. Deze orde komt echter niet vanzelf tot stand. Het is aan de staf om structuur aan te brengen in de verzameling van gegevens. In dit ordeningsproces vormt het dagelijks onderzoek van de arts een belangrijke factor.

\section{Academisch Centrum}

8.45 uur: de arts-assistent wandelt de afdeling op. Zij is net terug van de medische overdracht. Op dit moment zijn zeven van de negen plaatsen bezet. De arts gaat aan de tafel in het midden van de NICU zitten, pakt een pen en rekenmachine en begint met het dagelijks onderzoek van de kinderen. Zij pakt de status van Tom die boven op de stapel ligt. In de decursus, het gedeelte waar de arts het verloop van de behandeling beschrijft, stempelt zij het schema waarin ze de temperatuur, het gewicht, de opname van vocht en voeding en output van urine en ontlasting kan noteren. Deze gegevens kan zij zo overnemen van de daglijst zoals deze is opgesteld door de verpleegkundigen die Tom de afgelopen vierentwintig uur hebben gecontroleerd. Omdat veel items bij hem om de drie uur zijn gemeten, rekent de arts-assistent het gemiddelde uit of noteert zij het bereik.

$\mathrm{Na}$ de daglijst bekijkt ze alle uitslagen die gisteren van het biochemisch en hematologisch lab zijn binnengekomen. Aan de hand van de bloedwaarden berekent zij de stand van het zuurstofapparaat. Ook de verslagen van de intercollegiale consulten over röntgenfoto's en echo's neemt ze door. Ze bladert door de status, loopt nog eens door de voorgaande dag heen en leest de rapportage van haar collega in de nachtdienst. Tom lijkt zich te stabiliseren.

Met dit beeld in haar hoofd staat de arts-assistent op om Tom te onderzoeken. Er is inmiddels meer dan een kwartier verstreken. Zij wast haar handen en opent de deurtjes van de couveuse. Ze past het licht enigszins aan zodat ze zijn huidskleur goed kan zien. Vervolgens pakt zij de stethoscoop die bij zijn couveuse hangt en beluistert het hart en de longen en de bewegingen in Toms buik. Op de HC staat zachtjes de radio aan. Blijkbaar toch te hard voor een nauwkeurige beluistering van een kind op de IC. Op haar verzoek wordt de radio uitgedraaid en beluistert ze opnieuw zijn hart en longen. Vervolgens beoordeelt ze de milt en lever. In de liezen en aan de hiel voelt ze de pulsaties van de bloedsomloop. Met een zachte druk in de zij gaat ze na of Tom vocht vasthoudt. Ze zockt naar de aanwezigheid van plotselinge eigenaardigheden, maar ontdekt niets bijzonders. Voorzichtig legt ze hem weer in de meest comfortabele positie, doet de deurtjes dicht en wandelt terug naar de tafel waar ze de resultaten onder de gegevens van de daglijst noteert. 
Opnieuw pakt zij haar rekenmachine en berekent de samenstelling van de parenterale voeding*. Op basis van zijn gewicht krijgt Tom een bepaalde hoeveelheid glucose. Zo worden ook de hoeveelheden vitaminen, mineralen en vetten uitgerekend. Dit alles schrijft ze bij in de status. Straks als ze alle kinderen heeft nagekeken, zal ze deze berekeningen per computer naar de apotheek sturen. Daar wordt op basis van deze gegevens de infuusvoeding klaargemaakt.

De arts heeft nu alle benodigde feiten over Tom op een rijtie en kan de evaluatie schrijven. Ze beschrijft puntsgewijs de problematiek van Tom, de behandeling en de bijbehorende onderzoeken. Straks bij de visite zal zij dit beleid met de dienstdoende neonatoloog doornemen. Ze slaat de status dicht en pakt de volgende van de stapel.

De arts bepaalt hier de situatic van Tom vooral zittend aan tafel, met pen en rekenmachine in de hand. Op het eerste gezicht lijkt dit de plek noch het instrumentarium om een kind te onderzoeken. Maar een arts die de toestand van een kind moet bepalen, kijkt niet alleen in de couveuse. Ook de status wordt erbij gepakt, de daglijst wordt bekeken en de getallen op de monitor. Het kind en de representaties ervan lijken hier samen te vallen. Het kind is aanwezig in de status, op de daglijst, op de monitor en in de couveuse. Het 'bestaat' niet alleen op een monitor of in gesprekken tussen stafleden, maar ook op laboratoriumaanvragen in de buizenpost, op de lichtbakken van de Röntgenafdeling en in het centrale computerbestand van het ziekenhuis. Het netwerk waarin de situatie van een kind wordt gedefinieerd, reikt tot ver buiten de afdeling. Het kind ligt vast aan apparatuur en zijn vitale gegevens verschijnen op papier, op plastic en op beeldschermen. Meer en meer wordt het zo ingesponnen in het web dat de alledaagse praktijk van de NICU vormt.

Rond het kind komen verschillende elementen van uiteenlopende aard samen: getallen, woorden, papier, machines, instrumenten, lichamen, beslissingen en de architectuur van de afdeling. Om op basis hiervan de toestand van het kind te kunnen vaststellen, analyseert de arts de stapels papier op tafel. ${ }^{6} \mathrm{De}$ tafel in het midden van de NICU fungeert als het 'ordering centre.' Hier worden de verschillende elementen bij elkaar gebracht. Door middel van het vergelijken en combineren van gegevens tracht de arts het materiaal tot een eenduidig geheel om te vormen. Daarbij fungeert de status als een centraal knooppunt. De gegevens van de daglijst, de onderzoeksuitslagen en de resultaten van het lichamelijk onderzoek worden door de arts in de status bijgeschreven. Schrijven is hier niet zozeer informatieoverdracht, maar ordening.' In de status komt alles samen en er ontstaat een overzicht van het verloop van de toestand waarin het kind verkeert. De status laat zich lezen als het logboek van de reis. De route die het kind gedurende de opname aflegt wordt hierin uitgetekend. Naast de notities die artsen in de status maken, werkt de afdelingssecretaresse dagelijks de 
status bij. $\mathrm{Zij}$ verwerkt onder meer de daglijst die de verpleegkundige de dag ervoor heeft ingevuld in de status. Ze vult het soort en de hoeveelheid voeding en medicatie in. Krijgt het kind fototherapie (de blauwe lamp), packed cells (bloedtransfusie), een infuus, de zuurstofdruk en de vorm van kunstmatige beademing? Heeft het kind gebraakt, gepoept, geplast? De gekleurde curven van de temperatuur (rood), ademhaling (zwart), polsslag (blauw) en gewicht (groen) trouw bijgewerkt door de afdelingssecretaresse - lopen door elkaar. Voeding, medicatic, instellingen van infuus en beademingsapparaat staan in hokjes naast elkaar. Eén blik op dit geheel vertelt de arts direct hoe een kind er aan toe is en welke ontwikkeling het achter de rug heeft. De status fungeert zo als een 'centre of representation". Het lezen van een status vereist wel kennis van zaken. Veel van de informatie is vervat in afkortingen en getallen. Combinaties van letters verwijzen naar behandelingen, instrumenten, medicijnen, opdrachten, overlegvormen, zicktes, symptomen en disciplines. Wie of wat het kind is, wordt verteld in een kwantitatieve taal. Sommige getallen fungeren als basis voor berekeningen en leven onzichtbaar voort in gemiddelden, bereik, ratio of apparatuurinstellingen. Andere gegevens worden onveranderd overgenomen en gaan in de status nieuwe relaties aan. Uitslagen van bloedwaarden worden gekoppeld aan de instelling van het beademingsapparaat, de kubieke centimeters en percentages in het voedingsinfuus worden gerelateerd aan de grammen van het gewicht.

De aldus opgebouwde identiteit van het kind bestaat niet uit een willekeurige hoeveelheid gegevens, maar is een doordachte compositie. Verzamelde feiten staan niet op zichzelf, maar krijgen pas betekenis in samenhang met andere gegevens. Een uitslag wordt beoordeeld in het licht van de normaalwaarde uit het medisch handboek, de voorgaande uitslagen in de status en overige onderzoeksresultaten. Zo kan de gele huidskleur van een kind de uitslag van de bilirubine* onderstrepen, terwijl een hoge temperatuur bij een positieve uitslag van een bacteriekweek kan wijzen op een ontsteking. Pas in relatie tot andere gegevens krijgt een bepaald resultaat zijn inhoud en wordt deze normaal of afwijkend, te hoog of te laag, zorgelijk of hoopvol. De identiteit van een kind komt zo tot stand in een bepaalde orde van passen en meten, rekenen, vergelijken, overleggen, observeren, voelen, luisteren, lezen en combineren. De wijze waarop een arts het materiaal ordent, lijkt op die van een puzzeloplosser."

De wisselende toestand van een kind maakt van de aangebrachte orde echter slechts een momentopname. Het bestaan van 'pools of order' is dan ook een illusie." Artsen realiseren zich dat hun instrumentarium beperkt is en dat de gegevens waarmee zij werken een hoge omloopsnelheid hebben. In het besef dat nieuwe gegevens elk moment het bestaande beeld kunnen ondermijnen, streven artsen niet naar een bepaling van het 'ware' beeld of de 'uiteindelijke' identiteit van het kind. Dat is onmogelijk. Ze stellen zich derhalve tevreden met een 
beeld dat hen voldoende zicht geeft om de volgende stap op het behandelingstraject te kunnen zetten. Geen 'ware' maar een werkbare identiteit is het pragmatische doel van het medische ordeningsproces op de NICU.

\section{De afdeling als constructie}

Het kind krijgt een identiteit als gevolg van dagelijks terugkerende handelingen. Dit werk voorziet tegelijkertijd de afdeling zelf van een structuur. Het kind en de omgeving nemen in onderlinge wisselwerking vorm aan. Zo is het tekenend voor een NICU dat men voor een antwoord op de vraag 'wie is dit kind?' apparaten aankoppelt en naar knipperende getallen op de monitor kijkt. Een dergelijk handelingspatroon zal men thuis in de kinderkamer niet snel aantreffen. Op de NICU is het echter 'normaal' dat de naam van het kind met getallen van twee cijfers achter de komma verweven raakt of dat men het hart beluistert, de lever beoordeelt en de longen fotografeert of dat er steeds buisjes bloed richting laboratorium gaan. Het gaat er immers om het kind te leren kennen. Door deze lokale procedures, routines en vocabulaires wordt de identiteit van het kind opgebouwd.

De activiteiten met betrekking tot het kind geven ook een specifieke invul-

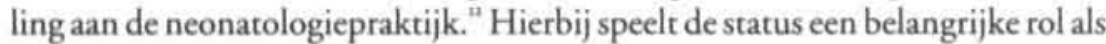
structurerend apparaat voor het verzamelen van gegevens over het kind." Behalve een 'centre of representation' is de status ook een 'ordering center'. De structuur en indeling van de status organiseren de activiteiten van de arts; hij zal bepaalde aspecten van het kind moeten onderzoeken om de (nog) lege vakjes te vullen. Op deze wijze bepaalt de status de dagelijkse routines en handelingen van de staf." De status is ook een hulpmiddel in de structurering van professioneel gedrag." Het gezamenlijke gebruik ervan is alleen mogelijk op basis van een code of practice, die elke arts moet aanleren en handhaven."

We hebben gezien dat bij een kind op de NICU de lichamelijke conditie centraal staat. Deze conditie is complex en instabiel. Dit heeft implicaties voor de structurering van de afdeling. De kwersbaarheid van de kinderen maakt een voortdurende aanwezigheid van artsen en verpleegkundigen noodzakelijk. Deze vierentwintiguurs bewaking wordt door middel van ploegendienst (dagdienst, avonddienst, nachtdienst en weekenddienst) gegarandeerd. Om informatieoverdracht mogelijk te maken, begint de volgende dienst iets eerder dan de daaraan voorafgaande dienst eindigt. Dit betekent dat de overdrachtsmomenten vastliggen. De kwetsbaarheid van de kinderen die op de NICU liggen, brengt nog een andere temporele structuur in. Zo controleren verpleegkundigen op vaste tijden verschillende parameters bij het kind. Afhankelijk van de conditie van het kind wordt dit om de twee uur of om de drie uur gedaan. Deze controle- 
rondes spelen een dominante rol in de organisatie van het verpleegkundig werk en zij bepalen de planning van hun activiteiten.

Ook andere aan de behandeling gerelateerde zaken dragen bij aan de definiëring van de afdeling. Zo verdraagt de instabiele conditie van deze kinderen bijvoorbeeld geen communicatiestoornis tussen stafleden. Om misverstanden te voorkomen zijn er naast de informele gesprekken op de NICU ook formele momenten van communicatie over de toestand van de kinderen, zoals de dagelijkse visite en de overdracht. Deze momenten fungeren als vaste punten in de dagelijkse dynamiek van de NICU-praktijk. De overdracht tussen de verschillende diensten (nacht-, dag-en avonddienst) is echter meer dan alleen een moment van onderlinge communicatic tussen verpleegkundigen of tussen artsen. De instabiele conditie van de kinderen op de NICU stelt namelijk bepaalde eisen aan deze besprekingen: een overzichtelijke presentatie van relevante informatie. Dergelijke momenten van overdracht fungeren hierdoor ook als tijdslimiet: vóór de overdracht moet bepaalde informatie beschikbaar zijn en moeten bepaalde handelingen reeds zijn uitgevoerd. Daarnaast is het tekenend voor de NICU dat een dergelijke bespreking in voornamelijk kwantitatieve termen en afkortingen gevoerd wordt. De dagelijkse visite is eveneens meer dan een moment van gezamenlijk overleg. Ook deze bespreking geldt als tijdslimiet: de arts-assistent moet voor de visite alle kinderen op de NICU hebben nagekeken, de gegevens op orde hebben en een plan van aanpak kunnen presenteren. Het tijdstip waarop de visite plaatsvindt wordt bovendien bepaald door de organisatie van de apotheek elders in het ziekenhuis. Een kind op de NICU krijgt namelijk meestal de voeding per infuus. Een voedingsinfuus loopt vierentwintig uur. Het begin van deze cyclus ligt op vijf uur 's middags. Wil de apotheek de infusen om vijf uur beschikbaar hebben, dan moet zij voor twaalf uur de nodige informatie in bezit hebben. Dit betekent dat de visite waarin eventuele wijzigingen in de voeding worden besproken, voor twaalf uur moet zijn afgerond, wil de arts-assistent de definitieve afspraken over de voeding nog aan de apotheek kunnen doorgeven. Op een indirecte wijze legt het verwisselen van het voedingsinfuus aan het eind van de middag een tijdsdruk op de activiteiten die er 's morgens op de afdeling plaatsvinden. Deze tijdsdruk leidt er ook toe dat er bijvoorbeeld in de morgen geen enkele ruimte meer overblijft voor gesprekken met ouders. Die vinden dan ook meestal in de middag plaats. Dan is er niet alleen meer ruimte voor een gesprek met de ouders, maar is ook de uitkomst van de dagelijkse visite bekend. Spreken met ouders vraagt immers niet alleen aandacht, maar ook eenduidige informatie.

De NICU bestaat niet los van de artsen, de verpleegkundigen en de ouders, of van de handelingen die er worden uitgevoerd en de taal die er wordt gesproken. De orde van de afdeling zit in de uitvoering van controlerondes, de onderlinge communicatie, de verwerking van kwantitatieve informatie en de gesprekken met 
ouders. Het zijn deze factoren die eveneens inhoud geven aan wat een NICU is. In deze praktijk ontstaan aldus historische patronen, routines en rollen waarin zowel het kind als de afdeling wordt geconstrueerd. De identiteit van het kind én de structuur van de afdeling komen zo in én en hetzelfde proces tot stand.

\section{Wijzen van redeneren}

\section{Academisch Centrum}

Maandag 18.00 uur: Met Esther gaat het steeds slechter. De bloedcirculatie blijft zeer matig. De monitor vertoont wisselende saturatiewaarden en een schommelende bloeddruk. Zuurstof en medicatie worden opnieuw aangepast. Haar ouders zijn ingelicht over de resultaten van de tweede echo.

19.30 uur: Opnieuw zijn er problemen bij Esther. Het zuurstofapparaat wordt op $60 \%$ gezet. Langzaam trekt de saturatie bij tot $90 \%$. In de longen wordt ademgeruis gehoord.

21.45 uur: De longen van Esther klinken slechter. De röntgenafdeling wordt gebeld voor een foto. Deze toont vocht in de longen en een vergroting van het hart.

Dinsdag 10.00 uur: Esther ligt bleek en slap in haar couveuse. Gedurende de nacht zijn er steeds frequenter wisselende waarden op de monitor verschenen en uit het laboratorium teruggekomen. De artsen bekijken voor de zoveelste keer de uitslagen. De attending trekt zijn conclusie: 'Het wordt niets meer, laten we maar stoppen. Ik stel voor dat we vanmiddag om half twee in de stafkamer hierover bij elkaar komen.'

Net als in de verloskamer moet opnieuw een keuze worden gemaakt uit twee behandelingstrajecten: stoppen of doorgaan. Esther is drie dagen oud. Haar behandeling slaat niet aan en steeds vaker klinken er sombere geluiden bij haar couveuse: 'Wat we ook doen, het slaat maar niet aan. Zolukt het ons nooit', 'Als er niet iets verandert zie ik het somber in'; 'Ze knijpt er tussenuit'. Dergelijke uitspraken worden gevoed door een stroom ongunstige labuitslagen, door grillige frequenties op de monitor, medicatie die niet of nauwelijks aanslaat en echo's en röntgenfoto's die geen verbetering laten zien. Nu gaat het om de vraag of de behandeling al dan niet moet worden gecontinueerd. De attending constateert bijvoorbeeld dat de voortzetting van de behandeling geen zin meer heeft. Het staken van een behandeling is een beslissing die hier altijd in onderling overleg genomen wordt. Daarom wordt er een stafvergadering belegd.

Om zicht te krijgen op de situatie van het kind dienen ook in de stafvergadering alle gegevens weer geordend te worden. Hierbij gebruikt men verschillende methodes. Dit ordeningsproces in de discussie kan worden beschreven aan de 
hand van het begrip 'repertoire'. Met een 'repertoire' doel ik op een 'stijl' van redeneren. Het is het sturende principe dat onze idecén ordent over wat de wereld is en hoe die in elkaar zit. Deze sturing dient echter niet strikt te worden opgevat. Het legt dus niet precies vast wat er gezegd of gedaan zal worden, maar bepaalt wat betrokkenen als relevant beschouwen, welke argumenten of middelen er volgens hen toe doen." Het geeft aan wat centraal staat of zich meer in de periferie ophoudt. Het is een manier om beslissingen te legitimeren. Met behulp van dit begrip wil ik laten zien hoe de deelnemers in de stafvergadering de gegevens selecteren en rangschikken om de situatie van Esther te bepalen. Door welk repertoire laten zij zich leiden?

\section{Academisch Centrum}

13.30 uur: De stafvergadering begint. Onderwerp van gesprek is het voorstel om de behandeling van Esther te staken. Aanwerig zijn de attending onder wiens verantwoordelijkheid Esthers behandeling valt, de arts-assistent die dienst heeft op de NICU, twee verplecgkundigen die Esther verzorgd hebben, twee andere neonatologen en een maatschappelijk werkster.

De arts-assistent opent de vergadering met een verslag van het verloop sinds de geboorte en de huidige conditie van Esther. Zij eindigt haar inleiding met de vraag: 'Wat is het verdere beleid gezien de huidige problemen en rekening houdend met het leven van het kind in de nabije toekomst gezien het feit dat de prognose zeer slecht is?'

'Wat is zeer slecht?', vraagt de maatschappelijk werkster aan de arts-assistent.

'Een bloeding graad vier aan beide kanten van het hoofd maakt haar kans op overleven zeer klein en als ze overleeft, over wat voor leven hebben we het dan?', luidt haar antwoord.

'Wat vinden de ouders?', vraagt een verpleegkundige.

De arts-assistent: 'Als hun kind erg gehandicapt is, willen ze niet dat we blijven doorgaan.'

Ook de maatschappelijk werkster heeft met de ouders gesproken: 'De ouders hebben er geen spijt van dat ze hebben besloten Esther te laten behandelen. Ze hebben wel hun bedenkingen als het kind heel ernstig gehandicapt zou zijn. Daarvan hebben ze gezegd: 'Dat willen we het kind niet aandoen en onszelf ook niet.' Ze hebben eigenlijk op grond van de informatie die ze tot nu toe gekregen hebben, voor zichzelf al de conclusie getrokken dat ze er rekening mee moeten houden dat het kind gaat overlijden. Daarom willen ze het kind in ieder geval nog laten dopen. Dat zou vandaag nog kunnen gebeuren.'

In de eerste tien minuten van de vergadering zijn alleen de stafleden aan het woord geweest die de afgelopen dagen voortdurend rond de couveuse van Esther te vinden waren. Als we naar de manier kijken waarop zij hun verhaal doen, dan blijkt dat zij allemaal een repertoire hanteren waarin de specifieke 
situatie van het kind centraal staat. Deze sprekers gebruiken een situationeel repertoire. In dit repertoire wordt de eigenheid van een situatie op de voorgrond geplaatst. Het positioneert de persoon - in dit geval het kind - in deze tijd en deze ruimte. Het kind wordt expliciet in verband gebracht met bepaalde personen, plaatsen en momenten en op deze wijze geïndividualiseerd. Esther is een kind van hier waar nueen beslissing over moet worden genomen. Dit repertoire domineert de eerste minuten van de vergadering.

Tot hier toe beperkt de discussie zich alleen tot Esthers situatic. Vraag en antwoord wisselen elkaar af en alles en iedereen lijkt zich in de richting van een abstinerend beleid te bewegen. Vervolgens neemt de discussie een wending waardoor al het voorgaande onder druk komt te staan. Twee neonatologen die niet direct bij de behandeling van Esther betrokken zijn, mengen zich in het gesprek. Eén van hen vraagt naar cen EEG-uitslag*.

De arts-assistent: 'Er is geen EEG gemaakt. Als je denkt dat het zinvol is voor het bepalen van het beleid zal er één gemaakt moeten worden. Maar wat zijn de criteria die je dan gebruikt wanneer de resultaten van de EEG binnenkomen?'

De neonatoloog: 'Ik denk dar als je een normale EEG hebt, je niet zo' $n$ beslissing kunt nemen.'

'Denk je,' vraagt de arts-assistent, 'dat er met deze cerebrale conditie een kans bestaat op een normale EEG? Begrijp me goed, ik probeer de grenzen af te tasten van wat dan je parameters zijn om beleid op af te stemmen.'

De andere neonatoloog steunt het voorstel van zijn collega: 'Ik denk dat een EEG een waardevol onderzoek is. Waar we hier voor staan, is om samen te proberen de prognose van dit kind te bepalen. Dat is moeilijk als je alleen naar de echo kijkt. Ik vraag me af of we op basis van een echo een dergelijke beslissing mogen nemen. Uit de literatuur blijkt dat een graad vier bloeding op zich niet alles zegt. Ook de locatic en de uitbreiding spelen een rol. Er wordt een onderzoek beschreven van twintig kinderen met een graad vier bloeding waarvan er éen slechts matig gehandicapt is. Ik vraag me daarom af of we op basis van de huidige gegevens wel tot een abstinerend beleid mogen overgaan.

Anders dan de direct betrokkenen zijn deze twee neonatologen nog niet geheel overtuigd van de uitzichtloosheid van Esthers situatic. Zij brengen echter niet alleen een andere mening in, maar ook een ander repertoire, namelijk een gevalsrepertoire. In een gevalsrepertoire wordt het kind beschouwd in relatie tot vergelijkbare gevallen. Hiermee reikt dit repertoire voorbij de grenzen van de situatie van het kind dat ter discussie staat en wordt de buitenwereld binnengehaald. De vergadering gaat niet meer alleen over Esther, maar ook over criteria om cen EEG-uitslag te beoordelen, over parameters om een beleid op af te stemmen en over anonieme kinderen die als statistische eenheden in de literatuur beschreven staan. Het gevalsrepertoire maakt het mogelijk andere aspecten van 
de identiteit van een kind te belichten. Zo wordt de dichotomie tussen algemeen geval en specifiek kind doorbroken. Ook Esther is 'een geval'.

Ook hier zien we weer een dubbele beweging: in de vergadering wordt niet alleen het kind gedefinieerd, maar ook de identiteit van de afdeling. Het gaat over hun verantwoordelijkheden en tot waar hun kennis en kunde zou moeten reiken. Ook waar het de definiëring van de afdeling betreft, plaatsen beide repertoires andere accenten en appelleren ze aan andere zaken. In een gevalsrepertoire reiken de elementen waaruit de identiteit van een afdeling is opgebouwd verder dan de concrete situatie. Men richt zich veel meer op algemene procedures en standaarden. In de stafvergadering is dit bijvoorbeeld zichtbaar op het moment dat één van de neonatologen voorstelt een radioloog erbij te betrekken:

'Ik denk dat, onafhankelijk van deze casus, het zorgvuldig is bij dit soort besprekingen een op schrift gesteld verslag van de röntgenoloog te verwachten.'

In dit voorstel staat niet de behandeling van Esther centraal, maar de gang van zaken met betrekking tot dit soort beslissingen. Voor deze neonatoloog stuit de NICU in deze situatie op haar grenzen. Met een beroep op zorgvuldigheid stelt hij daarom voor om buiten de afdeling een bevestiging van de prognose te zoeken. Hiermee wordt de afdeling niet alleen gerelateerd aan een andere medische discipline, maar aan een geheel ander domein. Het gaat niet meer alleen over medische zekerheid, maar ook over juridische zekerheid. Niet alle aanwezigen zien hier iets in.

'Wat ik hier proef is dat jullie een geparafeerde verklaring nodig hebben', stelt één van de verpleegkundigen vast. De artsen kijken haar verbaasd aan.

'Voor mezelf heb ik daar dus weinig behoefte aan', verdedigt de attending zich. 'In dit geval is het meer een kwestie van juridisch zeker staan dan van medische zekerheid. Ik heb zelf die zekerheid niet nodig.'

Toch blijft de vraag of men op de afdeling zelf deskundig genoeg is om de echo te beoordelen. De neonatoloog vindt van niet.

'Het is zorgvuldiger om er een deskundige naar te laten kijken', betoogt de neonatoloog opnieuw.

De attending is het niet met zijn collega eens: 'Ik vind dat wij ondertussen ook wel deskundig zijn als het gaat om het interpreteren van echo's. Wij, die dat al jaren doen, hebben meer ervaring dan de gemiddelde radioloog die dat bij ons komt doen. Stel dat we die bloeding op de echo niet hadden gezien en we hadden alleen het beeld gehad van het hypotensief zijn. Dan zouden we ons op dit ogenblik allemaal ernstige zorgen maken, wetende dat dit prognostisch een slecht teken is. We hebben diverse prognostisch slechte criteria met de relatief 
objectief gegeven bloedingen. Er is de voorgeschiedenis en dit kind is op dit moment stabiel slecht. Dan zou ik mee durven gaan om bij dit kind, dat van begin af aan een zeer slechte prognose had, te stoppen met behandelen. Althans dat te adviseren aan de ouders.'

De andere neonatoloog houdt echter aan: 'Mijn gevoel is dat er in deze groep geen $100 \%$ zekerheid is over de prognose om een heel strak geformuleerd advies te geven."

De attending toont nu enige irritatie: 'Maar ons vak is geen wiskunde. Ik denk dat je die zekerheid nooit krijgt. Er is altijd wel iemand die op basis waarvan dan ook, twijfel zou kunnen opwerpen. Dat kunnen we hier dus nu ook. Maar als je de hele toestand van het kind op een rijtje zet, dan mag je toch wel met zeer grote, ja bijna $100 \%$, zekerheid zeggen dat het prognostisch uitermate slecht is. Als het kind nog een kans op overleven heeft. Die kans acht ik op dit ogenblik minimaal.'

In het gevalsrepertoire dat de neonatoloog hanteert, wordt de NICU steeds opnieuw verbonden met de buitenwereld. Het is een afdeling die volgens hem rekening moet houden met externe invloeden zoals juridische regels en normen van zekerheid. De aanwezige deskundigheid op de NICU zou de vereiste zekerheid voor dit soort beslissingen onvoldoende kunnen garanderen. In dit repertoire is de NICU een afdeling die bij beslissingen met betrekking tot levensbeèindigend handelen verbonden moet worden met andere specialismen, zoals Radiologie. De neonatoloog koppelt dit beleidsvoorstel los van het kind dat in de vergadering ter discussie staat. Zijn voorstel is 'onafhankelijk van deze casus' en richt zich op 'dit soort besprekingen'. De attending daarentegen spreekt over de afdeling in andere termen. 'Ik vind dat wij ondertussen ook wel deskundigen zijn. Wij die dat al jaren doen...' '... dan praat ik nu gewoon als behandelend arts' en 'ons vak is geen wiskunde'. De attending richt zich op de prakrijk die zich binnen de afdelingsmuren voordoet."

\section{Het gebruik van repertoires}

De dienstdoende neonatoloog (de attending) en zijn collega hebben in deze situatie uiteenlopende opvattingen over de definitie van kind én afdeling. De artsen staan tegenover elkaar en legitimeren hun posities met behulp van verschillende repertoires. Met dit verschil lijkt het bijna onmogelijk om tot een gezamenlijk besluit te komen over de behandeling van Esther. De neonatologen spreken immers niet over hetzelfde kind en zij hebben evenmin dezelfde afdeling voor ogen. Uit het vervolg van de stafvergadering zal echter blijken dat de kloof tussen de repertoires overbrugbaar is. Dit vraagt wel een actieve inzet van de betrokkenen. De attending neonatoloog doet dit bijvoorbeeld door het voorstel van zijn collega neonatoloog enigszins om te buigen. 


\section{Academisch Centrum}

Wanneer de neonatoloog een uitgebreid schriftelijk verslag van een radioloog voorstelt, reageert de attending verbaasd: Maar dat duurt minstens twee weken en zoveel tijd hebben we niet. In dit geval lijkt mij dat een bevestiging van eén van de stafleden van de Röntgen ook volstaat."

Vanuit de noodzaak het onderhandelingsproces niet te laten verzanden, zoekt de attending naar een formulering die aan beide posities tegemoet komt. Op deze wijze gaat hij niet voorbij aan het verzoek van zijn collega én formuleert hij dat verzoek tegelijkertijd in termen van zijn eigen situationele repertoire. Zo'n reconceptualisering is een belangrijk middel om een besluitvormingsproces verder te brengen. Er moet immers gehandeld worden.

Het is niet alleen de attending die deze beweging maakt. Ook de neonatoloog zoekt naar een tussenoplossing waarmee hij zijn collega over de brug kan krijgen zonder zijn eigen voorwaarden opzij te zetten.

De neonatoloog: 'Ik zou zelf niet zo hard durven zeggen dat dit kind gaat overlijden.'

De attending: 'Ja oké, dat is een klinisch gevoel dat je dus kunt hebben. Maar als het kind het eventueel overleeft dan mag je daar toch bijna zeker van zeggen dat de kwaliteit uiterst somber zal zijn'.

De neonatoloog: 'Alleen als we ons dus niet vergissen in die interpretatie van de echo. Is het een idee om Rob (kinderneuroloog JM) nog eens te vragen. Of hij zo zijn ideeën heeft. Alleen kan hij het kind niet onderzoeken want het is gesedeerd. Hij kan wel naar de echo kijken en zijn advies geven over het al dan niet informatief zijn van een EEG.

De attending: 'Ik vraag me af of een EEG helpt bij het nemen van deze beslissing. Ik zou het zelf niet doen. Maar als iemand anders in deze groep daarmee het idee heeft dat we zorgvuldiger handelen, dan vind ik dat we aan dat bezwaar tegemoet moeten komen.'

Hoewel de neonatoloog niet afwijkt van zijn standpunt dat er extra zekerheid van buiten moet komen, is dit voorstel minder vergaand en meer 'op maat' gesneden voor deze situatie. Opvallend is dat de neonatoloog in deze herformulering overstapt van het gevalsrepertoire naar het situationele repertoire. Hij spreekt nu niet over dit soort situaties in het algemeen, maar over die van Esther en haar gesedeerde toestand in het bijzonder. Hij verwijst nu niet meer naar de afdeling Neurologie in het algemeen, maar naar één bepaalde kinderneuroloog. Een neuroloog die blijkbaar als een deel van de afdeling wordt ervaren, daar het enkel noemen van de voornaam hier volstaat. Repertoires blijken niet persoonsgebonden. 
Niet alleen kan de kloof tussen twee mensen die verschillende repertoires gebruiken worden overbrugd, ook kunnen beide repertoires worden ingezet om één en dezelfde conclusie te verdedigen, zoals één van de neonatologen op een gegeven moment doet:

'Maar ik proef bij Marije (de derde neonatoloog JM) een beetje de angst om alleen op grond van een echobeeld een beslissing te nemen'. 'En het is vanuit de literatuur bekend dat je je er in kunt vergissen. Ik kan mij zelf ook zo'n kind herinneren waarvan door iedereen 'vier' gezegd werd en bij obductie bleck het een 'drie.' " Dat maakt toch heel veel uit.'

Hij maakt een sprong van de twijfel van zijn collega naar de onderzoeken in de literatuur, om vervolgens zijn eigen persoonlijke ervaringen er aan toe te voegen. Repertoires hoeven elkaar dus niet uit te sluiten.

Een repertoire hoeft evenmin tot één conclusie, doorgaan of stoppen, te leiden. De neonatoloog gebruikt het gevalsrepertoire om, met een beroep op statistiek, te concluderen dat Esther een kans van $5 \%$ heeft, en pleit aldus voor verder onderzoek. Hij noemt een onderzoek dat twintig kinderen beschrijft waarvan er uiteindelijk negentien ernstig gehandicapt zijn en één matig gehandicapt. Eén van de aanwezige verpleegkundige gebruikt vervolgens echter hetzelfde repertoire en hetzelfde voorbeeld om te pleiten voor stoppen met behandelen:

'Het kind is buitengewoon moeilijk te verzorgen. Als je haar aanraakt, zie je op de monitor de waarden naar beneden vallen. Het kind is op dit ogenblik stabiel. Stabiel slecht, wel te verstaan. Maar als ik dan op lange termijn kijk, en de prognose is zo slecht als Ruud (een van de neonatologen) die zojuist heeft geschetst. dan zet ik wel mijn vraagtekens bij een verdere behandeling.'

Voor deze verpleegkundige ligt de betekenis van de onderzoeksresultaten niet in die ene hoopgevende uitzondering, die juist voor de neonatoloog de reden vormt om aan dit onderzoek te refereren, maar in die negentien andere gevallen. In haar reactie ontkoppelt zij de relatie die de neonatoloog heeft gelegd tussen de onderzoeksresultaten uit de literatuur en de twijfel over de echo als prognostisch middel. Het gebruik van een repertoire zegt op zich dus niets over het antwoord dat men geeft op de vraag 'stoppen of doorgaan?', maar alles over de redenen die men aanvoert.

Repertoires blijken ook niet aan disciplines gekoppeld te zijn. In de vergadering beperken de artsen zich niet tot het gevalsrepertoire, net zo min als de verpleegkundigen alleen maar binnen het situationele kader blijven.

Stukje bij beetje creëren de deelnemers aan de vergadering een gezamenlijk handelingstraject. ${ }^{10} \mathrm{Na}$ ongeveer vijftig minuten is er voldoende overeenstem- 
ming om tot het abstinerend beleid over te gaan en wordt de vergadering afgerond.

14.30 uur: De attending: 'Laten we afspreken dat én van de stafleden van Radiologie naar de echo kijkt en dat de kinderneuroloog geinformeerd wordt over deze casus met de vraag of hij er nog iets aan toe te vocgen heeft. Dan kunnen we daarna naar de ouders gaan.'

De arts-assistent vat het besluit samen: als de röntgenoloog dezelfde uitslag geeft zoals wij die gezien hebben en de kinderneuroloog hetzelfde beeld beschrijft zoals wij dat hebben gedaan, dan is ons advies een abstinerend beleid?' Iedereen knikt. De zitting wordt opgeheven.

15.00 uur: Op de NICU zit de verpleging aan de tafel en is bezig met de overdracht. Verpleegklappers gaan open en dicht. Aantekeningen worden met steekwoorden op kleine briefjes geschreven die vervolgens in de zak van hun uniform verdwijnen. Temidden van deze bedrijvigheid wordt Esther gedoopt. Haar moeder zit in een rolstoel naast de couveuse. De vader staat naast haar. Een priester zegt zijn gebeden. Allen gehuld in jasschort. De ouders zijn in tranen. Door het raam kijken de grootouders vanaf de gang toe. Waar anders een doopplechtigheid een groot feest is, is zij in deze omgeving het begin van het afscheid. Er worden foto's gemaakt. Voor later.

I5.45 uur: De kinderneuroloog komt de afdeling op. Naar aanleiding van de stafvergadering is hem gevraagd een neurologisch oordeel te geven over Esther. Hij buigt zich over de couveuse. 'Wat een triestheid. Wat moet ik hier nu van zeggen. Een dismatuur kind van 25 weken, daar heb ik zelf onvoldoende vergelijkingsmateriaal van. Ik weet dus niet of het kind zo reageert omdat het nog zo jong is, of dat het door de bloeding in het hoofd komt. Bovendien kan ik haar niet eens onderzoeken want dat zou ze niet kunnen verdragen. Maar als ik dit zo bekijk, wil ik wel akkoord gaan met een abstinerend beleid. Al was het maar uit humane overwegingen.' Hij wandelt naar de tafel en schrijft in de status van Esther een akkoordverklaring.

Hij schrijft dat hij akkoord gaat met een abstinerend beleid op basis van de problemen als gevolg van vroeggeboorte, een graad IV hersenbloeding, constante bloeddrukproblemen en de multi-orgaan problematiek. De rij wordt afgesloten met 'op humane gronden'. 'Alleen op basis van humane gronden, daar doen ze het niet voor. Medische redenen moeten de beslissing funderen', verklaart hij.

Hoewel de kinderneuroloog in eerste instantie de situatie vanuit een situationeel repertoire benadert, stapt hij al snel over op een gevalsrepertoire. Hoewel ik hiervoor heb laten zien dat repertoires niet aan een persoon of conclusie gebonden zijn, betekent dit niet dat ze overal even effectief zijn. Sommige redenen 'passen' beter bij bepaalde situaties." Binnen een situationeel repertoire is 
de afwezigheid van vergelijkingsmateriaal geen probleem. Een blik in de couveuse voldoet en humane overwegingen zijn voor hem doorslaggevend: 'Dit is genoeg, dit kan zo niet verder.' Terwijl dit naast de couveuse voldoende is, blijkt het situationele repertoire in de officiële context van het neurologisch verslag onvoldoende onderbouwing te bieden. De neuroloog is nu genoodzaakt om over te stappen op het gevalsrepertoire. Hiermee verandert niet zijn conclusie, maar wel de aard van de argumentatic. 'Humane overwegingen', een doorslaggevend argument in het situationele repertoire, komt als laatste in de rij. In het verslag worden medische gegevens als eerste opgevoerd ter rechrvaardiging van zijn besluit, maar zij zijn niet het resultaat van eigen onderzoek. Esthers uiterst slechte conditie laat immers geen enkel lichamelijk onderzoek toe. Bovendien ontbreekt cen referentiekader om het gedrag van een dergelijk prematuur kind te interpreteren. De neuroloog neemt daarom de gegevens uit de status over. Hiermee is de cirkel rond: er wordt een neurologisch consult gevraagd om de medische gegevens van de neonatoloog te bevestigen. De neuroloog doet dit, maar op grond van dezelfde gegevens. Hoewel hij zo geen nieuwe informatie geeft over de toestand van het kind, speelt zijn instemming met een abstinerend beleid wel degelijk een belangrijke rol.

Zoals uit mijn betoog in dit hoofdstuk is gebleken is een antwoord op de vraag 'wat te doen?' nauw verbonden met de vraag 'wat is hier het geval?' Een antwoord op deze laatste vraag vereist meer dan een simpele vaststelling van feiten. Feiten zijn op de NICU niet zozeer gegevenheden, maar worden geconstrucerd op basis van materiaal van verschillende aard, zoals woorden, getallen, handelingen en dingen. ${ }^{\text {I }}$ De staf is voortdurend gericht op het verzamelen van gegevens om de situatie van een kind te bepalen. Hierdoor groeit het kind uit van een 'geval' tot een kind met een eigen identiteit. Maar er gebeurt meer. In al het werk dat nodig is om de onbepaaldheid van het kind op te heffen, krijgt ook de afdeling zelf vorm. In dit proces worden repertoires ingezet, terzijde geschoven en samengevoegd. Hun waarde of gebruik ligt niet vast en valt evenmin samen met een bepaalde discipline, een systematisch handelingstraject of een specifiek argument.

\section{Academisch Centrum}

16.0o uur: De vierdegraads hersenbloeding wordt ook door de radioloog bevestigd. De attending en de arts-assistent bespreken opnieuw met de ouders de beslissing om Esther af te koppelen. Ook de ouders achten verdere behandeling niet zinvol en stemmen toe in een abstinerend beleid.

16.30 uur: Esther wordt van het beademingsapparaat afgekoppeld en sterft. Vervolgens wordt ze van alle slangen en draden bevrijd. De monitor valt stil. 


\section{Reisgenoten}

De opname van een kind op de NICU zet cen ordeningsproces in gang waarbij het kind volledig in de dagelijkse praktijk van de afdeling wordt ingelijfd. Maar kinderen komen zelden of nooit alleen. In hun kielzog slepen ze altijd hun ouders mee. In de praktijk betekent dit dat van de ene op de andere dag ook de ouders deel gaan uitmaken van het leven op de afdeling."

Waar het kind bij opname doorgaans rap de afdeling wordt binnen gerold, stuiten ouders echter in eerste instantic op een gesloten deur. Niemand mag zo maar de NICU binnenlopen. De kwetsbaarheid van de pasgeboren kinderen vraagt om een strenge beheersing van het afdelingskdimaat. De NICU is feitelijk één reusachtige couveuse. De temperatuur wordt constant op achtentwintig graden gehouden, de vochtigheidsgraad van de lucht dient op peil te blijven en hygiënische voorschriften worden strikt nageleefd.

De sluis vormt het overgangsgebied tussen 'de besmettelijke, koude wereld' buiten en 'de schone, warme wereld' binnen. Via overdruk en maatregelen op het gebied van hygiëne tracht men bacteriën buiten te houden. Maar er gebeurt meer in de sluis. Er vindt ook een sociale schifting plaats. ${ }^{2}$ Alleen zij die bevoegd zijn, mogen naar binnen. Deze bevoegdheid is in de regel beperkt tot het ziekenhuispersoneel en de ouders van de kinderen die op de afdeling zijn opgenomen.' De sluis is niet alleen een overgangsgebied tussen de binnen- en buitenwereld, waar mensen worden geselecteerd en bacteriën worden gebarricadeerd. Het is ook de locatie waar ouders zich opmaken voor het weerzien met hun kind. Er zijn bovendien verschillende rituele handelingen nodig, voordat ouder en kind opnieuw bij elkaar kunnen zijn. In de sluis moet men jas, tas en sieraden (notoire locaties voor bacteriën) in kledingkastjes opbergen, een jasschort over de kleding aantrekken en handen en armen grondig wassen. ' Pas dan mag men de tweede deur door en de afdeling opgaan.

Veelal amper bekomen van de schok dat hun kind niet de gezonde baby is waar ze op hadden gehoopt, treden ouders aldus de wereld van de NICU binnen. Daar staan couveuses dicht naast elkaar en van enige privacy is nauwelijks sprake. Het is in de eerste plaats een professioneel domein, waar stafleden geroutineerd hun taken verrichten. Hoe groot een NICU ook mag zijn, iedereen zit dicht op elkaar. Hier brengen staf en ouders vele uren met elkaar door. De 
sfeer kan er ontspannen zijn: verpleegkundigen die fluitend hun werk doen, ouders die met andere ouders in gesprek zijn of blij en opgelucht bij 'hun' couveuse staan. Maar het kan ook anders gaan. De context waarin staf en ouders elkaar ontmoeten is immers allesbehalve alledaags te noemen. De NICU is primair een wereld van technologie en superspecialisme, waar de zieke kinderen om wie alles draait regelmatig plotseling 'instorten'. Dan veert iedereen op en is er ineens volop activiteit en spanning: haalt het kind het? Weet het zich te herstellen? De beperkte ruimte maakt het voor de staf onmogelijk om ouders af te schermen voor onverwachte noodsituaties. De nadrukkelijke aanwezigheid van de talloze apparaten onderstreept de kriticke situatie van hun kind en roept bij ouders meestal gevoelens van angst en vervreemding op." Een onverwachts piepende en knipperende monitor doet hen het ergste vrezen, mede omdat zij niet weten hoe dergelijke signalen op de juiste wijze te interpreteren. Ook stafleden zijn niet altijd ontspannen; zij kunnen prikkelbaar zijn door vermoeidheid, frustratic over interne aangelegenheden of uit onmacht omdat de zorg en behandeling van het kind ondanks alle inspanningen niet naar wens verloopt. Door het besloten karakter van de NICU gaat deze spanning niet onopgemerkt an ouders voorbij. $\mathrm{Zij}$ zijn echter zelden vertrouwd met de op de afdeling geldende regels en gebruiken. Dit maakt het moeilijk om dergelijke momenten van spanning te interpreteren. Doen zij iets niet goed? Zitten ze in de weg of hebben ze iets verkeerd gezegd? Met het betreden van de afdeling komen ouders dus niet alleen in een ander klimaat terecht, maar ook in een andere cultuur: een afdelingscultuur met de bijbehorende zeden en gewoonten.

Ouders met hun eigen achtergrond en opvattingen en stafleden met hun specifieke regels en gebruiken treffen elkaar rond de couveuse van het kind. Via het kind zijn ouders en staf met elkaar verbonden; zolang het op de NICU verblijft, zijn zij als het ware reisgenoten. De staf heeft echter te maken met een voortdurende stroom van nieuwe reisgenoten die allemaal een eigen benadering vereisen. 'Ouders laten immers niet alles achter in de sluis; hun verwachtingen, emoties en culturele bagage nemen ze bijvoorbeeld wel degelijk mee de afdeling op. Al deze ouders moeten worden ingepast in de dagelijkse gang van zaken op de NICU en dit roept de vraag op hoe de sociale verbanden tussen ouders en staf geregeld zijn. Op welke manier hanteren de stafleden de steeds wisselende aanwezigheid van ouders? De dagelijkse organisatie van de NICU is erbij gebaat dat ouders zo snel mogelijk vertrouwd raken met de afdelingscultuur. Hoe nemen zij ouders op in het ritme? Op welke wijze worden zij deelgenoot van de sociale orde op de afdeling? Welk beeld van 'de ouder' ontstaat er uit de wijze waarop er over ouders gesproken wordt?

Om dit te kunnen achterhalen belicht ik enkele momenten waarin de wederzijdse verwachtingen onderwerp van gesprek zijn. Verwachtingen die staf en ouders over en weer van elkaar hebben, bieden een goede ingang om zicht te 
krijgen op het beeld dat er van ouders op de afdeling leeft en vice versa. Wat betrokkenen in de ogen van de ander behoren te doen, komt mede voort uit de veronderstelling wie zij zijn. Om dit beeld te achterhalen richt ik mij op situaties waarin de relatic tussen ouder en staf onder spanning staat. Hierbij wil benadrukken dat deze voorbeelden allerminst representatief zijn voor het contact tussen ouders en staf. $\mathrm{Zij}$ dienen hier echter een methodologisch doel. Juist in dergelijke grenssituaties, zoals in het eerste hoofdstuk is uitgelegd, komen wederzijdse ideeèn en visies veelal expliciet tot uitdrukking. Door deze momenten van spanning aan de hand van het begrip 'vocabulaire' te beschrijven, kan ik niet alleen onderzoeken welke sociale orde er tussen staf en ouders op de afdeling bestaat, maar ook welke mogelijkheden en beperkingen er zijn voor het oplossen van fricties die zich tussen beide partijen gedurende de opname van een kind kunnen voordoen.

\section{Wederzijdse verwachtingen}

Wie op basis van veldonderzoek greep wil krijgen op de ouder/staf relatie doet er in eerste instantic goed aan de formele, gevestigde routines te identificeren. Zo worden ouders bij hun eerste bezoek aan de afdeling opgevangen door de stafleden die op dat moment de eerste verantwoordelijkheid hebben voor de zorg en behandeling van hun kind. Deze verpleegkundige maakt hen wegwijs op de afdeling. Ouders krijgen bijvoorbeeld de basisregels uitgelegd die voor hen van belang zijn. Zoals het handenwassen bij binnenkomst en de bezoekregeling. Er wordt uitgelegd waar de draden, slangen en apparaten voor dienen die ze bij hun kind aantreffen. Niet lang daarna volgt een gesprek met de dienstdoende arts, waarin hij of zij de medische situatie van het kind op grond van de beschikbare kennis met de ouders bespreekt.

Met de opvang van ouders bij hun eerste bezoek aan de afdeling is echter niet alles voor eens en voor altijd geregeld, laat staan gezegd. Naast formele regels, zoals bezoekuren, zijn er op de afdeling ook gedragsregels die niet in de informatiefolder staan, maar die wel degelijk van kracht zijn. Het zijn verwachtingen die stafleden van ouders hebben over de wijze waarop ze met hun kind omgaan en de manier waarop ze zich in het dagelijks ritme van de NICU voegen. Ook ouders zelf hebben bepaalde ideeën over hun plaats en rol op de afdeling gedurende de opname van hun kind. Hoewel ouders vaak probleemloos de afdelingscultuur aanvoelen, ontstaat er soms bij een van de betrokken partijen ergernis en irritatie, wat weer kan uitmonden in verontwaardiging of machteloze woede en in een enkel geval zelfs kan leiden tot een onherstelbare vertrouwensbreuk. Factoren van allerlei aard kunnen hierin een rol spelen, inclusief factoren die voortvloeien uit de organisatie van de NICU, zoals de indeling en 
inrichting van de afdeling, het regionale verwijssysteem en de voortdurende roulatie van stafleden.'

In het onderstaande beperk ik mij tot die momenten waarop de andere partij niet voldoet aan hetgeen verwacht wordt. Aangezien verwachtingen meestal impliciet blijven zolang alles goed gaat, spits ik mijn analyse toe op die momenten waarop verwachtingen juist niet uitkomen.

\section{Verwachtingen van stafleden over de ouders}

Artsen en verpleegkundigen hebben meer of minder uitgesproken ideeèn over de wijze waarop ouders zich ten aanzien van de gang van zaken op de afdeling dienen te gedragen. Gezien de instabiele situatie van de kinderen die op de NICU liggen, verwacht de staf bijvoorbeeld dat ouders altijd (telefonisch) bereikbaar zijn, iets waarop in het voorlichtingsmateriaal van de afdeling expliciet wordt gewezen. Daarnaast gaan zij er in principe vanuit dat ouders zelf ook geregeld contact opnemen over de toestand van hun kind. Maar dit betekent nog niet dat er altijd ruimte is om ouders te woord te staan. Een arts-assistent uit het Academisch Centrum zegt hierover:

'De ouders mogen hier de hele dag komen. Dat is prima. Maar zij vragen ook voortdurend om aandacht. En dat is 's morgens niet te doen gezien de drukte. Je moet dan alle kinderen nakijken. Hoe is de situatie 's nachts geweest en hoe is die nu. De rest van de dag sta je er voor een groot deel alleen voor. Dat betekent veel medische handelingen doen, zoals puncteren. Tussendoor heb je overleg met je collega's en moet je van alles regelen. En dan ben je net bezig met een medische handeling en dan vragen ouders je even te spreken. Maar je spreekt niet "eventjes" met ouders en zeker niet met maar één van de ouders.

Neem bijvoorbeeld die ouders van Daan. Die zijn zo opdringerig. Die willen direct dat je helemaal voor ze klaar staat. Alsof er verder geen andere kinderen meer zijn. Ze zijn ook ontzettend eigenwijs. Ze denken alles te weten. Er valt gewoon niet met die mensen te praten. Nu willen ze hun kind mee naar huis nemen. Dat die man niet inziet dat zo'n kind niet mee naar huis kan.'

Deze arts wil ouders wel degelijk te woord staan, maar alleen als hij ook daadwerkelijk aandacht voor hen kan hebben. Ouders die verwachten dat hij direct zijn bezigheden neerlegt om hen te spreken, wekken zijn wrevel op. Ouders behoren niet de organisatie van het werk op de NICU te verstoren. $\mathrm{Zij}$ die dat wel doen worden als lastig ervaren. De irritatie van deze arts gaat daarnaast ook over ouders die denken het zelf beter te weten. Dit wordt door hem niet op prijs gesteld. Ze dienen zijn medische deskundigheid te erkennen.

Artsen en verpleegkundigen hebben niet alleen verwachtingen over het gedrag van ouders in relatie tot de staf. Ouders met een kind op de NICU beho- 
ren in de ogen van stafleden ook betrokken te zijn bij wat er met hun kind gebeurt. Dat betekent meer dan alleen de telefoon oppakken en de afdeling bellen. De staf gaat er van uit dat ouders het gemis van hun kind proberen te compenseren door frequent op bezoek te komen. Hun verwachtingen komen echter niet altijd uit. Zo vertelt een verplecgkundige in het Academisch Centrum:

'Ik heb wel eens een vader meegemaakt die maakte meer foto's van het kind ernaast, dan van zijn eigen kind. Terwijl zijn eigen kind nauwelijks twee dagen oud was. "Ja maar het is zo'n lief klein kindje", wordt er dan gezegd. Dat is gewoon belachelijk. Je ziet het ook 's avonds op de Medium Care. Dan zijn die moeders de kinderen aan het flessen en dan staan die vaders voor het raam hier de IC binnen te gluren."

Of neem die ouders van Benny. Die moeder zegt helemaal niets en raakt het kind nooit aan en die vader zit alleen maar naar de verpleging te lachen. Zij zijn voor iedereen een raadsel. Niemand krijgt contact met ze en met de maatschappelijk werkster wilden ze niets te maken hebben. Die ouders komen helemaal niet capabel over. Als je ze iets uitlegt luisteren ze nauwelijks. Die moeder heeft één keer haar zoontje vastgehouden omdat het door Jaap (een verplecgkundige JM) in haar armen werd gelegd. Maar daar wist ze eigenlijk ook geen raad mee. We hebben geen telefoonnummer van deze ouders en kunnen hen dus niet bellen wanneer er iets mis gaat. Om meer zicht te krijgen op deze ouders proberen we via de huisarts informatie los te krijgen. Maar de huisarts die ze hebben opgegeven blijkt helemaal niet te bestaan. En de verzekeringsmaatschappij die ze hebben opgegeven kent deze mensen helemaal niet. Het vermoeden bestaat dat de vader een illegale vluchteling is. Ik hou mijn hart vast als dat kind straks naar huis mag.'

Hoewel deze ouders wel dagelijks op de afdeling te vinden zijn, voldoen ze op verschillende manieren niet aan de verwachtingen van deze verpleegkundige.' Ze tonen volgens haar te weinig interesse in de situatie van hun kind en zijn niet coöperatief.

Een ander voorbeeld van verwachtingen bij staf betreft de reactie van de ouders van Anne. Zij heeft een ernstige hartafwijking en wordt direct na haar geboorte naar het Academisch Centrum overgebracht, waar ze wordt geopereerd. De hartoperatie brengt minder verlichting dan men hoopt en na enkele weken is Anne volledig uitgeput. Op een dag is haar toestand zeer kritiek en worden haar ouders gebeld. Deze weigeren echter te komen omdat ze op het punt staan om naar een feest te gaan. De staf reageert geschokt en is woedend. Als Anne enkele dagen later weer instort en iedereen het ergste vreest, zijn haar ouders onbereikbaar omdat ze in het theater zitten. De behandelend arts die hen de volgende dag opbelt met het verzoek om een gesprek, kan hen pas na grote inspanning overtuigen van de ernst van de situatie. Als enkele dagen 
daarna de hartfrequentie van Anne sterk daalt, is het voor iedereen duidelijk dat er geen hoop meer is en zij die nacht zal overlijden. Opnieuw worden haar ouders gebeld. Deze weigeren te komen, want het is midden in de nacht. De arts blijft hen echter bellen. Pas na het derde telefoongesprek besluiten de ouders naar de afdeling te komen. Ze komen net op tijd om hun kind nog in leven te zien. De hartslag van Anne is op dat moment al gezakt tot onder de twintig slagen per minuut. Op de afdeling heerst verbijstering en verontwaardiging over het gedrag van deze ouders.

Ouders die niet aan de verwachtingen van de staf voldoen, krijgen al gauw allerlei etiketten opgeplakt. ${ }^{10}$ Voorbeelden hiervan zijn: ouders die bij elk bezoek in huilen uitbarsten zijn incompetent; ouders die enthousiast zijn over het feit dat ze een manier hebben gevonden om met de situatie van hun zieke kind om te gaan begrijpen de ernst van de zaak niet; ouders die op basis van hun religieuze achtergrond een bepaalde behandeling weigeren zijn onredelijk; ouders die op de afdeling geen enkele emotie tonen hebben een psychisch probleem; ouders die boos, gefrustreerd of radeloos zijn, hebben ook een psychisch probleem; hoog opgeleide ouders denken dat ze alles weten en laag opgeleide ouders snappen bij voorbaat niet wat hen wordt verteld. "Dergelijke snelle conclusies en oordelen zijn uiteraard niet zonder risico voor de kwaliteit van de ouder/staf relatie.

\section{Verwachtingen van ouders over de staf}

Behalve dat stafleden verwachtingen hebben over het gedrag van ouders, hebben ouders ook een beeld van hun eigen rol op de afdeling en dit speelt door in de verwachtingen die zij van de staf hebben. Zich meestal volop bewust van de kritieke situatic van hun kind, verwachten ouders dat de staf hen op de hoogte houdt over de toestand van het kind, waarbij vooral gesprekken met de behandelend arts door ouders als zeer belangrijk worden ervaren. De staf in zowel het Academisch Centrum als het Northeastern General Hospital onderschrijft het belang van een goede communicatie met ouders. Ouders mogen dan ook altijd bellen om te vragen hoe het met hun kind gaat, al is het midden in de nacht. "In de praktijk zijn er twee piekuren voor dergelijke telefoongesprekken: vlak voordat ouders gaan slapen gaan en 's morgens vroeg na het opstaan. De verwachting dat de staf de ouders informeert kan een bron van spanning worden als ouders het gevoel krijgen dat ze buiten de besluitvorming worden gehouden. Hoewel de staf ouders op de hoogte houdt, wil dit niet zeggen dat de hoeveelheid geleverde informatie voor iedereen voldoende is. Eén van de ouders in het Academisch Centrum beklaagde zich over gebrek aan informatie: 'Ze vertellen je nauwelijks iets hier. Dat klopt toch niet. Het is nota bene ons kind." 
Ouders beoordelen stafleden niet alleen op de hoeveelheid informatie die ze krijgen, maar ook op de wijze waarop zij worden geïnformeerd. ${ }^{4}$ Een verkeerde woordkeus, een paternalistische toon of onnodig gebruik van medisch jargon zijn hiervan voorbeelden. Wat echter de ene ouder als eerlijk beschouwt, kan door een ander als lomp worden uitgelegd. Op de NICU van het Northeastern dient een ouderpaar een klacht in over een van de arts-assistenten. De moeder:

\section{"Hij gaf eerst een heleboel medische informatie en toen zei hij opeens: "Maar we} zijn er niet zeker van of uw kind het zal halen." Dat is het enige wat ik daarna nog hoorde in mijn hoofd. We vonden het zo bot dat hij dat zei. Alsof wij dat niet wisten. Natuurlijk houd je er rekening mee dat zoiets kan gebeuren. Dat zweeft ergens in je achterhoofd. Maar daar hoeft zo'n ventje je niet aan te herinneren. We zijn daarna direct naar de attending gegaan om ons beklag te doen. Niet atleen voor ons, maar ook voor andere ouders na ons. Zulke dingen zeg je niet.'

Behalve verwachtingen over de wijze waarop de staf met hen omgaat, hebben ouders ook ideeën over de manier waarop de staf met hun kind zou moeten omgaan. Veel ouders spreken de hoop uit dat hun kind behandeld en verzorgd wordt door een ervaren deskundige, die het kind goed kent en bij wie het zich prettig zal voelen. In een enkel geval zijn ouders bang dat hun kind te weinig aandacht krijgt. De ouders van Lisette, bijvoorbeeld, zijn ontevreden over de mate waarin de staf zich om hun kind bekommert. Lisette is in het Academisch Centrum opgenomen omdat ze een hartafwijking heeft. Wegens plaatsgebrek wordt zij eerst op de acute hartbewaking gelegd. Daar krijgt ze steeds de volledige aandacht van één verpleegkundige. Na overplaatsing naar de NICU moet Lisette deze aandacht echter delen met het kind in de couveuse ernaast. De ouders zijn ontstemd over deze gang van zaken en betichten de staf van onverantwoordelijk gedrag. De verpleegkundigen vinden dat de ouders veeleisend zijn en overdreven reageren. Ook voelen zij zich in hun professionele eer aangetast. Deze wederzijdse afkeuring heeft de verstandhouding tussen de ouders van Lisette en de staf geen goed gedaan.

Hoge verwachtingen van ouders over de mogelijkheden van de medische professie kunnen eveneens aanleiding geven tot spanningen. Een verpleegkundige in het Academisch Centrum:

'Je hebt ouders die liever een prematuur kindje hadden omdat die er zo leuk lief uitzien en zoveel aandacht van ons krijgen. Ze hebben geen besef van wat er werkelijk aan de hand is. Zijn er ook niet bang voor. Dan zeggen ze: "Hier kunnen ze alles. Je legt ze gewoon in een couveuse en dan groeien ze vanzelf." Die mensen die weten niet wat ze zeggen.' 


\section{Zoals ook een arts in het Northeastern General Hospital aangeeft:}

'Het probleem met veel ouders is dat ze niet begrijpen hoe moeilijk het is om te weten wat er aan de hand is en hoe de conditie van het kind zich zal ontwikkelen. Ze komen hier op de afdeling en zijn zo onder de indruk van alle technologie dat ze denken dat we alles kunnen. Ze denken dat we doordat we meer kunnen opsporen, ook meer kunnen doen.

De invloed van televisie is enorm groot. Ze kijken naar een serie en binnen een uur is alles opgelost. Dat het er in de realiteit anders aan toegaat willen ze niet geloven. Dat je hier pas na dagen bloeduitslagen binnen hebt en soms dan nog niet precies weet wat er aan de hand is, kunnen ze niet geloven. Je bent dan een slechte dokter en dan willen ze een ander. Ze laten zich helemaal misleiden door de technologische verpakking waar ze hun kind in vinden. Alsof we alles kunnen. Soms moet je doorgaan omdar de ouders dat willen. Ongeacht de hopeloze situatie van het kind. De wet verbiedt het ons om hier tegen in te gaan. Maar als ouders willen dat we stoppen omdat hun kind niet perfect is en wij zien daar de zin niet van in, dan gaan we door. Dan hebben de ouders dat maar te accepteren."

Gevoed door de medische soaps ontstaat er, volgens deze arts, een beeld van handelende artsen die altijd precies weten wat er aan de hand is en wat ze moeten doen om het kind van een wisse dood te redden. Het bijbehorende 'happy end' onderstreept het idee dat vandaag de dag alles mogelijk is. In dit beeld heeft de arts een almacht die lang niet altijd waargemaakt kan worden. Wanneer de arts niet duidelijk kan maken wat het kind heeft, eisen ouders soms dat een andere arts de behandeling overneemt. In een enkel geval willen zij hun kind mee naar huis nemen. Als niemand hen kan vertellen wat hun kind heeft, is er blijkbaar niets mee aan de hand.

Verschillende factoren zijn aldus een voedingsbodem voor verbazing, ergernis, grote verontwaardiging en misplaatste verwachtingen. Allerlei spanningen kunnen een wig drijven tussen staf en ouders. In het ergste geval ontstaat er een onherstelbare breuk in het vertrouwen van ouders. Dit komt zelden voor, maar als het gebeurt is het voor beide partijen een dramatische gebeurtenis die vaak in de collectieve herinnering van een afdeling voortleeft."

\section{Wederzijdse beeldvorming}

De hierboven beschreven voorbeelden maken duidelijk hoe de wederzijdse verwachtingen direct verweven zijn met de situatie van het kind op de NICU. Het bijzondere karakter van de sociale interactie op de NICU kleurt niet alleen de verwachtingen die de betrokkenen van elkaar hebben, maar geeft ook direct betekenis aan wie zij zijn. De professionele identiteit van artsen en verpleegkundigen wordt deels geconstrueerd door hun relatie met het kind, terwijl de rol 
van de ouders in zekere zin geheel door de relatie met hun kind wordt bepaald. " Er zijn niettemin verschillende manieren waarop in de context van de NICU de relatic tussen ouder en kind gedefinieerd wordt, en daarbij zijn verschillende vocabulaires in het geding." We kunnen deze verschillende vocabulaires nader bepalen door de verwachtingen van artsen en verplecgkundigen ten aanzien van ouders te analyseren. I $k$ bespreek twee voorbeelden: de verwachting dat ouders op bezoek komen en dat zij bereikbaar zijn.

In het eerste geval, de verwachting dat ouders op bezock komen, wordt de relatic tussen kind en ouder gedefinieerd in termen van emotionele binding. Of in de woorden van één van de verpleegkundigen uit het Northeastern: 'Voor ons als verpleegkundigen geldt een holistisch perspectief van de baby met de ouders. Zij horen bij elkaar. Zij zijn een geheel.' Samen met hun kind vormen ouders de cenheid van zorg en aandacht van de staf: de ouders maken deel uit van de patiëntenconstellatie. De behandeling van het kind en de aandacht voor de ouders hangen nauw met elkaar samen. Men spreekt over ouders als object van zorg en men doet dit in termen van wat kan worden aangeduid als een psychosociaal vocabulaire."

In het tweede geval, de bereikbaarheid, wordt er op een andere wijze over ouders gesproken. Hier gaat het vooral over informatie-uitwisseling en beslissingen. Er lijkt sprake van een soort contract: "wij (artsen) houden jullie op de hoogte, maar dan moeten jullie (ouders) wel bereikbaar zijn." Anders gezegd: het recht op informatie geeft de plicht tot bereikbaarheid. Het idee dat ouders op de hoogte worden gehouden en betrokken dienen te worden in het besluitvormingsproces geeft een bepaalde invulling aan de ouder-kind relatie. Het kind mag dan onder de hoede van de staf zijn gebracht, desondanks blijven de ouders degenen die het voor het zeggen hebben. Ook ouders zelf spreken zich in dergelijke bewoordingen uit: "Ze vertellen je niets hier. Het is notabene ons kind". Het is en blijft het kind van de ouders met alle bijkomende rechten en plichten, ongeacht waar het zich bevindt. In deze wijze van spreken verschijnt de ouder als drager van ouderlijke macht. Hierbij gaat het vooral over rechten en plichten. De taal die hierbij wordt gebezigd, behoort tot een juridisch vocabulaire.

Het gebruik van uiteenlopende vocabulaires behelst meer dan louter een verschil in woordkeuze. Woorden hebben in verschillende vocabulaires andere betekenissen." Door de toepassing van een bepaald vocabulaire wordt een werkelijkheid gecreëerd waarin mensen, dingen, feiten, waarden en handelingen een eigen plaats en betekenis krijgen toebedeeld. ${ }^{20}$ Mijn analyse van de gehanteerde vocabulaires is dan ook niet gericht op de vraag of de woorden de werkelijkheid juist weergeven, maar op welke wijze zij vorm geven aan de werkelijkheid. In de verschillende vocabulaires ontstaan niet alleen definities van wie en wat ouders zijn, zij geven eveneens de mogelijkheden en beperkingen aan van de gedeelde aanwezigheid van ouders en staf op de afdeling - van hun gedeelde 
rol als reisgenoten." Vocabulaires worden gemunt in bepaalde disciplinaire domeinen. Tijdens het gebruik van verschillende vocabulaires kunnen overeenkomstige repertoires worden ingezet. Binnen een psychosociaal vocabulaire kan men zowel een gevalsrepertoire als een siruationeel repertoire hanteren. Ook binnen een juridisch vocabulaire kan men beide repertoires gebruiken. Vocabulaires en repertoires staan dus in een matrixverhouding tot elkaar: binnen elk vocabulaire (psychosociaal of juridisch) kunnen beide repertoires (situationeel en gevals) worden ingezet om de praktijk te ordenen. Dit wil niet zeggen dat alleen repertoires de handelingspraktijk actief ordenen. Ook vocabulaires geven vorm aan de handelingspraktijk waarin ze worden gebruikt." In het vervolg van dit hoofdstuk zal ik de ordenende kracht van beide vocabulaires onderzoeken.

\section{De ouder als object van zorg}

In de door het psychosociale vocabulaire opgebouwde werkelijkheid speelt het welzijn van ouder en kind een vooraanstaande rol. Een belangrijk element hierin is uiteraard de noodzakelijke ziekenhuisopname van het kind. De hieruit voortvloeiende scheiding tussen ouder en kind verstoort hun 'normale' relatie." Om de overlevingskansen van het kind te optimaliseren wordt het doorgaans onmiddellijk na de bevalling naar de afdeling neonatologie gebracht, als het ziekenhuis tenminste over zo'n afdeling beschikt. ${ }^{4}$

Een illustratief geval is Robert, bij wie direct na de geboorte een fatale hartafwijking wordt ontdekt. Snel ingrijpen is geboden, maar het ziekenhuis beschikt niet over een NICU. Zijn moeder vertelt:

'Ik was zo blij toen Robert werd geboren. De arts zei: 'gefeliciteerd, u heeft een zoon. Alles zit erop en eraan.' Terwijl ze dat zei knipte zij de navelstreng door en we zagen Robert zo wegglijden. Hij werd helemaal blauw. Ze hebben hem toen direct bij mij weggehaald. Ik had het allemaal niet zo door wat er gebeurde. Ik werd gewoon naar de kraamafdeling gebracht en was in de veronderstelling dat Robert wel zo bij me gebracht zou worden. Ik zat notabene al beschuit met muisjes te eten toen me verteld werd dat hij niet meer in het ziekenhuis lag, maar al onderweg was naar het Academisch Centrum. Mijn man bleek er met mijn schoonvader achteraan gegaan te zijn, maar de ambulance reed zo hard dat ze hem niet bij hebben kunnen houden. En ik wist van niets. Ik wist helemaal niet dat er iets ergs aan de hand was. Ik ben ook zo geschrokken toen me werd verteld dat hij een ernstige hartafwijking had. Ik kon het haast niet geloven. Ze hadden van tevoren gezegd dat zijn hart goed was. Dat hadden ze tijdens de zwangerschap op de echo gezien. Gelukkig maar, want als we het van tevoren hadden geweten had ik zo'n gespannen zwangerschap gehad. Nu hebben we geluk gehad dat er snel werd gehandeld." 
Een plotselinge opname op de NICU van een ander ziekenhuis versterkt de scheiding tussen ouders en kind, omdat zij altijd later ter plekke arriveren en dan niet weten wie hun kind is. Een arts of verpleegkundige zal hen dit moeten vertellen. Deze omstandigheden bemoeilijken het opbouwen van een band met het kind.

Ook de ouders van Esther krijgen hun kind op deze wijze 'toegewezen'. Haar moeder:

Nadat de beslissing was gevallen ben ik direct onder narcose gebracht. Twintig minuten later was Esther geboren. $\mathrm{Zij}$ is direct naar de afdeling overgebracht. Ik heb haar zelf pas uren daarna gezien. Ze brachten mij met bed en al naar de afdeling. Maar ik moet je zeggen dat het mij de eerste keer weinig deed. Je moet je voorstellen, je wordt dan naar een couveuse gebracht en ze zeggen 'daar ligt je kind'. Ja, het zal wel zo zijn. Je moet ergens vanuit gaan, maar ik voelde geen enkele binding. Het was zo klein en ik kon het niet zo goed zien omdat her bed niet tot helemaal naast de couveuse gereden kon worden. Je moet niet vergeten dat ik nog maar een zwangerschap van pas zevenentwintig weken achter de rug had. Pas de tweede keer toen ik haar zag, brak er iets in mij door. Ik kon toen net met mijn hand de couveuse in en stak haar voorzichtig mijn vinger toe. Esther knelde daar direct haar handje omheen. Ze deed daarna ook heel even haar oogjes open. Dan gaat er wel wat door je heen.'

Dat het kind uit haar buik en het kind in de couveuse één en dezelfde waren, kan de moeder zich maar moeilijk voorstellen. Hoewel zij het kind maanden bij zich heeft gedragen, moet zij het zich weer opnieuw vertrouwd maken. In dit geval draagt de reactie van Esther duidelijk bij tot het emotionele contact dat haar moeder met haar aangaat.

Omdat de tere conditie van een pasgeboren kind het verloop van de behandeling een onvoorspelbaar karakter geeft, zijn ouders vaak bang voor een slechte afloop. Deze angst kan hen ervan weerhouden zich aan het kind te hechten. Gevoelens van teleurstelling over de afloop van de zwangerschap of verdriet en schuldgevoelens over dat ze geen gezond kind ter wereld hebben gebracht bemoeilijken het aangaan van een relatie met het kind. ${ }^{2}$ Niet elk kind is bovendien in staat te reageren op de aanwezigheid en affectie van de ouder; het is mogelijk te ziek of te gesedeerd om te kunnen reageren. Rituelen zoals een doopplechtigheid kunnen ertoe bijdragen dat de distantie doorbroken wordt. De vader van Esther:

'Het ging steeds slechter met Esther. Je zag haar wel vechten maar toen kreeg ze die hersenbloeding. We hebben haar toen 's middags laten dopen. Dat was heel moeilijk omdat het opeens veel meer 'Esther' werd. Het werd een individu.' 
Door dit ritueel kreeg Esther meer een eigen plek in de familie en ging zij meer deel uitmaken van de familiegeschiedenis.

In het psychosociale vocabulaire geldt de opname op de NICU als een verstoring van het natuurlijke hechtingsproces tussen ouder en kind. In de cerste plaats zijn ouders gescheiden van hun kind. In de tweede plaats hebben ze niet het gezonde kind gekregen waarop ze hadden gehoopt. Dit 'dubbele verlies' plaatst ouders in een rouwproces met bijkomende reacties als verbijstering, ongeloof, boosheid, emotionele onthechting of berusting. Een ouder met een kind op de NICU is een ouder die steun en begeleiding nodig heeft. De staf is zich doorgaans terdege bewust van de moeilijke positie waarin ouders verkeren, maar door hun werkzaamheden kunnen zij nict altijd voldoende aandacht aan ouders geven." Zoals een verpleegkundige vertelt:

'We moeten steeds meer medische handelingen doen, zoals infuus inbrengen. arterieel bloed afnemen. Dat doen wij allemaal. We doen tegenwoordig van alles. Een arts kijkt je gek aan als je vraagt of zij het willen doen. Alleen de residents ${ }^{*}$ willen het nog wel doen, want dan kunnen ze oefenen. Maar dit alles maakt wel dat wij het steeds drukker krijgen en daar zijn de ouders de dupe van. Het is heel frustrerend wanneer je merkt dat je steeds minder tijd voor ouders hate ar out steculs vaker kortar reageert. Dat is niet goed."

De verpleegkundige verwijst naar de ouders als deel van de patiëntenconstellatie: kind plus ouder. In tegenstelling tot het kind hebben ouders in het psychosociale vocabulaire geen medisch probleem, maar een psychosociaal probleem dat om een psychosociale oplossing vraagt. Ouders zijn als het ware "second order patients." Naast de behandeling van de pasgeborenen neemt de begeleiding van ouders een belangrijke plaats in op de afdeling. In de praktijk zijn het met name verpleegkundigen die ouders steun en begeleiding geven. $\mathrm{Ze}$ instrueren hen over de verzorging van hun kind, maken hen wegwijs op de afdeling, informeren hen in alledaagse taal over de toestand van het kind en zijn hun steun en toeverlaat. Waar artsen de autoriteit op het gebied van het kind zijn, gaan verpleegkundigen over de ouders." Zij zijn op dit terrein specialist: the emotional managers:"

Op basis van het psychosociale vocabulaire kunnen ouders snel gemedicaliseerd worden. Men is bijvoorbeeld niet zozeer geneigd te spreken van opzettelijk wangedrag, maar van verward gedrag. In dit vocabulaire zijn ouders niet recalcitrant, maar ontkennend. Niet agressief, maar bang. Door op deze wijze over ouders te spreken wordt schuld en verantwoordelijkheid buiten de ouder gelegd. De staf is zo meer tolerant voor afwijkend gedrag van ouders. Zelfs ouders die niet bij hun kind op bezoek komen, worden in dit vocabulaire niet direct afgewezen: geen desinteresse, maar angst voor verlies doet ouders thuisblijven. Uit angst dat hun kind alsnog zal overlijden trekken ouders zich soms 
terug. $\mathrm{Zij}$ ervaren een emotionele band als bedreigend. In een psychosociaal vocabulaire is dit "coping through distance'."

In een psychosociaal vocabulaire spelen niet alleen emoties een rol, maar ook de sociale achtergrond van ouders. Er bestaat in dit opzicht een groot verschil tussen de populatie ouders op de NICU van het Northeastern General Hospital en die op de NICU in het Academisch Centrum. Anders dan in het Academisch Centrum is in het Northeastern ten tijde van het onderzock een groot deel van de ouders zeer jong (tieners), niet of nauwelijks opgeleid, verslaafd, of levend onder de armoedegrens, of het gaat om een alleenstaande moeder." Een grote diversiteit in sociaal-culturele achtergronden gaat meestal gepaard met een veelheid aan opvattingen en gewoonten, wat aanleiding kan zijn tot misverstanden tussen ouders en stafleden. Om deze voor te zijn maakt de staf een inschatting van de sociale achtergrond van ouders en kiest een bijpassende stijl van communiceren. Hierbij spelen factoren als klasse, etniciteit en opleidingsniveau cen belangrijke rol. De invloed van de sociale achtergrond reikt echter verder dan de wijze van communiceren. De sociale stabiliteit van ouders is soms ook van invloed op het ontslagmoment van het kind en op de afweging of de behandeling wel of niet moet worden voortgezet."

De keuze voor her gebruik van een, oguchosocial. vacahulaien jeshter. niet altijd 'passend' in deze context." Het spreken over ouders in een psychosociale vocabulaire kan de tolerantie van staf ten aanzien van de ouders vergroten en zo eventuele spanning neutraliseren. Maar dit lukt alleen als ook de ouder zich in de bijbehorende rol kan vinden. Sommigen zien zichzelf liever niet als object van zorg; zij ervaren goedbedoelde zorgzaamheid als badinerend of discriminerend. Stafleden die ouders in psychosociale termen als zorgbehoevend, als patiënt definiëren, creëren een ongelijkheid in de onderlinge relatie. Op deze manier schuilt in het psychosociale vocabulaire een zeker paternalisme.

Ook de omgekeerde situatie kan tot fricties leiden. Wanneer ouders in een psychosociaal vocabulaire over zichzelf spreken, dient de staf tot op zekere hoogte mee te gaan in dit vocabulaire. Maar dit gebeurt niet altijd. De moeder in het Northeastern bijvoorbeeld voelde zich niet erkent in haar psychische nood als de arts haar vertelt dat hij er niet zeker van is dat haar kind het zal halen. Met een verwijzing naar haar psychische belasting en die van andere ouders, kwalificeert de moeder de uitspraak van de arts als ongepast en dient zij vervolgens een klacht in. Dit voorbeeld laat tevens zien dat het gebruik van het psychosociale vocabulaire niet altijd op de aanwezigheid van mildheid en begrip duidt. Het wordt ook ingezet om juist uitdrukking te geven aan boosheid en frustratie. In het geval van de irritatie bij de staf over het feit dat de ouders van Anne niet naar de afdeling willen komen, blijkt dat psychosociale terminologie niet samenvalt met tolerantie. De staf beschouwt het handelen van deze ouders niet in termen van angst voor een naderend verlies, maar spreekt over egoïsme en liefdeloosheid. 
Een ander aspect van het psychosociale vocabulaire dat bijdraagt tot fricties heeft te maken met het feit dat de staf het ook als ontsnappingsroute voor kritiek kan inzetten." Negatieve geluiden van ouders over het functioneren van de staf kunnen onschadelijk worden gemaakt door ze af te doen als een uiting van emotioncle verwarring. Ontevreden ouders zijn dan niet boos, maar in de war. Op deze wijze wordt kritiek geneutraliseerd. Ouders kunnen echter het gevoel krijgen dat ze niet serieus genomen worden en zullen zich nog sterker gaan afzetten. Ook de inschatting van de sociale achtergrond van ouders brengt risico's met zich mee. Het kan ertoe bijdragen dat ouders in ongelijke mate in de besluitvorming worden betrokken." Ouders kunnen zich dan buitengesloten voelen en zich tegen de staf keren.

Ondanks het feit dat er zich situaties voordoen waarin het psychosociale vocabulaire zelf spanning genereert, creëert dit vocabulaire een sociale orde waarin zorg een belangrijke plaats inneemt. De bijdrage van dit vocabulaire aan de kwaliteit van het samenzijn van de reisgenoten bestaat er over het algemeen in dat staf en ouders geneigd zijn om op basis van begrip en tolerantic op gedrag van de ander in te spelen. Hierdoor kunnen problemen in de ouder/staf relatic eenvoudiger worden opgelost. Het juridisch vocabulaire gaat een stap verder: het is primair gericht op een zo helder mogelijke afbakening van de rollen zodat problemen uitblijven.

\section{De ouder als drager van ouderlijke macht}

Het juridisch vocabulaire brengt een andere sociale orde op de NICU aan. Het heeft betrekking op de rechten en plichten van de betrokkenen, het nemen van besluiten, overleg en onderhandeling, en de invulling van officiële documenten. In dit vocabulaire wordt niet aan elke inbreng hetzelfde gewicht toegekend. Zo weegt de stem van ouders in het besluitvormingsproces zwaar: de ouder is in de eerste plaats drager van ouderlijke macht en verantwoordelijkheid. In het juridisch vocabulaire is de ouder niet afhankelijk en hulpbehoevend, maar een autonome, geïnformeerde gesprekspartner in de besluitvorming.

Het juridisch vocabulaire beoogt het verkeer tussen ouders en staf duidelijk te regelen. Belangrijk hierbij is het begrip informed consent. Dit betekent dat ouders voor bepaalde handelingen toestemming moeten verlenen, zoals het uitvoeren van een ingreep waar bepaalde risico's aan vastzitten. Om zulke beslissingen te kunnen nemen moeten ouders geïnformeerd worden door de arts." De informed consent regeling verplicht stafleden om ouders duidelijk uit te leggen wat het doel, de aard en de consequentie van de voorgenomen handeling is. Op basis van deze informatie nemen zij een beslissing. Informed consent verzekert ouders van een stem in het beslissingsproces. 
Waar in het psychosociale vocabulaire het contact van de staf met ouders voornamelijk via de verpleegkundigen verloopt, neemt binnen de orde van het juridisch vocabulaire de arts deze taak op zich. Dit wordt duidelijk zichtbaar bij twijfel over de zin van het continueren van de behandeling. Voordat wordt besloten een behandeling te staken vindt er overleg plaats tussen arts en ouders. Hoewel een dergelijk besluit onder de verantwoordelijkheid van de arts valt, dienen de ouders erbij betrokken te worden." Zonder hun instemming gaan artsen niet over tot het staken van een behandeling.

In het Northeastern General Hospital is de handtekening van ouders op een niet-reanimatic formulier een belangrijke factor in de besluitvormingsprocedure. In de Verenigde Staten is de kans groot dat onvrede van pariënten of verwanten uitmondt in een juridisch proces." In het Northeastern neemt het juridisch vocabulaire dan ook een meer prominente plaats in dan op de NICU van het Academisch Centrum. Dit vocabulaire mag ouders en staf dan in overlegsituaties samenbrengen, maar het garandeert geen overeenstemming over de beslissing. Ouders kunnen het bijvoorbeeld oneens zijn met het voorstel van de artsen om de behandeling te staken en de staf verzoeken door te gaan met behandelen. Aangezien ouders een belangrijke plaats in het besluitvormingsproces wordt toegekend, komt de staf veelal aan dit verzoek van ouders tegemoet. Een ervaren nurse-practitioner uit het Northeastern vertelt over de dilemma's die hierbij een rol spelen het volgende:

'Tegenwoordig kijken we niet meer naar gewicht en weken. Elk kind wordt gewoon behandeld, ongeacht hoe jong en klein het is. Er zijn soms ouders die willen dat we doorgaan terwijl het al voor iedereen duidelijk is dat het kind gaat sterven. De wet verbiedt ons om hier tegen in te gaan. Soms zijn ze zelfs al half blauw. Maar ouders ontkennen dit en weigeren een DNR formulier* te tekenen. Dan zet ik mijn verstand op nul en doe wat er van mij verlangd wordt. Want op dat moment doe ik het kind geen goed meer. Dus draai ik een knop om en richt me heel bewust op de ouders. Ik doe her dan voor hen en probeer hen te helpen. Dat is de enige manier om dat te doen.

Er is veel veranderd. Vroeger haalden we de kinderen wel van het beademingsapparaat af. 'Laat het gaan', was het devies. Maar dat kan nu niet meer als gevolg van de wetgeving. De wetgeving is bedoeld als bescherming, maar het is eerder een wapen, een gevaar voor de kinderen. Je moet maar doorgaan. Het kind krijgt nauwelijks de kans om te sterven.'

Anders dan in het Academisch Centrum is in het Northeastern het juridisch vocabulaire sterk verweven met wettelijke regelgeving. De juridische bemoeienis in het Northeastern is mede het gevolg van een aantal gevallen in de Verenigde Staten waarin men had besloten om de behandeling te staken. De BabyDoe case uit de jaren tachtig is in dit opzicht een geruchtmakend voorbeeld. ${ }^{*}$ 
Artsen besloten in dit geval in overleg met de ouders om het kind, dat was geboren met het syndroom van Down" in combinatie met een slokdarmafsluiting, niet verder te behandelen. De commotie die op dit besluit volgde bracht de regering van Reagan ertoe om de zogenaamde 'Baby-Doe Regulation' op te stellen om herhaling te voorkomen. Deze juridische regels moesten het medisch besluitvormingsproces bewaken en de arts op het juiste spoor houden. Als gevolg hiervan is medisch handelen sterk verankerd in wettelijke bepalingen. De mogelijkheid dat behandelingen ook in een juridische context worden beoordeeld, heeft van medisch ingrijpen meer een vorm van strategisch handelen gemaakt." Deze juridische druk heeft geleid tot een praktijk, waarin nauwelijks ruimte is voor het achterwege laten van een behandeling of het staken van een reeds ingezette behandeling.

Wettelijke regels dicteren echter lang niet altijd op ondubbelzinnige wijze de besluitvormingspraktijk op de NICU. Het juridisch vocabulaire waarin de regels zijn vervat, is allesbehalve waterdicht. Wat gebeurt er bijvoorbeeld als ouders artsen verzoeken om de behandeling te staken op basis van redenen die voor de medische staf als onvoldoende worden beschouwd? Een verpleegkundige uit het Northeastern zegt hierover:

'In de praktijk gebeurt het zelden dat een kind een DNR-code* krijgt. Pas als een kind niet levensvatbaar is, worde de behandeling gestaakt. Ouders hebben hier het eerste recht. Maar als ouders willen dat artsen stoppen omdat hun kind niet perfect is en de arts ziet daar de zin niet van in, dan gaan we gewoon door met behandelen en hebben ouders dit te accepteren. Gelukkig komt dit zelden voor.'

Deze verpleegkundige verwijst naar de mogelijkheid om ouders de beslissingsbevoegdheid te ontnemen. Dit is juridisch inderdaad mogelijk: ouders worden dan niet meer als gesprekspartner beschouwd, maar als partij waartegen het kind dient te worden beschermd. Bepaalde omstandigheden kunnen dus de beslissingsmacht in andere handen doen overgaan, al is dan lang niet altijd duidelijk in wiens handen die terecht komt. Het is niet ongewoon dat de betrokkenen heel verschillende ideeën over de locatie van de beslissingsmacht hebben. Ook al baseren betrokkenen zich op hetzelfde vocabulaire, garandeert dit nog niet dat er overeenstemming bestaat over wie welke rechten en plichten heeft en waar precies de grenzen van macht en verantwoordelijkheid liggen.

\section{Het is de arts die beslist}

De consternatie rond de behandeling van Maureen in het Northeastern General Hospital is een goed voorbeeld van deze problematiek. Zij wordt geboren na drieëntwintig weken zwangerschap. Onderzoek wijst uit dat zij een omvangrijke vierdegraads hersenbloeding aan beide zijden van het hoofd heeft. In de 
ogen van de betrokken verpleegkundigen heeft dit kind geen enkele kans op overleven en dient de behandeling gestaakt te worden. De attending heeft echter aangegeven dat wat hem betreft een abstinerend beleid niet aan de orde is, omdat een hersenbloeding op zich geen dodelijke aandoening is. Bovendien, zo heeft hij verklaard, kan men zelfs niet met zekerheid zeggen dat dit kind gehandicapt zal zijn. Er zijn immers een paar gevallen bekend waarvan de uitkomst minder ernstig was dan verwacht. Dit betekent dat men in de praktijk niets kan zeggen over de uitkomst van een graad vier bloeding.

\section{Northeastern General Hospital}

n.oo uur: Maureens hartactie daalt herhaaldelijk tot onder het kritisch niveau.

De verpleegkundige is voortdurend bezig om haar hart te stimuleren. De verplecgkundige die haar verzorgt heeft grote twijfel. 'Dit soort kinderen maakt dat ik vanavond gefrustreerd naar huis ga. Het heeft geen zin om dit kind te behandelen. Mar toch blijven de artsen doorgaan. Ze voelen zich meer safe als ze alles hebben gedaan. Bovendien is het erg herösch om te kunnen zeggen dat je hier drieèntwintig weekers behandelt. Ik hoop dar het snel afgelopen is. Je stopt heel veel energie in dit kind terwijl het een hoofd vol bloed heeft. Ik sta hier emotioneel niet achter, dus je begrijpt hoe ik me voel als ik vanavond thuiskom. Dit kind is zo triest. Overal waar ik haar aanraak gaat de huid kapot. Ze heeft nog maar 23 weken zwangerschap achter de rug. Ze had hier nog helemaal niet moeten zijn. Vind je het gek dat ze er steeds tussenuit probeert te knijpen. Dat lijkt me de enige gezonde reactie die dit kind nog kan opbrengen. Een kind voelt dat, weet je. Het weet wanneer het zich terug moet trekken. Elke keer probeert ze weer dood te gaan. Maar ik moet steeds ingrijpen want ze heeft nog geen DNR-code gekregen.

Maar ik verwacht dat Frank (de attending neonatoloog JM) straks met de ouders gaat praten en dat het dan snel afgelopen is. Ik ken Frank. Hij onderhandelt niet met ouders. Hij vertelt hen dat het afgelopen is en dat ze nog een gelegenheid hebben om afscheid te nemen van hun kind. Ik vind dit goed want sommige ouders willen maar dat je doorgaat.'

II.30 uur: De attending doet zijn dagelijkse ronde. 'Hoe gaat het hiermee?' De verpleegkundige doet haar verslag over de voortdurende brady's van Maureen. De attending bekijkt uitgebreid de bloeduitslagen en de gegevens van de monitor. Zijn gezicht klaart op: 'De saturaties zijn zo slecht nog niet gezien haar toestand. Volgens mij hebben we hier helemaal niet te maken met ordinaire brady's. Daar zijn haar saturaties te hoog voor. Hier moet iets anders aan de hand zijn. Dit lijkt meer op een afwijking van het hart dan een slechte conditie. Koppel haar ook aan een andere monitor, dan krijgen we andere informatie. Dit moeten we uitzoeken.' De verpleegkundige is perplex, maar zegt niets. De attending draait zich om en wandelt naar de volgende couveuse. 
Geen gesprek met de ouders, geen afronden van de behandeling. In tegendeel, de behandeling wordt geintensiveerd. Naarmate de dag vordert gaat de conditie van Maureen sterk achteruit en is de attending voortdurend bij haar couveuse te vinden. Hij balloneert, spuit stimulerende middelen in, laat verschillende bloedtesten doen en houdt de monitor in de gaten. Maureen krijgt de ene hartstilstand na de ander, maar de attending weet haar elke keer weer terug te halen. De verpleegkundigen op de unit zien hern druk doende bezig. In hun ogen doet dit kind er alles aan om te sterven, maar maakt hij dat haar onmogelijk.

\section{Het zijn de ouders die beslissen}

Ook andere artsen en verpleegkundigen spreken over Maureen. Zij lokaliseren de beslissingsmacht echter op een andere plaats: bij de ouders. Voor hen zijn het de ouders van Maureen die het verloop van de behandeling bepalen. De artsassistent die ook verantwoordelijk was voor de behandeling van Maureen verdedigt dan ook de attending:

'Hij (de attending JM) heeft al een paar keer getracht met de ouders te praten over het staken van de behandeling, maar deze weigeren met hem in gesprek te gaan. Ze verlieten de afdeling en zijn nooit meer teruggekomen. Ze blijven nu weg omdat ze weten dat ze dan gevraagd worden een DNR-formulier te tekenen. Zolang het kind geen officiële DNR-code heeft, moeten wij wel doorgaan. Maar deze mensen (de ouders JM) hebben zo'n irrealistisch beeld van wat er aan de hand is. Ze denken dat het altijd zo'n lief klein kind blijft. Maar het is duidelijk dat ze er helemaal niers van snappen. Ze hadden het over een kleine bloeding in het hoofd en dat hun kind geen wiskundewonder hoeft te zijn. Als het straks vrolijk rondhuppelt zijn ze ook tevreden. Alsof er hier iets te huppelen valt.'

Voor deze arts-assistent ligt de beslissingsmacht helemaal niet bij de attending, maar bij de ouders. In haar ogen heeft de attending het uiteindelijk ook niet voor het zeggen. Hem treft dan ook geen blaam. Het zijn de ouders van Maureen die volgens haar verantwoordelijk zijn voor de situatie. De arts-assistent schetst deze ouders niet alleen als onrealistisch, maar ook als onwillig. Zij zijn niet bereid om te praten, laat staan te tekenen. Op deze manier wordt het de staf onmogelijk gemaakt om de behandeling van Maureen te staken. Een andere arts-assistent neemt het echter voor de ouders op.

'Ik begrijp die ouders heel goed. Ik vind ook dat er alles op alles gezet moet worden om dit leven te redden. Je mag niet zomaar een leven afbreken. Dat is het doden van leven. Ik kan me dus ook niet voorstellen dat iemand het in zijn hoofd haalt een zwangerschap af te breken. Dat kan je niet doen.' 
Hoewel de arts-assistenten een verschillend oordeel hebben over de beslissing, lokaliseren zij allebei de beslissingsmacht bij de ouders van Maureen. Weer andere verpleegkundigen plaatsen hier kanttekeningen bij. Eén van hen:

'Ik heb gehoord dat Frank (de attending JM) de ouders zou hebben verteld dat hun kind een bloedinkje heeft en dat er nog vijftig procent kans is dat het als een normaal kind opgroeit. Je begrijpt dat zij door het positieve beeld dat ze van Frank voorgeschoteld hebben gekregen, eisen dat alles op alles wordt gezet. Uit die hoek hoeven we dus ook niets te verwachten.'

Voor deze verpleegkundige zijn de ouders van Maureen geen onrealistische, ontkennende ouders of beschermers van pasgeboren leven, maar ouders die verkeerd voorgelicht zijn. Zij zijn het slachtoffer van misleiding. Deze ouders kunnen dan ook niet verantwoordelijk gesteld worden voor het feit dat de behandeling wordt gecontinueerd. Deze verantwoordelijkheid ligt in de ogen van deze verpleegkundige wel degelijk bij de attending. Hij is het die maar doorgaat en de ouders vertelt dat het allemaal wel meevalt.

\section{Het is de wet die beslist}

De eerste arts-assistent heeft echter de almacht van de arts ook afgezwakt door op de consequenties van de DNR-regeling te wijzen. 'We moeten wel doorgaan zolang dit kind geen DNR-code heeft.' Het zijn in haar ogen de juridische structuren die het staken van de behandeling onmogelijk maken. Hiermee wordt de beslissingsmacht op een andere plaats gelokaliseerd, namelijk in de wet.

In het Northeastern worden artsen tot bepaalde handelingen aangezet door de structuur die het juridisch vocabulaire met zich meebrengt. Zo moet de behandelend arts de ouders van een kind wiens behandeling wordt gestaakt een DNR-formulier voorleggen met het verzoek dat te ondertekenen. Voor de attending die in het Northeastern met ingang van de nieuwe maand de dienst van haar collega overneemt, is dit een vraag die je ouders eigenlijk niet mag voorleggen. De tweede attending:

'Ik wil de ouders de ellende besparen een DNR te tekenen. Het is alsof je vraagt of ze het doodvonnis van hun eigen kind willen tekenen. (...) Ik vind dat je dit een ouder niet aan kunt doen. Om die reden haat ik de DNR regeling. Het is een goede regeling voor artsen en ik ben er blij mee. Maar ik vind het onmenselijk om aan ouders te vragen een handtekening te zetten. Het lijkt zo simpel, maar het is zo symbolisch.'

Niet de arts of de ouders worden hier verantwoordelijk gesteld voor de situatie waarin het kind verkeert, maar de wet. Juridische regels vormen hier een stevig netwerk en bevatten een bias in het voordeel van behandelen omdat er voor het 
staken van de behandeling getekend moet worden. Het DNR-formulier blijkt een actor die een eigen logica in zich draagt en die - in dit geval - het abstineren bemocilijkt.

De handelingspraktijk rond het DNR-formulier kan niet alleen het beëindigen van de behandeling problematiseren, maar ook het contact met ouders. Op het eerste gezicht lijkt een DNR-formulier enkel een instrument dat levensbečindigend handelen bij pasgeborenen regelt. Voor het staken van de behandeling moeten staf en ouders een bepaald handelingstraject volgen. In dit traject geldt de handtekening van ouders op het DNR-formulier als een cruciale stap. Met deze handtekening onderschrijven zij heel concreet de beslissing dat de behandeling van hun kind beèindigd wordt en weten zij zich verzekerd van een stem in het besluitvormingsproces. Maar deze ouderlijke macht, concreet gemaakt in de handtekening op het DNR-formulier, lijkt voor Maureens ouders eerder een belemmering om hun kind te bezoeken, dan een bevestiging van hun inspraak. Als de eerste attending aangeeft dat hij met hen wil praten, verlaten zij de afdeling om vervolgens nooit meer terug te komen. De DNR-regeling, een middel ter bescherming van de uitoefening van ouderlijke macht, draagt hier bij aan het ouderlijk onvermogen en vergroot het wantrouwen bij de ouders ten aanzien van de communicatic met de arts.

Hoewel de artsen kunnen volstaan met een mondelinge toezegging van de ouders van Maureen dat reanimatic achterwege gelaten kan worden, blijven de verpleegkundigen verplicht om in te grijpen zolang er geen handtekening van haar ouders op het DNR-formulier staat. Juist dit gegeven leidt tot onrust, onduidelijkheid en verontwaardiging bij de verpleging wanneer bij het ingaan van de volgende maand de nieuwe attending wel besluit de behandeling te beëindigen, maar 'niet meer dan' een mondelinge toezegging van de ouders via de telefoon regelt. Hoewel alle partijen, inclusief Maureens ouders, op dat moment het erover eens zijn dat men in geval van nood niets meer zal ondernemen om Maureen 'terug te halen', zijn de verpleegkundigen juridisch gezien nog steeds verplicht om in te grijpen. Voor de verpleging is er met betrekking tot het reanimatiebeleid ten aanzien van Maureen totaal niets veranderd. $\mathrm{Zij}$ bevinden zich nog steeds in de juridische gevarenzone en moeten gewoon doorgaan met reanimeren. Voor één van de verpleegkundigen is dit niet meer op te brengen. Voortzetting van de behandeling veroorzaakt in haar ogen slechts zinloos lijden; desondanks moet zij elke keer het kind reanimeren als het dreigt te sterven. Om trouw te kunnen blijven aan haar persoonlijke morele overtuiging besluit zij de verzorging van Maureen over te dragen aan een collega."

Het beleid over de behandeling van Maureen lijkt geheel te zijn bepaald door de structuren die met de juridisch regels mee de afdeling opkomen. Maar is dat wel zo? Dit geval laat zien dat juridische structuren de beslissingsmacht op één enkel punt lokaliseren, maar dat hiermee nog niet vastligt waar of bij wie de 
macht is gelokaliseerd. In het Northeastern lokaliseren de afzonderlijke betrokkenen de beslissingsmacht op verschillende plaatsen. Voor de verpleegkundige die de eerste dag voor Maureen zorgt ligt deze geheel bij de arts. Anders dan de arts-assistent, ziet deze verpleegkundige helemaal geen arts die met zijn rug tegen de muur staat, gevangen in een web van juridische regels, maar een arts die altijd zijn eigen plan trekt. Desgevraagd wordt dit door deze arts bevestigd:

'Als ik met een behandeling wil stoppen, stop ik. Ongeacht wat de ouders hiervan vinden. Als ik verdere behandeling zinloos vind, stop ik ermee. Niemand wil kinderen behandelen die een vegetatief leven tegemoet gaan. Dus als ik een behandeling wil staken, dan doe ik dat ook. Zelfs als de ouders willen dat ik doorga. Ik ben tenslotte verantwoordelijk voor de patiënten en mijn eigen handelingen. Wanneer ouders het niet met mij eens zijn, verzamel ik de opinie van de vier andere neonatologen en laat dat op een formulier vastleggen. Dus als ouders mij een rechtszaak aan willen doen, laat ze maar komen. Ik heb immers al vier medische experts achter mij staan. Dus ze maken geen enkele kans. Maar meestal komt het niet zover. Meestal bereid ik de ouders voor op het feit dat er niets meer is wat we kunnen doen.'

Deze neonatoloog is wars van elke juridische druk. Ook het feit dat de tweede attending in het geval van Maureen de behandeling niet direct staakt, wordt door een verpleegkundige aan andere factoren toegeschreven dan aan het feit dar de toestemming van ouders ontbreekt of de druk van de juridische regels. De verpleegkundige denkt dat er psychische factoren in het spel zijn: 'Ik denk dat ze het moeilijk vindt. Maar wij hebben deze kinderen zo gemaakt. En nu ze niet zijn zoals we ze gehad hadden willen hebben, wil niemand zich er meer mee bemoeien.' Deze verpleegkundige legitimeert deze houding in een psychosociaal vocabulaire. Ook de tweede attending zelf kiest een psychosociaal vocabulaire om haar besluit uit te leggen:

'Gisterennacht had ik een nachtmerrie over dit kind. Dus besloot ik een dag te wachten voordat ik haar van de beademing af zou halen. Ik moet er zelf ook mee kunnen leven, nietwaar. Het is een belasting elke keer weer. Je voelt het heel diep in jezelf. Het is niet niks. Dus om die reden heb ik ermee gewacht.'

Deze artsen gaan elk op hun eigen manier met de wettelijke kaders om. Dit betekent niet dar de wet voor hen niet bestaat. Zij houden wel degelijk rekening met de juridische regels, maar bepalen zelf hoe ze ermee omgaan. De tweede attending doet dit bijvoorbeeld door via omtrekkende bewegingen bepaalde regels te vermijden. Ze schuift de vraag om een handtekening zo lang mogelijk voor zich uit in de hoop dat dit op een bepaald moment niet meer nodig is. Is een kind eenmaal terminaal, dan volstaat immers een mondelinge toezegging van de ouders. Op deze manier probeert zij ouders te ontlasten. Ook de eerste 
attending zoekt op zijn manier naar een oplossing. Mogen ouders zich tegen zijn beslissing keren, dan zal hij overgaan tot het verzamelen van gespecialiseerde medestanders om zijn juridische positie te versterken.

Het gebruik van eenzelfde (in dit geval juridisch) vocabulaire kan de spanning rond Maureen niet voorkomen. Sterker nog, de praktische orde rond de behandeling van dit kind raakt volledig ontwricht. Als het gebruik van één vocabulaire geen sociale orde kan garanderen, dan zal een combinatie van vocabulaires zeker tot spanning leiden en zo de praktische orde ondermijnen. Immers, spreken over de ouder als een object van zorg staat op gespannen voet met de ouder die beslissingen moet nemen en hiervoor een handtekening onder een document moet zetten." Deze spanning komt voort uit de verschillende prioriteiten van de vocabulaires. In het juridisch vocabulaire staat de zeggenschap van ouders voorop. Meepraten betekent meebeslissen en als zodanig ook medeverantwoordelijk zijn. In de wereld van het psychosociaal vocabulaire heersen andere waarden. Ouders dienen gesteund en zelfs beschermd te worden. De ouder heeft in zijn rol als medepatiënt geen autoriteit; als dragers van ouderlijke macht worden zij echter voor onmogelijke beslissingen geplaatst. Het samengaan van beide vocabulaires lijkt onmogelijk.

\section{Rivaliserende vocabulaires?}

Laten we teruggaan naar het Academisch Centrum. Anders dan in het Northeastern houdt men hier stafvergaderingen over dit soort beslissingen. Een analyse van het verdere verloop van de stafvergadering over Esther laat zien hoe de staf de ouderlijke macht tracht te waarborgen zonder ouders alleen te laten in hun beslissing. Hieruit blijkt dat een samengaan van twee vocabulaires wel degelijk mogelijk is, en zelfs zonder dat het de praktische orde ondermijnt. Daarom eindigt de stafvergadering niet nadat het besluit over het kind is genomen, maar komt eerst nog de positie van de ouders aan de orde. 'Hoe bejegenen we de ouders van dit kind? Welke verantwoordelijkheid kunnen we bij hen leggen waar het deze beslissing betreft?' In de stafvergadering over Esther leidt de aanwezigheid van beide vocabulaires eerst tot een dilemma, om vervolgens een oplossing mogelijk te maken. In de vergadering lukt het de staf een positie te vinden waarin de ouderlijke macht gewaarborgd blijft, terwijl de belasting voor de ouders wordt geminimaliseerd. Welke manoeuvres zijn noodzakelijk om uiteindelijk op deze positie terecht te komen? 


\section{Wie beslist?}

Centraal in de stafvergadering over Esther staat de vraag of het beter is om de behandeling van Esther te staken gezien haar slechte prognose. Naarmate de consensus over het abstinerend beleid toeneemt, komen de ouders van het kind meer en meer op de voorgrond te staan; om vervolgens zelf onderwerp van discussie te zijn.

\section{Academisch Centrum}

De maatschappelijk werkster wijst op de situatic van de ouders van Esther. 'Ik denk dat het voor die ouders heel belangrijk is dat er geen twijfel meer is. Dat zij niet het gevoel hebben dat zij nu opnieuw moeten kiezen. Dan is het zo dat jullie eigenlijk al een keuze hebben gemaakt.'

Voor de arts-assistent gaat dit te snel. 'Nou ja, je adviseert. Of $z e$ het nu wel of niet zo vinden, de ouders zullen als laatste de beslissing moeten nemen over wat er moet gebeuren. Wij kunnen niet beslissen. Dat zullen zij toch moeten doen. We kunnen wel zeggen dat we dit voorstel hebben. Maar dan moeten zij toch beslissen wat ze daar mee gaan doen.'

De neonatoloog: 'Wat mij betreft ligt het iets subtieler.'

'Ja, de praktijk is altijd wat subtieler', beaamt de arts-assistent.

Het psychosociale vocabulaire staat hier tegenover het juridische vocabulaire. Een gevoel van solidariteit met de ouders doet de maatschappelijk werkster naar het psychosociale vocabulaire grijpen, waarin de ouder als object van zorg fungeert. Dit vocabulaire laat echter geen enkele ruimte voor de beslissing van de ouders. Ouders ontlasten wordt hierin gelijkgesteld aan ouders niet laten beslissen. De beslissingslast komt hiermee volledig bij de staf te liggen. In reactie hierop schuift de arts-assistent alle last weer terug in de richting van de ouders: de staf kan deze beslissing niet nemen. Dat moeten ouders zelf doen.

\section{Academisch Centrum}

De maatschappelijk werkster: 'En wie gaat er met de ouders spreken?'

De attending knikt van nee. 'Ik ken ze niet. Jij kent de ouders toch, Margreet?'

De arts-assistent knikt. 'Ja ik heb een paar keer met de ouders gesproken. Oké, dus als de röntgenoloog dezelfde uitslag geeft zoals wij die gezien hebben en de kinderneuroloog hetzelfde beeld beschrijft zoals wij dat hebben gedaan, dan is ons advies een abstinerend beleid?'

De attending: 'Ja, als iedereen zich daar in vinden kan?'

De neonatoloog: 'Ik voel me niet erg gelukkig met de term 'advies'. Ik denk dat je duidelijk naar de ouders moet zijn dat de prognose heel slecht is. Wat ik net zei, dat 19 van de 20 kinderen ernstig mentaal motorisch gehandicapt zijn. Ik vind dat dat de harde feiten zijn." 
De attending: 'Ja, en dan zullen de ouders je ook vragen, "ja dokter en wat nu?" Je kunt niet zeggen, "meneer, u heeft zoveel kansen dat het niet goed gaat en zoek het maar uit." De ouders zullen jou dan vragen, "ja dokter, wat vind u daar dan van?" Ik vind het onvoldoende om de ouders te vertellen hoeveel kans er is dat ze een gehandicapt kind krijgen. Ik vind dat ouders verwachten dat je hen een advies geeft. Dat zullen we dan moeten formuleren.'

De maatschappelijk werkster probeert de aversie van de neonatoloog te begrijpen. 'Maar Ruud, jij zegt dat je niet zo gelukkig bent met de term 'advies'. Bedoel je dan dat je toch bij de ouders neerlegt dat ze moeten kiezen?'

'Ja, ten dele wel ja. Al zullen we ze dat zo niet zeggen. Dat gaat in zo'n gesprek natuurlijk iets subtieler dan als wij dat hier zo hard plaatsen. Ik denk dat er een zekere keuze van hen moet uitgaan."

De attending: 'I ben het dus fundamenteel niet met jou eens. Ik vind dat als je het zo brengt dat de ouders een keuze moeten maken, dat we toch een bijzonder zware last op de schouders van die ouders laden. Het risico zit er in dat welke keuze ze ook maken ze dat zich altijd zullen blijven verwijten. Ik denk dat wij ze bijna dwingend moeten adviseren, c.q. de keuze maken, zo van "meneer en mevrouw, hier is echt niets meer aan te doen." Zodat die ouders niet zelf met die last opgezadeld worden.'

Van enig raakpunt tussen de vocabulaires is op dit moment van de vergadering geen sprake. Deze oppositie is echter voor geen van de betrokkenen wenselijk. Het verbreekt het collectief dat de staf en ouders van Esther met elkaar rond de couveuse zijn geweest en zet de betrokken partijen tegenover elkaar op een moment dat eenheid geboden is.

Zoals we eerder zagen bij de ouders van Maureen, komen de ouders van Esther nu in het juridisch vocabulaire in verschillende hoedanigheden naar voren. Ook tijdens de stafvergadering gaat het over ouders als beslissers die een meer dan wel minder actieve positie in het besluitvormingsproces kunnen innemen. In het eerste geval nemen ouders actief deel aan het besluitvormingsproces, terwijl zij in het tweede geval 'louter' hoeven in te stemmen met de keuze die de staf reeds heeft gemaakt." Ondanks dit verschil, delen deze posities het uitgangspunt dat ouders meebeslissen. Dat is immers hun recht.

Het recht op meebeslissen mag een prominente plaats hebben in het juridische vocabulaire, in het psychosociale vocabulaire gelden andere waarden. Op basis van het psychosociale waardesysteem worden dergelijke beslissingen als belastend gekwalificeerd. Het zou ouders alleen laten in hun beslissing. Spreekt en denkt men meer in juridische termen over ouders, dan wordt een dergelijke opmerking als neerbuigend afgedaan. Met de waarden van het juridische vocabulaire voor ogen wordt het verborgen paternalisme van het psychosociale vocabulaire bekritiseerd. De overstap naar een ander vocabulaire betekent dus 
tevens de overstap naar een ander waardesysteem. In het psychosociale vocabulaire staat het contact tussen verpleegkundigen en ouders voorop. In dit vocabulaire zijn ouders afhankelijk en emotioneel, en ligt de beslissing bij de arts; dit laatste om ouders te beschermen. Het juridisch vocabulaire legt echter meer beslissingsmacht bij de ouders en de wet neer. In dit vocabulaire zijn ouders autonoom, geïnformeerd en - op sommige momenten - gelijkwaardig aan de artsen. Zo kent elk vocabulaire zijn eigen hiërarchie en waardesysteem en brengt elk vocabulaire zijn eigen (sociale) orde in de handelingspraktijk aan. Het definieert omgangsvormen, crečert meer of minder ruimte voor solidariteit of respect, en verdeelt beslissingsmacht. Spreken in een andere taal is ook meten met een andere maat. Is een compromis wel mogelijk?

De staf probeert via de distributie van autoriteit (juridisch vocabulaire) en sympathie (psychosociaal vocabulaire) het contact met ouders in goede banen te leiden. Met de aanwezigheid van twee botsende waardesystemen lijkt de doelstelling om ouders tot steun te zijn én hun ouderlijke macht te blijven erkennen echter onhaalbaar. Desalniettemin blijft men in de stafvergadering over Esther zoeken naar die coördinaten, waarop ouders in deze beide hoedanigheden recht kan worden gedaan. Naarmate de stafvergadering vordert, lukt het de betrokkenen steeds beter om tot elkaar te komen. Hiervoor worden de verschillende vocabulaires met elkaar gecombineerd. In het voorstel van de attending om de ouders een 'dwingend advies' te geven, wordt de situatie weliswaar in juridische termen gepresenteerd, maar de concrete uitvoering ervan impliceert dat het uiteindelijke besluit tegelijkertijd op de schouders van de ouders rust en door de staf gedragen wordt. Daarnaast neemt de neonatoloog die het juridisch vocabulaire hanteert steeds meer elementen uit het psychosociale vocabulaire over. 'Ze moeten kiezen' wordt 'er moet een zekere keuze vanuit gaan'. 'Dwingend adviseren' wijzigt zich vervolgens via 'een advies' in 'dat ze akkoord gaan met een keuze van ons'. Langzaam maar zeker weten de aanwezigen een compromis te sluiten tussen de twee vocabulaires:

\section{Academisch Centrum}

De neonatoloog: 'Ik ben het er mee eens dat we niet die volledige keuze naar die ouders toe moeten schuiven. Dat ze zich door ons gesteund moeten weten. Maar ergens moeten ze ook weten dat ze akkoord gaan met een keuze van ons.'

'Dat is wat anders', stemt de attending in.

'Je begrijpt: het ligt allemaal heel subtiel naast elkaar', vervolgt de neonatoloog. 'Ergens moeten ze mee in stemmen, want we kunnen niet de beademing stoppen zonder dat ze daarmee instemmen.'

De attending: 'Dat klopt, maar ik vind dat het handelen zo moet zijn dat de ouders achteraf niet met schuldgevoelens komen te zitten, ongeacht de beslissing die er uit voortrolt. Zo moet je het inkleden.' 
juridisch vocabulaire sluit naadloos aan bij deze sociale orde: het lokaliseert de beslissingsmacht op één punt. Eén persoon draagt de uiteindelijke verantwoordelijkheid. In het Academisch Centrum is de institutionele orde geen kwestie van een één op één relatie, maar van gezamenlijkheid: de verantwoordelijkheid voor de behandeling en de zorg ligt bij een team van artsen en een team van verpleegkundigen. Deze sociale orde van gezamenlijkheid staat haaks op de individualiteit die het juridisch vocabulaire uitdraagt. Mengen met het psychosociale vocabulaire, dat het belang van solidariteit voorop stelt, biedt de mogelijkheid om een nieuwe manier van spreken te creëren die aansluit bij de institutionele orde van gezamenlijkheid. Dit geeft hen de mogelijkheid de verantwoordelijkheid van de beslissing op meerdere schouders te leggen.

Het juridisch vocabulaire creèert een orde waarin overleg met ouders plaatsvindt en formulieren worden ingevuld. Dit betekent niet dat alleen het juridisch vocabulaire over macht gaat, want ook het psychosociale vocabulaire gaat gepaard met onderlinge ongelijkheid. Evenmin betekent het dat alleen het psychosociale vocabulaire over bescherming gaat; dit geldt evenzeer voor het juridisch vocabulaire. Deze beschermt rechten in plaats van gevoelens. De verschillende vocabulaires ordenen de sociale werkelijkheid van de NICU op uiteenlopende wijzen. Waar het ene vocabulaire de rollen verdeeld op basis van emoties, doet het andere vocabulaire dat op basis van rechten en plichten. Waar in het ene vocabulaire de staf tegenover ouders en kind staat, hebben staf en ouders in het andere een gezamenlijk belang ten opzichte van het kind. Op de afdeling blijkt er aldus niet één sociale orde te heersen, maar bestaan meerdere ordes naast en door elkaar. Dit biedt staf en ouders de mogelijkheid tot onderhandeling. In een

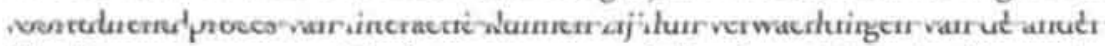
bijstellen en nuanceren. Het bestaan van verschillende sociale ordes die met de vocabulaires worden ingebracht, kan aanleiding zijn tot misverstanden of zelfs tot spanning. Maar in de dynamische en organische verwevenheid van deze vocabulaires - zij liggen historisch gezien niet vast - schuilt ook de ruimte voor flexibiliteit en discussie. Staf en ouders hebben elkaar immers nodig in de zorg voor het kind. Het is in ieders belang, en dat van het kind in het bijzonder, dat zij zich in deze situatie niet tegen elkaar keren. Ouders en staf staan in een relatie van afhankelijkheid tot elkaar en zij zetten dan ook verschillende strategieën in om te voorkomen dat één van beide partijen voortijdig afhaakt.

Het gedeelde belang van staf en ouders ligt in hun gezamenlijke doelstelling: het herstel van het kind. Dit herstel is allerminst vanzelfsprekend. Het leven op de NICU kenmerkt zich - meer nog dan dat in de buitenwereld - door voortdurende strijd en onvoorspelbare veranderingen. Het leven op de NICU is vanaf het eerste moment op extreme wijze onzeker. Het is aan de staf deze grilligheid in goede banen te leiden. Hoe zij dit doen en wat daarbij de problemen zijn, is het onderwerp van het volgende hoofdstuk. 


\section{Een onzeker traject}

De NICU-staf dient steeds adequaat in te spelen op de regelmatig en vaak onvoorspelbare veranderingen in de toestand van het kind in de couveuse. Veranderingen in de toestand van het kind zijn bovendien zelden eenduidig. In de eerste plaats is 'verandering' een signaal van het ogenschijnlijk eenvoudige feit dat het kind 'leeft'. Zoals elk pasgeboren kind groeit ook het kind op de NICU na de geboorte verder. Dit is uiteraard een essentiële ontwikkeling. Wanneer het kind echter te klein of te ziek is om deze natuurlijke groei zelf te bewerkstelligen, zal zonder ingrijpen van buitenaf zijn conditie snel achteruitgaan. Verandering impliceert dan niet langer 'groei', maar 'levensbedreiging' en direct handelen is noodzakelijk. In de tweede plaats kan een verandering het effect zijn van behandeling en vaak betekent dit 'herstel'. Maar de kinderen op deze unit reageren lang niet altijd goed op cen behandeling; het gaat altijd slechts om een poging het verloop van de gebeurtenissen zodanig te beinvloeden dat de conditie van het kind zich in positieve richting beweegt. Al is een groot deel van dit werk routine en zal een ervaren staf zich niet zo snel laten verrassen, toch blijven zich steevast situaties voordoen waarin onzekere factoren de boventoon voeren. In die zin behoudt 'verandering' op de NICU altijd een element van 'onzekerheid'.

Onzekerheid is een karakteristiek element van de medische praktijk als geheel.' Anders dan in de medische leerboeken is de dagelijkse handelingspraktijk minder overzichtelijk. In het geval van de individuele patiënt kunnen bepaalde klinische kenmerken ontbreken of is er sprake van diverse aandoeningen die op elkaar inwerken. ${ }^{2}$ Een ervaren arts kan in een bepaalde situatie toch grote twijfels hebben over de te nemen stap, omdat hij geen tijd heeft om op een uitslag te wachten, er geen protocol voorhanden is, of omdat een instrument onnauwkeurig of onbetrouwbaar is. Een arts moet echter handelen, ook in de afwezigheid van zekere kennis.

Op de NICU is de factor onzekerheid in vele vormen aanwezig. Slaat de behandeling aan of niet? Stort een kind in als gevolg van hartproblemen of een longinfectie? Moet men het protocol loslaten omdat het kind zich anders gedraagt dan verwacht? Een reeks aan elkaar gerelateerde problemen kan de conditie van een kind volledig destabiliseren. Het is niet altijd duidelijk wat een 
kind aan het 'doen' is, waar het zich op het behandelingstraject bevindt en in welke richting de situatie zich gaat ontwikkelen. Er kan bovendien twijfel rijzen over de juistheid van de onderzoeksgegevens, de betrouwbaarheid van de apparatuur of het vermogen van de ouders om met de situatie om te gaan.

Hoewel onzekerheid een belangrijke component is van medische kennis op de NICU, betekent dit niet dat de staf in de dagelijkse praktijk voortdurend gebukt gaat onder de druk ervan. Artsen beschikken over een arsenaal aan strategieën om onzekerheid het hoofd te bieden: ze houden een slag om de arm, denken in termen van waarschijnlijkheid, benoemen het als thema van wetenschappelijk onderzoek, consulteren anderen, besluiten om geen beslissing te nemen, of ze proberen door humor of ironie hun onvermogen te relativeren.' Op de werkvloer wordt de onzekerheid die altijd samengaat met medische kennis gecompenseerd door de suggestie van 'controle', die het handelingspatroon van de arts kenmerkt. Routines, klinische ervaring, praktische vaardigheden en een zekere voorraad kennis dragen allemaal bij tot een houding waarin de arts overgaat tot handelen, zoals hij dat 'gewoon' is te doen.' Redenerend op basis van 'gezond verstand' en met een pragmatische instelling zoeken artsen hun weg door de dagelijkse beslissingen en handelingen, doorgaans in het volle besef dat er geen volledige controle over het verloop van een behandeling bestaat.

Op het moment dat cen behandeling wordt gestart, gaat het dan ook niet zozeer om de oplossing van een probleem, maar om de opening van een handelingstraject. De staf kan het traject niet geheel overzien, al is het doel - een gezond kind dat naar huis kan - wel van meet af aan duidelijk. Het is echter niet op voorhand gegeven of en hoe de staf hierin zal slagen. Vanwege de grensverleggende situaties die zich bij de behandeling van kinderen op de NICU nogal eens voordoen, betreden artsen soms schimmige gebieden waar routines ontbreken en zich onvoorziene gebeurtenissen voordoen.

In dit hoofdstuk staat de vraag centraal hoe de staf omgaat met het spanningsveld tussen de noodzaak tot verandering en interventie enerzijds en de daaraan gekoppelde onzekerheid en risico's anderzijds. Hoe trachten artsen het kind op koers te houden en de twijfels om te zetten in 'zekere' kennis en controle? Ik zal dit illustreren aan de hand van twee gevallen, de behandelingstrajecten van Tom en Robert.' Het gaat in beide gevallen niet om een routinebehandeling en zij laten dan ook zien in welke gedaantes onzekerheid in de neonatologiepraktijk voorkomt, op welke wijze de onzekerheid het behandelingsproces problematiseert en welke strategieën worden ingezer om de vastgelopen behandeling weer vlot te trekken. Hierbij spelen tijd, richtlijnen, apparaten en getallen een belangrijke rol. Overigens zal blijken dat elke strategie om met onzekerheid om te gaan, ook zelf weer nieuwe problemen met zich meebrengt. 


\section{De bepaling van het handelingstraject}

De keuze van het handelingstraject is van groot belang voor het al dan niet succesvol afronden van een behandeling. Vanwege de grote kwetsbaarheid van de kinderen die op de NICU worden opgenomen, is doortastend ingrijpen vaak van levensbelang.' Bij de poging van de staf om de toestand van een kind in de hand te houden zijn twee factoren in het geding: tijd en richtlijnen.

\section{Tijd als risico en als bondgenoot}

De keuze voor een bepaald handelingstraject is van groot belang voor het vervolg van het leven van de pasgeborene. De noodzaak tot het maken van een keuze doet zich echter meestal voor op een tijdstip dat een arts het minste zicht heeft op de situatie van het kind: hij ziet het kind voor het eerst of er is slechts weinig informatic beschikbaar.' Toch moet er een beslissing worden genomen over een handelingstraject. Artsen vallen hierbij terug op de verhaalstructuur van medische kennis.' Artsen 'lezen' het lichaam alsof het een verhaal is. Zij interpreteren, sorteren en combineren wat zij horen en zien en proberen daar een medisch verhaal in te ontdekken. Om wijs te kunnen worden uit de veelheid aan details gebruiken artsen niet alleen wetenschappelijke medische kennis; als ervaren lezers van het lichaam gebruiken zij ook hun kennis van de plot van soortgelijke medische verhalen. Bekendheid met de plot vergroot de kans op de herkenning van de aandoening.

Het belang van de herkenning van de aandoening ligt niet zozeer in de definiëring van het ziektebeeld, maar in het handelingsperspectief dat daaruit voortvloeit.' Op basis van de diagnose maakt de staf zich een voorstelling van wat zich op handelingsniveau aandient: de handelingen die verricht moeten worden, de volgorde waarin dit moet gebeuren, de middelen en mensen die hierbij moeten worden ingezet en de mogelijke effecten van de interventies." Anders dan in de medische boeken lopen op de afdeling de handelingen die gericht zijn op diagnose en therapie van meet af aan door elkaar heen. Dit is bijvoorbeeld zichtbaar bij de opname van Tom: de staf gaat direct aan de slag. Diagnostische en therapeutische handelingen worden tegelijkertijd verricht in plaats van na elkaar."

Diagnostische testen bevestigen vermoedens en bieden duidelijkheid. Deze testen vergen echter tijd. Tijd die er niet altijd is. In acute gevallen heeft een arts geen tijd om eerst uit te zoeken wat er met het kind aan de hand is, maar ook dan dient er te worden gehandeld. De verantwoordelijke arts moet een traject kiezen op basis van onvolledige kennis. Aangezien zo'n besluit niet zonder risico's is, kiest een arts niet alleen voor een behandeling, maar ook - en misschien wel juist - voor het type risico dat hij wil lopen. ${ }^{2}$ De arts die aanwezig is bij de 
geboorte van Robert staat voor een dergelijke keuze. Na de geboorte lijkt in eerste instantie alles met hem in orde. Maar op het moment dat de arts de navelstreng doorknipt, wordt het kind helemaal blauw. De arts heeft geen informatie over de oorzaak hiervan, maar moet onmiddellijk iets doen om het kind in leven te houden. Zij probeert niet eerst zelf een diagnose te stellen, maar kiest direct voor opname op een gespecialiseerde afdeling in een ander ziekenhuis. Op deze manier tracht zij het risico van overlijden te vermijden. De opname op de NICU van het Academisch Centrum blijkt Roberts redding. Vanuit een perifeer ziekenhuis wordt hij met de babylance* naar de NICU gebracht. Alles is voor zijn ontvangst in gereedheid gebracht. Er staat een open couveuse klaar met bijbehorende apparatuur en ook de kindercardioloog is van zijn komst op de hoogte gebracht. Bij aankomst wordt hij direct door de cardioloog onderzocht. Op het scherm van het Doppler-apparaat* is duidelijk te zien hoe het zuurstofrijke bloed direct weer terugstroomt naar de longen. Over de transpositie* is geen enkele twijfel. Zonder een operatieve correctie heeft een kind met een transpositic geen enkele kans op overleven. Bij een dergelijke ingreep bestaat er geen middenweg: het lukt wel of het lukt niet. Als de operatie slaagt, is het rendement maximaal. Het kind kan dan opgroeien als een volledig gezond kind.

Gezien de complexiteit van het traject dat zich in het geval van Robert aandient, is een gedegen voorbereiding noodzakelijk en die kost tijd. Robert verkeert echter in een acute situatie, wat betekent dat er tijd gemaakt moet worden. Dit gebeurt door middel van medicatie die het sluiten van de ductus* vertraagt. Door de ductus open te houden kan het zuurstofrijke bloed toch nog de rest van het lichaam bereiken. Door de keuze voor deze medicatie dwingt de staf alsnog tijd af om het vervolg van het traject te kunnen voorbereiden.

Soms heeft de staf meer tijd ter beschikking om uit te zoeken wat er aan de hand is bij een moeilijk te diagnosticeren kind. Men gaat dan aan de slag om bepaalde onzekere factoren uit te schakelen. De arts wijzigt bijvoorbeeld de medicatie of de instelling van een apparaat om te zien hoe het kind daarop reageert. Behandelen is in zo'n situatie eerder een kwestie van 'proberen en afwachten' dan van het doelgericht inzetten van middelen." De methode van 'proberen en afwachten' is een veel gebruikte strategie in de geneeskunde om onzekerheid het hoofd te bieden. De staf heeft geen zekerheid over het aanslaan van de behandeling, maar wordt door de situatie gedwongen iets te doen. Er wordt een 'experimentele' ruimte gecreëerd, waarin niet de staf maar het kind aan zet is. De staf heeft gehandeld en vervolgens moet blijken of en hoe het kind reageert.

Een andere manier om onzekerheid of twijfel voor een bepaalde tijd uit te schakelen is verwijzing naar de toekomst: een beslissing hoeft nog niet genomen te worden. Soms kan zij nog niet genomen worden, omdat alle noodzakelijke informatie bijvoorbeeld nog niet beschikbaar is. Dit is een veelvoorkomende reden voor het uitblijven van actie. 


\section{Academisch Centrum}

De arts-assistent heeft het vandaag zwaar bij de visite. De attending blijft doorvragen. Met éen van de kinderen weer de assistent nog niet zo goed wat te doen. Het is voor hem nog onvoldoende duidelijk wat er met het kind aan de hand is. Zijn voorstel is dan ook af te wachten tot men wat meer weet. Hij verwijst naar bloeduitslagen die onderweg zijn en nog binnen moeten komen. Ook verwijst hij naar onderzoeken die nog zouden moeten gebeuren en waarvoor de aanvragen al de deur uit zijn.

Tijdens de visite camoufleren arts-assistenten hun onzekerheid soms door te spreken in termen van 'het lijkt op', 'het zou kunnen dat', 'ongeveer', 'bij benadering', 'doet denken aan', enzovoorts. Ook geven ze wel expliciet aan dat ze niet zeker zijn van de diagnose of therapie die ze voorstellen. Hun presentatie wordt dan gevoerd in termen als: 'voor zover als ik het nu kan overzien denk ik..', 'Ik denk dat...', 'als we er van uitgaan dat X, dan moeten we misschien ....'. De arts-assistent verwijst naar de toekomst: daar is meer informatie, meer zekerheid en daar ligt dus ook de beslissing. In plaats van te zeggen dat hij niet zo goed weet wat er aan de hand is of wat er gedaan moet worden, wijst hij naar de bloedresten die onderweg zijn. Dit betekent niet dat hij een slechte arts is. Een beslissing moet immers gebaseerd worden op voldoende informatic en hij volgt dan ook louter de mores van het vak.

In sommige gevallen kiest de staf ervoor om helemaal niets te doen in de hoop dat de situatie zich vanzelf ten goede keert en dat het probleem na verloop van tijd vanzelf verdwijnt. In sommige gevallen gebeurt dit ook en tijd is dan een bondgenoot. Deze temporisering van twijfel is echter niet zonder risico's, want het probleem - wat het ook mag zijn - kan ondertussen evengoed uitgroeien tot een nog moeilijker te behandelen aandoening. Tijd is dus een volstrekt onbetrouwbare bondgenoot.

De factor tijd wordt gemaakt en ingezet. De beschikking over tijd is echter niet allesbepalend. In een enkel geval zal de staf er nooit achterkomen wat er precies met het kind aan de hand is. Hoe frustrerend dit kan zijn vertelt één van de nurse-practitioners in het Northeastern:

'Mijn ergste geval was een baby die hier maanden heeft gelegen zonder dat ik wist wat het was. Al die maanden heb je geen basis van waaruit je kunt werken. Het is voortdurend iets proberen en kijken of het werkt. Ik heb ook al die maanden niet aan de ouders kunnen duidelijk maken wat er aan de hand was. Je hebt geen naam die je naar voren kunt schuiven. We konden er ook niet achter komen of het erfelijk was. Het kind ging na een half jaar naar huis en een jaar daarna kregen de ouders nog een kindje. Hetzelfde verhaal. Het was dus wel erfelijk.' 
Het kunnen definiëren van de aandoening is belangrijk, ook als het een aandoening betreft waarvoor geen behandeling bestaat, zoals trisomie $13^{*}$ en $18^{*}$. Met deze diagnoses weet de betrokken arts in ieder geval dat zijn onmacht buiten zijn persoonlijke verantwoordelijkheid valt. Dergelijke situaties zijn echter uitzonderingen. In de meeste situaties zijn er wel degelijk diverse concrete handelingsopties. De kwetsbare conditie van de kinderen op de NICU maakt dat hun handelingstraject nauwkeurig moet worden uitgestippeld. Hierbij maken artsen gebruik van richtlijnen.

\section{Het gebruik van richtlijnen}

De behandeling van de kinderen op de NICU is gebaseerd op bestaande routes die succesvol zijn gebleken: behandelingsprotocollen. Een protocol is een verzameling richtlijnen dat artsen en verpleegkundigen precies vertelt wat zij in een bepaalde situatie moeten doen." Voor het uitzetten van een handelingstraject kan de staf gebruik maken van deze routebeschrijvingen die hen stapsgewijs door medische situaties heen loodsen. Het protocol schrijft voor welke diagnostische testen er moeten worden uitgevoerd, welke behandelingscriteria gelden, welke richting de behandeling moet nemen na een bepaalde uitkomst, wanneer er om een informed consent gevraagd moet worden of welke laboratoriumtesten van cruciaal belang zijn en welke niet meer ter zake doen. In termen van 'als ... dan' leidt het protocol artsen en verpleegkundigen stapsgewijs over het handelingstraject. Op deze wijze biedt een protocol structuur in complexe handelingssituaties." De staf heeft zogezegd een deel van haar coördinerende taak aan het protocol uit handen gegeven. Niet alleen een teamhoofd, maar ook een protocol stemt activiteiten op elkaar af, geeft aan welke aspecten van de handelingspraktijk relevant zijn en wie of wat welke rol in de behandeling speelt.

Protocollen zetten de route op het handelingstraject uit die de behandeling de meeste kans van slagen geeft. Het protocol zet een ideaal behandelingstraject uit: een rechte progressieve lijn. ${ }^{7}$ Daar is echter wel een ideale patiënt voor nodig: een kind dat snel en probleemloos op de behandeling reageert. Daarvan zijn er niet veel op de NICU, want juist die worden doorgaans al snel naar de high care overgeplaatst. De NICU is er voor kinderen met een grillig en complex ziekteverloop. Hun ontwikkeling wordt eerder gekenmerkt door ups and downs dan door een gestaag opgaande lijn. Het gebruik van richtlijnen, die een lineaire ontwikkeling veronderstellen, en de grilligheid van het ontwikkelingspatroon van kinderen op de NICU lijken niet bij elkaar aan te sluiten. Dit kan artsen in de positie brengen dat ze een keuze moeten maken tussen het handhaven van het protocol en de eigenheid van her kind veronachtzamen, of het protocol verlaten en het eigen tempo van het kind vooropstellen. Deze inflexibiliteit is aanleiding tot kritiek op handelingsprotocollen als instrument in de besluitvor- 
ming." Protocollen zouden door hun rigiditeit voorbijgaan aan de complexiteit van de medisch praktijk. Klinische beslissingen worden als een zuiver rationele activiteit voorgesteld: ze staan los van hun sociaalmateriële context. Er bestaat bovendien niet voor elke aandoening een officiële richtlijn. Het probleem dient zich dus aan dat niet de instabiliteit van het kind, maar de behandeling zelf een bron van onzekerheid is.

Voor de behandeling van Roberts hartafwijking heeft de NICU in het Academisch Centrum geen protocol in de la liggen. Daarom schrijft de kindercardioloog zelf een handelingsrichtlijn, die geheel op de situatie van Robert is toegesneden." Op basis van Roberts diagnose - 'transpositie' - ontvouwt zich zo een beeld van het traject: de operatie, de medicatic, de voorzorg en de nazorg, het tijdspad én de mogelijke complicaties. De richtlijn die speciaal door de kindercardioloog is geformuleerd, fungeert als leidraad, maar de staf is zich bewust van de vele valkuilen, van het feit dat aan elke fase en aan elk overgangsmoment risico's zijn verbonden.

\section{Academisch Centrum}

Maandag 14,00 uur: Er is een klinische les voor de verplecgkundigen over de transpositie van morgen. De bijeenkomst wordt druk bezocht. Met behulp van dia's legt de kindercardioloog het probleem uit en vertelt wat er morgen tijdens de operatie zal gebeuren. Vervolgens gaat hij in op alles wat er gedaan moet worden en waar op gelet moet worden, zowel voordat het kind naar de O.K. gaat als na zijn terugkeet op de NICU.

De cardioloog benadrukt dat een 'hartekind' als dit om een andere houding vraagt: 'Normaal hebben we te maken met onvoldoende longfunctie. Dan heb je nog enigszins de tijd om te raadplegen wat je doet. Je draait eens aan de zuurstofknop en zo. Op zich kan alles dan in overleg gedaan worden. Een kind met dit soort hartproblemen vraagt direct ingrijpen. Er is geen tijd om te overleggen in een kamertje. Het is daarom van belang dat jullie van tevoren het protocol dat ik heb geschreven goed doornemen. Het protocol is heel belangrijk maar het is de actuele situatie die te allen tijden blijft bepalen wat er gedaan moet worden.'

Dinsdag 10.00 uur: Robert is vanmorgen om acht uur naar de O.K. gegaan. Op de afdeling heerst een gespannen sfeer. Vaak klinkt de vraag of iemand weet hoe het gaat met de operatie en hoe lang het nog duurt voordat hij terugkomt op de afdeling. De attending raakt wat geïrriteerd door al deze aandacht; 'Al die poespas om dat ene kind. De andere kinderen zijn ook belangrijk.'

Vooral het moment dat Robert van de hart-longmachine wordt afgekoppeld is zeer riskant. Als Robert deze functies niet zelf kan overnemen, sterft hij. De kindercardioloog is zich hier zeer bewust van: 
'Dit soort kinderen vergt heel veel stress. Als alles goed gaat kan ik morgen de hele wereld aan. Dan ben ik helemaal high. Gaat het bij zo'n kind mis dan ben ik de komende dagen geen mens meer. Dan ben ik dodelijk vermoeid en kan ik niets meer aan. Het vergt zoveel van je. Je geeft je helemaal bij zo'n kind.' Er zijn altijd een paar spannende momenten waarop je bang bent dat het mis gaat. 'Zo'n moment is als je het kind van de hart-longmachine afhaalt en het die functies weer zelf moet gaan overnemen. Lukt dat niet dan zit je vast. ${ }^{20}$ Daarnaast moet je het bloed weer op de normale stollingswaarde krijgen. Het bloed wordt tijdens de operatie sterk verdund om embolieën* te voorkomen. Dit terugbrengen van de stollingsfactor op de normaalwaarde is ook heel belangrijk. En het kind moet goed droog gemaakt worden. "Ton (de hartchirurg JM) was al lang klaar met de eigenlijke operatic, maar hij is nog een paar uur bezig is geweest om her bloed weer op zijn juiste stollingsniveau te krijgen en de wond droog te maken. We hebben geprobeerd om de thorax te sluiten omdat het de kans op infecties vermindert. Maar de saturatiewaarde* daalden direct. Daarom hebben we het alleen met een patch afgesloten. De bloedwaarden blijven nu mooier omdat er minder druk op de vaten staat. Bovendien kunnen we er zo makkelijk bij als het mis gaat.

In dit geval verloopt alles rustig en Robert wordt teruggebracht naar de NICU. Al is de hartoperatie dan geslaagd, van een 'hoerastemming' is nog geen sprake. De eerste achtenveertig uur na de operatic blijft het risico dat Robert overlijdt zeer groot. Met de succesvolle afkoppeling van de hart-longmachine is een belangrijke hobbel op het traject genomen. Het volgende risico dient zich echter direct aan bij Roberts terugkeer op de afdeling.

\section{Academisch Centrum}

Dinsdag 17.00 uur: Robert komt terug op de afdeling. Hij wordt vergezeld door "een groene stoet" cardiologen, anesthesisten, neonatologen en verpleegkundigen. Zoals hij daar gewikkeld ligt in lijnen en draden valt er geen baby meer in te herkennen. Nu komt een moeilijk moment: het overbrengen van Robert van de reanimatickar naar zijn couveuse. Er is veel over dit moment gesproken en het is in de voorbereiding keer op keer doorgenomen. Zoals voorspeld is het een 'spaghetti' van draden en slangen die nauwelijks uit elkaar te houden zijn. Het is goed opletten en lezen wat er staat. Maar het moet wel snel gebeuren, want het kind kan niets verdragen. Hoe eerder het rustig in de couveuse ligt, hoe beter. Voorzichtig wordt hij tegelijk met zijn technologische bagage opgetild en in zijn couveuse gelegd. Iedereen kijkt gespannen naar de monitor waar de waarden direct omhoog en omlaag schieten. Maar al snel trekken ze weer bij. Het is gelukt en de staf haalt opgelucht adem. 
Risico's onderscheiden zich door hun graad van waarschijnlijkheid: het is onzeker of problemen zich daadwerkelijk zullen voordoen. Een manier waarop de staf met deze onzekerheid omgaat is door het waarschijnlijkheidskarakter van risico's te negeren en ze als gegeven gebeurtenissen te beschouwen. Men handelt op basis van onzekerheid, totdat het tegendeel blijkt. Onzekerheid wordt gezien als een onvermijdelijk bestanddeel van de dagelijkse praktijk." Het bestaan van onvoorziene en ondoorzichtige situaties wordt verdisconteerd in de inrichting van het handelingstraject. In de richtlijnen voor Roberts behandeling wordt bij voorbaat uitgegaan van de problemen die zich kunnen voordoen. Het feit dat er een kans bestaat dat Robert na de operatie een bloeding kan krijgen, wordt niet vertaald in een keuze op basis van de kans dat er een bloeding optreedt, afgezet tegen de kans dat deze zich niet voordoet. De bloeding wordt niet als mogelijkheid maar als zekerheid beschouwd. Dit vloeit voort uit de keuze tussen het ene risico (een bloeding waar men niet snel bij kan) en een ander risico (een infectie). In het geval van Robert besluit men het eerste uit te sluiten, een beslissing die al enkele uren na de operatie wordt gerechtvaardigd:

\section{Academisch Centrum}

Dinsdag 19.30 uur: De borstkas van Robert is afgedekt met een grote plastic pleister. Sinds een half uur bolt de pleister iets op. Al zijn parameters zijn goed behalve zijn veneuze saturatiewaarde ${ }^{*}$. Er wordt besloten niet te wachten tot de overige parameters ook zakken. De veneuze saturatie zegt genoeg; het kind heeft een bloeding. Er moet nu direct worden ingegrepen. Er is geen tijd meer om hem eerst naar de O.K. te brengen. Dat is te riskant en niet nodig. Terwijl de chirurg zich in zijn steriele kleding hijst, treffen twee verpleegkundigen de nodige voorbereidingen. Op een karretje wordt een steriel veld gemaakt. In de la onderop worden alle benodigde spullen gelegd. Iemand haalt een zuiger van de O.K. op. Ook de anesthesist maakt zich gereed.

De plastic pleister wordt opengesneden en het oude bloed dat zich heeft opgehoopt wordt weggezogen. De grotere stolsels worden er met een pincet uitgehaald en gewogen. Waarschijnlijk hebben deze bloedstolsels de drain verstopt zodat het wondvocht niet meer weg kon. Dit heeft tot een drukverhoging rond het hart geleid, waardoor de pompfunctie van het hart omlaag is gegaan. Met het wegzuigen neemt de druk af en de parameters op de monitor trekken langzaam bij. Op het eerste gezicht lijkt het mee te vallen, maar al snel komt er vers rood bloed te voorschijn. De druk heeft dus wel degelijk tot een bloeding geleid. De chirurg zet zijn operatiebril en hoofdlamp op en gaat op zoek naar het lek. Ondertussen krijgt Robert een bloedtransfusie. Al snel wordt het lek gevonden en het gat gedicht. De bloeding stopt. De chirurg staat te vloeken van opluchting. Hij is steeds rustig gebleven, maar nu het gevaar geweken is, komt de spanning eruit. Het is hem gelukt de bloeding op tijd te stoppen. Iedereen reageert opgelucht. Op de monitor is duidelijk zichtbaar hoe Robert uit de crisis klimt. 
Door de bloeding als mogelijke gebeurtenis in het protocol voor Robert op te nemen, is de staf voorbereid. Op het moment dat de bloeding zich daadwerkelijk voordoet, kan er direct gehandeld worden: de toegang tot het hart is immers nog vrij. Het is slechts een kwestie van 'een grote pleister' eraf halen. Het openhouden van deze noodingang blijkt uiteindelijk van levensbelang.

Behandelen is niet alleen een kwestie van richtlijnen volgen. Richtlijnen bieden steun en wijzen de weg, maar geven geen enkele garantie dat de behandeling van het kind ook daadwerkelijk de uitgezette koers zal volgen. Soms vereist een behandeling juist dat er van de richtlijn wordt afgeweken, of zelfs dat er niets wordt gedaan. Een behandeling bestaat uit meer dan alleen direct ingrijpen of besluiten nemen die onder grote tijdsdruk tot stand komen. Soms is het beter een kind door te sturen naar een gespecialiseerde afdeling in een ander ziekenhuis. Behandelen blijkt evenmin per definitie een gevecht tegen de klok. Op de NICU wordt ook tijd gebruikt en gemaakt om een behandeling voor te bereiden of om deze te laten aanslaan. Dan is geduld het devies.

\section{De rol van techniek op het handelingstraject}

De onzekerheid ten aanzien van het handelingstraject schuilt niet alleen in diagnostische twijfel of aan de behandeling verbonden risico's, maar fungeert ook als cen voortdurende dreiging: een kind stort plotseling in, de hartactie duikt zonder concrete aanleiding naar beneden, of tijdens een routinehandeling, zoals het afplakken van de voedingssonde op de neus, schiet een kind in een bradycardie*. In de meeste gevallen moet de staf dan onmiddellijk corrigerend optreden. Om snel te kunnen ingrijpen is permanent een waakzame houding geboden en techniek is hierbij een belangrijk hulpmiddel. Maar ook de technologie kan niet altijd een onproblematisch traject garanderen.

\section{Techniek en zorg}

Er zijn talloze redenen waarom de zorgverlening op de NICU een bijzonder karakter draagt en één daarvan is dat pasgeborenen niet voor zichzelf kunnen spreken. Neonaten kunnen de arts niet vertellen dat ze hoofdpijn hebben of zich misselijk voelen. Hun situatie is dus extra gebaat bij zorgvuldige observatie en metingen. Via uitslagen van bloedtesten, röntgenfoto's en echo's, het dagelijks onderzoek en de gegevens op daglijst en monitor wordt het kind gevolgd en, waar nodig, zijn behandeling aangepast. Het bewaken en registreren van de toestand van een kind valt grotendeels onder de verantwoordelijkheid van verpleegkundigen." In deze taak worden zij in belangrijke mate bijgestaan door apparaten die de verschillende functies van het kind meten. Met behulp van 
elektrodes op de huid worden allerlei lichaamsfuncties geregistreerd. Wanneer de parameters buiten een ingestelde marge vallen, klinkt het alarm.

De behandeling van kinderen als Tom, Esther en Robert is ondenkbaar zonder de apparatuur die hen omringd. De monitor boven hun couveuse toont de hartfrequentie, polsslag, ademhalingsfrequentic, saturatiewaarde en bloeddruk. Op de vraag: 'hoe gaat het met dit kind?' volgt meestal een blik op de monitor. In één oogopslag weet de staf dan hoe de toestand is. Het apparaat staat tussen de staf en het kind in. Niet als obstakel, maar als bemiddelaar. ${ }^{2} \mathrm{De}$ staf kijkt door middel van de monitor naar het kind. De staf kijkt naar de monitor, maar ziet het kind; zij lijken één geheel. Ook de terminologie waarin er over het kind gesproken wordt, is doorspekt met verwijzingen naar de apparatuur en hun output. De wijze waarop de conditic van het kind wordt gedefinieerd kan niet los gezien worden van de technick waar het mee verbonden is."

Een verpleegkundige in het Academisch Centrum controleert en registreert om de drie uur de toestand van Tom.

\section{Academisch Centrum}

10.00 uur: De verpleegkundige pakt de daglijst die bovenop de couveuse van Tom ligt en schrijft verschillende waarden van de monitor bij de vorige reeks die zij drie uur geleden heeft verzameld. Ze bepaalt met behulp van een kleine stethoscoop de hartslag en telt zijn ademhaling. Ze beoordeelt zijn kleur en schrijft deze bij de rest van de gegevens op de daglijst. De infuussystemen worden gecontroleerd. In de één zit voeding en in de twee andere medicatic. De snelheid en hoeveelheid van elk infuus wordt geregeld door de perfusor". De standen worden op de daglijst genoteerd. Van het beademingsapparaat worden druk en percentages afgelezen en bijgeschreven. Ze neemt bloed af voor onderzoek. Over drie uur zal de verpleegkundige opnieuw alles meten, controleren en noteren.

Afhankelijk van de instabiliteit van de conditie van een kind wordt de frequentie van de controles verhoogd. ${ }^{26}$ De extreme instabiliteit van bijvoorbeeld de conditie van Robert vereist een zeer intensieve bewaking.

Robert is vlak na zijn operatie zo instabiel dat de verpleegkundigen zijn toestand elk uur moeten controleren. Zijn daglijst heeft zoveel parameters dat de ene controle in de andere overloopt. De verpleegkundigen die betrokken zijn bij zijn zorg hebben nauwelijks een moment rust. Wat de situatie verder compliceert, is het feit dat hij niet alleen een neonaat is, maar ook een cardiologiepatiënt. Voor zulke patiënten gelden andere regels en worden andere daglijsten gebruikt. De indeling van een daglijst voor hartpatiënten wordt zelden op de afdeling neonatologie gebruikt en dit maakt de bewaking van Robert tot een dubbel zware opgave. Niet alleen de hoeveelheid parameters maakt zijn controles ingewikkeld, maar ook de registratie van deze getallen. Het blijft iedere keer weer zoeken op de daglijst en opletten of alles op de juiste regel wordt geschreven. 
Op de NICU van het Academisch Centrum zijn nog nauwelijks kinderen met een transpositie opgenomen. Hierdoor hebben de verpleegkundigen geen gelegenheid gehad om voldoende ervaring en routine op te bouwen. De complexiteit van de bewaking van Robert blijkt gespecialiseerde kennis en ervaringte vereisen, die op de afdeling nog nauwelijks voorhanden zijn.

\section{Academisch Centrum}

Woensdag 15.00: De avonddienst komt binnen. Er ontstaat lichte paniek. Van de gediplomeerde verpleegkundige acht niemand zichzelf ervaren genoeg om de verantwoordelijkheid voor de zorg van Robert over te nemen. Een van hen: 'Het zijn steeds dezelfde mensen die dit soort kinderen doen, waardoor anderen, waaronder ik zelf, er geen ervaring in krijgen. En dan kun je nu niet van ons verwachten dat we dit eventjes doen. Moet je zien wat er allemaal bij dat kind aanhangt. Dat doe ik niet.' Er wordt gewisseld met een verpleegkundige die voor vanavond op de HC staat ingedeeld.

20.30: Alles is rustig op de afdeling. De attending schrijft aan tafel zijn verslag in de status. De verpleegkundige vult de daglijst in van Robert. Ze heeft er een hoge kruk bij gepakt en een katheder waar de lijst op kan liggen. Tot ieders opluchting blijven de andere kinderen rustig vanavond. De staf kan er nu geen noodsituatie bij hebben. Vanaf de aangrenzende high care klinkt een speeldoos. Een verrassend speels geluid in deze klinische setting.

Hoewel de expertise voor Roberts behandeling wel binnen de afdeling beschikbaar is, blijkt het niet altijd eenvoudig om die goed te verdelen over de aanwezige staf. Disciplinaire verschillen en dienstroosters leiden ertoe dat intensieve bewaking naast middel ter bestrijding van twijfel en toeval ook een bron van onzekerheid wordt. De beste stafleden voor bepaalde gevallen kunnen niet vierentwintig uur per dag aanwezig zijn en niet iedereen heeft evenveel ervaring. Wat is bijvoorbeeld de juiste interpretatie van de waarde op de monitor? Is Robert een cardiologiepatiënt of een neonatologiepatiënt? Waar zet je de getallen op een daglijst die je nooit eerder hebt gezien? Hoe kom je als arts-assistent de avonddienst door met een kind als Robert onder je hoede? Blijft de attending ook vanavond nog in de buurt?

\section{Academisch Centrum}

Maandag: Het gaat goed met Robert. Hij knapt zienderogen op. Ook zijn technologische bepakking is aanzienlijk geslonken. Van de acht slangen die hem vorige week voorzagen van de nodige medicatie, extra bloed, zuurstof en voeding en die zijn wondvocht en urine afvoeren, zijn er nog maar drie over.

Het traject van Robert wordt sterk gedomineerd door technologie. De staf kijkt voortdurend naar de monitor, schrijft over de getallen op de apparatuur, brengt slangen in, plakt ze af en haalt ze er weer uit. De vraag rijst of er nog wel 
aandacht voor het kind zelf overblijft, of dat de staf alleen nog maat oog heeft voor de input en output van de apparatuur?

Deze vraag gaat uit van een tegenstelling tussen techniek en zorg, waarbij aandacht voor technick ten koste zou gaan van de zorg. De gedachte dat technologie en zorg op gespannen voet met elkaar staan, is echter gebaseerd op een definitie van techniek die haar sociale dimensie negeert en een definitie van zorg die voorbij gaat aan de materiële en technologische aspecten hiervan. "Worden deze verschillende dimensies wel aan elkaar gerelateerd, dan verdwijnt het oppositionele karakter van de relatie tussen technick en zorg. Technick staat zorg dan niet in de weg, maar draagt juist bij tot een verbetering van zorg. "Op de NICU zorgt men voor de kinderen met bebulp van techniek, zoals het waarschuwingsalarm van de monitor of de elektrische tandenborstel waarmee verpleegkundigen het slijm in de longen van een kind loskloppen. De verbondenheid van kind en techniek impliceert dat bezigheden die verbonden zijn aan de apparatuur ook zorg voor het kind betekenen. De verzorging van Robert in de eerste uren na zijn operatie is bijvoorbeeld geheel in handen van de techniek: alleen de lijnen en draden van de vele apparaten raken hem aan. Dit betekent niet dat de staf geen omkijken naar hem heeft. Integendeel. Robert eist alle aandacht op, maar de meeste handelingen spelen zich buiten de couveuse af. Zijn verzorging betekent het controleren van apparatuur, het vergelijken van uitslagen, het noteren van waarden en het bijstellen van de instellingen. Technologie vormt hier geen obstakel, maar biedt als het ware een materiele passage naar een kind dat zich tijdelijk buiten het bereik van mensenhanden bevindt. Op de

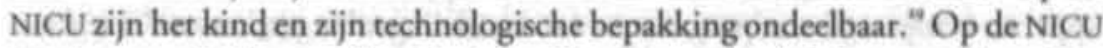
betekent aandacht voor de techniek ook zorg voor het kind en omgekeerd.

\section{Disciplinering van de handelingspraktijk}

Met de medisch-technologische apparatuur heeft de staf een belangrijk hulpmiddel in handen om de kinderen op de NICU te verzorgen en te behandelen. Maar is techniek louter een hulpmiddel? Gezien de prominente aanwezigheid ervan op het handelingstraject van kinderen zoals Robert, Tom, Esther en Maureen is het zinvol om de rol van apparaten in relatie tot hun gebruikers nader te analyseren. Welke functie vervult bijvoorbeeld het beademingsapparaat in de manier waarop het handelingstraject vorm krijgt?"

Een kind aan de beademing betekent in de praktijk een voortdurend zoeken naar de juiste balans. Dit vraagt een nauwkeurige registratie en een voortdurend corrigeren van de richting waarin het kind zich ontwikkelt. Ter bepaling van de optimale instelling van het beademingsapparaat wordt de saturatie van de zuurstof vastgesteld. Dit kan door middel van een infrarood lampje dat op de hand wordt geplakt. De monitor boven de couveuse geeft de gemeten 
saturatiewaarde in percentages aan. Het saturatiegehalte kan ook bepaald worden door via een lijn in een van de (slag)aders bloed af te nemen, dat vervolgens in het laboratorium wordt onderzocht. Anti-stollingsmiddelen moeten voorkomen dat deze lijn verstopt raakt. Aan de hand van de saturatie bepaalt de arts de instelling van het beademingsapparaat. Het ademhalingsritme van een kind loopt echter niet synchroon met dat van het beademingsapparaat. Medicatie dient daarom de spontane ademhaling van het kind te onderdrukken, zodat het niet kan gaan tegenademen. Daarnaast krijgt een prematuur kind ook surfactant* om de ventilatiefunctie van de onrijpe longen te bevorderen. Met behulp van röntgenfoto's en regelmatige bloedtesten houdt de staf zich op de hoogte van de ontwikkeling van de longen. Met de ene beslissing (een kind aan de beademing koppelen) haalt de staf dus tevens een reeks toekomstige - op dat moment nog niet nader omschreven - beslissingen binnen (het toedienen van spierverslappers).

Het beademingsapparaat speelt een belangrijke rol in de behandeling van de kinderen op de NICU en de prematuren in het bijzonder. Een correct gebruik van het apparaat is dan ook van groot belang. Zoals elk apparaat heeft ook het beademingsapparaat een handleiding dat de gebruiker vertelt hoe het bedient moet worden. Het gebruik van een beademingsapparaat vraagt echter meer dan het inbrengen van de tube in de luchtpijp en het instellen van het apparaat. Het vereist een bepaalde organisatic van de praktijk en een aanwezigheid van bepaalde kennis en ervaring. Deze aspecten staan niet in een handleiding, maar worden wel aanwezig verondersteld wil het apparaat kunnen werken. In het apparaat is zogezegd cen 'programma van handelingen' ingeschreven." Deze impliciete handleiding noem ik het script van het apparaat. "Dit script definieert niet het directe gebruik van een beademingsapparaat zoals de handleiding dit doet, maar het definieert rollen en taken van de artsen, verpleegkundigen en middelen die in de praktijk bij de behandeling betrokken worden." Niet alleen apparaten dragen een script. Ook de status met patiëntengegevens draagt een script dat de arts voorschrijft welke aspecten van het kind moeten worden

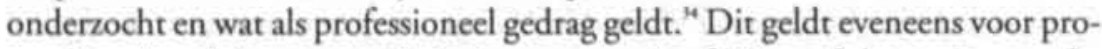
tocollen, het sluissysteem bij de ingang van de afdeling of de monitoren die boven de couveuses hangen. Allen dragen zij een programma van handelingen in zich dat de NICU-praktijk zodanig disciplineert dat hun gebruik ook daadwerkelijk mogelijk wordt." Met het script als tweede orde begrip kan ik onderzoeken op welke wijze het gebruik van medische apparatuur, zoals een beademingsapparaat, de NICU-praktijk structureert.

Met de koppeling van Tom aan een beademingsapparaat conformeert de staf zich aan een bepaalde ordening van activiteiten die het gebruik van het apparaat voorschrijft. Met de inzet van het beademingsapparaat wordt een veelvoud aan bijkomende handelingen aan het handelingstraject toegevoegd. Een nauwkeu- 
rige instelling van het beademingsapparaat vergt bijvoorbeeld geregeld bloedonderzoek. Tom moet daarom dagelijks worden geprikt. Om het overzicht te bewaren worden tijdens elke controleronde van de verpleegkundige zowel de instellingswaarden van het apparaat als de getallen op de monitor genoteerd. De beademingsslang mag er niet uitschieten. Om te voorkomen dat Tom deze er toch uit zou werken, wordt deze gefixeerd op zijn bovenlip. Een paar keer per week moet de slang opnieuw worden afgeplakt. De tube van de beademingsslang leidt bij Tom tot irritatie van zijn keel. Daarom moeten verpleegkundigen meerdere malen per dag zijn keel uitzuigen. Voor een optimale beademing moet Tom rustig met het ritme van het apparaat meeademen. Om tegenademen te voorkomen krijgt hij spierverslappers. Kortom, tegelijk met het apparaat wordt een reeks aan activiteiten het handelingstraject binnengehaald.

Om het apparaat naar behoren te laten functioneren moet het script systematisch worden gevolgd. Er gaat zogezegd een disciplinerende werking van apparaten uit: het alarm van de monitor boven de couveuse doet een verpleegkundige opspringen en tot actie overgaan. Een infuus voorziet het kind de hele dag van voeding, maar na precies vierentwintig uur moet een verpleegkundige dit infuus vervangen; als dit wordt uitgesteld, dan hangt er een leeg infuus aan en dat is riskant. Om dit te voorkomen waarschuwt een perfusor" de verpleegkundige met luid alarm vlak voordat het infuus leeg is. Wordt het voedingsinfuus echter te vroeg verwisseld, dan krijgt het kind niet zijn volledige hoeveelheid voeding binnen. De verpleegkundige die voor het kind zorgt heeft geen keus: als de perfusor 'roept' moet zij het infuus verwisselen.

Apparaten zorgen voor het kind, mits er aan bepaalde condities is voldaan. De monitor waakt over een kind, mits de elektrodes op de juiste plek zijn aangebracht, de draden naar de monitor vrij liggen en de grenzen voor het alarm zijn ingesteld. De couveuse zal de luchtvochtigheid op peil houden, mits het voldoende water heeft. Een infuussysteem zal het kind voeden, mits het infuus goed is aangesloten. Hierbij dienen we ook de kinderen op de afdeling als gebruikers van techniek te beschouwen. Net als de andere gebruikers van de medische apparatuur moeten ook zij het ingeschreven script volgen. Het infuus zal het kind voeden, mits het stil genoeg ligt. Een te wilde beweging en het infuus kan uit het bloedvat schieten. Het beademingsapparaat zal het kind beademen, tenzij het kind de tube eruit werkt of het tegenademt. Via het ingebouwde script leggen apparaten hun normen aan de praktijk op. ${ }^{16}$ De precisie van apparaten dwingt zo bepaald gedrag af. Handelingen, zoals het dagelijks prikken, sederen en fixeren van een kind, behoren hierdoor op deze afdeling tot de routine. Op deze wijze laat het gebruik van apparaten bepaalde praktijken 'stollen' tot iets 'normaals'."

Techniek speelt ook een rol in de structurering van de sociale orde op de afdeling." Het gebruik van apparaten veronderstelt een bepaalde competentie 
en verdeelt op deze wijze taken en de bijbehorende risico's over verschillende personen. Het geeft aan wie bevoegd is tot gebruik van het apparaat en wie er (nog) niet aan mag komen. Met het gebruik van apparaten ontstaat een onderscheid tussen meer en minder competente stafleden; wie vaardig genoeg is om in tijden van nood snel een kind te kunnen intuberen" en wie de durf heeft om voor een kind als Robert te zorgen. Op deze wijze speelt het script een rol in de wijze waarop de sociale orde vorm krijgt. Deze orde kan dwars door formele hiërarchische of disciplinaire lijnen heenlopen. In het Northeastern General Hospital heeft bijvoorbeeld één van de neonatologen de grootste moeite om een infuus te zetten bij een kind dat moeilijk is aan te prikken. Om het kind niet langer van streek te maken, vraagt hij een arts-assistent die bekend staat om zijn buitengewone vaardigheid met 'moeilijke' vaten om het van hem over te nemen. Deze zet het infuus er inderdaad in een keer in en dwingt hiermee respect af. Ook op andere wijze spelen apparaten een rol in de structurering van de sociale orde. Het behandelteam bepaalt welke apparatuur er wordt ingezet, maar de techniek bepaalt waaruit het behandelteam bestaat. De technick die Roberts operatie mogelijk maakt, brengt andere disciplines op het handelingstraject in: kindercardiologie, chirurgie en anesthesie. Zodra hij met minder slangen toe kan, verdwijnen er ook meer specialisten naar de achtergrond. Technick bindt én ontbindt."

Techniek beperkt haar structurerende werking van de sociale orde niet tot stafleden en ouders, maar strekt zich ook uit over het domein van de kinderen. Techniek biedt hen mogelijkheden en beperkingen, maar niet voor iedereen op gelijke wijze. Aan een prematuur kind dat na drieëntwintig weken zwangerschap wordt geboren, biedt het beademingsapparaat minder kansen en meer risico's dan aan een kind geboren na achtentwintig weken zwangerschap. Techniek maakt zo keer op keer een nieuwe indeling van kinderen met kansen en kinderen zonder kansen. Welk apparaat aan wie mogelijkheden verschaft, staat niet vast. Een kind als Robert had vroeger geen enkele kans op overleving. De huidige techniek maakt zijn overleving mogelijk. Ook kinderen als Esther en Tom hadden nog niet zo lang geleden geen enkele kans op overleving. Het script dat het apparaat in zich draagt, trekt grenzen en doorbreekt grenzen. Grenzen van mogelijkheden én bestaan.

Wie apparaten louter afdoet als een passief hulpmiddel in handen van mensen, negeert de verschillende wijzen waarop techniek actief bijdraagt aan de concrete invulling van het handelingstraject. Nadruk op de actieve inbreng van apparaten resulteert mogelijk in een beeld van de NICU als een domein waarin techniek de dienst uitmaakt - alsof het menselijk handelen geheel en al wordt gedicteerd door de aanwezige technologie en de sociale en morele gevolgen ervan volledig vastliggen. ${ }^{* 0}$ Techniek geeft echter niet alleen vorm aan het handelingstraject, maar het krijgt zelf ook vorm in het traject." Hoe en in welke 
mate er wordt voldaan aan de formele eisen die een apparaat stelt, is afhankelijk van de wijze waarop het apparaat wordt ingezet. Hierbij is techniek slechts éen van de middelen die de staf inzet in de behandeling en zorg van een kind. Het apparaat, inclusief de specifieke kennis en handelingen die het met zich meebrengt, gaat deel uitmaken van de veelheid aan activiteiten. Op het handelingstraject wordt de uitvoering van die activiteiten bepaald door talloze factoren, zoals de toestand van het kind, organisatorische aspecten, tijdsdruk en onderzocksuitslagen. Er vindt een wederzijdse afstemming plaats tussen apparaat en gebruiker. In dit proces krijgt ook het apparaat zelf zijn vorm, functie en betekenis.

\section{Techniek als probleem}

Elk gebruik van de apparatuur geldt in principe als een tijdelijke aangelegenheid. In het begin wordt een behandelingstraject sterk gedomineerd door de anwezigheid van medische technologie, die de vitale functies van een kind ondersteunt of geheel overneemt. Naarmate de tijd verstrijkt, zal het kind beetje bij beetje het beheer over zijn lichamelijke functies moeten hernemen om uiteindelijk geheel onafhankelijk van de technologie te kunnen functioneren. Zonder dit gebruik van techniek zou het leven van Tom en Robert nooit mogelijk zijn geweest.

De inzet van techniek is echter niet geheel zonder risico's. Dit is duidelijk zichtbaar bij de kunstmatige beademing van premature kinderen. De longen van een prematuur geboren kind zijn nog onrijp waardoor het nog niet in staat is om zelf in de zuurstofbehoefte te voorzien. Tot de longen zijn volgroeid neemt een beademingsapparaat deze functie geheel of gedeeltelijk over. Hierbij wordt een bepaalde concentratie zuurstof onder beademingsdruk in de longen gepompt. Wanneer een kind langdurig onder hoge druk wordt beademd, kunnen de tere longblaasjes de druk niet weerstaan en gaan ze kapot. Het beschadigde longweefsel verliest zijn elasticiteit en de opnamecapaciteit van de longen neemt af. Dit verschijnsel, broncho pulmonary dysplasie (BPD) ${ }^{*}$ genaamd, is een ingecalculeerd verschijnsel bij kunstmatige beademing van ernstige prematuren. Met het inzetten van een beademingsapparaat begint voor de staf dan ook het 'koorddansen'. Een kind aan de beademing betekent een voortdurend zoeken naar de juiste balans. De complexiteit van deze doelstelling is zichtbaar in het verloop van de behandeling van Tom.

$\mathrm{Al}$ na enkele weken manifesteren zich bij de Tom de eerste kenmerken van BPD. De staf realiseert zich terdege dat als de beschadiging van zijn longen te groot wordt, hij voor altijd afhankelijk is van kunstmatige beademing. Daarom is het van belang om hem zo snel mogelijk van het apparaat af te krijgen. De artsen proberen de schade te beperken door de activiteit van de machine te verlagen. Echter zonder succes. Slechte bloedgaswaarden en complicaties dwingen 
de artsen opnieuw de druk op te voeren. Hiermee lijkt elke poging om hem van de kunstmatige beademing af te krijgen gedoemd te mislukken. Tom reageert direct met slechte saturaties die zich nauwelijks verbeteren. Met als gevolg dat hij na drie maanden nog steeds op de NICU ligt. Terwijl andere kinderen na enkele weken naar huis mogen, lijkt Tom steeds verder van zijn thuiskomst verwijderd te raken.

Het beademingsapparaat blijkt niet de betrouwbare bondgenoot te zijn, die de staf voor ogen had toen zij Tom na de geboorte ankoppelde. Gedurende de opname transformeert het beademingsapparaat zich van een levensreddend middel tot een levensbedreigend probleem. Simpel afkoppelen is er niet meer bij. De positieve werking is verweven geraakt met de schadelijke invloed. Het apparaat blijkt dubbelzinnig: behalve een constructief effect heeft het een destructief effect op de behandeling. " Een mogelijkheid om een ander traject in te slaan, één waarop geen beademingsapparaat noodzakelijk is, ligt reeds buiten bereik. Door de verregaande BPD mist Tom de longcapaciteit en de kracht om zijn eigen ademhaling te regelen. De techniek heeft het aantal keuzemogelijkheden teruggesnoeid. Dit betekent dat de staf verder moet gaan op de ingeslagen weg - voorzichtig aftastend hoe ver het kan gaan en voortdurend op zoek naar het punt waarop het apparaat het meest effectief en het minst schadelijk is."

De BPD bij Tom is een voorbeeld van een ingecalculeerd risico dat de staf binnen heeft gehaald op het moment dat er wordt besloten om het kind aan de beademing te koppelen. Met de keuze voor het apparaat kiest men voor de bijbehorende risico's. In het geval van Tom wordt het mogelijke risico realiteit en houdt het apparaat het kind in zijn greep. De onlosmakelijke verbondenheid tussen de noodzakelijke zuurstoftoevoer en de schadelijke werking legt de handelingsvrijheid van de staf aan banden. Dezelfde techniek die direct na de geboorte juist handelingsruimte schept, en zo voor het kind de weg naar huis opent, blokkeert enkele weken later elke poging om de behandeling af te bouwen. Door het script dat in een beademingsapparaat is ingeschreven, vindt er een voorstructurering plaats van de handelingsopties. De inzet van apparaten kan op deze wijze handelingsopties blokkeren, situaties problematiseren en koerswijzigingen afdwingen, en geeft zo vorm aan de invulling van het handelingstraject.

De behandeling van Tom wordt daarnaast ook gedwarsboomd door tal van andere factoren. De vroeggeboorte heeft zijn uitwerking op de bloedvaten niet gemist. De tere vaatjes in zijn hoofd kunnen de bloeddruk niet weerstaan en barsten. De hersenbloeding leidt tot neurologische complicaties, waardoor Tom moeite heeft om zijn blik te fixeren. Los van al deze complicaties, heeft hij bovendien verschillende infecties opgelopen. Hier blijft het niet bij. Ook andere problemen dienen zich aan: 


\section{Academisch Centrum}

Donderdag: Tom heeft al enkele dagen problemen met eten. De onderzoeksuitslagen die vanmorgen zijn binnengekomen wijzen uit dat hij een maagzweer heeft. Tijdens de visite bespreken de artsen de siruatie. Het vermoeden bestaat dat het door de corticosteroïden komt.

Maandag: Tom lijkt verslaafd te zijn geraakt aan valium. Bij elke poging om de valium af te bouwen, reageert hij direct met slechte bloeduitslagen. Alsof hij niet meer zonder kan.

Dinsdag: Tom heeft al dagen hoestbuien. De tube in zijn keel irriteert zo erg dat er een slijmophoping ontstaat. Huilend met horten en stoten probeert hij het slijm weg te hoesten. Door al dit hoesten en huilen krijgt hij het weer benauwd, wat hem nog harder doet huilen. De verpleegkundigen die voor hem zorgen trachten hem uit deze vicieuze cirkel te halen door geregeld zijn keel uit te zuigen. Maar ook deze handeling is voor hem een kwelling zodat hij alsnog moet huilen en het weer benauwd krijgt. De verpleegkundigen raken moedeloos. 's Middags komen Toms moeder en oma op bezoek. Zij weten ook niet hoe ze Tom rustig kunnen krijgen. Wat ze ook proberen, niets helpt. Hij blifft huilen. Geluidloos. Omdat de tube in zijn keel het hem onmogelijk maakt om geluid te maken. Uiteindelijk kan zijn oma her niet langer aanzien. In de oudersluis wacht ze huilend op haar dochter.

Terwijl Toms moeder bij de couveuse staat, komt een verpleegkundige haar vragen of ze nog even kan blijven omdat de arts met haar wil praten. De moeder schrikt zichtbaar. 'Wat zou er nu weer aan de hand zijn? Als artsen met je willen praten is het nooit zomaar.' Haar angstig voorgevoel blijkt terecht. De artsassistent vertelt haar dat Tom waarschijnlijk stuipjes heeft. Ook blijkt dat de drain in zijn hoofd een beetje te lekken. Het is niet verontrustend, voegt de arts-assistent toe, maar het moet wel in de gaten worden gehouden.

De behandeling van Tom toont hoe neveneffecten van interventies uit kunnen groeien tot een omvangrijk probleem. Naarmate de problemen zich opstapelen wordt het steeds moeilijker om het kind op het juiste spoor te houden en moet de staf keer op keer terug naar de kaartentafel om een nieuwe koers uit te stippelen.

Wanneer er complicaties optreden, worden er nieuwe behandelingsprotocollen aan het traject toegevoegd. Hiermee vindt er een verdichting plaats van het aantal behandelingslijnen dat rond het kind samenkomt. Elke nieuwe interventie moet worden ingepast in een groeiend stelsel van interacties, maar niet alles laat zich inpassen of houdt andere handelingsopties open. Wat te doen met een beademingsdruk of een medicatie die zich niet laten afbouwen? De ene na de andere patstelling kan zich aandienen. Onbedoelde effecten op andere middelen of op lichaamsprocessen kunnen de aanleiding vormen tot nieuwe 
problemen, die om nieuwe interventies vragen. Er ontstaat een 'locomotive phenomenon' waarbij de ene interventie de andere uitlokt. " De bewegingen van de interventies verliezen hun samenhang en het ideale doel - 'herstel en ontslag' moet worden bijgesteld richting 'second best'.

In situaries als deze stuit de staf op de grenzen van de NICU-praktijk en wordt zij eraan herinnerd dat uiteindelijk de baarmoeder voor een kind de beste plaats blijft om de eerste negen maanden door te brengen. De maakbaarheid van de praktijk wordt beperkt door natuurlijke en technologische grenzen. Een beademingsapparaat met hoge beademingsdruk, bijwerkingen van medicatie, bacteriën, menselijk weefsel dat te teer is - al deze factoren kunnen het ingeslagen pad kruisen. Een problematisch geval als Tom vereist een voortdurende aanpassing van de route die gevolgd moet worden om tot het gewenste resultaat te kunnen komen. Zo'n behandeling houdt meer in dan het louter begeleiden van een kind over een bestaand traject. Het handelingstraject ontstaat in het krachtenveld van staf, apparatuur en de reacties van het kind."

\section{Het getal als kompas}

Bij complexe handelingstrajecten wordt het steeds moeilijker om het overzicht te bewaren en het resultaat van interventies te voorspellen. Getallen bieden houvast. De medische technologie op de NICU produceert elke dag een stroom aan kwantitatieve gegevens. Er worden voortdurend apparaten aangesloten en ingesteld. De monitoren laten vierentwintig uur per dag onrustig knipperende getallen zien. Er gaat bloed naar het lab en wat terugkomt zijn waarden met twee cijfers achter de komma. Voeding en medicijnen, berekend in minuten en cc's, vloeien met een zekere snelheid de lichaampjes binnen. Willen de stafleden weten hoe het met een kind gaat, dan lezen ze de getallen in de status en op de daglijst of ze werpen een vlugge blik op de monitor. Ze lezen HB-waardes, saturatiewaarden en hoeveelheden in- en output op de vochtbalans, in plaats van 'bleekheid' of 'vochtverlies'. Ook de overdracht en visite kenmerken zich door de uitwisseling van een grote hoeveelheid aan getallen van allerlei aard: uren, weken, dagen, cc's, frequenties, percentages, druk, afmetingen en beoordelingen. De conditie van het kind wordt in toenemende mate vertaald en gerepresenteerd in getallen.

Op de afdeling worden getallen niet altijd als harde feiten beschouwd. Numerieke data gelden vaak een objectieve representatie van de lichamelijke conditie van het kind, maar ze kunnen ook de inzet van een onderhandelingsproces zijn. Hoe kan dat? ?t $^{\text {I }}$ In deze paragraaf gaat het mij niet om de intrinsieke waarde van getallen, maar om hun gebruik en betekenis in de constructie van kennis." 


\section{Een betrouwbaar instrument}

De vermenigvuldiging en alomtegenwoordigheid van getallen op de NICU reflecteert het vertrouwen in de belofte van de kwantitatieve benadering: eenduidigheid en objectiviteit. Het gebruik van getallen staat voor een mathematics of certainty. "Geen gissingen of subjectieve beoordelingen, maar vaststaande regels leiden de therapeutische interventie. De getallen bieden de arts een kompas waarop hij zijn beleid kan bepalen.

\section{Academisch Centrum}

De arts-assistent bestudeert de labuitslagen die zojuist zijn binnengekomen: glucose $-0.7 \mathrm{mmo} / \mathrm{l}$. En snelle vergelijking met de normaalwaarde leen dat Ronald hypoglycemisch* is. De arts-assistent besluit om hem een eenmalige bolus van $2 \mathrm{ml}$ glucose $20 \%$ te geven. Een half uur later blijkt deze ingreep echter niet voldoende. Hoewel minder ernstig, tonen de labuitslagen nog steeds een hypoglycemie van $0.9 \mathrm{mmol} / \mathrm{l}$. Daarom besluit hij een infuus in te brengen met glucose $15 \%$. Dit is echter niet het enige probleem waar het kind mee kampt. De monitor geeft een dalende bloeddruk aan: 47/33, 45/29, 38/25. De arts-assistent besluit de dosis cardiotonica te verhogen zodat de bloeddruk weer zal stijgen.

Op de NICU zijn het niet de klachten die de arts de weg wijzen, maar vertellen de getallen wat er aan de hand is en wat er gedaan moet worden. Het effect van handelen is vervolgens weer af te lezen aan de nieuwe uitslagen, die de arts vertellen of hij het bij het rechte eind heeft of niet.

Door hun relatieve eenduidigheid en nauwkeurigheid zijn getallen een belangrijke bouwsteen van de praktische orde op de NICU. De vertaalslag van fysiologische processen naar numerieke eenheden maakt een vergelijking met de gewenste situatie - uitgedrukt in normaalwaarden - mogelijk. Door de laboratoriumuitslagen van het kind naast de normaalwaarde van de gemeten variabelen te leggen, wordt duidelijk hoe het er met het kind voor staat. In het gunstigste geval is er geen discrepantie tussen beide waarden. Een vergelijking met eerdere uitslagen geeft de mogelijkheid om veranderingsprocessen zichtbaar te maken. Hierin ligt het antwoord op de vraag of het kind meer of minder stabiel is, of het herstellende is of juist achteruit gaat. De conditie van het kind kan door vergelijking van getallen zeer nauwkeurig in kaart gebracht worden. Door evaluatie van kwantitatieve representaties van de conditie van het kind tracht de staf de aanwezigheid of de toename van pathologische processen (bijtijds) op te sporen en de behandeling hierop aan te passen. Ook voor dit laatste bieden getallen een nauwkeurigheid die soms tot twee cijfers achter de komma reikt. Doordat ook het functioneren van medische apparatuur in numerieke eenheden wordt weergegeven, kunnen artsen met grote precisie hun apparatuur afstellen en de medicatie met minieme hoeveelheden verhogen of verlagen. De 
kwantitatieve beschrijving van zowel het instellingsniveau van de apparatuur als de conditie van een kind biedt de staf een gezamenlijke taal. Dit voorkomt onduidelijkheden en misverstanden. Geen vage omschrijving in termen van "een beetje meer zuurstof erbij" of "het heeft het wat benauwd", maar getallen die voor maar één uitleg vatbaar zijn. In een kwantitatieve taal vertellen zij elkaar hoe het er met het kind voorstaat en in welke mate de behandeling dient te worden aangepast. De eenduidigheid, vergelijkbaarheid en precisie van getallen heeft ertoe geleid dat een kwantitatief beeld van het lichaam als meer betrouwbaar wordt beschouwd dan een kwalitatief beeld.

Ook in andere medische en maatschappelijke domeinen gelden getallen als objectieve gegevens. Dit maakt dat het belang van het zorgvuldig verzamelen en noteren van getallen verder reikt dan de medische praktijk. Vooral in de Verenigde Staten zijn er ook juridische belangen in het spel." De drempel om een arts voor het gerecht te dagen is hier aanzienlijk lager dan in Nederland. Om een rechtszaak te voorkomen ontstaat al snel de neiging om alles in te zetten wat men aan technologisch vernuft voorhanden heeft en zo een grote verzameling van onderzocksuitslagen aan te leggen. Want ook in de rechtszaal fungeren getallen als objectieve data. Een neonatoloog in het Northeastern General Hospital zegt hierover:

Wij lopen minder kans om juridisch vervolgd te worden doordat we alles doen wat mogelijk is. Wij hebben hier alles in huis en dat gebruiken we ook. Zo kunnen ze ons nooit van nalatigheid betichten. Wat we niet doen, bestaat niet. Dus heeft niemand grond om een klacht in te dienen. Mocht er alsnog een aanklacht wegens 'malpractice' volgen dan zullen de cijfers aantonen dat de juiste beslissingen zijn genomen.'

In het besluitvormingsproces heeft de arts niet alleen te handelen in overeenstemming met de standard level of care, maar moet hij ook rekening houden met juridische regels. In de onzekere wereld van de neonatologie vormen getallen de enige basis voor juridische zekerheid. Om op voorhand bewijsmateriaal in handen te hebben, wordt veel bloedonderzoek aangevraagd en elke stap van de arts vastgelegd en genoteerd. Het juridische systeem stuwt zo de productie van getallen en de bijbehorende administratie in de medische praktijk verder omhoog.

\section{De interpretatie van getallen}

Op het eerste gezicht lijkt het medisch handelen op de NICU vooral een kwestie van het verzamelen en vergelijken van getallen. Op basis van kwantitatieve feiten kiest de arts voor een bepaalde behandeling. Wil hij weten of de behandeling succes heeft, dan verzamelt hij nieuwe getallen en vergelijkt ze met de oude. Kwantitatieve gegevens spreken echter zelden voor zich; zij moeten meestal informatief gemaaktworden, wat betekent dat ze weer nieuwe activiteiten genereren. 


\section{Academisch Centrum}

De attending komt binnen en er kan worden begonnen met de dagelijkse visite. De arts-assistent legt hem zijn diagnose voor die hij nu op basis van de extra onderzoeksuitslagen rond heeft. Gezien de wisselende bloeddruk heeft hij het vermoeden dat er zich een hersenbloeding bij Ronald heeft voorgedaan. Hij heeft al een aanvraag voor een echo gedaan.

De attending is echter niet zo snel tevreden als de arts-assistent: 'Natuurlijk is deze conclusie heel goed mogelijk en de echo zal uit moeten wijzen of je gelijk hebt. Maar er leiden meerdere wegen naar Rome, dus mogen we andere potenticle oorzaken voor dit grillige beeld niet uitsluiten.' Er volgt druk overieg in termen van: 'het zou dit kunnen zijn, maar ik sluit niet uit dat.., en heb je daar ook nog aan gedacht.' Verschillende mogelijkheden passeren de revue. Het resultaat van deze discussie is een nieuwe serie bloedtesten en dus een nieuwe reeks getallen.

Getallen vertellen de stafleden dus niet wat te doen. Die beslissing moeten ze zelf nemen. De getallen fungeren bij deze beslissing wel als uitgangspunt. Wat zegt bijvoorbeeld een verhoogde of verlaagde bloedwaarde over de oorzaak ervan? De uitkomsten van onderzoek kunnen op verschillende oorzaken wijzen, die uiteenlopende interventies vereisen. Dit betekent dat getalsmatige gegevens pas waarde krijgen, als ze aan elkaar worden gerelateerd: als X stijgt, behoort $\mathrm{Y}$ omlaag te gaan. Zo niet, dan is er iets anders aan de hand. Diagnosticeren is op deze manier een kwestie van het uitsluiten van mogelijkheden.

Het vermogen tot het juist interpreteren van getallen is steeds afhankelijk van kennis. Bovendien scheppen de getallen lang niet altijd duidelijkheid en kunnen ze zelfs aanleiding zijn tot verwarring":

\section{Academisch Centrum}

De arts-assistent staat naast de couveuse van Ronald. Hij kijkt bezorgd naar getallen op de monitor en weet niet goed wat te doen. Knipperend toont de monitor een grillig beeld van de bloeddruk: 55, 31, 38. 50; hartactie: 181, 167, 158, 199. $\mathrm{Hij}$ bekijkt de daglijst. Ook daar is het beeld niet beter: natrium - 124, calcium 3.2, kalium - 4.3. Hij kijkt weer op de monitor. 'Wat moet ik hier nu mee? Zie ik dan soms iets over het hoofd?' Hij besluit om extra bloedonderzoeken te laten doen. Misschien geven die getallen meer zicht op de situatie.

De arts-assistent weet niet goed hoe de situatie te beoordelen of wat te doen. Het onproblematisch traject van verzamelen en vergelijken is ineens niet langer vanzelfsprekend. Duiden de getallen op een probleem? Is er iets ernstigs aan de hand of trekt het kind zo weer bij? Zeker als een arts nog weinig ervaring op een NICU heeft, kan er sprake zijn van aarzeling. De aankomend kinderarts is geneigd de oorzaak van de onduidelijkheid bij zichzelf te zoeken. Niet de monitor of de labuitslagen zijn dubieus, maar hij zelf zou het vak nog onvoldoende beheersen. Er vindt met andere woorden een distributieproces plaats, waarbij 
hij zekerheid aan de getallen toebedeelt en de twijfel bij zichzelf legt. De vraag 'Wat is er aan de hand?' maakt plaats voor de vraag 'Wat doe ik niet goed?'

Door zijn aarzeling verliest de arts-assistent ook het zicht op het kind. Hoewel de getallen doorgaans klare taal spreken, weet de arts op dat moment niet wat hij ermee aan moet. In hun grilligheid hebben de getallen op de monitor hun oplossend vermogen verloren en zijn zelf een probleem geworden. De getallen spreken onduidelijke taal en roepen de vraag op: 'Zijn deze getallen wat ze zeggen dat ze zijn?' Deze twijfel verbreekt de eens zo vanzelfsprekende eenheid tussen kind en zijn representaties. Om zijn onzekerheid weg te nemen besluit de arts nog meer informatie te gaan verzamelen. Enerzijds wordt hierdoor de reeds bestaande complexiteit nog gecompliceerder gemaakt. Anderzijds is het zo dat getallen regelmatig als breekijzer worden ingezet om uit een impasse te komen. Als het handelingstraject is vastgelopen in een brei van gegevens, kunnen nieuwe gegevens een nieuwe impuls geven. Buisjes gevuld met bloed verdwijnen daarom opnieuw door de buizenpost. De uitslagen die via de computer terugkomen moeten uitkomst brengen.

\section{Getal versus getal}

Het numeriek instrumentarium van artsen werkt, maar alleen onder bepaalde voorwaarden. Ten eerste, de juiste interpretatie van getallen is afhankelijk van kennis en ervaring. Ten tweede, getallen dienen te passen in een patroon. Maar wat te doen als getallen elkaar tegenspreken?

\section{Academisch Centrum}

De arts-assistent bekijkt de bloeduitslagen van Tom. Ze zien er beter uit dan in de voorafgaande dagen. Tom lijkt stabiel. Of toch niet? De nieuwste bloeduitslagen lijken alweer de volgende golf van ellende aan te kondigen. De arts-assistent pleegt overleg met de attending: 'Ik vrees dat het kind weer gaat spoken. Zijn laatste bili's' schommelen tussen de so en de 200.' De attending pakt de andere uitslagen erbij. 'Dit kan nooit. Dit moet een fout van het lab zijn. Kijk maar, de andere waarden wijzen helemaal niet in die richting. Bovendien is een dergelijke schommeling onmogelijk. Doe het nog maar een keer en dan zal je zien dat het normaal is.' De arts-assistent wandelt opgelucht naar de tafel om een nicuwe aanvraag uit te schrijven in de hoop betrouwbare gegevens terug te krijgen en de vorige uitslag als foutief af te kunnen schrijven.

De artsen nemen de uitkomst van het bilirubineonderzoek niet voetstoots aan, maar beoordelen de waarde ervan in het licht van de andere gegevens over het kind. Zelfs als uitkomsten duidelijke taal spreken, blijkt de hardheid van hun feitelijkheid nog niet gegarandeerd. Of de uitslag waardevol of waardeloos is, zeker of betwijfelbaar, is hier ook afhankelijk van andere uitkomsten. De 
bestaande gegevens van het kind vormen een geheel waarin het één het ander bevestigt dan wel ondermijnt. De bilirubine-uitslag staat in deze strijd geheel alleen en mist elke bevestiging. Het sluit niet aan bij hetgeen er reeds ligt. De bilirubine-uitslag past niet in het beeld dat de andere uitslagen geven. Elke poging om de uitslag in verband te brengen met andere gegevens leidt tot fricties en maakt een goede inbedding in het bestaande geheel van informatic onmogelijk. De tweede test moet een uitslag opleveren die wel in het beeld past.

De mate waarin getallen als richtinggevend worden beschouwd, blijkt afhankelijk van kennis en ervaring, alsmede van andere getallen. In tegenstelling tot de grillige waarden op de monitor wordt de bilirubine-uitslag wel begrepen, maar niet bevestigd. Wil een uitslag als basis voor handelen dienen dan moet die verankerd zijn in een netwerk van andere gegevens. Artsen verzamelen getallen en vechten ze aan om het plaatje kloppend te krijgen. Maar wat te doen als bij herhaald onderzoek dezelfde onbegrijpelijke uitslag hardnekkig terug blijft komen?

\section{Northeastern General Hospital}

Christien ligt in een open couveuse op de NICU. Een warmtelamp boven haar houdt haar op temperatuur. Zij heeft al twee weken een hoge bloeddruk in haar rechter harthelft zonder dat men de oorzaak hiervan weet op te sporen. In het begin had de staf de hoop dat het vanzelf weg zou gaan. Het zou gaan om een persisterende foetale circulatic. Hierbij heeft de bloedsomloop nog steeds dezelfde richting als tijdens de intra-uteriene fase. Zoals altijd in dergelijke gevallen heeft men ook bij Christien de benodigde medicijnen ingezet. Dit keer echter zonder resultaat. Er wordt daarom nog meer informatie verzameld. Hoewel de hoeveelheid getallen blijft groeien, wordt het raadsel er niet minder op. Andere specialisten worden ingeschakeld. Elke aanwijzing blijft echter uit. Echo na echo, medicijn na medicijn wordt erbij gehaald. Niets helpt. Na elke meting blijkt de druk nog steeds verhoogd te zijn: 9o, 88, 96. Alle andere waarden blijven echter normaal. Iedereen staat voor een raadsel. Wanneer het ene staflid een mogelijke oorzaak oppert, wordt deze weer-met verwijzing naar de overige normale waarden - door een ander terzijde geschoven.

Getergd door tegenstrijdige waarden loopt deze staf elke dag tegen haar onvermogen op om het raadsel rond Christien op te lossen. Maar ligt de oplossing niet voor de hand? Die uitslag van die rechterkamer klopt gewoon niet. In dit geval dwingt de hardnekkigheid waarmee de uitslag blijft opduiken de staf om het getal serieus te nemen, terwijl de tegenstrijdigheid niet als onbeduidend kan worden gemarginaliseerd. De artsen trachten eerst het probleem via de bekende weg op te lossen en verzamelen meer gegevens. Medicijnen worden ingezet, de druk wordt elke keer opnieuw bepaald met verschillende apparaten, andere gegevens worden verzameld en ernaast gelegd. Maar de tegenstrijdigheid van de onderlinge getallen blijft bestaan. Daarom probeert men het kind bij een 
andere specialist onder te brengen. Die bedankt echter voor de eer, maar wil zich wel voor het probleem inzetten. Ook zonder bevredigend resultaat. Ondertussen hoopt men stilletjes dat naarmate de tijd verstrijkt, het probleem vanzelf verdwijnt. Ook dit gebeurt niet. Uiteindelijk besluit de staf het kind naar een ander ziekenhuis door te verwijzen waar men in het bezit is van andere apparatuur. Misschien kunnen ze daar het raadsel uit de wereld helpen.

Hier blijkt dat niet elke twijfel zich laat oplossen door het verzamelen van getallen. Bij alles wat men probeert blijft het beeld hetzelfde: een verhoogde bloeddruk in de rechterhartkamer in combinatie met normaalwaarden. De bloeddrukuitslag is hier te zeer verankerd in een heterogeen netwerk om het als een vergissing af te kunnen doen.

\section{Rivaliserende kaders van kennis}

Op de NICU zijn relevante kennis en ervaring niet evenredig over alle betrokkenen verdeeld. Met name voor de ouders is het vaak moeilijk in te schatten wat er allemaal gebeurt. Hoewel zij geen medische beslissingen hoeven te nemen, wil dit niet zeggen dat zij niets met de getallen doen; of beter gezegd, dat de getallen niets met hen doen.

\section{Academisch Centrum}

In de loop van de middag komen de ouders van Tom opnieuw langs. Zijn moeder lijkt uitgeput. Zij kijkt bezorgd naar de monitor. Opeens gaat het alarm. Beiden kijken verschrikt naar hun kind. De verpleegkundige is er direct bij en kijkt onmiddellijk naar de monitor. Deze toont een sterk wisselende ademhalingsfrequentie. Ze zet het alarm af en kijkt in de couveuse. De ouders kijken haar angstig aan. "Is er iets niet goed?". In de couveuse ligt Tom lekker te slapen. Het borstkasje beweegt regelmatig op en neer. Nee, met hem is niets aan de hand. Het is de elektrode die de ademhaling registreert, die voor hun paniek heeft gezorgd. De verpleegkundige laat de geschrokken ouders de losse plakker zien. Niets aan de hand. Ze plakt de elektrode opnieuw op het kind en direct verschijnt er een stabiele ademhalingsfrequentie op de monitor.

De ouders worden hier geconfronteerd met een hoge ademhalingsfrequentie die wordt begeleid door een luid alarm. Reden genoeg om te schrikken. De verpleegkundige laat zich echter niet zo snel door het getal leiden. Het getal mag nooit als vanzelfsprekend uitgangspunt van handelen dienen. De aanblik van het rustig slapende kind in de couveuse maakt het getal op de monitor onbetrouwbaar. De losse plakker op Toms lijf maakt vervolgens aannemelijk dat zijn op en neer bewegende borstkas betere informatie verschaft dan de op en neer bewegende getallen op de monitor. De ouders missen echter ervaring en kennis en laten zich begrijpelijkerwijs door het alarm van de wijs brengen. Voor de 
verpleegkundige is in het licht van de afgevallen elektrode en het klinisch beeld van het kind de distributie tussen twijfel en zekerheid snel gemaakt.

Omgekeerd zijn de klinische symptomen niet altijd bepalend. In andere gevallen, zoals bij Peter, zijn het niet zozeer kennis en ervaring of andere getallen, maar andere bronnen van kennis die doorslaggevend zijn.

\section{Northeastern General Hospital}

In de hoek van de NICU ligt Peter, cen premature baby. Zonder enige waarschuwing vooraf raakt Peter in een ernstige crisis. Direct wordt de nurse-practitioner erbij geroepen. Peter ziet er verschrikkelijk bleek uit. Inwit ligt hij in zijn couveuse. De monitor geeft een hele hoge $\mathrm{PCO}_{2}$ an, wat betekent dat het kind enorm verzuurd bloed heeft. Hij deed het tot nu toe zo goed dat zijn zuurstofslang er vanmorgen uit mocht en hij overging op cen niet-invasieve vorm van beaderning. Hoewel Peter de hele dag goede bloedgaswaarden bleef houden, lijkt hij het nu niet meer te kunnen bolwerken. De verpleging dringt aan op een reintubatic. Maar de nurse-practitioner besluit de bloeduitslagen af te wachten die toevallig net zijn weggebracht. Met spanning wacht men op de uitslag, terwijl Peter nauwlettend in de gaten wordt gehouden. Na enkele minuten is de uitslag binnen: het kind heeft uitstekende waarden. Ondertussen is ook de $\mathrm{PCO}_{2}$ gezakt. De nurse-practitioner is blij dat zij niet beeft geintubeerd.

\section{De nurse-practitioner:}

'Ik moet bekennen dat ik hem ook wel even kneep. Iedereen zei 'intuberen', maar ik heb dit vaker bij Peter zien gebeuren en hij weet er altijd zelf weer uit te klimmen. Daarom wilde ik zo lang mogelijk wachten met invasieve behandeling. $\mathrm{lk}$ besloot op de uitslag te wachten en niet direct opnieuw te intuberen omdat ik zag dat de $\mathrm{PCO}_{2}$ ging zakken. Maar je begrijpt dat als de bloeduitslagen slecht waren geweest, ik hem alsnog geïntubeerd had. Maar ik hou er niet van om dit kind te intuberen. Hij raakt altijd zo van streek dat hij opnieuw in een crisis schiet. Daar schiet je dan ook niets mee op. Het is vaak zoeken naar een oplossing. Soms kloppen de getallen zelfs niet. Je zag hoe hoog zijn $\mathrm{PCO}_{2}$ waardes waren. En je zag ook hoe intens bleek hij was. Toch was zijn saturatie perfect en de andere uitslagen ook. Soms weet je niet goed waar je op af moet gaan.'

De nurse-practitioner kiest uiteindelijk voor de minst agressieve interventie. Voor een dergelijke actie is niet zozeer moed nodig, als wel ervaring. Voor een ervaren staflid is de betekenis van getallen dan ook flexibeler dan die voor een minder ervaren staflid. Voor de neonatoloog is een getal niet zozeer 'normaal' of 'afwijkend', maar eerder 'acceptabel' of 'onacceptabel', een meer vloeiend onderscheid. Dit geeft meer ruimte om te handelen en biedt bij patstellingen een mogelijkheid om het handelingsproces vlot te trekken. 
Ook aan harde cijfers ontleende kennis laat zich niet los van de context toepassen. Er blijkt steeds sprake te zijn van situariespecifieke activiteiten en beslissingen." Hiertoe verzamelen de stafleden voortdurend getallen, berekenen zij ratio en hoeveelheden, informeren zij elkaar in een numerieke taal en rangschikken zij kwantitatieve data op speciale formulieren. Het effect van deze getallenstroom is dat lezen, schrijven en rekenen een steeds terugkerende bezigheid is die deel uitmaakt van de dagelijkse routinehandelingen op de unit. Werken op een NICU betekent voor zowel arts als verpleegkundige naast specialistische kennis en vaardigheid ook kwantitatieve behendigheid en inzicht in getallen. De NICU is een kwantitatieve praktijk waarin zowel mens als machine een bijdrage levert aan het numerieke bouwwerk dat rondom het kind wordt opgetrokken. "Niet de stethoscoop maar de rekenmachine en de pen zijn hier het meest gebruikte gereedschap.

De hier besproken voorbeelden illustreren dat de grote stroom kwantitatieve data niet kan verhinderen dat onzekerheid deel blijft uitmaken van de handelingstrajecten die men op de NICU inzet. De behandeling van Tom en Robert tonen hoe met preventieve maatregelen, voortdurende bewaking en een aanhoudende stroom kwantitatieve data de staf een kind over een uiterst riskant en complex traject heenloodst. Hoewel in het geval van Robert niet alles zonder problemen verloopt, is hij in zekere zin een ideale patiënt. Zijn behandeling laat de mogelijkheden van de neonatologie in zijn meest extreme vorm zien. Hij is aanvankelijk een kind zonder een enkele kans op overleving, maar krijgt een toekomst net als ieder ander gezond kind. Zijn situatie blijft stabiel en in korte tijd knapt hij zienderogen op. Na twee weken doet hij het zo goed dat minimale bewaking voldoende is. Hij wordt teruggeplaatst in het ziekenhuis waar hij is geboren en na een verblijf van een week mag hij naar huis, gezond en wel.

Het verloop van de behandeling van Tom laat echter zien hoe met een toename van de complexiteit van een handelingstraject soms controle ook plaats moet maken voor contingentie en machteloosheid. Zijn behandelingstraject laat zien hoe hij ondanks alle kennis, getallen en medische technologie steeds verder verwijderd raakt van het uiteindelijke doel. Op dit punt aangekomen is het optimistisch karakter dat altijd in zekere mate deel uitmaakt van de behandelingspraktijk, vrijwel volledig verdwenen. De situatic waarin hij verkeert, ligt ver af van hetgeen men voor ogen had op het moment dat de behandeling werd ingezet. De staf is er in zijn geval niet in geslaagd haar doelstelling te realiseren. Dit dwingt de staf om het doel van de behandeling te herformuleren en daarbij speelt uiteraard de prognose een centrale rol. Hoe komt men echter tot een prognose? Die vraag zal ik in het volgende hoofdstuk ter discussie stellen. 


\section{Bakens aan de horizon}

\section{Academisch Centrum}

De ouders van Tom staan naast de couveuse. Zijn vader bekijkt de daglijst. Zijn moeder draait een speelgoedbeertic op en zet het voorzichtig naast het hoofd van Tom. Echt aankijken doet hij haar niet. De muziek uit het beertje komt nauwelijks boven de andere geluiden uit: het gezoem van het beademingsapparaat, het gepiep van de monitoren, het gerinkel van de telefoon. Het maakt pijnlijk duidelijk dat het beertje gemaakt is voor de stille beslotenheid van de babykamer thuis.

Tom ligt nu al meer dan drie maanden op de NICU. Zijn toestand is de laatste dagen zeer wisselend. Zo ziet hij er goed uit en een uur later kan het beeld compleet veranderd zijn.

Dinsdag 9.30 uur: Twee verpleegkundigen staan over zijn bed gebogen. De eén houdt zijn hoofd vast, terwijl de ander met tape de zuurstoftube bevestigt. Rood van de inspanning probeert Tom de tube eruit te werken. Echter zonder succes. Met sussende woorden proberen de verpleegkundigen Tom gerust te stellen. Eveneens zonder succes. De monitor boven de couveuse knippert in een hoog tempo.

'Hij wordt steeds sterker, zeg.' De verpleegkundige verstevigt opnieuw haar grip. 'Het is notabene al de tweede keer deze week dat hij zijn tube eruit heeft gewerkt. En gisteren is zijn beademingsdruk ook weer omhoog gegaan naar 35 . Zo schieten we natuurlijk niet op. Ik vraag me af waar dit naartoe gaat.' 'Ik ben bang dat we hier een tweede Mick aan het kweken zijn. Die kregen we uiteindelijk ook niet meer van de beademing af.'

11. oo uur: Er wordt visite gelopen. Vandaag is ook de maatschappelijk werkster erbij. Ook zij kent Tom en zijn ouders. In de bespreking van Tom vraagt ze aan de neonatoloog waar de grens van behandelen ligt. Ze is duidelijk niet de enige voor wie deze vraag speelt. Ook de verpleegkundigen kijken gespannen naar de arts. De neonatoloog: 'Gezien het feit dat het kind het neurologisch nog steeds goed doet, is er geen enkele reden om het beleid te veranderen. Bovendien heeft hij theoretisch gezien nog steeds een kans om van de beademing af te komen. Alhoewel we ons wel realiseren dat deze kans steeds kleiner wordt naarmate de 
tijd verstrijkt. Dat is juist het probleem bij BPD-kinderen. Hoe langer ze aan de beademing zitten hoe moeilijker we ze er weer af krijgen. We proberen dus de druk te verminderen. Maar tot nu toe lopen deze pogingen voortdurend vast op slechte bloedgaswaarden en moeten we weer terug naar het oude niveau. Als hij echt geen enkele kans meer heeft op verbetering wordt het moeilijk en zullen we om de tafel moeten gaan zitten om het beleid te bespreken. Maar zolang er een kans is gaan we door.' Niemand heeft hier iets op te zeggen en de visite wordt vervolgd.

Tijdens de lunch komen de emoties los. Eén van de verpleegkundigen die de opleiding voor de neonatologiespecialisatie volgt, vertelt dat de situatie van Tom in de ethiekles aan de orde is gekomen:

'Tachtig procent van de verpleegkundigen wil niet meer verder met dit kind omdat hij toch nooit meer van de beademing afkomt. We blijven hem wel verzorgen, maar 's nachts kan ik er soms niet van slapen. De artsen, op Rijnders na, willen doorgaan. Met name Geert Hogebeemt wil doorgaan. Waarschijnlijk omdat hij Tom een paar weken geleden uit een crisis heeft gehaald. $\mathrm{Na}$ al die inspanning wil hij nu alles op alles zetten. Rijnders en Margreet hebben zo hun twijfels. Maar ja, hij is de jongste neonatoloog en zij is maar een arts-assistent. Ik snap niet waarom ze nog langer doorgaan. Want zeg nou zelf, hoc groot is de kans dat dit kind het overleeft en als dit zo is, over wat voor soort leven hebben we het dan?'

Ook Toms ouders zien hoe hun kind zienderogen achteruit gaat. Maar in tegenstelling tot bij de staf staat bij hen niet de slechte conditie van Tom voorop, maar zijn vermogen om daar elke keer weer uit te klimmen. Toms vader:

'We vinden de artsen soms erg pessimistisch. Al vier keer is ons verteld dat Tom het niet meer haalt. Maar tot nu toe hebben ze het iedere keer bij het verkeerde eind gehad. Misschien is hij sterker dan iedereen denkt. Daarom vinden we ook dat ze hem niet mogen opgeven. Als het een volgende keer misgaat kan hij er immers ook weer bovenop komen. Zo is het tot nu toe steeds gegaan.'

Uit het voorgaande kunnen tenminste drie visies op de prognose van Tom worden gedestilleerd. De verpleegkundige in opleiding ziet in Tom een kind zonder toekomst dat onnodig lang in leven wordt gehouden door artsen. Hij ervaart soms machteloze boosheid. Voor de attending is Tom een moeilijk te behandelen kind, maar ook een kind dat het neurologisch nog steeds goed doet en volgens de literatuur nog een kans heeft. Het staken van de behandeling is voor hem dan ook geen optie. Voor de ouders is Tom een kind dat vecht voor zijn leven en tot nu toe sterker blijkt dan iedereen verwacht. Waar de eerste weken van Toms opname werden gekenmerkt door een algemene overeenstemming, 
is deze eensgezindheid drie maanden later verdwenen. In deze periode van zijn opname lopen de beschrijvingen van Tom dus uiteen van 'een hopeloos geval', 'een kind met een kans' tot 'een kind dat sterker is dan iedereen denkt',

Hoe komen deze uiteenlopende visies tot stand? Waarom hebben de betrokkenen ieder een eigen beeld? Waar komen prognostische verschillen vandaan? Om dit te kunnen begrijpen staat in dit hoofdstuk het proces van prognosticeren centraal. In eerste instantie biedt het begrip 'positie' een goede ingang om hierover meer te kunnen zeggen. Ouders bekijken een kind met andere ogen dan stafleden. Ook artsen en verpleegkundigen beoordelen de situatic van een kind vanuit een eigen positie. De specificiteit van de blik en de door de concrete sociale context bepaalde handelingsperspectieven van de betrokkenen (artsen, verpleegkundigen en ouders) zijn direct van invloed op de in die context geconstrueerde prognostische verschillen. Om echter het bestaan van uiteenlopende prognoses binnen de groepen beter te begrijpen, zijn andere sociologische dimensies eveneens van belang. In de beleving en het gebruik van de ruimte doet men bijvoorbeeld eveneens kennis en ervaring op, die doorwerken in het proces van prognosticeren. Bovendien doen de betrokkenen tijdens het hele proces nieuwe ervaringen op, waardoor hun verwachtingen ten aanzien van de behandeling veranderen. Hierbij zijn factoren als afstand versus nabijheid, waarnemen en vergelijken, en aanraken versus afblijven in het geding. Verschillen in de wijze waarop betrokkenen deze aspecten ervaren of beleven, dragen bij aan prognostische verschillen. Tot slot blijkt uit mijn analyse dat een aantal factoren, die in meer algemene zin samenhangen met vakkennis en technologie, alsmede met de specifieke ruimteliike en temporele orde van de concrete context, ertoe bijdragen dat betrokkenen bij verschillende prognoses uitkomen.

\section{Positie en prognose}

In de strijd om het gelijk worden opvattingen van de ander al gauw psychologisch geduid. De ouders van Tom wijten de stellingname van de artsen bijvoorbeeld aan een pessimistische instelling. Op hun beurt interpreteren stafleden de positie van Toms ouders als een uiting van ontkenning. Deze ouders zouden er nog niet aan toe zijn om de realiteit onder ogen te zien of om hun kind te laten gaan. Ook de opvatting van Maureens ouders wordt op deze manier uitgelegd. Een neonatoloog uit het Northeastern vertelt:

\footnotetext{
'Tot nu toe ontkennen de ouders van Maureen de situatic, Ik wil ze in ieder geval spreken, zodat ik ze nogmaals de stand van zaken kan voorleggen. Het feit dat wij er klaar voor zijn om hier een eind aan te maken wil niet zeggen dat de ouders er ook aan toe zijn.'
} 
Ook voor de eigen onderlinge verdeeldheid van de staf heeft men een verklaring. Een verpleegkundige die voor Tom zorgt:

'Zodra er wat met Tom gebeurt trekken ze (de artsen JM) hier alles uit de kast om hem er bovenop te krijgen. Het lijkt wel of ze van geen ophouden weten. En zij wijzen weer naar de ouders. Die ouders willen dat we er alles aan doen wat we kunnen. Maar ja, hun beslissing is ook afhankelijk van hoe de situatie aan de ouders verteld worde door de artsen. Wanneer ze iets positiefs in het verhaal stoppen richten die ouders zich daar natuurlijk direct op.'

Eén van de neonatologen in het Academisch Centrum:

'Als de afdeling vol ligt met doodzieke kinderen heeft dit zijn weerslag op de verpleging. Alsof de last die dit met zich meebrengt hun draagkracht te boven gaat. Dan is een chronisch kind als Tom net de druppel die de emmer doet overlopen.'

De situatie rond Toms couveuse lijkt op die van Maureen. In het Northeastern General Hospital is ook de prognose van Maureen een punt van discussie. Ook bij haar is er sprake van een positieverdeling in voor- en tegenstanders van de continuering van haar behandeling. Bovendien vertoont de bezetting van de verschillende posities een grote gelijkenis met die in de discussie over Tom. Evenals bij Tom zijn het de ouders die aangeven dat Maureens behandeling gecontinueerd moet worden. Ook hier keren verpleegkundigen zich tegen verdere behandeling en geeft een neonatoloog aan dat het kind nog kansen heeft en dat het staken van de behandeling niet aan de orde is.'

Voorgaande beschrijvingen scheppen een beeld van ontkennende ouders, artsen met een ongebreidelde dadendrang en verpleegkundigen die zich louter door hun emoties laten leiden. Dergelijke uitspraken over en weer zijn niet aan de orde van de dag op de NICU; ze zijn meestal pas hoorbaar op momenten dat er zich daadwerkelijk serieuze meningsverschillen voordoen. De typeringen staan dan ook niet op zichzelf, maar maken deel uit van een retorische strijd. Door het beoordelingsvermogen van de ander te relateren aan zaken als angst en ontkenning wordt diens standpunt als irrationeel afgedaan en het gelijk van de eigen visie onderstreept. Maar wie heeft er gelijk? De artsen? En zijn de betrokken verpleegkundigen of de ouders te emotioneel? Of zijn de artsen te nuchter? Deze vragen doen geen recht aan de motieven van de betrokkenen, noch aan de complexiteit van de situatie. Interessanter is de vraag naar de achtergrond van de prognostische verschillen. Bovenstaande uitspraken laten zien dat de betrokkenen uiteenlopende ideeën hebben over de toekomst van het kind. Opvallend hierbij is dat de verschillen groepsgebonden lijken te zijn. Waar komen deze prognostische verschillen vandaan? Welke rol speelt de sociale of professionele positie in de bepaling van de prognose? 


\section{De specificiteit van de blik}

Het begrip 'positie' biedt een goede ingang om het ontstaan van verschillende prognoses bij uiteenlopende sociale groepen te onderzoeken, omdat het een relatic legt tussen de interpretatie van een situatie en de blikrichting van waaruit deze wordt waargenomen. ${ }^{2}$ Vanuit de ene positie wordt iets waargenomen dat vanuit een andere positie niet of maar ten dele zichtbaar is. Het begrip 'positie' kan ook verwijzen naar de plaats die iemand in een sociale orde inneemt. Wat men waarneemt is dan afhankelijk van de sociale rol die men op de afdeling inneemt. Ouders bekijken de situatie van een kind met andere ogen dan stafleden. Ouders zien in de eerste plaats hun eigen kind. De staf kijkt met een professionele blik en ziet een kind dat is opgenomen op hun afdeling. Hoewel artsen en verpleegkundigen het herstel van het kind als het gemeenschappelijke doel van hun inzet beschouwen, hebben zij hierbij elk hun eigen aandachtsgebied, respectievelijk behandeling en zorg. De verschillende posities bieden uiteenlopende kaders waarmee de werkelijkheid wordt geordend. In elk kader liggen vooronderstellingen en overtuigingen besloten die de waarneming beïnvloeden.' Op grond hiervan worden bepaalde aspecten van de situatie naar voren gehaald en anderen genegeerd. De positie bepaalt voor een deel wat er wordt gezien, wat als voor- of als achtergrond geldt en de wijze waarop dit wordt geinterpreteerd. Een andere positie toont een andere wereld, een ander kind. Hoe wordt er met deze verschillen omgegaan?

In de dagelijkse gang van zaken bestaan op de NICU de verschillende visies op een kind doorgaans onproblematisch naast elkaar. Het verschil wordt zelfs als functioneel gezien. Elke positie biedt zijn eigen kijk op de situatie van een kind. Stafleden brengen bijvoorbeeld tijdens de dagelijkse visite verschillende visies bij elkaar om zoveel mogelijk aspecten van de toestand van een kind in kaart te brengen. Door het combineren van de medische en de verpleegkundige blik zou een vollediger beeld van de situatie van het kind ontstaan. De verschillen zijn echter niet altijd complementair. Verschillende ideeën van artsen, verpleegkundigen en ouders kunnen in een rivaliserende relatie tot elkaar staan. Het gaat dan niet enkel over de verschillende posities van waaruit de situatie van het kind wordt bekeken, maar ook over strijdige interpretaties ervan. Het is opvallend dat alle partijen claimen dat zij een realistischer beeld van de situatie van een kind hebben dan de anderen. Zo zouden artsen bijvoorbeeld door hun technische kennis - lees 'wetenschappelijke objectiviteit' - een reëler beeld neerzetten dan het 'meer emotionele' blik van verpleegkundigen. Verpleegkundigen op hun beurt zouden niet alleen naar de getallen kijken en claimen op die wijze hun gelijk. Op zo'n moment wordt verschillen in visie niet meer als functioneel gezien. 
Hoewel op de NICU de verschillende visies op de toestand van het kind doorgaans als complementair worden beschouwd, komen verschuivingen naar rivaliserende verhoudingen eveneens voor. Zo'n verschuiving is duidelijk waar te nemen gedurende de behandeling van Tom. In het begin ziet iedereen op zijn eigen manier in hem een kind met een kans dat om maximale interventie vraagt. Maar de latere uitspraken van de hierboven geciteerde betrokkenen geven blijk van een meer rivaliserende verhouding. Waardoor verdwijnt tijdens de behandeling van Tom het complementaire karakter van de uiteenlopende invalshoeken? Niet omdat de betrokkenen verschillende posities innemen; dat doen ze immers altijd al: de rollen van ouders, artsen en verpleegkundigen liggen van meet af aan vast. De verschillende visies krijgen een rivaliserend karakter omdat ze strijdende handelingstrajecten veronderstellen. In het begin van de opname van Tom is er wel overeenstemming over het traject. Op dat moment ligt zijn toekomst nog open. Met die onzekerheid kan iedereen leven en de behandeling wordt gestart. Als zich na enkele weken de problemen opstapelen, krijgt de staf steeds minder grip op Toms situatie.' Zijn behandeling blijkt allesbehalve een routinekwestic en de uitkomst wordt steeds minder duidelijk. Deze twijfel geeft ruimte voor verschillende interpretaties van hetgeen er in het verschiet ligt. De overeenstemming over de prognose brokkelt echter steeds verder af. Voor zijn ouders ontpopt Tom zich tot een vechtersbaas, die de volgende crisis ook weer te boven zal komen. Een ander handelingstraject is voor hen dan ook niet aan de orde. Hoewel de behandelend arts zich niet in deze optimistische visie van de ouders kan vinden, is ook volgens hem een radicale koerswijziging nog niet noodzakelijk. Theoretisch gezien heeft de behandeling immers nog steeds kans van slagen. Hoewel arts en ouders er een verschillende prognose op nahouden, prefereren zij wel hetzelfde handelingstraject. Dit in tegenstelling tot enkele verpleegkundigen. $\mathrm{Zij}$ hebben niet alleen een andere visie op Toms toekomst, maar hun prognose impliceert een radicale koerswijziging in het behandelingsbeleid. Waar de arts en de ouders nog de ingezette route (continuering van de behandeling) willen volgen, wijzen deze verpleegkundigen op grond van hun prognose in een geheel andere richting (het staken van de behandeling). De verschillende prognoses blijken rivaliserende handelingstrajecten te impliceren en hiermee verdween het complementaire karakter van de verschillende invalshoeken.

\section{De specificiteit van het handelen}

Het bestaan van verschillende posities maakt het ontstaan van uiteenlopende prognoses inzichtelijk. De specifieke positie van de betrokkenen bepaalt wat zij kunnen zien. Dit is echter slechts een deel van het verhaal. De positie bepaalt namelijk ook wat zij kunnen doen. Door het handelingsniveau in de analyse van 
de gebezigde prognoses te betrekken, krijgt het begrip 'positic' een theoretische verdieping die haar verklarende kracht ten goede komt.' De bepaling van een prognose blijkt dan nauw samen te hangen met de taken die aan de verschillende sociale posities gekoppeld zijn.

De positie van de betrokkenen op de afdeling gaar gepaard met concrete taken en verantwoordelijkheden. Zo richten artsen zich primair op diagnose en behandeling (cure) en verpleegkundigen op zorg (care). Deze klassieke indeling is op de NICU echter minder evident. Hier kan het verschil tussen artsen en verpleegkundigen lang niet altijd worden teruggebracht tot de 'cure-care' tegenstelling, omdat NICU-verpleegkundigen ook veel behandelingstaken verrichten. Dit wil overigens niet zeggen dat er op de NICU geen taakverdeling tussen artsen en verpleegkundigen bestaat.

Doordat verschillende werkzaamheden toegang bieden tot uiteenlopende informatiebronnen, ontstaat er bij de verschillende betrokkenen andersoortige kennis over een kind. Zo draagt bijvoorbeeld de output van diagnostische apparatuur, zoals uitslagen van bloedtesten, de getallen op de monitor, echo's en röntgenfoto's bij tot wat als 'technische kennis' benoemd kan worden. Terwijl directe waarneming in de zin van kijken, luisteren en voelen tot 'observationele kennis' leidt. 'Interactieve kennis', tenslotte, vloeit voort uit het sociale contact met het kind. De mate waarin de betrokkenen gebruik (kunnen) maken van deze verschillende soorten kennis blijkt nauw samen te hangen met hun taakstelling. Zo hebben bijvoorbeeld neonatologen meer technische kennis dan interactieve kennis. Verpleegkundigen daarentegen hebben door hun werkzaamheden toegang tot alle drie de soorten kennis. Kortom, verschillende rollen leiden tot uiteenlopende werkzaamheden die verschillende soorten kennis opleveren voor de inschatting van de situatie van het kind. Deze kennis kan niet los gezien worden van de organisatiestructuur waarin zij tot stand komt." Inzicht in de consequenties van verschillende professionele posities maakt zo het bestaan van prognostische verschillen beter inzichtelijk.

\section{Een topografie van ervaring}

Door de aandacht te vestigen op de koppeling tussen sociale positic en prognostische kennis ontstaat het gevaar dat de formulering van uiteenlopende prognoses louter wordt gezien als een groepsgebonden aangelegenheid, waarbij de rollen als in een kant en klaar draaiboek op voorhand vastliggen. Dit impliceert dat er sprake zou zijn van een duidelijk omschreven, reeds gegeven definitie van de betrokkenen en van hun functies. Dit betekent dat het er niet toe zou doen wie bij welk kind de rolbezetting voor zijn rekening neemt, maar in welke functie iemand deelneemt aan de gebeurtenissen. Op die manier blijven echter de 
specificiteit van de situatie, de geschiedenis van de afdeling en de persoonlijke kennis en ervaring onderbelicht. Hoewel in de praktijk een verschil in opvatting over de prognose van een kind vaak is gelieerd aan de functie van de betrokkenen, doen zich ook situaties voor waarbij het benadrukken van de specificiteit van rollen onvoldoende inzicht oplevert. Dit is onmiddellijk duidelijk wanneer we bijvoorbeeld het bestaan van prognostische verschillen tussen verpleegkundigen onderling willen begrijpen. Waar komen deze prognostische verschillen vandaan die immers niet uit verschillen in professionele functie of sociale rol van de betrokkenen kunnen worden verklaard?

Een antwoord op deze vraag vereist dat het begrip 'positie' als analytische ingang wordt losgelaten. Om recht te doen aan de inbreng van individuelekennis en ervaring van alle betrokkenen in het proces van prognosticeren, inclusief de ouders, is een andere analytische categorie noodzakelijk. Alvorens hier nader op in te kunnen gaan, is het van belang kort stil te staan bij wat eigenlijk een prognose behelst.

In de context van de NICU is een prognose een uitspraak over de vermoedelijke afloop van een behandeling. Het is een formulering van een verwachting over wat komen gaat. Deze verwachting is veelal gebaseerd op ervaring. Ervaring en verwachting zijn hier feitelijk een onafscheidelijk duo: er bestaat geen verwachting zonder ervaring en geen ervaring zonder verwachting.' Alle betrokkenen bevinden zich in het spanningsveld tussen ervaring en verwachting op basis waarvan zij hun prognose vormen en articuleren. Daarbij is niet alleen kennis in het geding die voortvlocit uit opleiding of functie, maar ook kennis die op basis van allerlei soorten ervaringen met het kind en met elkaar wordt opgedaan. Ook door de manier waarop de betrokkenen zich tot het kind verhouden - hoe zij ermee omgaan, wat zij ervan weten, wat zij ervoor voelen, hoe zij ervoor spreken - ontstaat kennis en ervaring op basis waarvan de situatie van het kind wordt beoordeeld. Onderzoek naar de wijze waarop de betrokkenen zich tot Tom verhouden, kan uitgaan van vragen omtrent rolverdeling en functie en de direct daaraan gerelateerde kennis en prognose, maar vragen over de individuele betekenis van de omgang met en de verhouding tot het kind zijn hier evenzeer relevant. Behalve professionele kennis, die veelal ontstaat op basis van opleiding, vakliteratuur en overleg, bestaat er ook kennis en ervaring die gebaseerd is op de persoonlijke omgang met het kind en met elkaar. Door de aandacht te richten op de wijze waarop men met het kind en met elkaar omgaat, ontstaat er ruimte in de analyse voor de individualiteit van de betrokkenen als ook voor andere factoren die een rol spelen in de totstandkoming van de prognose, zoals het tijdsduur van bepaalde situaties en emoties zoals frustratie en hoop.' Onderzoek naar de wijze waarop men met het kind en elkaar omgaat, kan worden geconceptualiseerd in termen van afstand en nabijheid, kijken en vergelijken, aanraken en afblijven. 


\section{Afstand en nabijheid}

Wanneer we de concrete bewegingen van de betrokkenen bij een kind op de NICU afietten langs een tijdsas en een geografische as, dan kunnen we zien dat de eén, bijvoorbeeld een ouder, steeds zo dicht mogelijk in de buurt van het kind blijft, terwijl een ander, zoals een maatschappelijk werker, het kind altijd vanaf een afstand volgt. Welke rol spelen deze factoren precies bij de totstandkoming van de prognose van het kind? Hoe kunnen de bewegingscoördinaten in kaart worden gebracht?

Op de NICU concentreren de bewegingen van ouders zich voornamelijk rond de couveuse. $\mathrm{Na}$ binnenkomst wandelen ze linea recta naar de couveuse van hun kind. In de meeste gevallen blijven ze daar gedurende het hele bezoek. Veel ouders brengen zo dagelijks vele uren in de directe nabijheid van hun kind door. De coördinaten van de ouders blijken vlakbij die van de verpleegkundigen te liggen. Ook zij verblijven langdurig dichtbij de couveuse. Voor ouders is het contact met verpleegkundigen dan ook de belangrijkste bron van informatie en dit werkt door in hun verwachtingen over wat komen gaat. Voor het uitvoeren en bepalen van het behandelingsbeleid beperken artsen hun bewegingen niet tot de directe nabijheid van de couveuse. Zij zijn immers niet verantwoordelijk voor één of twee kinderen maar voor alle kinderen op de NICU. Artsen bewegen zich dan ook over de hele NICU en daarbuiten: in de ouderkamer van de afdeling, op de gang, in het secretariaat, in het conferentiezaaltje waar de referaten worden gehouden, in de bibliotheek en op de afdeling Radiologie russen de meest recente röntgenfoto's.

Deze beschrijving van het algemene bewegingspatroon van de verschillende groepen die we op de NICU aantreffen, kunnen we nuanceren door deze te koppelen aan specifieke gevallen. Zo komen de ouders van Tom dagelijks op bezoek, meestal in de middag rond twee uur. De eerste maanden komen zijn vader en moeder samen. Later komt zijn vader in verband met zijn werk meestal 's avonds. Zijn moeder heeft zich gedurende de opname van Tom op haar werk ziek gemeld en komt altijd overdag, soms in gezelschap van zijn oma. $\mathrm{Na}$ binnenkomst wandelen zijn ouders linea recta naar de couveuse en blijven daar gedurende het hele bezoek. Van nog geen meter afstand nemen ze zo zijn situatie in ogenschouw. Ze kijken in de couveuse, op de monitor, op de daglijst en vergelijken zijn situatie met de dag ervoor. Welke kant gaat het op? Vooruit of achteruit? Gaat het beter of slechter? Vele maanden lang zitten zij zo iedere dag uren naast zijn couveuse. Daar ontmoeten zij de verpleegkundige die op die dag de zorg voor Tom heeft. Niet alleen voor ouders is dit contact belangrijk. Verpleegkundigen vormen zich hier ook een beeld van de ouders.

De artsen zijn minder in de nabijheid van Tom te vinden. Dit is echter anders in het geval van Robert. In de eerste dagen na zijn operatie wijken ook de 
artsen geen moment van zijn zijde. De constante nabijheid van de staf is zichtbaar in het feit dat de verpleegkundigen er zelfs een kruk bij hebben genomen. Zo kunnen ze beter de daglijst invullen. Stafleden zitten zelden naast een couveuse. Doorgaans zijn het alleen ouders die naast een couveuse zitten. Ook de ouders van Robert zijn veel bij de couveuse te vinden. Maar anders dan Toms ouders blijven zij daar geen uren. Daarvoor is zijn aanblik voor hen te belastend. Ook zitten zij niet naast de couveuse. Daarvoor is nauwelijks plaats. Machines en stafleden nemen een groot deel van de ruimte in beslag. Roberts ouders zijn dan wel niet langdurig bij zijn couveuse te vinden, ze zijn er wel vaak en op de meest uiteenlopende momenten. De eerste dagen blijven ze in het ziekenhuis overnachten en zijn ze ook op minder gangbare bezoektijden naast de couveuse te vinden. Bijvoorbeeld om drie uur's nachts. Hun constante aanwezigheid in het ziekenhuis leidt tot een intens contact tussen hen en de staf.

De vele uren die artsen en verpleegkundigen op Roberts handelingstraject doorbrengen, maakt hen tot een hecht team rond de couveuse. Het samenvallen van de bewegingscoördinaten van de betrokkenen betekent echter niet per definitie een goede onderlinge verstandhouding. Naast de couveuse van Maureen zijn voortdurend een verpleegkundige en een neonatoloog te vinden. Anders dan bij Robert is hier helemaal geen sprake van een gevoel van gezamenlijkheid. De ouders van Maureen zijn er bovendien nooit. $\mathrm{Zij}$ geven de voorkeur aan afstand en zitten thuis naast de telefoon. $\mathrm{Zij}$ nemen niet zelf de situatie van hun dochter in ogenschouw, maar horen per telefoon wat de diverse artsen over haar vertellen. Toms ouders beschikken daarentegen over verschillende.kennishonnen: hun aanwerigheid sbservaties s, n. intecacties leiden tot een andere beleving dan die van de ouders van Maureen.

Ook voor de verpleegkundigen zijn er variaties mogelijk op het algemene bewegingspatroon. Er zijn in dit verband bijvoorbeeld evidente organisatorische verschillen tussen het Northeastern General Hospital en het Academisch Centrum. In het Northeastern duurt een verpleegkundige dienst twaalf uur en is het werk georganiseerd op basis van primary nursing. Dit betekent dat een verpleegkundige de primaire verantwoordelijkheid krijgt over de zorg van één kind. Het voordeel hiervan is de continuïteit van de zorg. Doordat verpleegkundigen veel tijd doorbrengen met hetzelfde kind verwerven zij specifieke kennis. Zij weten eerder wat het wil, wanneer het zich wel of niet goed voelt. Hun langdurige nabijheid geeft hen 'als geen ander' kennis over het kind en het traject dat het aflegt. Dit bevordert het persoonlijke contact met ouders en het biedt artsen een duidelijk aanspreekpunt voor informatie over een kind. Zoals één van de verpleegkundigen in het Northeastern opmerkt: 
'Je doet je best om het kind de beste zorg te geven die je kunt. Doordat je steeds voor het kind zorgt weet je ook heel goed wat er met hem aan de hand is. Je volgt als geen ander het medisch verloop van dat kind. Maar je leert het kind ook heel goed kennen. Je weet dus wat het wel of niet prettig vindt.

Natuurlijk raak je ook verknocht aan zo'n kind. Het is dan een beetje alsof het er één van jezelf is. En je raakt ook betrokken bij de ouders. Ook die zie je haast elke dag. Het is een voortdurend balanceren tussen emotionele betrokkenheid en de wetenschap dat hij straks naar huis gaat. Tenminste, als alles goed gaat.'

In het Academisch Centrum gaat de verpleegkundige zorg uit van een achturige dienst en van teamverpleging in plaats van een eén op één relatie tussen verpleegkundige en kind. Dit betekent onder meer dat geen enkele verplecgkundige exclusieve verantwoordelijkheid voor de zorg van een kind draagt. Er wordt gestreefd naar een balans tussen continuïteit en roulatic. Men mag wel drie of vier dagen achter elkaar voor hetzelfde kind zorgen, maar geen weken achter elkaar. Bovendien rouleren de verpleegkundigen ook over de high care en de medium care units. Dit beleid draagt bij aan het voorkomen van emotionele overbelasting. Dat dit inderdaad effect sorteert, blijkt wellicht uit het feit dat in het Northeastern General verpleegkundigen geregeld onder zware emotionele druk staan. Bij de opname van een kind kan niet voorzien worden hoe lang het op de afdeling zal verblijven. Wanneer een verpleegkundige vele maanden lang voor hetzelfde kind zorgt, kan er een emotionele band ontstaan die zo groot is dat de verpleegkundige zich gaat identificeren met de ouders.

Dit is bijvoorbeeld de ervaring van Beth ten tijde van haar verpleging van Dave. Net als zijn ouders gelooft Beth dat Dave op een dag naar huis zal kunnen gaan. Hoewel de andere verpleegkundigen op de afdeling deze prognose niet delen, is er wel begrip voor haar standpunt, want de ervaring leert dat de zorg voor een chronisch kind meestal gepaard gaat met een hoge mate van betrokkenheid. De verpleegkundige staf is zich bewust hoe zich dit proces bij Beth ontwikkelt en is dus voorbereid om hun collega op te vangen. Zoals één van de stafleden zegt:

'Het is duidelijk dat Beth de hopeloze situatic van Dave ontkent. Maar we hebben hier haast allemaal wel eens een chronisch kind onder onze hoede gehad en weten daarom wat het is. Als je er zelf middenin zit, heb je niet door hoe vast je aan zo'n kind zit. Pas als het te laat is heb je door hoezeer je je aan hem gebonden hebt. Het is alsof het je eigen baby is. Alsof je eigen kind daar ligt te sterven. Ik kon het ook niet verkroppen als iemand anders voor hem moest zorgen, omdat ik er niet was of omdat ik op een andere unit stond. Dit gaf enorme spanningen. $\mathrm{Nu}$ zit Beth in zo'n situatie. Haar hele leven draait nu om Dave. We hebben geprobeerd om haar meer afstand te laten nemen door haar voor een ander kind 
te laten zorgen. Maar dat wil ze juist niet, want zij alleen zorgt echt goed voor Dave, is haar idec. We laten haar daarom maar en proberen haar nu zoveel mogelijk op te vangen. Maar straks als het kind uiteindelijk is overleden heeft ze ons het hardst nodig. Want dan klapt ze helemaal in.

Sommigen van ons proberen haar te helpen door haar erop te wijzen dat ze zich moet voorbereiden op het feit dat het eventueel misgaat. Maar daar voelt Beth zich helemaal niet door geholpen. Ze weet dat dat risico erin zit en dat hoeft niemand haar te vertellen. Ze is deze dagen bijzonder snel geagiteerd. Gisteren had ze Dave op schoot toen we visite liepen. Toen één van de arts-assistenten opmerkte dat hij zo blauw zag, kreeg hij de wind van voren van haar. Dave zag volgens haar helemaal niet blauw, maar het kwam door het TL-licht. Tja, wat moet je dan zeggen.

Hoewel verpleegkundige zorg volgens het systeem van primary mursing juist goed zicht op de situatie van het kind veronderstelt, blijkt ook enige distantie belangrijk. ${ }^{\circ}$ Beth staat volgens haar collega's te dicht bij het kind. Zij is in hun ogen op de plek van de ouders gaan staan en dit vertroebelt haar professionele blik."

In bovenstaand voorbeeld zijn tijd en plaats direct gekoppeld aan betrokkenheid. Er wordt uitgegaan van de gedachte dat een hoge condensatie van plaats en tijd de gradatie van betrokkenheid doet toenemen; heel veel contact en heel veel nabijheid leidt onvermijdelijk tot een grote mate van betrokkenheid. De bewegingen rond de couveuse zijn zo bepalend voor de bewogenheid. Deze conclusie is echter voorbarig. De bewegingscoördinaten kunnen niet altijd automatisch worden vertaald in graden van betrokkenheid. Een arts is verantwoordelijk voor alle kinderen op de NICU, waardoor deze doorgaans minder tijd naast de couveuse van een kind doorbrengt dan een verpleegkundige. Artsen zijn echter ook op andere plekken, zoals aan tafel, met een kind bezig.

Hoewel ouders niet altijd bij hun kind op de afdeling zijn, zijn ze doorgaans voortdurend op het kind betrokken. Ongeacht waar ze zich bevinden, het kind reist met hen mee. Een neonatoloog in het Academisch Centrum vertelt hierover:

'Ouders raken in een koker. Alles draait om hun kind, ongeacht waar ze zijn. Of ze nu thuis of op de afdeling zijn. Of het nu dag of nacht is. Het maakt niet uit welk moment van de dag. Ouders mogen ook 's nachts bellen. En dat doen ze ook. Het kind neemt ouders de afdeling mee op en de ouders nemen de afdeling mee naar huis. De wereld van de ouders versmalt zich tot het afdelingsgebeuren, ongeacht waar ze zijn. De angst voor alles wat er mis kan gaan, leeft voortdurend bij de ouders van deze kinderen. Niet alleen als ze bij hun kind zijn, maar ook, en misschien zelfs nog meer, als ze thuis zijn en geen zicht op de gebeurtenissen op de afdeling hebben. Zij worden niet alleen deel van de ziekenhuiswereld, maar het 
zickenhuis wordt ook hun wereld. Ze zijn hier of thuis. En als ze thuis zijn, zijn $z e$ met hun gedachten hier. Hun wereld verengt zich en de dagelijkse dingen nemen groteske vormen aan: de telefoon kan de boodschapper van de meest verschrikkelijke berichten worden en er wordt zo min mogelijk gebruik van gemaakt, want de lijn moet vtij blijven. De dagelijkse gang naar het ziekenhuis vormt een ondraaglijke spanningsboog. Elke dag weer die vraag: "hoe zou het er mee zijn? Beter of slechter? Elke dag weer de gang naar het ziekenhuis, daar zijn, weer weggaan, thuis zijn en wachten op wat komen gat. Er lijkt geen ontsnappen aan. De ouders hebben geen dienstrooster met vrije dagen waar ze naar kunnen uitkijken.

De roestand van hun kind domineert doorgaans het dagelijks leven van de ouders volledig. De scheidslijn tussen de wereld van het ziekenhuis en hun persoonlijke wereld vervaagt. Het leven op de NICU reikt verder dan de muren van de afdeling en dringt zich overal aan de ouders op.

Ook stafleden nemen de situatic van een kind soms mee naar huis. Zo vertelt een verpleegkundige in het Academisch Centrum:

'Er zijn mensen die lopen de afdeling af en denken nergens meer aan. Ik heb dat zelf helemaal niet. Het liefste zou ik's avonds willen opbellen om te vragen hoe het gaat. Maar ik hou me dan in, anders zeggen je collega's: die is gestoord, die gaat in haar vrije tijd de afdeling bellen om naar de kinderen te vragen. Morgen ga ik voor vier weken op vakantic. En ik moet je bekennen dat ik er niet aan moet denken dat er iemand anders aan mijn kind zit. Want zo voel ik het nu: mijn kind. Ik zorg de hele dag alleen voor dit kind.'

De mate waarin men de kinderen 'mee naar huis neemt' blijkt niet voor iedereen gelijk. Sommige stafleden kunnen 'er 's nachts niet van slapen'. Anderen 'lopen de afdeling af en denken nergens meer aan'. Deze onderlinge verschillen impliceren dat afstand versus nabijheid niet louter een kwestic is van de professionele rol. Ook onder artsen bestaan er verschillen in de mate waarin ze de situatie van het kind op de NICU met zich mee naar huis nemen. Bij ouders wordt verregaande betrokkenheid echter uitgelegd als een manifestatie van gezonde ouderlijke betrokkenheid. Ouders behoren zich ook thuis te bekommeren om hun kind en de afdeling te bellen als ze thuis zijn. Voor stafleden gelden andere regels. $\mathrm{Zij}$ mogen thuis reflecteren op de situatie van een kind, maar daar moet het bij blijven. De afdeling bellen of in de vrije tijd de afdeling bezoeken, past niet bij hun professionele rol.

Zowel de fysieke afstand als de emotionele nabijheid kleuren de verwachtingen over het verloop van een behandeling. Sommigen zijn zich hier nadrukkelijk van bewust. Zoals Toms vader: 
'Zodra we thuis waren en alles op een rijtje hadden gezer, dachten we er goed aan te doen om de artsen te vragen met de behandeling te stoppen. Als je thuis zit is het een beslissing die theoretisch gekleurd wordt. Maar als je dan weer op de afdeling bent en je ziet zo'n kind, dan weet je het niet meer. Op zo'n moment kun je je niet voorstellen, dat je nog geen uur geleden besloten had dat het beter was om je kind te laten sterven.'

De directe aanblik van hun kind en de emotionaliteit die hiermee verbonden is, zetten het eerder genomen besluit van Toms ouders onder druk. In de huiselijke omgeving gelden andere wetten, keuzes en prognoses dan naast de couveuse van hun kind.

\section{Kijken en vergelijken}

Prognoses over de fysieke toekomst van het kind ontstaan ook in de directe waarneming. Dat wat men van het kind te zien krijgt, speelt door in het proces van prognosticeren. Niet iedereen 'observeert' het kind op dezelfde manier of even lang. Het zijn vooral de verpleegkundigen die het kind voortdurend observeren, het is misschien wel hun belangrijkste taak. Dit betekent kijken en nog eens kijken, naar het kind zelf en naar de apparatuur die rond de couveuse staat opgesteld. Zij beschouwen zichzelf niet zozeer 'de handen' maar 'de ogen van de arts'." Zij ontwikkelen na verloop van tijd hun eigen klinische blik. Ze krijgen oog voor details, nemen veranderingen waar in de houding van het

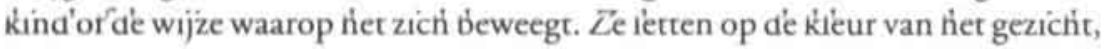
de omvang van het hoofd en hoe het de voeding verdraagt. Heeft het kind een gezwollen buik? Staan de fontanellen bol of zijn ze ingevallen? De verpleegkundigen observeren de wijze waarop het kind reageert op dagelijkse handelingen, of het onrustig is of juist apathisch. Het zijn deze doorgaans moeilijk te kwantificeren fysiologische aspecten die stafleden meenemen in de bepaling van de prognose."

Op basis van jarenlange ervaring ontwikkelt zich een gevoelsmatig inzicht: intuïtie. Ook deze vorm van kennis speelt een belangrijke rol in de totstandkoming van een prognose. Een ervaren verpleegkundige of arts 'voelt dat er iets niet in orde is met het kind' of 'ziet dat her kind er niet goed bij ligt'. Ook de verpleegkundige die voor Tom zorgt 'weet' op een gegeven moment 'hoe laat het is' en dat het duidelijk is dat hij 'nooit meer van de beademing af zal komen.' Een oordeel dat mede gebaseerd is op intuïtieve kennis laat zich moeilijk onderbouwen. Hoewel deze vorm van kennis nier lijkt te passen in het rationele beeld dat we van de professionele medische blik hebben, wordt het belang van deze vorm van kennis op de afdeling niet onderschat. ${ }^{4}$ Zeker waar het de bewaking van de toestand van het kind betreft, hebben niet alleen de getallen op de moni- 
tor betekenis, maar is ook de ervaren blik van de verpleegkundigen van belang. Dit wil niet zeggen dat zij ongericht observeren. Wat zien de verpleegkundigen in die uren die zij naast de couveuse van Tom doorbrengen?

Zij zien een kind dat slaapt onder invloed van kalmeringsmiddelen; dat worstelt met zijn beademingstube; dat het benauwd heeft als gevolg van het slijm in zijn keel; dat hoest en huilt zonder geluid. $\mathrm{Zij}$ zien een kind dat bleek is van moeheid of rood van inspanning en bij wie rust en onrust elkaar afwisselen. Zij zien getallen op de monitor en de laboratoriumuitslagen, die zich in Toms geval nooit lang genoeg in de goede richting bewegen om ze als tekens van verbetering te kunnen beschouwen. Deze opeenstapeling van dagelijkse impressies en observaties is voor de verpleegkundigen, die weken achtereen bij de verzorging van Tom betrokken zijn, aanleiding om in hem op een zeker moment een kind te zien dat zich te vaak, in de meest ruime betekenis van het woord 'niet goed' voclt om er nog bovenop te komen.

De vele uren dat artsen en verpleegkundigen zieke kinderen onder ogen hebben, brengt echter ook een zekere gewenning met zich mee. Stafleden observeren het uiterlijk van een kind met andere ogen dan ouders. De ouders van Robert reageren geschokt als zij hem na zijn operatie weer op de NICU van het Academisch Centrum terugzien. Robert is zijn eerste nacht postoperatief goed doorgekomen. Twee verpleegkundigen zijn druk met hem in de weer, terwijl zijn vader vanaf de gang door het glas naar binnen kijkt. Na een tijdje gaat hij naar binnen en zegt één van de verpleegkundigen enthousiast: 'Hij ziet er nu goed uit, nietwaar.' Roberts vader reageert verbaasd. Hij kan nauwelijks iets van zijn kind zien: zijn zoon zit nog onder het bloed en jodium en er zijn slangen die overal in en uit lijken te gaan. Een kindercardioloog geeft als commentaar op zo'n situatie: 'We zijn al zo geconditioneerd dat we het allemaal niet meer zien. Natuurlijk, het kind ziet er in wezen verschrikkelijk gehavend uit.'

De aanblik van hun kind geeft Roberts ouders allesbehalve hoop voor de toekomst. Door de vele machines rond zijn couveuse, de slangen en draden, het verband, de pleisters en rode sporen op zijn lichaam, zien ze hun kind niet meer. De moeder van het kind naast Robert vindt zijn aanblik ronduit beangstigend. Wanneer zij als gevolg hiervan niet meer bij haar eigen kind op bezoek durft te komen, wordt er bij elk bezoek van haar tussen de couveuse van haar kind en die van Robert een scherm geplaatst, zodat ze Robert niet hoeft te zien. Deze oplossing werkt uiteraard niet als het een eigen kind van ouders betreft. In sommige gevallen kan alle steun en zorg van stafleden niet voorkomen dat ouders de aanblik van hun kind niet kunnen verwerken, waarna ze de afdeling in verbijstering verlaten. Een enkeling wil zelfs nooit meer terugkomen.

Het komt ook voor dat stafleden moeite hebben met de manier waarop het kind eruit ziet. In unit C van de NICU van het Northeastern ligt een kind met ernstige misvormingen als gevolg van het Syndroom van Turner*. De moeder 
laat zich echter door niets weerhouden en geeft zich volledig aan het kind. Voor de staf ligt het anders. Hier schiet elke gewenning tekort. Het kind is zo misvormd dat het model van primary nursing wordt losgelaten en het kind elke dag door een andere verpleegkundige wordt verzorgd. De verpleegkundigen ervaren het als belastend om twaalf uur lang voor dit kind te zorgen. Extreme misvormingen kunnen zelfs het 'menselijke' aspect van het kind onder druk zetten." Met name misvormingen in het gezicht kunnen een onoverkomelijke barrière opwerpen om een emotionele band met het kind aan te gaan. Zonder het vertrouwde mensbeeld ontbreekt de verwantschap die als ankerpunt dient voor het aangaan van een emotionele band met een kind. Deze en andere indrukken die een directe confrontatie met een kind achterlaat, zijn eveneens van invloed op het proces van prognosticeren.

\section{Aanraken en afblijven}

Stafleden verwerven niet alleen kennis op basis van de vele kinderen die zij onder ogen hebben, maar ook op basis van concrete handelingen. In de vingertoppen ontwikkelt zich bij artsen en verpleegkundigen een tactiele vorm van kennis, die van belang is voor de inschatting van de situatie van een kind. Zij nemen minieme veranderingen in spiertonus, de afmeting van organen en de fysieke reacties van het kind waar, die vervolgens mede hun beeld van het kind en zijn fysieke conditie in de nabije toekomst bepalen.

Er zijn allerlei handelingen die de staf uitvoert waarbij een kind wordt aangeraakt, zoals het beluisteren van het hart, het meten van de temperatuur, het uitzuigen van de mond, het fixeren van de tube van de beademingsslang, het bekloppen van de borst, het wassen en wegen van een kind, het beoordelen van de lever of de bloeddoorstroom, het opplakken van elektrodes en het inbrengen van een infuus. Dit zijn allemaal hands-on ervaringen. In sommige gevallen is de conditie van het kind zo slecht dat elke aanraking een risico vormt. Dan is minimal handling vereist en geldt een hands-off beleid. ${ }^{16}$ In het geval van Robert is hiervan sprake tijdens de eerste dagen na zijn hartoperatie. Hij mag letterlijk met geen vinger worden aangeraakt. Zelfs de jodiumvlekken durft men niet van hem af te wassen.

Hoewel de minder zieke kinderen wel worden gestreeld, heeft negentig procent van de aanrakingen een functioneel karakter." Veel van de dagelijkse procedures zijn voor kinderen belastend. Het dagelijks lichamelijk onderzoek en de spalk aan de arm om het infuus op zijn plaats te houden kunnen tot veel ongemak leiden. Het intuberen van de beademingsslang, het uitzuigen van de mondholte, injecties en puncties kunnen een kind zelfs destabiliseren. Het zijn allemaal routinehandelingen, die een kind echter in een situatie van stress kunnen brengen." Pijnstillers en kalmeringsmiddelen kunnen dit maar voor een 
deel ondervangen." Op den duur krijgt een kind slaapproblemen, wordt het onrustig en huilt veel." Zeker chronische kinderen hebben zoveel negatieve ervaringen dat ze zeer gestrest op elke prikkel reageren. Dit geeft problemen bij de verzorging. In het geval van Tom is op een zeker moment elke aanraking te veel. Op schoot zitten is er al helemaal niet meer bij. Als zijn moeder hem op schoot neemt, raakt hij volledig in paniek. Wat als cen gezellig samenzijn bedoeld is, ontpopt zich als een riskante situatie. Voor de ouders van Tom betekent dit dat hun ouderlijke rol is teruggebracht tot die van toeschouwer. Zijn paniek is een gevolg van een te grote hoeveelheid pijnlijke ervaringen.

Op dit punt komen de verpleegkundigen zichzelf voortdurend tegen. Zoals een van hen vertelt:

'Ondanks onze maximale zorg kunnen we zijn leed nauwelijks verlichten. Tom is al zo vaak geprikt, dat hij bij elke aanraking - hoe goed ook bedoeld - over zijn toeren raakt. We kunnen niet meer voor hem doen dan zijn ellende zoveel mogelijk proberen te verminderen. Maar de mogelijkheden hiertoc lijken langzaam maar zeker uitgeput te raken.'

De verzorging van Tom betekent per definitie dat verpleegkundigen hem op allerlei manieren moeten aanraken. $\mathrm{Ze}$ moeten hem vasthouden als hij wordt gewassen en verschoond en ze verstevigen hun grip als ze zijn zuurstoftube opnieuw fixeren met een pleister op zijn bovenlip. Ze moeten ook in hem prikken voor de afname van bloed voor laboratoriumonderzoek. Als de verpleegkundigen Tom proberen te kalmeren, dragen zij ongewild bij aan zijn angst. Enerzijds proberen de verpleegkundigen een situatie te creëren waarin hij, voorzover de omstandigheden dat toelaten, zich zo prettig mogelijk voelt. Anderzijds draagt juist de uitvoering van hun werk er toe bij dat hij gestrest raakt. Hier lopen de verpleegkundigen tegen grenzen aan. Keer op keer moeten zij machteloos toezien hoe ondanks al hun inspanning, toch niet het gewenste resultaat wordt bereikt. Hun maximale inzet heeft een minimaal effect en dit vraagt om een uitzonderlijk uithoudingsvermogen. $\mathrm{Na}$ drie maanden is voor de meeste verpleegkundigen die vaak voor Tom zorgen de grens bereikt. De confrontatie met zijn dagelijkse worsteling beïnvloedt hun visie op de toekomst van dit kind. Verpleegkundigen hebben niet alleen andere verantwoordelijkheden dan artsen; zij hebben eveneens hun eigen problemen, risico's, frustraties en dilemma's. Bij het zoeken naar alternatieve oplossingen, vinden ze die steeds minder.

Zo valt de verzorging van Tom hen steeds zwaarder. Zijn angstige gedrag is kenmerkend voor kinderen die lang op de NICU verblijven. Ook Dave ligt al maanden op de NICU van het Northeastern. Een verpleegkundige in het Northeastern zegt over zijn verzorging: 
'Ik zorg eigenlijk liever voor andere kinderen. Kinderen als Dave zijn zo snel geagiteerd. Er hoeft maar iets te gebeuren of ze zijn al uit balans. Dave loopt dan helemaal blauw aan en heeft dan extra zuurstof nodig. Dan mogen wij de zuurstof ophogen, totdat zijn saturaties weer goed zijn en dan zetten we de stand weer op de afgesproken druk. Als hij over zijn toeren blijft en er niet uit lijkt te kunnen komen, geven we ook kalmeringstabletten.

We gaan kijken of we hem op een andere plek kunnen krijgen. Deze plek is te druk. Hij ligt nu zo dicht bij de telefoon en de deur waar iedereen maar in en uitloopt. Dat maakt hem onrustig, zodat hij zich opwindt en meer zuurstof nodig heeft. Het is wel een heel gedoe om hem te verplaatsen met al die apparaten en zo. Maar het is het wel waard.'

Gezien de moeite die het verpleegkundigen kost om een kind weer rustig te krijgen, proberen zij stressvolle situaties zo veel mogelijk te vermijden. Zij zijn niet gediend van arts-assistenten die het kind naar hun mening te lang onderzoeken of op een ongeschikt moment komen. Aan de couveuse van Dave hangt zelfs een bord met de tijden waarop hij wakker gemaakt mag worden. Alleen op die tijden mogen arts-assistenten hem onderzoeken. Maar niet iedereen houdt zich daar altijd aan. Een verpleegkundige uit het Northeastern General Hospital vertelt hierover:

'Waar ik zo boos om kan worden is het feit dat hier met grote letters een mededeling aan zijn bed hangt waarop de tijden staan. Maar niemand leest dat. Iedereen komt en gaat wanneer hij zin heeft. Zo krijgen die kinderen nooit rust. En als Dave iedere keer gewekt wordt duurt het weer uren voordat hij slaapt. Dan raakt hij steeds meer over zijn toeren, zodat de zuurstof weer omhoog moet omdat de saturaties dalen. Kinderen worden toch helemaal gestoord als ze om de vijf minuten gewekt worden.'

Evenals verpleegkundigen raken ook arts-assistenten het kind aan. Gezien het negatieve effect van veel interventies op een kind is snelheid en vaardigheid van handelen van groot belang. De mate waarin een staflid 'handvaardig' is werkt ook door in het prognosticeringsproces. Wanneer artsen een kind nog kunnen 'hanteren', geeft dit hen het gevoel dat ze nog grip op de situatie hebben en dat ze daarmee dus ook de toekomst van het kind nog in de hand hebben. Vaardige handen zijn dan ook een groot goed op de NICU. Eén van de arts-assistenten in het Northeastern geft in dit verband het volgende commentaar:

'Een NICU is een plek waar topspecialisten werken en de verpleging is zeer ervaren en zeer kundig. Dit maakt dat ze je bestaan als arts-assistent tot een hel kunnen maken. Ik heb geluk. Ik ben heel goed in handvaardige dingen, zoals het inbrengen van tubes en infusen. Daar is de verpleging door geïmponeerd, want hun eigen werk bestaat daar voor een groot deel uit: het werk met hart en handen en niet alleen met het hoofd. Als je binnen luttele minuten een tube in kunt brengen 
of een infuus binnen twee keer raak prikt, zit je hier op rozen. Zo niet dan ben je de klos. Dat zie je bij John (een andere arts-assistent JM). John mist de handvaardigheid. Hij telt nu de dagen en uren dat hij hier weg mag. Ze vertrouwen hem niet als arts en vertrouwen daarom hun kinderen liever niet aan hem toc. John raakt hierdoor $z 0$ onzeker en geblokkeerd dat hij daardoor helemaal niets meer kan."

Het aanraken van kinderen op de NICU vraagt ervaring en vaardigheid. Missen arts-assistenten deze handvaardigheid dan wordt de NICU voor hen een intensive 'scare' unit." Zij bevinden zich uiteraard in een leersituatie en de handelingen zijn voor hen dan ook tegelijkertijd oefensituaties. Het is echter niet altijd onervarenheid die hen parten speelt. Sommige kinderen laten zich moeilijk prikken. Anderen zijn zo vaak geprikt dat het lastig is een nog goede plek te vinden om een infuus te zetten. Voor artsen is dit niet alleen een bron van frustratic, maar ook van zorg. Zonder infuus hebben zij geen directe toegang tot de bloedbaan van het kind. In acute situaties missen zij dan de mogelijkheid om snel iets toe te dienen.

Het aanraken van kinderen vraagt naast vaardigheid ook moed. Ouders zijn vaak bang het kind pijn te doen of durven het kind nauwelijks aan te raken uit angst dat er iets mis gaat. Ze steken hun handen niet snel in de couveuse. Ook wanneer kinderen groter zijn en ze zelfs op schoot mogen, gaat deze angst niet direct weg. De ouders van Robert durven hem op basis van wat ze de dagen ervoor hebben gezien met geen vinger aan te raken, laat staan op schoot te nemen. Het vergt enige inspanning voordat de staf hen kan overtuigen dat Robert stabiel genoeg is om hun aanraking te verdragen. Als in de dagen daarna Robert enkele malen bij zijn moeder op schoot zit, raakt ook zij overtuigd van zijn goede conditie en krijgen zijn ouders hoop op een goede afloop.

De manieren waarop de betrokkenen zich rond de couveuse bewegen, resulteert in kennis die in het proces van prognosticeren een belangrijke rol speelt. De betrokkenen ontwikkelen deze kennis in verschillende mate op individuele wijze. Hierbij zijn vooral zintuiglijke ervaringen in het geding, zoals observatie en aanraking, terwijl ook de emotionele component - de spanning tussen betrokkenheid en distantie - van belang is.

\section{Prognostische bakens}

De situatie van een kind op de NICU is nooit statisch, maar voortdurend aan verandering onderhevig. Ook de gebeurtenissen die zich als gevolg van het behandelingstraject zelf voordoen, spelen door bij de bepaling van de prognose. De betrokkenen die meereizen over het traject doen door de tijd heen steeds nieuwe kennis en ervaring op. Dit gegeven vraagt om een verkenning van de 
grenzen van de ervaringsruimte en hoe die grenzen verschuiven. Er zijn verschillende referentiepunten die op de NICU worden gehanteerd om de prognose van een kind te bepalen. Door een beschrijving van de diverse referentiepunten en de wijze waarop ze functioneren in het prognosticeringsproces, komt de invloed van de dynamiek van de situatie zelf in beeld.

Ervaringen van de betrokkenen op de NICU wekken bepaalde verwachtingen. Ouders en stafleden zijn voortdurend op directe en indirecte wijze betrokken bij leerprocessen en daarbij speelt uiteraard ook de mate waarin verwachtingen worden gerealiseerd een voorname rol. De daaruit voortvloeiende kennis nemen ze mee in de bepaling van nieuwe verwachtingen. Ze kunnen bijvoorbeeld hun prognose in een bepaalde richting bijstellen. In het proces van prognosticeren worden verleden en toekomst in het heden aan elkaar geknoopt, en zo ontstaat een 'hedendaags verleden' en een 'tegenwoordige toekomst.' De toekomst krijgt betekenis in de reflectie op het verleden. Het geheel aan ervaringen uit het (recente) verleden genereert bepaalde verwachtingen over de toekomst van het kind, er tekent zich een 'verwachtingshorizon' af. ${ }^{2}$ De kennis en ervaring uit het verleden worden ingezet om de ontwikkelingen die zich voordoen op het traject te duiden en door te trekken naar de toekomst. Bij deze kennis spelen een aantal referentiepunten een belangrijke rol. Deze fungeren als het ware als 'prognostische bakens' op basis waarvan de betrokkenen de positie van het kind op het handelingstraject bepalen. Welke prognostische bakens staan de betrokkenen ter beschikking en op welke manier verkrijgen deze betekenis? Vier type bakens dienen zich aan: exemplarische kinderen, de technologische bepakking, ritme en tempo, en het gebruik van ruimte.

\section{Exemplarische kinderen}

In de productie van prognostische kennis vormen ervaringen met kinderen in overeenkomstige situaties een cruciaal baken. De situatie van een kind wordt door artsen vergeleken met die van kinderen die in de vakliteratuur beschreven staan. "Deze theoretische kinderen zijn aanleiding tot het vormen van categorieën van meer of minder kans, uitgedrukt in percentages. Het zijn deze anonieme lotgenoten met wie Tom zich moet meten als het gaat om de bepaling van zijn overlevingskansen. Op basis hiervan heeft hij bijvoorbeeld theoretisch gezien 'nog steeds een kans om van de beademing af te komen."

Persoonlijke ervaringen met kinderen in overeenkomstige situaties hebben dezelfde functie. Hierbij wordt niet zozeer een onbegrensd 'papieren' kader gehanteerd, maar de lokale geschiedenis van de afdeling. De verpleegkundigen bijvoorbeeld vergelijken Tom met andere kinderen die op de afdeling hebben gelegen. Eén van de verpleegkundigen vertelt in dit verband: 
We hebben hier eerder kinderen zoals Tom gehad. Op een gegeven moment weet je dan wel hoe laat het is. Zijn longen gaan kapot als gevolg van de beademing. Het is duidelijk dat hij nooit meer van de beademing af zal komen."

Deze praktische kennis ontstaat in de concrete zorg en behandeling van de kinderen. Het toekomstscenario dat deze verpleegkundige schetst komt niet zozeer voort uit zijn ervaring met Tom maar is eerder gebaseerd op het verloop van de ziektegeschiedenis bij andere kinderen: 'Ik ben bang dat we hier een tweede Mick aan het kweken zijn. Die kregen we uiteindelijk ook niet meer van de beademing af." 'Gewone' kinderen worden getransformeerd tot exemplarische kinderen en vervolgens gaan zij voor de betrokkenen als een prognostisch baken fungeren. Hierbij gaat het niet alleen om gangbare trajecten zoals die zich hebben vastgezet in de collectieve herinnering van de afdeling of het vakgebied. Ook het uitzonderlijke geval kan exemplarisch zijn. Stafleden trachten soms een sombere prognose van een collega om te buigen door te wijzen op dat ene kind dat het tegen alle verwachtingen in wel heeft gered. Waar de één wijst op de gebruikelijke afloop, brengt een ander juist de uitzondering op de regel in.

Prognostische bakens worden niet noodzakelijk door alle betrokkenen gedeeld. Niet iedereen heeft dezelfde kennis en ervaring. Voor de meeste ouders liggen op theorie en casuïstick gebaseerde bakens buiten het gezichtsveld. Evenmin zijn zij vertrouwd met het verleden van de afdeling en de gevallen die zich daar hebben voorgedaan. Hun prognostisch vermogen is niet gebaseerd op kennis die ontleend is aan de bibliotheek of het collectieve geheugen van de afdeling, maar komt primair voort uit hun dagelijkse bezoek aan de afdeling en hetgeen zich daar voordoet. Zoals al eerder over de ouders is opgemerkt, spelen de ontwikkelingen bij andere kinderen op de NICU een belangrijke rol in het prognosticeringsproces. Gaat het niet goed met hun eigen kind, dan kunnen andere kinderen op de afdeling als referentiepunt fungeren. Illustratief is het commentaar van de vader van Tom:

'Ze zijn tegenwoordig tot zo veel in staat. Neem bijvoorbeeld de baby die hier weken geleden een hartoperatie heeft ondergaan. We hoorde dat dat kind ten dode was opgeschreven. Nu is het al weer thuis. En ook nog gezond. Ze staan voor niets tegenwoordig. Dus waarom zouden ze niet iets voor Tom vinden. Je weet maar nooit.'

Toms vader zoekt hoop in de succesvolle afloop van de behandeling van Robert. De situatie van Tom geeft andere ouders daarentegen een gevoel van wanhoop: 'Als ik daar naar kijk denk ik soms: 'gaat het bij ons ook daar naartoe. Nee toch.' Voor deze moeder vertegenwoordigt Tom een toekomstbeeld waar ze niet aan durft te denken. Voor andere ouders is zijn situatie echter weer hoopgevend. Zij denken in termen van: 'Ons kind doet het zo slecht nog niet.' Niet 
de gezonde kinderen buiten, maar de andere neonaten op deze NICU fungeren hier als referentiekader voor de beoordeling van Tom.

Verwijzingen naar andere kinderen die worden ingezet in het prognosticeringsproces blijken divers van aard te zijn. Ze worden ontleend aan internationale vakliteratuur, hebben een lokaal karakter, zijn gebaseerd op persoonlijke herinneringen, of op ervaringen van anderen die via onderzoeksverslagen of anderszins openbaar zijn geworden. Sommige situaties hebben zich jaren geleden voorgedaan, terwijl andere nog geen week oud zijn. Deze verwijzingen naar uiteenlopende bakens reflecteren eveneens een bepaald historisch besef. De betrokkenen verhouden zich tot hun geschiedenis of toekomst op basis van twee verschillende repertoires. ${ }^{27}$ In een cyclisch repertoire heeft de loop der gebeurtenissen een vast patroon. Heden, verleden en toekomst zijn als het ware ingesloten onder een en dezelfde koepel van tijd. " $\mathrm{Zij}$ maken als vaste momenten deel uit van een natuurlijke kringloop waarin het verleden tevens het 'toekomstig heden' is. Deze cyclische structuur maakt de toekomst zowel voorspelbaar als onvermijdelijk. In uitspraken over Tom als 'een tweede Mick' fungeert het verleden bijvoorbeeld als een spiegel waaraan lessen kunnen worden ontleend. De prognose van een kind wordt zogezegd afgelezen aan het verleden: 'We hebben hier eerder kinderen zoals Tom gehad. Op een gegeven moment weet je dan wel hoe laat het is.' De verwijzing naar Mick impliceert de boodschap: 'zo ging het toen en zo zal het nu ook gaan. U bent gewaarschuwd!'

In het redeneerpatroon van een lineair repertoire geldt een andere conceptualisering van tijd. Redeneringen die louter en alleen naar het verleden wijzen zijn beperkt en passen niet in dit repertoire. In een lineair repertoire wordt wat in het verschiet ligt niet afgeleid uit de dictatuur van de natuurlijke orde, maar bestaat er een meer open karakter. Het lineair repertoire kent hierin twee versies. In een meer gematigde versie ligt de toekomst niet geheel open, maar is deze gebonden aan waarschijnlijkheid. De behandelend arts verwoordt de prognose van Tom achteraf bijvoorbeeld in termen van kansen: 'Tom had theoretisch gezien nog steeds een kans om van de beademing af te komen. Maar naarmate de tijd verstreek zou deze kans steeds kleiner worden.' Achter de verwachtingshorizon doemen nu verschillende mogelijkheden op, geordend naar mate van waarschijnlijkheid. ${ }^{19}$ De toekomst ligt niet vast, maar van een volledig open einde is ook geen sprake. Het aantal mogelijkheden is eindig en de waarschijnlijkheid dat ze zich voordoen is gerelateerd aan ervaringen uit het verleden. Ook een verwijzing naar kansen veronderstelt dat het verleden zich kan herhalen en dat het verleden de toekomst dus voorspelbaar maakt. Maar anders dan in het cyclisch repertoire wordt in het lineair repertoire de toekomst niet volledig gedicteerd door het verleden. Dit mag tot onzekerheid leiden, maar het biedt tevens ruimte voor de gedachte dat de toekomst maakbaar is, dat geschiedenis ook een kwestie van mensenwerk is. In de temporele structuur van dit his- 
torisch besef ligt een voorwaartse beweging besloten. In het lineaire repertoire gaat het niet over afzonderlijke momenten in een repetitief geheel, maar worden verleden, heden en toekomst gezien als opeenvolgende stadia in een ontwikkeling die gekenmerkt wordt door vooruitgang. Hierin hebben bijvoorbeeld statistische getallen geen eeuwigheidswaarde, maar een voorlopig karakter. Nieuwe kennis en ervaring zullen de kansen op herstel voor kinderen in de toekomst doen toenemen.

In het lineaire repertoire draagt de toekomst de belofte van verbetering in zich. Het is deze belofte waaraan de vader van Tom zich vastklampt: 'Ze staan voor niets tegenwoordig. Dus waarom zouden ze niet iets voor 'Tom vinden.' $\mathrm{Hij}$ beoordeelt de toekomst van zijn kind in het licht van de gebeurtenissen die zich om hem heen op de NICU voltrekken, de geslaagde hartoperatie van Robert in het bijzonder. Hij ziet in het heden reeds de belofte van de toekomst. De toekomst die Toms vader voor ogen heeft is er één waarin alles mogelijk en maakbaar is. Deze openheid gaat verder dan het principe van de waarschijnlijkheid toelaat. In het repertoire dat Toms vader hanteert laat de toekomst zich door geen enkele natuurlijke orde beperken, zij is transnaturaal. " Hier is de toekomst grenzeloos en gevuld met een schier oneindig potentieel. Deze volledige openheid kent geen enkele herhaling meer. $\mathrm{Zij}$ is irreversibel.

In het spanningsveld tussen ervaring en prognose kan de verhouding tussen heden, verleden en toekomst op verschillende wijze geconceptualiseerd worden. De aard van de conceptualisering van die verhouding laat meer dan wel minder ruimte voor menselijk ingrijpen, veel dan wel weinig ruimte voor zekerheid of verandering. Prognostische bakens krijgen dus mede betekenis door het temporele karakter van het repertoire waarin ze naar voren worden gebracht. Dit impliceert dat dezelfde bakens tot andere verwachtingen kunnen leiden. Zo is Mick in de gesloten verwachtingshorizon van het cyclisch repertoire bij uitstek een BPD-kind dat het zinloze karakter van Toms behandeling onderstreept. In de openheid van het lineaire repertoire heeft Mick daarentegen als exemplarisch voorbeeld een tijdelijk karakter en draagt hij juist bij tot hoopvolle verwachtingen over de toekomst van Tom. Zo geeft het temporele karakter van het repertoire (cyclisch of lineair) het spanningsveld waarin de prognose wordt gevormd een meer of een minder open karakter.

\section{De technologische bepakking}

Op de NICU overheerst het vooruitgangsdenken en het bijbehorende lineair repertoire." Stafleden leren ouders de opname van hun kind in lineaire termen te benoemen en de tekenen van voor- of achteruitgang binnen dat kader te herkennen." De technologische inbedding van het kind suggereert talloze markeringstekens. De vorm van beademing is bijvoorbeeld veelzeggend voor de 
conditie waarin het kind verkeert." Het is een goed teken als een kind steeds een lichte ademhalingsondersteuning nodig heeft. In zo'n geval wordt er wat extra zuurstof via het circulatiesysteem de couveuse ingebracht. Is het noodzakelijk dat deze zuurstof meer gericht moet worden ingebracht, dan wordt gebruik gemaakt van een koepeltje dat over het hoofd wordt geplaatst. Is dit onvoldoende en krijgt het kind te weinig zuurstof, dan wordt de zuurstof via een slangetje tot voor in de neus gebracht. Wanneer een kind meer ondersteuning nodig heeft, wordt de zuurstof met behulp van overdruk tot in de longen gevoerd. Ook bij deze CPAP* beademing ademt het kind nog steeds zelf. De beademing kan echter ook volledig door een beademingsapparaat worden overgenomen. Deze vorm wordt ingezet bij kinderen die te klein of te ziek zijn om zelf te ademen. Het apparaat brengt een mengsel van lucht en zuurstof tot in de luchtpijp. Het apparaat biedt de mogelijkheid om de druk, frequentie, hoeveelheid en zuurstofconcentratie van de beademing af te stemmen. Zowel de vorm van beademing als de stand van het apparaat wordt als belangrijke graadmeter voor de conditie van een kind beschouwd.

Een ander voorbeeld van een technologisch referentiepunt is het soort couveuse waarin het kind ligt. Er zijn gesloten couveuses, maar ook open couveuses. De couveuse is belangrijk voor zowel de warmtevoorziening als de preventie van infectiegevaar. Hele kleine kinderen liggen daarom in een gesloten couveuse. Naarmate ze groter worden zijn ze beter in staat om hun eigen lichaamswarmte te reguleren en volstaat een open couveuse. In veel van deze gevallen mogen ze dan ook naar de high care unit. Ook aan de hand van de voedingswijze wordt de toestand van een kind afgelezen. Een kind krijgt de voeding per infuus omdat het te klein is of omdat het te ziek is om zelf te zuigen. De overstap naar sonde of flesvoeding betekent dan ook een verbetering van de situatie van het kind.

De bovengenoemde referentiepunten markeren het verloop van de behandeling in termen van voor- of achteruitgang. Hiermee krijgt de ontwikkeling van het kind het karakter van een 'graduation' met bijbehorende feestelijkheden." Op veel NICU's hangen op de couveuses oorkonden met daarop leuzen als: 'Hoera, ik weeg 1000 gram, ik ben een kampioen'. Het belang van dergelijke afdelingsrituelen reikt verder dan een aardige geste in de richting van de ouders. Het expliceren van markeringsmomenten is belangrijk voor zowel ouders als staf." Met het gebruik van de graduationmetafoor worden echter bij ouders hoopvolle verwachtingen gewekt, die op een NICU geen stand houden." De graduationmetafoor kan bijdragen aan verwarring doordat ouders niet zijn voorbereid op het grillige ontwikkelingspatroon dat kinderen op de NICU vertonen. Een kleine terugval in de conditie van hun kind is voldoende om alle hoop weer weg te nemen. Dit is iets dat zich eerder voor zal doen in het Northeastern General Hospital dan in het Academisch Centrum omdat de kinderen in eerstgenoemde doorgaans veel kleiner en zieker zijn. Hierdoor is op deze 
NICU de vergelijking van een behandeling met een 'rollercoaster' meer op zijn plaats." Deze achtbaanmetafoor verbeeldt het grillige verloop van de opname beter omdat de ontwikkeling van een kind op deze afdeling eerder wordt gekenmerkt door de 'ups and downs' van instorten en herstellen. Bovendien suggereert de metafoor van de achtbaan tevens de angst die bij zo'n rit hoort."

De graduationmetafoor veronderstelt dat kinderen op de NICU zich langs een rechte lijn richting 'huis' begeven. De bijbehorende technologische bakens lijken op grond van deze lineaire structuur een vaste betekenis te krijgen: elk apparaat heeft altijd en overal dezelfde prognostische betekenis. In de praktijk hebben deze technologische bakens echter geen eenduidige betekenis. Sommige apparaten en hulpmiddelen worden in situaties van verschillende aard ingezet. Zo is het feit dat een kind in een open couveuse ligt per definitie niet een goed teken. Ook kinderen die instabiel zijn, worden in een open couveuse gelegd; dan heeft de staf er beter zicht op en kan er makkelijker snel worden ingegrepen. Aan de hoeveelheid technologische middelen die wordt ingezet kan evenmin een eenduidige conclusie worden verbonden. Kinderen met een erfelijke aandoening zoals trisomie $13^{*}$ of $18^{*}$ hebben in de periode dat ze op de NICU verblijven weinig apparatuur rond hun couveuse. Gezien het letale karakter van hun aandoening mag uit deze minimale instrumentele bagage geenszins een positieve prognose worden afgeleid.

Tijdens de behandeling is de betekenis van technologische bakens voor het proces van prognosticeren variabel. Hun prognostische waarde staat niet vast. In de behandeling van Esther staat bijvoorbeeld de eerste dag de beademing centraal. Maar nadat er bij haar een vierdegraads hersenbloeding is ontdekt, wordt de bepaling van haar prognose gedomineerd door de uitslagen van de echo's van het hoofd. Hiermee verliest de beademingstechnologie zijn centrale plaats in het prognosticeringsproces van de staf. Ook voor de ouders van Esther verschuift het beademingsapparaat naar de marge en komt de uitslag van de echo op de voorgrond te staan. Wanneer de betrokkenen echter aan dezelfde bakens verschillende waarden toekennen, gaan de prognostische ideeën over het kind sterk uiteen lopen. Voor bijvoorbeeld de ouders van Iris blijft de longfunctie het primaire baken op basis waarvan zij de toestand van hun kind inschatten. Net als Esther is Iris te vroeg geboren en krijgt zij na enkele dagen een ernstige hersenbloeding. De ouders is echter aan het begin van de opname verteld dat haar overlevingskansen vooral zouden samenhangen met de beademing. Een verpleegkundige in het Academisch Centrum zegt hierover:

'Je ziet het wel vaker gebeuren dat ouders alleen maar gefixeerd blijven op de longen. Dat is het enige dat voor hen telt als antwoord op de vraag of hun kind het overleeft. Dit is niet zo gek want we hebben hen zelf verteld hoe belangrijk de longfunctie is voor het kind om te kunnen overleven.' 
Voor de staf is in het geval van Iris de hersenbloeding die een paar dagen na haar geboorte geconstateerd wordt een belangrijk ijkpunt in het proces van prognosticeren. Haar ouders richten zich echter op de verbeterde longfunctie en zien dan ook de toekomst van hun kind zonnig tegemoet. De hersenbloeding speelt een veel geringere rol in hun beeldvorming over de prognose van hun kind. De vele gesprekken van de arts over de ernst van de hersenbeschadiging brengen daarin weinig of geen verandering.

Een prognostisch verschil tussen de betrokkenen ontstaat ook doordat er nieuwe ervaringen bijkomen. Waar artsen en verpleegkundigen terug kunnen vallen op hun reeds verworven theoretische en praktische kennis, staan ouders veelal met lege handen. Het enige kompas waarop zij in het begin varen is hetgeen de staf over hun kind vertelt. Wanneer stafleden ouders over de toestand van hun kind informeren, beperkt zich dit doorgaans niet tot de overdracht van gegevens. In begrijpelijke taal leggen zij uit aan ouders wat er aan de hand is, wat de therapie inhoudt of hoe een apparaat werkt. Informatieoverdracht gaat dus meestal hand in hand met expliciete kennisoverdracht. Daarnaast doen ouders gedurende de opname hun eigen ervaringen op en vinden zij ook langs deze weg bakens om de situatie van hun kind aan af te meten. Ouders die maandenlang de afdeling bezoeken, ontwikkelen hun eigen expertise op basis waarvan zij de situatic inschatten. Zo vertelt de vader van Tom:

We varen niet meer blind op wat artsen zeggen. In het begin doe je dat natuurlijk wel omdat je helemaal van niets weet. Maar je moet niet vergeten, ik sta hier ook al maanden naar die monitor te kijken. Je krijgt zelf ook een zekere ervaring en je neemt alles niet meer klakkeloos aan. We vinden het ook prettiger om met een ervaren verpleegkundige te praten dan alleen maar met de verpleegkundige die Tom die dag heeft verzorgd. We willen iemand met kennis van zaken.'

Er is sprake van cen voortdurende concurrentie tussen de diverse signalen en hun prognostische inhoud of betekenis. Soms verliezen technologische of andere bakens hun centrale positie en schuiven zij naar de marge. De prognostische bakens hebben voor de betrokkenen geen vaste waarde. Wat voor de één de allesbepalende indicator is, is mogelijk voor een ander reeds een gepasseerd station. Dergelijke verschuivingen kunnen uiteraard vooral bij ouders de nodige verwarring veroorzaken. Hebben ze eindelijk zicht op de gang van zaken en de dingen waar ze vooral op moeten letten, en dan blijkt deze moeizaam verworven kennis ineens niet meer geldig te zijn. 


\section{Ritme en tempo}

De prognose van het kind wordt ingeschat op basis van de wijze waarop het al dan niet in de pas loopt met het ritme en tempo van een tijdschema." In de neonatologiepraktijk komt tijd in vele soorten voor. Er is bijvoorbeeld klokkentijd, zoals die valt af te lezen van de centrale klok die op de unit hangt en die wordt gekenmerkt door continuĭteit, lineairiteit, regelmaat en meetbaarheid. Op de NICU vinden we ook taakgerichte tijd, die verbonden is aan de behandeling en zorg van een kind. Dit heeft bijvoorbeeld betrekking op medicatieschema's, een vierentwintiguurs infuus en controlerondes die om het uur of minder frequent plaatsvinden. Er zijn daarnaast roosters voor dag- en nachtdiensten, weekenddiensten, pauzes en bezoekuren en deadlines, zoals voor het aanleveren van voedings- en medicatiegegevens voor de apotheek. "Handelingen, apparaten en organisatorische principes brengen allemaal een eigen temporeel kader met zich mee, dat veelal een cyclisch karakter heeft. Omdat veel handelingen steeds opnieuw terugkomen, ontstaat er een zeker ritme. De temporele orde van het handelingsproces wordt voor een groot deel gedragen door deze ritmiek van de dagelijkse handelingen. Het leven op de NICU zit ingesponnen in een web van temporele relaties waarin verschillende noties van tijd samenvallen. "Deze temporele structuren staan niet los van elkaar maar hangen nauw met elkaar samen. Handelingen grijpen op elkaar in, volgen elkaar op of vinden gelijktijdig plaats, zoals het schema van de medicatietijd en dat van de controlerondes. Ze kunnen elkaar ook uitsluiten, zoals een dagdienst en een nachtdienst dat doen. Voe-

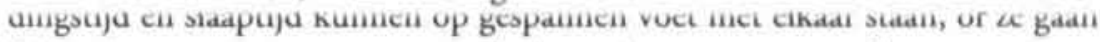
juist prima samen wanneer er sprake is van intraveneuze voeding.

Naast aspecten die te maken hebben met ritme en timing, kent het leven op de NICU ook een eigen tempo, dat doorgaans hoog is, zowel ten aanzien van de werkzaamheden als de doorstroom van kinderen. In het Northeastern General Hospital wordt een kind bij de geringste twijfel over mogelijke complicaties na de geboorte direct overgebracht naar de NICU. In veel gevallen blijkt er sprake te zijn van vals alarm en kan het kind al na enkele uren de afdeling weer verlaten. Deze 'pitstops' brengen een enorme bedrijvigheid met zich mee. Maar zelfs als een kind wel langer op de NICU blijft, duurt dit verblijf gemiddeld niet langer dan drie weken. De snelle doorstroom van opnames brengt een temporeel regime met zich mee waarin de kinderen worden verzorgd en behandeld. Het temporele regime werkt door in het prognosticeringsproces. De situatie van een kind kan op verschillende manieren met dit regime botsen.

In de eerste plaats, brengen de kinderen op de NICU een eigen temporaliteit in. ${ }^{*} \mathrm{Zij}$ claimen als het ware een eigen procesgerichte tijd: de tijd die verpleegkundigen nodig hebben om hen te verzorgen. "Deze procesgerichte tijd is van toepassing op de individuele zorg en behandeling en wordt primair bepaald 
door de behoefte van het kind. "Het ene kind vraagt bijvoorbeeld meer tijd met sondevoeding of flesvoeding dan een ander kind. Maar het natuurlijke tempo van een kind kan een andere zijn dan het functionele tempo van de organisatie. In samenhang met andere temporele structuren kan procesgerichte tijd een normatieve lading krijgen, in de zin van een tweedeling van de populatie van de NICU in 'makkelijke' en 'moeilijke' kinderen. Kinderen uir de tweede categorie vergen bij hun verzorging meer dan de gebruikelijke hoeveelheid tijd en zij vormen bovendien een constante bedreiging voor de heersende orde, het ritme van de dagelijkse gang van zaken. De procesgerichte tijd kan een rol gaan spelen in de bepaling van de prognose bij kinderen die uit de pas gaan lopen. Een kind kan bijvoorbeeld opeens veel slechter gaan drinken; kon het voorheen makkelijk de sondevoeding verdragen of de fles achter elkaar leegdrinken, nu vraagt het veel tijd om dezelfde hoeveelheid binnen te krijgen. Zeker als zo'n proces alleen maar meer tijd gaat kosten, gaat men zich zorgen maken. Afwijkingen van het patroon leiden tot nieuwe inschartingen van de situatie.

In de tweede plaats bezitten aandoeningen een eigen temporeel kader. $\mathrm{Ze}$ behoren op een bepaald moment over te zijn. Ook zijn er meer en minder risicovolle momenten. De eerste drie levensweken na de geboorte van een prematuur kind kennen bijvoorbeeld hun eigen risico's. Voor een tevroeggeborene is de kans op overlijden het grootst gedurende die drie weken. Artsen durven dan ook in de eerste instantie nauwelijks over een tijdsgrens heen te kijken. Eerst moet het kind de eerste twee dagen doorkomen. Tijd fungeert hier duidelijk als een prognostisch baken. Overleeft een kind deze eerste twee dagen, dan schept dat bepaalde verwachtingen voor de toekomst. Het kind heeft immers bewezen over een zekere vitaliteit te beschikken."

In de derde plaats hebben behandelingen eveneens een tijdschema. Het kind wordt geacht het behandelingstraject in een bepaald tempo af te leggen. Veel kinderen passen in dit ritme van de NICU en zijn na enkele weken weer uit het zicht verdwenen; ze zijn thuis of op een andere afdeling. Sommige kinderen lopen voor op hun behandelingsschema. Een enkeling raakt achterop en lijkt op een gegeven moment helemaal niet meer vooruit te komen. 'Wij zijn hier niet gewend om met chronische baby's om te gaan. Op de IC is alles kortdurend. Een kind dat hier maanden ligt, dat zijn we niet gewend te begeleiden', merkt een verpleegkundige uit het Academisch Centrum op. Naarmate een kind langer dan gebruikelijk op de afdeling verblijft, lijkt het steeds minder vooruit te komen en verdwijnt ook de hoop op een goede afloop. Een langzame ontwikkeling botst met het gebruikelijke tijdschema van behandeling en herstel, mede omdat dan de bijbehorende voldoening uitblijft. Een langdurige opname plaatst kinderen in de categorie 'chronische gevallen'. Het zijn de 'problematische behandelingen'. Een kind dat bijvoorbeeld lang aan de kunstmatige beademing ligt, ontwikkelt $\mathrm{BPD}^{*}$ en naarmate de tijd vordert, wordt de prognose somberder. Tom is zo'n geval. 


\section{Het gebruik van ruimte}

Naast tijd biedt ook ruimte concrete bakens die bij de bepaling van een prognose worden ingezet. In het voorafgaande heb ik in dit verband al het belang van de bewegingscoördinaten van de betrokkenen besproken. De bewegingen van stafleden en ouders rond de couveuse werken echter niet alleen door op hun eigen prognosticering. Hun bewegingscoördinaten kunnen voor anderen een indicatie van de toestand van het kind zijn. Het veelvuldig heen en weer lopen van een verpleegkundige naar het alarm van een kind is bijvoorbeeld voor een arts een teken dat het kind instabiel is. Ook ouders vatten de bewegingen van de staf op als indicatie van de toestand van hun kind. Bij een kind in een uiterst instabiele conditie is ook de arts de hele dag naast de couveuse te vinden. De frequente aanwezigheid van een arts bij de couveuse zegt iets over de conditic van het kind. 'Vaak' en 'dichtbij' zijn in dit geval geen goed teken. Ouders weten dat, zoals blijkt uit het commentaar van de vader van Robert:

'Vannacht heb ik iets kunnen slapen, maar de eerste nacht was verschrikkelijk. Ik kon niet slapen. Als ik op was en ik ging even op de afdeling kijken en zag iedereen bij Robert staan, dan dacht ik meteen dat er iets ergs gebeurd was. Zag ik alleen een zuster bij hem staan, dan was ik bang dat er iets ergs zou gebeuren en dan zou er niemand zijn. Zo zit ik de hele tijd in spanning.'

Op het eerste gezicht lijkt de directe nabijheid van stafleden rond de couveuse een indicatie voor een slechte prognose. Maar dit is soms schijn. Hoewel de conditie van Robert alle aandacht van de staf opeist, blijken zijn vooruitzichten goed. Tom moet het zonder deze aandacht stellen, al is het uitzicht op een goede afronding van zijn behandeling aanmerkelijk minder rooskleurig. Maar de conditie van Tom is, in tegenstelling tot die van Robert, wel stabiel. Hoe slecht zijn toestand ook is, hij bevindt zich niet in een kritische fase. Deze stabiliteit betekent dat hij minder aandacht van de arts krijgt. De tijd dat een arts aan een kind besteedt is een verdelingsvraagstuk. De arts is daar waar zijn of haar aanwezigheid noodzakelijk is. Verpleegkundigen in zowel het Academisch Centrum als het Northeastern geven aan dat ze soms het gevoel hebben dat een chronisch kind er maar een beetje 'bijhangt'. Een verpleegkundige in het Northeastern:

' $\mathrm{Ze}$ (artsen JM) denken dat ze alles al weten. Dat merk je tijdens de visites. Het begint altijd met : "Dit is Dave, ons welbekend" en vervolgens wordt het verhaal afgeraffeld en wandelt iedereen weer verder. Chronische kinderen zoals Dave krijgen relatief weinig aandacht. Men kent ze te goed, zodat men niet meer echt kijkt.'

Ook locaties worden geduid in termen van vooruitzichten. Een uitnodiging van een arts voor een gesprek in de ouderkamer wordt door veel ouders als een 
slecht teken gezien. Goede berichten krijgen ze meestal bij de couveuse te horen. Slechte berichten gaan meestal gepaard met afzondering in de ouderkamer. Ouders zien hoe anderen met een bedrukt gezicht deze kamer verlaten. Dat is het beeld dat blijft hangen.

Naast deze concrete bewegingen van de betrokkenen op de NICU kent de ruimte waarin zij de prognose van een kind definiëren ook een meer algemene geografische dimensie. Zo conceptualiseren ouders gedurende de opname van hun kind locaties veelal in termen van afstand. Thuis zijn betekent 'ver weg zijn', 'niet bij het kind zijn' en de parkeerplaats van het ziekenhuis is 'er bijna zijn' of 'er weer vandaan gaan'. De geografische werkelijkheid waarin artsen zich bewegen is er daarentegen één die wordt bepaald door hun taak en verantwoordelijkheid. De artsen houden zich bezig met de bepaling en uitvoering van de behandeling. De mogelijkheden hiervoor beperken zich niet tot de eigen NICU; er wordt bijvoorbeeld ook een beroep gedaan op andere NICU's in het land of zelfs daarbuiten. Voor een neonatoloog is 'ver weg' dat wat niet binnen enkele uren per babylance of helikopter te bereiken is. 'Dichtbij' is dan ook niet alleen de radioloog op de derde verdieping, maar ook bijvoorbeeld een NICU in een ander ziekenhuis. De wijze waarop deze geografische werkelijkheid doorwerkt op het prognosticeringsproces wordt zichtbaar in de bespreking over Anne.

\section{Academisch Centrum}

In de vergaderkamer van de afdeling zitten twee neonatologen, een kindercardioloog en drie verpleegkundigen. Onderwerp van gesprek is de slechte conditie van Anne als gevolg van haar harţnroblemen. De attending beschrijif de toestand waar Anne zich in bevindt. Een hartoperatie lijkt de enige oplossing, maar het kind is nog te klein voor een dergelijke hartoperatie.

De kindercardioloog: 'Dat kan pas over anderhalf jaar. En anderhalf jaar is erg lang voor een kind dat elke dag dat ze leeft, moet vechten om de volgende dag te halen. Daarnaast is er de mogelijkheid van een harttransplantatic. Daar is leeftijd geen beletsel. Alleen wordt dat in dit ziekenhuis niet gedaan. Maar wel in Parijs." Met de suggestie van een harttransplantatic heeft de cardioloog een nieuw traject op tafel gelegd. Het hele gesprek zwaait om richting transplantatie. Opeens is Anne cen transplantatiekind. Er wordt enthousiast gereageerd. Parijs is immers maar een paar uur vliegen. De cardioloog relativeert zijn voorstel door te wijzen op de mogelijkheid van een lange wachtlijst en de hoge kosten die niet door de verzekering worden vergoed. Afgesproken wordt dat hij eerst inlichtingen zal inwinnen en dat afhankelijk daarvan deze mogelijkheid met de ouders van Anne besproken zal worden.

In deze situatie overheerst het gebruik van een situationeel repertoire: de situatie van Anne staat centraal. Waar het mij echter in dit geval om gaat, is dat in deze discussie de grenzen van haar situatie zo ver mogelijk worden verlegd. Dit 
gebeurt door de buitenwereld naar binnen te halen. "Doordat de kindercardioloog de Franse transplantaticafdeling tot onderdeel van de situatie maakt, neemt voor Anne de kans op overleving toe. Alsof er onverwachts een deur naar de toekomst wordt geopend. De prognose van Anne ziet er heel even veel beter uit. Ze verandert van een hopeloos geval in een potentieel transplantatiekind en de prognostische aandacht verschuift naar de vraag of de organisatie van een transplantatic in het buitenland mogelijk is. Om de buitenwereld binnen bereik te krijgen is in dit geval enkel een abstracte verplaatsing onvoldoende. Ook het kind zelf moet verplaatst worden, en wel in de tegenovergestelde richting: naar buiten. Over de haalbaarheid van het laatste bestaat echter sterke twijfel bij de gesprekspartners.

De buitenwereld is een vaste component van de geografische werkelijkheid waarin een neonatoloog opereert. Hierbij gaat het zeker niet alleen over exclusieve behandelingsmogelijkheden elders. De buitenwereld speelt een belangrijke rol in de dagelijkse praktijk van een neonatoloog. Het is de plaats waar kinderen vandaan komen en als het goed is weer naar terugkeren. Via deze voortdurende in- en uitstroom van kinderen blijft de NICU met de wereld verbonden. De neonatoloog is verantwoordelijk voor zowel het opname- als ontslagbeleid. Deze taak betekent in de praktijk dat de arts zich op de hoogte houdt van bijvoorbeeld de gebeurtenissen in de verloskamer, de opnamecapaciteit van andere NICU's en (terug)plaatsingsmogelijkheden in perifere ziekenhuizen. Idealiter moet er altijd een plaats open zijn voor een nieuwe opname, want de mogelijkheid van een snelle opname verbetert de prognose van het kind aanzienlijk. In het Northeastern is een nieuwe opname soms een kwestie van alles even opschuiven. Hier is alle apparatuur verplaatsbaar en in het ergste geval worden de couveuses tijdelijk op de gang gezer. In het geografisch besef van de neonatoloog die hier werkt, is ruimte elastischer. Voor zijn collega in het Academisch Centrum is ruimte een minder plooibaar begrip. Hier is het aantal plaatsen letterlijk gefixeerd en houden de neonatologen zich via een dagelijks bijgewerkt computerprogramma op de hoogte van de beschikbare plaatsen op de andere NICU's in het land. Deze units maken in feite ook deel uit van de geografische werkelijkheid van de neonatoloog in het Academisch Centrum.

Anders dan voor een neonatoloog beperkt de geografische werkelijkheid voor verpleegkundigen zich meer tot de afdeling zelf. Dit is geen kwestie van een beperkte blik, maar komt voort uit de specificiteit van hun taakstelling. Verpleegkundigen zorgen voor het kind, waken over de toestand en voeren een groot deel van de behandeling en diagnostische testen uit. Voor deze verantwoordelijkheid zijn mensen en middelen buiten de muren van de afdeling veel minder relevant. De hoogte van de monitor, de bewegingsruimte tussen twee couveuses, de afstand van de tafel naar de knop van het alarm op de monitor - al deze zaken maken deel uit van het ruimtelijk besef van verpleegkundigen. De 
fysieke opstelling van de afdeling krijgt betekenis in het licht van het dagelijks gebruik. Als 'ver weg' geldt hier de buizenpost op de gang of het lab op de andere etage waar de laatste test nog snel naartoe moet worden gebracht. 'Dichtbij' is de apparatuur waar je niet aan mag komen omdat er een niet-reanimatie beleid is afgesproken. In dit concrete gebruik krijgt voor verpleegkundigen de geografische dimensie van de NICU gestalte. Zo biedt ruimte op uiteenlopende wijze bakens in het prognosticeringsproces.

\section{Ervaring en verwachting}

De bepaling van een prognose van een kind op de NICU blijkt aldus nauw verweven met talloze factoren. Om te beginnen doen sociale rollen ertoe: verschil in sociale positie leidt tot uiteenlopende prognostische kennis. Maar deze typering is niet uitputtend. Er komt nog iets bij: de prognose komt ook tot stand in de wijze waarop eenieder zich met her kind bezighoudt, de reeds bestaande kennis, de ervaringen die men opdoet tijdens de behandeling in de directe confrontatie met het kind en in de interactie tussen de betrokkenen. De omgang met het kind en met elkaar laat zich niet beschrijven in enkel een opsomming van gegeven taken en officiële verantwoordelijkheden. Een analyse die de sociale positic als uitgangspunt neemt, biedt - anders gezegd - geen ruimte voor de rol van de omstandigheden, de geschiedenis van de afdeling en de kennis en ervaring van de betrokkenen in het prognosticeringsproces. Omgangsvormen als analytische ingang maakt een ontsnapping mogelijk uit het keurslijf van de sociale groep, zonder het belang van de sociale positie en de bijbehorende taken te negeren. Onderzoek naar de verschillende 'omgangsvormen' haalt andere elementen van het prognosticeringsproces naar voren, zoals tactiele kennis, concrete bewegingscoördinaten en emoties. Het is de situatie van waaruit men op de behandeling betrokken is en die mede bepalend is voor de definiëring van de prognose.

Naast aandacht voor eenieders omgang met het kind biedt een analyse van ervaring ook de mogelijkheid om de rol van de factor 'tijd' in beschouwing te nemen. Een prognose komt tot stand terwijl men een traject aflegt. Gedurende dit proces verandert de ervaring die de betrokkenen hebben. De diversiteit van de opgedane kennis en ervaring leidt ertoe dat de betrokkenen verschillende referentiepunten als baken gebruiken en/of overeenkomstige referentiepunten op uiteenlopende wijze van betekenis voorzien. Kinderen, apparaten en de temporele of ruimtelijke orde hebben geen vaste prognostische lading. Wat zich als referentiepunt aandient en welke betekenis hieraan wordt gegeven, hangt samen met de ervaring die de betrokkenen hebben opgedaan. Prognoses worden gevormd op basis van een individueel geconstrueerd raamwerk, de eigen ervaringsruimte, ieders specifieke bemoeienis met het kind. Prognostische 
kennis ligt als het ware verankerd in eenieders ervaringsruimte en maakt uiteenlopende verwachtingen over wat zich achter de horizon aandient begrijpelijk.

De handelingstrajecten die de betrokkenen voor ogen hebben staan soms op gespannen voet met elkaar. De fricties die hieruit voortvloeien, kunnen het handelingsproces verlammen. En dan zijn strategieèn noodzakelijk, die het proces weer vlot kunnen trekken. Er moet immers gehandeld worden. In voorgaande hoofdstukken kwamen al enkele corrigerende vormen aan de orde, zoals diplomatie en een institutionele orde van gezamenlijkheid in de vorm van een team. In het volgende hoofdstuk wil ik op een bepaald soort spanning dieper ingaan, namelijk de morele dilemma's verbonden aan het handelen op de NICU en de wijze waarop deze worden opgelost. 



\section{De morele lading}

\section{Academisch Centrum}

Vrijdag: Er wordt bij Tom een EEG gemaakt. De ventrikels in zijn hoofd blijken sterk vergroot. Dit duidt op een drukverhoging als gevolg van vochtophoping. Er zal een interne drain geplaatst moeten worden om het vocht af te voeren.

Woensdag: $\mathrm{Na}$ de ingreep van zaterdag is Tom zienderogen achteruit gegaan. De beademingsdruk staat nog steeds op achtendertig. Zijn bloedwaarden laten op geen enkele manier toe dat de beademing wordt afgebouwd.

Toms vader is al enkele dagen niet meer geweest. Hij kan het niet langer aanzien en blijft thuis. Hij is zich al aan het terugtrekken, omdat hij weet dat hij binnenkort zijn zoon zal verliezen. In de dagelijkse gesprekken tussen hem en zijn vrouw keert dit besef steeds terug.

Donderdag: De interne drain leidt tot complicaties bij Tom. Hij verliest nu zoveel vocht dat er een onderdruk ontstaat die zo groot is dat zijn schedelnaden over elkaar heen vallen. Naarmate de dag vordert, verslechterd zijn conditie.

Tijdens de visite staat in de discussie over Tom de onderdruk in het hoofd centraal. Desondanks besluiten de artsen hun beleid te handhaven. $\mathrm{Ze}$ achten het risico op een hersenbeschadiging te groot om de drain te verwijderen. Het probleem van de onderdruk kan met behulp van medicijnen verholpen worden. Ook moet zijn couveuse omhoog gekanteld worden. Twee verpleegkundigen wijzigen de stand van Toms couveuse, maar het gaat niet van harte. 'Intriest allemaal', mompelt de één tegen de ander.

12.00 uur: Tom ziet er weer wat beter uit. Zijn fontanellen hebben weer hun normale vorm teruggekregen. De onderdruk in zijn hoofd lijkt verdwenen te zijn.

Vrijdag: Het gaat slecht met Tom. Hij verzuurt helemaal. De behandeling moet opnieuw worden bijgesteld.

Maandag: De drain in zijn hoofd blijkt wat te lekken, maar niet ernstig naar het schijnt. Sinds de drukverhoging in zijn hoofd gaat het niet goed met hem. De beademingsdruk is dit weekend opnieuw teruggezet naar de vorige stand. Hiermee is het afbouwen van de beademing opnieuw mislukt.

Woensdag: Tom heeft nierstenen. Als gevolg van de vochtuitdrijvende middelen worden de nieren iedere keer zo sterk 'leeg geknepen' dat het calciumgehalte in 
de nieren sterk stijgt en er zich nierstenen kunnen vormen. Daarnaast is er een toename van de druk in zijn hart geconstateerd. Als gevolg van de corticosteroïden is de ventrikelwand verdikt. Hierdoor is het uitstroomgebied bij elke slag vernauwd zodat de doorstroom naar de aorta is verminderd.

Als Tom vijf maanden oud is, wordt zijn behandeling geteisterd door een reeks van problemen die elkaar in rap tempo opvolgen. Bij de ouders van Tom is de hoop op herstel min of meer verdwenen. Ook de artsen zijn nu somber over de kans dat Tom ooit zonder kunstmatige beademing kan leven. Waar in de voorgaande periode elk probleem op zich werd beschouwd, dringt zich nu het volledige beeld op. Steeds vaker komt de vraag op of voortzetting van de behandeling bij dit kind nog wel zinvol is. Wat moeten ze doen? Doorgaan of stoppen? Aan beide handelingsopties kleven grote bezwaren. Door te stoppen lopen ze het risico hem zijn laatste kans op herstel te ontnemen. Doorgaan impliceert het risico dat hun inspanningen enkel bijdragen aan uitzichtoos lijden.

Wanneer er twee opties zijn waaruit moeilijk een keuze valt te maken, staat de praktische orde van de afdeling onder druk. Dit hoofdstuk concentreert zich op de vraag hoe men deze spanning tracht te reduceren en zo de praktische orde op de afdeling tracht te handhaven of te herstellen. In dit verband richt ik mij op situaties die expliciet over levensbeëindigend handelen gaan. Dergelijke keuzes beperken zich niet tot het staken of voortzetten van een behandeling. In sommige gevallen staat de praktische orde al onder druk voordat het kind is geboren. Hierbij gaat het dan om de vraag of er na de geboorte met een behandeling gestart moet worden; de discussie in de verloskamer voor de geboorte van Esther ging hierover. Hier worstelde de betrokken stafleden met een morele beslissing: een beslissing waarvan men denkt dat deze van invloed is op de kwaliteit van het leven van het kind en/of de ouders. Voor een analyse van de wijze waarop betrokkenen met morele vraagstukken omgaan, dienen verschillende vragen als leidraad: hoe kan het proces waarin de uiteindelijke keuze totstandkomt, worden geduid? Waar liggen de morele grenzen van de praktijk waarin deze kinderen worden behandeld? Op welke manier gaan de betrokkenen vervolgens met het genomen besluit om? Welke consequenties heeft de beslissing om met een behandeling te stoppen? Wie dragen de verantwoordelijkheid, of hoe is die verantwoordelijkheid verdeeld? Alvorens nader op deze vragen in te gaan, wil ik eerst het problematisch karakter van beslissingen over levensbeëindigend handelen ter discussie stellen aan de hand van het besluitvormingsproces over Esther in zowel de verloskamer als in de stafvergadering.' Hoewel beide situaties ook in het tweede en derde hoofdstuk onderwerp van analyse zijn geweest, ga ik in dit hoofdstuk expliciet in op de morele dimensie van beslissingen omtrent levensbečindigend handelen. Aan het einde kom ik terug op de behandeling van Tom en de daaraan gekoppelde morele aspecten. 


\section{De aard van de beslissing}

Het feit dat Esther zowel prematuur als dismatuur is en met een falende hartactie kampt, geeft de aanwezigen in de verloskamer onvoldoende houvast om de situatie na de geboorte goed te kunnen inschatten. Er is een kans dat het kind na de geboorte zal blijven leven, al zijn ernstige handicaps dan niet uitgesloten. Er bestaat ook een gerede kans dat het kind direct na de geboorte komt te overlijden. Moet er wel of niet worden ingegrepen na de geboorte? De keuze om van iedere behandeling af te zien zou impliceren dat het kind overlijdt. Vanuit dit perspectief gezien gaat de keuze in de verloskamer over al dan niet levensbeëindigend handelen.

De complexiteit van beslissingen omtrent levensbeeindigend handelen leidde in de jaren tachtig tot een uitgebreid debat in Nederland. 'Het debat resulteerde in een aantal richtlijnen.' Richtlijnen in de vorm van beoordelingsschema's en besluitvormingsprocedures zouden de arts op de werkvloer moeten steunen en sturen,

Zowel de CAL-nota van de KNMG als het rapport Doen of Laten? van de Nederlandse Vereniging voor Kindergeneeskunde (NVK) geven richtlijnen voor beslissingen over levensbeèindigend handelen. Volgens het rapport Doen of Laten? is behandeling zinloos bij kinderen die medisch gezien kansloos zijn of als behandeling louter bijdraagt aan een onleefbaar leven.' Het rapport formuleert criteria op basis waarvan de arts een van de drie voorgestelde handelingstrajecten kiest.

De eerste optie is de keuze voor het starten van een behandeling met gebruik van alle ten dienste staande middelen (traject A). Deze keuzemogelijkheid is te verkiezen als het kind in de eerste categorie valt. Dat is

'(...) overal waar de levenskans, respectievelijk de kans op een leefbaar leven vooralsnog zo groot wordt geacht, dat dit belang opweegt tegen de schade en het lijden die het gevolg van de medische behandeling kunnen zijn. Dit is reden om de patiënt het voordeel van de twijfel te geven. (...) Maar wie begint dient van meet af an duidelijkheid te verschaffen, dat het weer staken van de levensverlengende handelingen alsnog tot de mogelijkheden behoort. (...) De afweging die men moet maken is: hoeveel lijden, hoeveel onzekerheid, staat tegenover welke kans dat de prognose toch aanvaardbaar is en de behandeling kind en gezin dus ten goede komt."

Als tweede mogelijkheid wordt een proeffase met beperkte inzet van middelen genoemd (traject B). Bijvoorbeeld een primair goede opvang, zuurstof, warmte, infuus. Dit geldt voor kinderen die in de tweede categorie vallen. Dit zijn kinderen waar twijfel over de zin van interventie bestaat. Een keuze voor dit traject kan ertoe bijdragen dat 
'(...) in twijfelgevallen een selectic ontstaat tussen levenskrachtige kinderen met een redelijk goede prognose die met intensieve zorg gediend zijn, versus kinderen die daar niet mee gediend zijn en beter af zijn met zorg voor een menswaardige dood. ${ }^{\text {. }}$

Als derde mogelijkheid wordt primair abstineren genoemd (traject C). Hiervoor kan gekozen worden wanneer kinderen in de derde categorie vallen. Dit is het geval

'(...) indien er redelijke zekerheid omtrent de diagnose bestaat en van daaruit een uiterst sombere prognose gesteld moet worden (bijvoorbeeld anencefalie", andere prenataal reeds gediagnosticeerde ernstige afwijkingen of extreme prematuria, vooral in combinatie met ernstige perinatale asfyxie*), zal op het moment van de geboorte met name bij vitaal bedreigde kinderen slechts één weg openstaan: stervensbegeleiding. Hierover bestaat een communis opinio."

In het schimmige gebied rond beslissingen over levensbeëindigend handelen kunnen helder omschreven criteria als leidraad fungeren. Hiermee heeft iedereen die zich voor een dergelijke keus gesteld ziet een instrument in handen om een besluit te nemen. Met deze richtlijnen krijgt de neonatologiepraktijk een handvat aangereikt waarmee de complexiteit van beslissingen over levensbeëindigend handelen gereduceerd en gereguleerd kan worden.

Gezien de onzekerheid waar de aanwezigen in de verloskamer mee worstelen, lijken de richtlijnen van het NVK-rapport een hulpmiddel bij uitstek. Zij zijn immers voor dit soort situaties ontworpen. Toch makt men in het besluitvormingsproces over de behandeling van Esther geen gebruik van deze richtlijnen, omdat deze een andere problematiek en praktijk veronderstellen dan die waar de betrokkenen in de verloskamer mee te maken hebben.' Welke vooronderstellingen over de problematiek met betrekking tot levensbeëindigend handelen liggen ten grondslag aan de richtlijnen? Op welke wijze verhouden deze zich tot die waar de betrokkenen in de verloskamer rond Esthers bevalling tegenaan lopen?

\section{Evidentie}

Het rapport poogt een antwoord te geven op de vraag: moeten we wel of niet ingrijpen? De arts stapt op handelingstraject $A$ als het kind in categorie 1 valt, kiest voor traject B bij kinderen uit categorie 2 en voor $\mathrm{C}$ bij kinderen in de categorie 3. De keuze tussen doen of laten is op deze manier teruggebracht tot een kwestie van het kind categoriseren door feiten te interpreteren en kansen af te lezen.'

Het probleem ligt echter juist in de categorisering van het kind. Hoe duidelijk de richtlijnen ook aangeven in welke situatie levensverlening of levensbeèindiging gerechrvaardigd is, het blijft aan de betrokkenen om te bepalen of 
er daadwerkelijk van zo'n toestand sprake is. Wat is de toestand van Esther? Zijn haar kansen 'vooralsnog zo groot' dat zij opwegen tegen de nadelige effecten van medisch ingrijpen? Of behoort dir kind tot de groep 'twijfelgevallen' en valt zij in de tweede categorie? Hoe groot moet hun zekerheid zijn willen zij 'redelijk' genoeg zijn om een primair abstinerend beleid te rechtvaardigen? De grenzen tussen de categorieën zijn vaag. Esther kan in elk van de dric prognostische categorieèn ondergebracht worden. Het rapport verwijst bovendien naar criteria als professionele ervaring en statistische gegevens omtrent overlevingskansen en de beoordeling van toekomstig lijden, zelfredzaamheid, afhankelijkheid en mogelijkheden tot communicatie." Maar ook met deze verdere verwijzing zijn de artsen in de verloskamer niet geholpen. Het instrument dat hen wordt aangereikt doet precies een beroep op hetgeen waarop zij nog nauwelijks zicht hebben, namelijk de prognose van dit nog ongeboren kind. Op deze manier lijken de richtlijnen eerder een herformulering van het probleem dan een hulpmiddel om tot een beslissing te komen. De richtlijnen die men op de afdeling krijgt aangereikt om een morele orde aan te brengen, veronderstellen een transparante, homogene praktijk." Een praktijk waarin de feiten evident zijn en binnen handbereik liggen.

In de richtiijnen vormen de feiten het vertrekpunt van de besluitvorming. Voor de aanwezigen in de verloskamer ligt dit vertrekpunt echter in een domein dat zich buiten hun bereik bevindt. Het problematisch karakter van de keuze tussen doen of laten schuilt precies in de onmogelijkheid om Esther te categoriseren. Het is juist het gemis aan duidelijkheid over de situatie die de besluitvorming in de verloskamer compliceert. Daar overheerst niet de vraag wat er gedaan moet worden, maar wat er aan de hand is. De onzekerheid in de verloskamer ten aanzien van het behandelingsbeleid, laat zich dan ook niet oplossen met deze richtlijnen. $\mathrm{Zij}$ geven alleen richting aan handelen als duidelijk is wat feitelijk het geval is. Juist op het moment dat de aanwezigen in de verloskamer nauwelijks iets in handen hebben om hun keuze op te baseren, moeten zij een beslissing nemen. Er wordt dan ook gezocht naar een alternatief dat wel uitkomst kan bieden en het handelingsproces weer vlot kan trekken: het woord is aan de ouders.

Net als stafleden gebruiken ook ouders repertoires. De moeder van Esther hanteert in haar beslissing over Esthers een situationeel repertoire. $\mathrm{Zij}$ is daarbij niet zozeer gericht op de situatie van het kind na de geboorte, maar juist op de situatie van het kind op dat moment, namelijk haar aanwezigheid in haar buik. De hartfrequentie op de monitor van het CTG-apparaat maakt duidelijk dat het kind elk moment kan overlijden. De mogelijkheid dat het kind in haar buik zal overlijden is voor de moeder onverdraaglijk. Bevangen door angst zoekt zij een uitweg en vindt deze in de sectio ${ }^{*}$. De keuze van de moeder is niet gericht op de behandeling van het kind. Zij kiest voor het traject van de sectio omdat het haar 
een uitweg biedt voor het risico van een intra-uteriene dood van haar kind. Haar paniek laat geen ruimte over om verder te denken dan de bevalling zelf. Alles wat er na de bevalling komt, zoals de mogelijkheid om Esther te behandelen, valt buiten haar blikveld. Met de keuze voor haar eigen handelingstraject bepaalt zij echter ook het traject van het kind: maximale interventie na de geboorte.

Ook de vader van Esther voelt de druk. In zijn angst voor alles wat er komen gaat en mis kan gaan, zoekt hij houvast in de getallen: welke kans op overleving heeft het kind? Het kind blijkt niet geheel kansloos. Het is deze hoop waarin hij de mogelijkheid van een uitweg ziet. Met het gebruik van het gevalsrepertoire kan hij deze hoop omzetten in een beslissing. Met de statistieken die de arts hem geeft, wordt namelijk niet alleen een bepaalde verdeling van overlevingspercentages binnengehaald. Het levert de vader van Esther ook een taal waarin hij de situatie kan verwoorden ('het is een kind met een kans') en hij zijn keuze kan rechtvaardigen ('het kind heeft recht op die kans'). Op basis van dezelfde percentages had de vader van Esther evengoed voor het traject van abstineren kunnen kiezen. Dan hadden de percentages niet zozeer gestaan voor een overlevingskans, maar voor het risico dat zij verwoordden: de geringe kans op overleven en de grote kans op handicaps.

Op het eerste gezicht lijkt de willekeur waarmee statistiek kan worden ingezet haar constructieve bijdrage aan een besluitvormingsproces te ondermijnen. Het is echter juist deze flexibiliteit die dit gevalsrepertoire tot een belangrijke component in een besluitvormingsproces maakt. Percentages zetten niet zozeer aan tot specifiek handelen, maar maken veeleer handelen mogelijk. Statistiek schraagt de beslissing en fungeert als steunpilaar op een moment waarop elk houvast welkom is.

Met een verwijzing naar de aanwezigheid van kansen verantwoordt de vader van Esther zijn besluit om een risico te nemen. Esther is voor hem echter niet op voorhand een kind met een kans. Dit wordt zij juist door haar situatie te relateren aan het traject van maximale interventie. Zonder interventie zou ze helemaal geen kans gehad hebben. In de verloskamer zijn de vragen 'wat is er aan de hand' en 'wat moeten we hier doen' geen afzonderlijke kwesties die achtereenvolgens een antwoord behoeven, zij liggen niet in elkaars verlengde, maar grijpen op elkaar in. De uiteindelijke keuze - na de geboorte van Esther - blijkt de uitkomst te zijn van een proces waarin tegelijkertijd de situatie wordt gedefinieerd en wordt vastgesteld hoe men behoort te handelen.

In het rapport Doen of laten' fungeert het domein van de feiten als uitgangspunt voor het besluit over hoe te handelen. In de verloskamer geldt dit domein juist als probleemgebied. Men weet immers niet wat het geval was, dus wordt een oplossing gezocht in de aanwezige handelingsopties. Niet de feiten maar de handelingsmogelijkheden fungeren in de verloskamer als uitgangspunt. In tegenstelling tot hetgeen de richtlijnen veronderstellen is de aanwezigheid van 
verschillende handelingstrajecten geen dilemma, maar een mogelijkheid om het proces weer vlot te trekken.

De verschillende handelingstrajecten worden in de richtlijnen van het rapport Doen of laten? als gelijkwaardige keuzes opgevoerd. Maar is dit wel zo? Zowel de praktijk in het Academisch Centrum als in het Northeastern General Hospital toont een duidelijke voorkeur voor het traject van maximaal ingrijpen na de geboorte. Waar komt deze voorkeur voor maximaal ingrijpen vandaan?

\section{Symmetrie}

Hoewel het rapport drie handelingstrajecten uitzet - niets doen, beperkte inzet van middelen of maximaal ingrijpen - bestaat er in de praktijk van zowel het Academisch Centrum als het Northeastern General Hospital een voorkeur voor het traject van maximale interventie. Deze asymmetrie kent verschillende achtergronden.

In de eerste plaats vloeit deze asymmetrie voort uit de aard van de consequenties. Wanneer er wordt besloten om van elke vorm van behandeling af te zien, heeft dit tot gevolg dat het kind na de geboorte overlijdt. Het irreversibele karakter van het afzien van behandeling doet men er vaak voor terugdeinzen om dit pad in te slaan.

In de tweede plaats houdt de asymmetrie verband met het handelingsimperatief dat er van kansen uitgaat. Niet ingrijpen betekent dat het kind helemaal geen kans heeft. Dit vraagt om een duidelijkheid die in de meeste gevallen niet voorhanden is. Alleen diagnoses als trisomie $13^{*}$, trisomie $18^{*}$ en anencefalie* bieden in principe de duidelijkheid dat ingrijpen niet zinvol is. Het tweede traject, dat een terughoudend beleid voorstaat, reduceert, volgens sommige artsen, juist de kans op een goede afloop. Bij een beperkte inzet van middelen zou een mogelijk aanwezige vitaliteit onaangesproken blijven. Voor artsen betekent levensvatbaarheid echter het vermogen van een kind om in leven te blijven, desnoods met behulp van maximale technologische ondersteuning. Want ook in de acceptatie van deze kunstmatige steun zou zich de vitaliteit van een kind tonen. Door het achterwege laten van technologische ondersteuning kan deze potentie verdwijnen. Zoals één van de neonatologen in het Academisch Centrum hierover zegt:

"We doen hier niet aan de "survivaltest" door een kind eerst 10 uur te laten "tonen" hoe sterk hij is. Want ga je daarna alsnog handelen dan heb je kansen laten liggen. Hoe eerder je problemen opvangt hoe beter. Zo niet dan heeft dat uiteindelijk schadelijke gevolgen voor het kind. Toch valt er niets over te zeggen. Vroeger liet je een kind met een bepaalde aandoening sterven. Dan lees je weer een studie waaruit blijkt dat die kinderen wel eens kans hebben. Dus ga je een volgende keer wel met die kinderen aan de slag." 
De asymmetrische aard van de consequenties wordt hier juist uitgebuit. Met het traject van maximaal ingrijpen kunnen de risico's die de andere twee handelingsmogelijkheden met zich meedragen, vermeden worden.

In de derde plaats is er een asymmetrie in de mogelijkheid om de beslissing in de tijd te verplaatsen. Alleen het traject van maximaal ingrijpen biedt de mogelijkheid om in een later stadium, wanneer men beter zicht heeft op de situatie van een kind, alsnog de behandeling te staken. Het besluitvormingsproces biedt zo een ontsnappingsroute uit het dilemma waar de betrokkenen in de verloskamer mee worstelen. Ze kunnen de beslissing ook voor zich uitschuiven. De neonatoloog wijst Esthers vader expliciet op deze mogelijkheid. De mogelijkheid om op het besluit terug te komen heeft er mede toe bijgedragen dat de vader van Esther het traject van maximaal ingrijpen prefereerde boven het afzien van behandelen. Hij zet de beslissing in de verloskamer als het ware tussen haakjes: alsof het nog niet om de echte definitieve beslissing gaat. Hij schuift de 'echte' keuze voor zich uit naar een tijdstip waarin er meer informatie over de conditie van het kind voorhanden zal zijn en er op basis van meer zekerheid een beslissing kan worden genomen over het behandelingsbeleid.

In de vierde plaats, tenslotte, is er een asymmetrie in de handelingsruimte. Het traject van maximaal ingrijpen ligt in het verlengde van het traject van een operatieve bevalling. De ene handeling - een keizersnede - lokt de andere handeling - het kind aan de beademing - uit. Met de keuze van Esthers moeder voor een operatieve bevalling, wordt de staf ook op het handelingstraject van maximaal ingrijpen gezet. Zo wordt Esther na haar geboorte opgenomen op de NICU van het Academisch Centrum.

Anders dan de richtlijnen in het rapport Doen of laten? veronderstellen, staat in de verloskamer niet de vraag 'hoe te handelen?' centraal, maar de vraag 'wat is er aan de hand? Wat is de prognose van dit kind?' In deze discussie worden de verschillende handelingstrajecten niet als gelijkwaardige opties beschouwd. Integendeel. Dit verschil biedt de betrokkenen de mogelijkheid om een afweging te maken en daarmee ook de kans om de beslissing voor zich uit te schuiven. Het moment dat er alsnog een beslissing over doen of laten moet worden genomen laat echter niet lang op zich wachten. Drie dagen later staat men voor de keuze tussen het continueren of het staken van Esthers behandeling. We weten de uitkomst van dit besluit. Maar waar kwam deze beslissing tot stand? Op welke plaats en op welk moment? 


\section{De functionaliteit van de relokatie}

Vaak wordt een stafvergadering als dé plek en hét moment gexien waar dé beslissing over levensbeeindigend handelen wordt genomen. Gefixeerd in de tijd en ruimte van de vergadering wordt er het besluit genomen om een behandeling te staken. De stafvergadering over Esther werd echter belegd omdat de arts naast de couveuse tot de conclusie was gekomen dat verder doorgaan geen zin meer had. Dit besluit was dus eerder de aanleiding voor de stafvergadering, dan de uitkomst. Het besluit om een behandeling te staken komt niet op één moment, noch op één plek, tot stand, maar ontstaat in een proces dat over tijd en ruimte is verspreid. Deze relokatie dient een doel. In de verplaatsing wordt een beslissing getest op zijn robuustheid. Een robuustheid die noodzakelijk is gezien de consequenties van beslissingen over levensbečindigend handelen. Naast het waarborgen van zorgvuldigheid biedt de relokatie ook de mogelijkheid om de verantwoordelijkheid van de beslissing over verschillende betrokkenen te verdelen, waardoor er een draagvlak ontstaat.

Voor de analyse van het proces waarin beslissingen over levensbeceindigend handelen tot stand komen ga ik terug naar het besluitvormingsproces over het staken van de behandeling van Esther.

\section{Robuustheid}

De verplaatsing van een beslissing over levensbeëindigend handelen heeft verschillende voordelen. Er worden rustmomenten ingebracht zodat een overhaaste beslissing onmogelijk wordt. Met elke verplaatsing wordt het besluit ook opnieuw afgewogen. Door de beslissing op verschillende plaatsen ter hand te nemen ontstaat er een diversiteit aan evaluatiemogelijkheden. In de contextuele wisseling wordt het probleem telkens opnieuw opgepakt, in stukjes geknipt en in een ander licht gezet. Wat in context A een vaststaand feit is, kan in context B ter discussie worden gesteld. De locatie waarin het probleem wordt besproken maakt dat aan bepaalde zaken meer belang wordt gehecht dan op een andere locatie; het maakt bepaalde feiten tot niet ter zake doende; opmerkingen ongepast, argumenten niet van toepassing en biedt meer of minder ruimte voor emoties. Laten we de beslissing volgen op zijn tocht door het besluitvormingsproces.

Het is op de NICU naast de couveuse dat de artsen de situatie van Esther als kansloos beoordelen en besluiten dat haar behandeling gestaakt dient te worden. Hier geldt haar vierdegraads hersenbloeding aan beide zijden van het hoofd als een slagboom die aangeeft: 'tot hier en niet verder'. De bloeding vormt zo een moreel omslagpunt van 'behandelen' naar 'afzien van behandelen'. Dergelijke feiten duiden op wel of geen kansloos of onleefbaar leven en markeren de grens tussen zinvol en zinloos handelen. Deze feiten worden zwaarder getest dan anderen. 
Er wordt daarom naar aanleiding van het besluit een stafvergadering belegd. Hiermee wordt de beslissing van de NICU naar de vergaderkamer verplaatst.

In de stafvergadering legt de arts-assistent de aanwezigen de vraag voor: 'Wat is het verdere beleid gezien de huidige problemen, rekening houdend met het leven van het kind in de nabije toekomst gezien het feit dat de prognose zeer slecht is?' Deze vraagstelling suggereert een openheid die er niet is. Deze vraag is vanaf het begin van de vergadering verbonden met een specifiek antwoord, namelijk, een abstinerend beleid. Niet de vraag, maar juist dit antwoord is de reden waarom ze met elkaar om de tafel zitten. Over het feit dat een kansloze of onleefbare situatic een abstinerend beleid geoorloofd maakt, daarover zijn ze het op de afdeling in het Academisch Centrum wel eens. Maar geldt dit ook voor Esther? Ja, is het antwoord bij de couveuse van Esther geweest. Maar blijft dit ook staan in de context van de stafkamer?

In de context van de stafkamer wordt dit omslagpunt aan cen krachtmeting onderworpen. Hiervoor neemt één van de neonatologen de rol van 'advocaat van de duivel' op zich. Niet orndat hij de intenties van zijn collega's wantrouwt. Nee, hij doet precies wat er van hem verwacht wordt in een dergelijke setting. Namelijk, het onder druk zetten van het voorstel zodat mogelijke zwakke schakels opgespoord kunnen worden. Met de aanwezigheid van artsen die niet direct bij de behandeling betrokken zijn ontstaat er een distantie die ruimte biedt aan andere facetten van het probleem. Er wordt gevraagd naar een EEG-uitslag en naar literatuur verwezen: 'Uit onderzoek blijkt dat een hersenbloeding op zich niet alles zegt, maar dat ook de locatic een rol speelt. En dat zie je niet op een echo.' Met dit voorbeeld uit de literatuur wordt in de stafvergadering het feit dat de hersenbloeding een uitzichtloze prognose impliceert, onder druk gezer. Ook de echo als prognostisch instrument boet in aan waarde. Binnen de stafvergadering blijkt het morele omslagpunt minder robuust dan naast de couveuse.

Welk feit als moreel omslagpunt dient, ligt niet tevoren vast. In het Northeastern General Hospital ligt Maureen eveneens met een vierdegraads hersenbloeding. Voor haar behandelend arts betekent deze diagnose echer geen 'onleefbaar leven prognose' maar 'een niet-dodelijke aandoening'. Wat hem betreft is een abstinerend beleid dus ook niet aan de orde. 'Want', zo zegt hij, 'een hersenbloeding is op zichzelf geen dodelijke aandoening. Bovendien kun je zelfs niet met zekerheid zeggen dat dit kind gehandicapt wordt. Er zijn immers een paar gevallen bekend waarvan de uitkomst minder ernstig was dan verwacht. Dit betekent dat je in de praktijk niets kunt zeggen over de uitkomst van een graad vier bloeding.' In dit geval wordt de hersenbloeding geen moreel omslagpunt. Waar voor de één een vierdegraads hersenbloeding aan beide zijden cen niet-dodelijke aandoening is en juist aanspoort tot behandelen, draagt zij voor een ander een onleefbare tockomst in zich die oproept tot het staken van cen behandeling. 
In de stafvergadering in het Academisch Centrum wordt echter niet alleen het feit onder druk gezet dat Esther een kind is dat in de categorie valt dat een abstinerend beleid rechtvaardigt, maar ook de categorie zelf. De gremzen die bepalen wat wel of niet binnen de categorie 'kansloos' of 'uitzichtloos' valt, worden door de 'opponerende' neonatoloog op een andere plaats gelegd. Enkel de zekerheid over de aanwezigheid van een vierdegraads hersenbloeding is voor hem niet voldoende. Immers ook de locatie in de hersenen is volgens hem van belang. Voor hem valt het kind pas binnen de categorie 'kansloos' als het een hersenbloeding heeft van een bepaalde omvang én deze op een bepaalde plaats is gelokaliseerd. Voor hem ligt daar pas de slagboom die aangeeft 'tot hier en niet verder'. Daar ligt voor deze neonatoloog pas het morele omslagpunt. Deze categorische grenzen vereisen ook andere prognostische bewijzen, zoals een EEG. Ook de echo-uitslag dient nu aan andere voorwaarden te voldoen: 'Ik denk dat, onafhankelijk van deze casus, het zorgvuldiger is bij dit soort besprekingen een op schrift gesteld verslag van de röntgenoloog te vragen.' In het gevalsrepertoire dat de neonatoloog hier hanteert zijn de grenzen van de categorie teruggesnoeid en is hulp van buitenaf noodzakelijk om deze grenzen te bewaken. De attending denkt echter niet 'onafhankelijk van deze casus'. Geen gevalsrepertoire, maar een situationeel repertoire is hetgeen waarmee hij de prognose van Esther beoordeelt. Binnen het kader van dit repertoire heeft de attending ook te maken met andere factoren, zoals gebrek aan tijd. Daarom zou enkel '... een bevestiging van één van de stafleden van de röntgen al volstaan'. In dit situationele repertoire geldt ook een andere lijst van feiten waarmee het kind binnen de categorie voor een abstinerend beleid valt. Zoals het feit dat '...het kind ook gedurende langere tijd ernstig gedecompenseerd geweest.' en dat '...het beeld van de hypotensie vrijwel zeker berust op een nog actieve bloeding'.

Maar hiermee zijn we er nog niet. Naast de inhoud van het feit en de aard van de categorie moet er ook nog overeenstemming komen op het niveau van repertoires. Beide repertoires schuiven een andere norm naar voren op basis waarvan de beslissing genomen moet worden. In de normatieve orde van het situationele repertoire is een echo voldoende bewijs, speelt een EEG geen rol en is een hersenbloeding graad vier aan beide zijden van het hoofd voldoende om een abstinerend beleid te rechtvaardigen. Zo niet in het gevalsrepertoire. Daar gelden andere normen om een dergelijk besluit te rechtvaardigen. In de normatieve orde van het gevalsrepertoire geldt enkel een echo als onvoldoende basis en is een officieel verslag van een radioloog als aanvulling noodzakelijk. In het gevalsrepertoire is een EEG een vereiste, evenals een specificering van de locatie van de hersenbloeding. Beide repertoires incorporeren elk een andere normatieve orde over waar een moreel omslagpunt aan dient te voldoen. Wat nu? Om uit deze impasse te komen ondernemen zowel de attending als de neonatoloog actief een poging om beide repertoires - en hun normatieve orde-met elkaar te verzoenen. 
De neonatoloog past de algemene eis van een EEG onderzoek aan door in te stemmen met enkel een consult van een neuroloog. Ook de voorwaarde dat een uitgebreid rapport van de radioloog noodzakelijk is, wordt aangepast aan de omstandigheden van de situatie. Accordering van het bestaande verslag is nu voldoende. De neonatoloog komt hiermee tegemoet aan de specificiteit dat een situationele repertoire vraagt. De attending, op zijn beurt, herformuleert zijn voorstel op zo'n manier dat het de voorwaarden van zijn collega voldoende incorporeert: 'Laten we afspreken dat één van de stafleden van Radiologie naar de echo kijkt en dat de kinderneuroloog geïnformeerd wordt over deze casus met de vraag of hij er nog iets aan toe te voegen heeft. Dan kunnen we daarna naar de ouders gaan.'

Het uiteindelijke resultaat van de stafvergadering wordt in de status genoteerd. Conform de eisen die een juist gebruik van de status met zich meebrengt is de discussie hier teruggebracht tot enkel een opsomming van de aanwezigen, een korte beschrijving van de prognose en het beleid. In dit geval wordt bij het beleid de voorwaarde verbonden dat het onderzoek van de radioloog en neuroloog de prognose moet bevestigen.

Vervolgens gaat er een aanvraag voor advies naar de neuroloog en de radioloog. Hiermee wordt het aantal direct betrokkenen uitgebreid. De radioloog bekijkt de echo van het hoofd en bevestigt de interpretatie van de attending. De kinderneuroloog onderzoekt het kind. Een korte blik in de couveuse is voor de neuroloog voldoende om de stand van zaken te beoordelen: '(...) Als ik dit zo bekijk, kan ik wel akkoord gaan met een abstinerend beleid. Al was het maar uit humane overwegingen'. Naast de couveuse speelt wetenschap en klinische ervaring een andere rol en domineert een ander taalgebruik. ${ }^{12}$ Deze context biedt meer ruimte om uiting te geven aan ook andere overwegingen en gevoelens. Hier klinkt 'Wat een triestheid' en staat de tragiek van de situatic op de voorgrond.

Eenmaal terug achter de tafel om zijn beslissing te verantwoorden in het neurologisch verslag, draaien voor- en achtergrond en overheerst opnieuw een medisch vocabulaire. De tragiek die aan het besluit om de behandeling te staken, vastzit, wordt hier in officiële medische termen gegoten. Om te beschrijven wat deze triestheid is, verwijst hij naar de cerebrale pathologie (echo); tensieproblemen; ervaring van anderen over eventueel te verwachten multi-orgaan problemen. Deze feiten dragen met elkaar een moraliteit aan die de voortzetting van de behandeling voorbij de grens van het toelaatbare plaatst. Het besluit heeft opnieuw zijn hardheid bewezen.

Nog eenmaal wordt het besluit verplaatst om bekrachtigd te worden. De behandelend arts legt de ouders van Esther het besluit voor. Het laatste woord is aan hen. Ook zij gaan akkoord.

In de discussie over het staken van de behandeling van Esther spreekt men voornamelijk in termen van een actieve bloeding, een kind dat ernstig gede- 
compenseerd is geweest, over het beeld van de hypotensie, een prognose, een echobeeld. Hier domineert een medisch vocabulaire." Bij een eerste lezing lijkt alleen de feitelijkheid ter discussie te staan en elk moreel standpunt afwezig. Alsof alleen de feiten tellen en men in deze praktijk geen moreel standpunt inneemt. Een dergelijke voorstelling van zaken doet geen recht aan zowel de integriteit van de betrokkenen als de complexiteit van de beslissing. Bovendien bevestigt een dergelijke conclusie het idee dat er een strikte scheiding bestaat tussen feiten en waarden. Weliswaar spreekt men bijvoorbeeld tijdens de stafvergadering - het moment waarop 'officieel' morele keuzes gemaakt dienen te worden - over medische gegevens. Dit betekent echter niet dat het handelen uitsluitend wordt bepaald door de feiten. Integendeel. Moraliteit blijkt er wel degelijk aanwezig te zijn. Als we kijken hoe de feiten werden vastgesteld toen ze nog niet als zodanig vaststonden, dan blijkt dat hier tegelijkertijd morele keuzes zijn gemaakt. Het testen van de prognose gaat gepaard met het toetsen van de waarde. Een kind categoriseren in de groep waarin een abstinerend beleid geoorloofd wordt geacht, blijkt tevens een beoordeling van wat feitelijk kansloos en normatief onleefbaar is. Wanneer zijn de vooruitzichten van een kind echter 'kansloos' of 'onleefbaar'? Bij een tweezijdige hersenbloeding graad vier, zegt de één. Nee, zegt een ander, bij een tweezijdige hersenbloeding graad vier plus een bepaalde lokatie. Dit maakt een EEG-uitslag en een radiologisch verslag over de echo van het hoofd noodzakelijk. In het geval van Esther zijn beide voorwaarden onhaalbaar. Situering van moraliteit vraagt meer dan het toepassen van algemene morele regels op een bijzonder geval. In de context van de stafkamer worden ook de grenzen van de categorie heen en weer geschoven. De voorwaarden om binnen een categorie te vallen en de categorieën zelf moeten op maat worden gemaakt. Zoals de situatie van het kind wordt beoordeeld in het licht van algemene termen van de categorie, wordt ook de categorie zelf gemodelleerd naar de specificiteit van de situatie van het kind. De mate waarin de voorwaarden mogen buigen en de grenzen van categorieën mogen wijken zodat het kind erin past, is de uitkomst van een onderhandelingsproces waarin de aanwezigen het gevalsrepertoire en het situationele repertoire met elkaar weten te verenigen. De definitie van de situatie van het kind (de feiten) en de definitie van de norm (de categorie) komt tegelijkertijd tot stand. ${ }^{4}$ Dit leidt tot een gesitueerde moraal waarin de tegenstelling tussen 'algemene categorieën' en 'de bijzondere situatie van het kind' is opgelost."

\section{Draagvlak}

Moraal gaat niet alleen over het testen van een prognose, het toetsen van waarden én het afstemmen van repertoires. $\mathrm{Zij}$ gaat ook, misschien zelfs meer, over de consequenties van handelen." De tragiek die aan levensbeëindigend handelen 
kleeft, brengt 'morele kosten' met zich mee. ${ }^{7}$ Op welke wijze wordt deze morele last verdeeld? Hoe vindt de toeschrijving van verantwoordelijkheid plaats?

Voor de geboorte van een kind ligt de beslissingsmacht bij de ouders en de moeder in het bijzonder. Het kind maakt immers nog deel uit van het lichaam van de moeder. Artsen hebben er dan niets over te zeggen. Esthers moeder had er bijvoorbeeld voor kunnen kiezen om af te zien van medische behandeling. $\mathrm{Ze}$ was dan opgestaan uit het bed en naar buiten gewandeld. Dit gebeurt echter niet. Zij blijft en moest een beslissing nemen over wat er moet gebeuren. Het juridisch beginsel van ouderlijke macht splitst de groep in de verloskamer in tweeën met aan de ene kant de medische staf en aan de andere kant de ouders. Door de ouderlijke macht ligt alle verantwoordelijkheid in handen van Esthers ouders. $\mathrm{Zij}$ moeten een keuze maken, of ze willen of niet. Het is aan artsen om ouders hierin bij te staan. Daarbij dragen de artsen zelf geen verantwoordelijkheid voor de uiteindelijke keuze."

$\mathrm{Na}$ de geboorte van een kind gaat de aanwezige neonatoloog over tot medische interventie en laat hiermee zijn louter adviserende rol achter zich. Tegelijk met het aankoppelen van een kind aan de beademing neemt de arts verantwoordelijkheid voor de behandeling op zich. In het Academisch Centrum draagt een arts deze verantwoordelijkheid voor de keuze van het behandelingsbeleid niet alleen, maar deelt deze met de andere leden van de medische staf. Nadat een behandelend arts bij de couveuse het besluit neemt dat verdere behandeling nutteloos dan wel onwenselijk is, wordt dit standpunt in een stafvergadering besproken. Met het recht zich hierover uit te mogen spreken nemen de deelnemers echter ook een andeel in de verantwoordelijkheid over de uiteindelijke beslissing. Deze ligt nu niet meer alleen op de schouders van de behandelend arts, maar wordt gedragen door de gehele medische staf en de overige aanwezigen. In het geval van Esther overschrijdt dit spreidingsbeleid zelfs de grenzen van de afdelingsmuren: ook een radioloog en een kinderneuroloog worden gevraagd mee te delen in de verantwoording. Anders dan de adviserende rol van de aanwezige neonatoloog in de verloskamer, kleeft er aan hun advies wel degelijk een medeverantwoordelijkheid voor het uitvoeren van een abstinerend beleid bij Esther. Ook de ouders van Esther moeten zich expliciet uitspreken over het besluit de behandeling van hun kind te staken. De staf is zich terdege bewust van de morele last die dit beslissingsrecht met zich meebracht. Tijdens de stafvergadering tracht de staf een deel van de morele last bij de ouders weg te nemen zonder aan hun beslissingsmacht te tornen."

In het verplaatsingsproces raken steeds meer mensen betrokken bij het besluit en wordt tegelijkertijd de morele last over verschillende schouders verdeeld. Met deze toename in betrokkenheid groeit het individuele beshit van de arts naast de couveuse gaandeweg uit tot een gezamenlijk advies van de afdeling aan de ouders. Een groot deel van de discussie in de stafkamer is gericht op een 
uitkomst waar iedereen zich in zou kunnen vinden. In deze zoektocht naar de juiste coördinaten verandert 'de beslissing' in 'een advies'. Op deze wijze wordt er een formulering gevonden waar iedereen zich in kan vinden. Vanuit dit opziche ligt de functionaliteit van de relokatic ook in het kneedbaar maken van de tragiek die in een beslissing over levensbečindigend handelen besloten ligt. In het proces van stollen en ontstollen van het besluit krijgen de betrokkenen de gelegenheid om zich het besluit eigen te maken. De ontwikkeling van 'wie wij zijn' en 'het besluit' lopen gezamenlijk op. De vorm waarin het besluit wordt genomen en de uitkomst van de beslissing weerspiegelt 'de morele identiteit' van de afdeling. In het besluit en de wijze waarop er met dergelijke beslissingen wordt omgegaan toont een afdeling haar 'morele gezicht'.

Een analyse van de wordingsgeschiedenis van een besluit maakt het normatieve karakter van locaties zichtbaar. Argumenten die naast de couveuse voldoende gewicht in de schaal leggen om het besluit te forceren de behandeling te staken, voldoen niet altijd in de stafvergadering waar het besluit moet worden bekrachtigd. Emoties die naast de couveuse opkomen, kunnen in een vergaderkamer misplaatst zijn of geen rol van betekenis spelen. Onderzoek naar het proces waarin een beslissing tot stand komt toont echter niet alleen welke waarden en normen er op de afdeling worden gehanteerd en waar en wanneer deze worden ingezet. Het laat ook zien hoe men met elkaar omgaat. Met andere woorden, een analyse van het proces waarin een beslissing tot stand komt, maakt ook machtsstructuren zichtbaar.

In het proces waarin een beslissing met betrekking tot levensbec̈indigend handelen tot stand komt, zijn de betrokkenen niet gelijkwaardig. Niet ieders stem weegt even zwaar. Ook niet in het Academisch Centrum. Wie heeft bijvoorbeeld de macht om een stafvergadering bij elkaar te roepen? Artsen wel en verpleegkundigen niet. Dit is in de situatie van Esthers behandeling geen probleem voor de verpleegkundige. In de behandeling van Tom ligt dat anders. De verpleegkundigen die voor Tom zorgen hebben veel eerder dan de artsen het punt bereikt waarop het continueren van de behandeling bij dit kind als zinloos wordt beschouwd. ${ }^{10}$ Hoewel zij hun mening via arts-assistenten en oudere verpleegkundigen naar de artsen laten doorschemeren, moeten zij echter wachten totdat ook de attending deze mening is toegedaan. Pas op dat moment wordt er een stafvergadering belegd en is het staken van de behandeling expliciet onderwerp van discussie.

Verpleegkundigen dragen niet de verantwoordelijkheid voor de behandeling en zijn niet in de positie om te bepalen of de behandeling wordt gestaakt en op welk moment dit zal gebeuren. Verpleegkundigen hebben echter wel direct te maken met de consequenties van het handelingsbeleid. Op het eerste gezicht lijkt het daarom niet meer dan redelijk dat ook verpleegkundigen in de positie moeten zijn om een stafvergadering bijeen te roepen. In de praktijk ligt dit echter 
ingewikkelder. In de eerste plaats heeft de analyse van het besluitvormingsproces laten zien dat de stafvergadering niet zozeer de plaats is waar het besluit wordt genomen, maar waar het reeds genomen besluit wordt 'gehard' door het besluit aan een krachtmeting te onderwerpen. Het besluit om de behandeling te staken was immers de aanleiding tot de stafvergadering. In de tweede plaats, omdat de voorgaande analyse heeft laten zien dat de setting waarin de beslissing wordt besproken er wel degelijk toe doet. Hoewel artsen en verpleegkundigen de vocabulaires en repertoires delen, geeft de setting van een stafvergadering meer of minder ruimte aan bepaalde argumenten. "Zo spelen de statistieken uit de medische literatuur een belangrijke rol in de uitkomst van de discussie. Met dit gevalsrepertoire zijn vooral de artsen bekend. Als artsen de opvatting van verpleegkundigen niet delen, is mede door de rol van dit type argumenten het pleit dan ook gauw beslecht in het voordeel van artsen.

Een officiële stafvergadering kan niet de ongelijkwaardige positie tussen arts en verpleegkundigen opheffen. Dit betekent echter nog niet dat onderling overleg zinloos is. Wat er gebeurt als er helemaal geen overleg plaatsvindt op een afdeling wordt duidelijk als we het proces in herinnering roepen waarin de beslissing over Maureens behandeling in het Northeastern General Hospital tot stand kwam. "Daar is geen enkel moment van gezamenlijk beraad. Niet in een stafvergadering, noch naast de couveuse. In het besluitvormingsproces over Maureens behandeling ontbreekt iedere vorm van gezamenlijkheid. Men staat of tegenover elkaar of voelt zich buitengesloten. Hier is men nooit met elkaar om de tafel gaan zitten om de situatie van het kind te bespreken. Hierdoor ontbreekt niet alleen de mogelijkheid tot inspraak, maar ook distributie van verantwoordelijkheid. In het Northeastern voelt iedereen op de eerste attending na, zich machteloos én verantwoordelijk. De neonatoloog die de tweede maand van Maureens opname attending is, kan er 's nachts niet van slapen. De ouders vrezen de handtekening en blijven thuis en een verpleegkundigen weigeren nog langer voor Maureen te zorgen. Maureen overlijdt uiteindelijk op de drieëntwintigste dag van haar opname enkele uren nadat ze van het beademingsapparaat is afgekoppeld.

Op de NICU van het Northeastern wordt een besluit omtrent het al dan niet staken van een behandeling niet gezamenlijk besproken, noch gezamenlijk gedragen. De betrokkenen bij de behandeling van Maureen zijn niet verenigd tot een 'wij'. In plaats daarvan is er gemopper, gedoe, onzekerheid en verontwaardiging. In deze situatie wordt macht en onmacht uitvergroot en komt het 'wij'-gevoel te vervallen. Bij de behandeling van Maureen is van meet af aan een 'wij hier' en 'zij daar' tussen de verpleegkundigen en de artsen; tussen de attending en de arts-assistenten als ook tussen de staf en de ouders. "Er is een scheidslijn tussen de machtelozen die geen beslissingsmacht hebben en de machtigen die moeten beslissen of ze nu willen of niet. In de dagelijkse gang van zaken 
hoeft deze verdeling tussen bevoegdheid en de daarbijbehorende verantwoordelijkheid geen probleem op te leveren. Het schept een duidelijkheid die van fundamenteel belang is voor de constructie van een praktische orde. De onderlinge verhoudingen zijn evident en iedereen doet wat hem te doen staat. Maar een conflict kan deze helderheid doen omslaan in een mistig gebied waarin niet meer duidelijk is waar de beslissing ligt. Wie is hier dan bevoegd te beslissen. Is het de arts? Zijn het de ouders? Of geen van hen en is het uiteindelijk de wet die de gang van zaken bepaalt? Er is niet éen centrum van macht, maar een kluwen van opinies, problemen, heterogene waarden en diverse feiten.

\section{Een ander traject, een andere orde}

Net als bij Esther en Maureen is ook na Toms geboorte gekozen voor het traject van maximaal ingrijpen. Maar anders dan Esther en Maureen ligt Tom na vijf maanden nog steeds op de NICU. Door een opeenstapeling van problemen is zijn situatie uitzichtloos geworden.

\section{Academisch Centrum}

Donderdag: Neonatologen druppelen één voor eén de NICU binnen. Vanmorgen is er grote visite en worden alle kinderen uitgebreid besproken door het voltallig medisch team. In afwachting van de visite kijken rwee neonatologen samen de laatste gegevens over Tom door. De grote visite begint. De arts-assistent doet bij elk kind verslag van het verloop, de problematiek en het beleid. De groep wandelt van couveuse naar couveuse. Het ene kind vraagt meer tijd dan het andere. Sommigen zijn stabiel en doen het goed. Anderen geven een complexer beeld te zien. Tom behoort tot de laatste groep. De groep formeert zich rond zijn couveuse. Hoewel bekend voor iedereen somt de arts-assistent de lange rij met problemen op: een hoge zuurstofbehoefte, nierstenen als gevolg van de lasix*, een maagzweer als gevolg van de corticosteroïden waardoor hij zijn eten niet meer goed kan verwerken, stuipjes als gevolg van toenemende druk in het hoofd, de drain die hiervoor uitkomst moest bieden blijkt iets te lekken. Naast zijn 'bekende' problemen is er ook een drukverhoging in het hart geconstateerd. Met alle gevolgen van dien.

De dienstdoende neonatoloog vult de arts-assistent aan, wijst op desastreuze ontwikkelingen van de afgelopen tijd en de slechte prognose die dit met zich mee brengt. Zijn longen zijn onherstelbaar beschadigd zodat hij niet meer buiten de ondersteuning van het beademingsapparaat kan. Gezien het feit dat Tom in een voortdurend gevecht met de tube van de beademingsslang verwikkeld is, maakt dit een toekomst aan het apparaat tot een eindeloze lijdensweg. Iedereen is het er over eens dat het zo niet langer kan. Elke kans op verbetering wordt uitgesloten en energie om een volgende crisis te boven te komen lijkt Tom ook niet 
meer te hebben. Er wordt besloten dat er maandag een gesprek met de ouders zal plaatsvinden omdat de toestand steeds verder verslechtert en er geen uitzicht op verbetering meer is. Voor dinsdag wordt een stafbespreking georganiseerd om het beleid definitief vast te stellen.

Maandag: De attending en de arts-assistent zitten in de ouderkamer met de ouders van Tom. De artsen hebben net uitvoerig uitgelegd hoe Tom er op dit moment voorstaat. De afgelopen maanden zijn opnieuw de revue gepasseerd. De rij met problemen die ter sprake komt is indrukwekkend. Sommigen zijn opgelost, anderen zijn nog steeds actueel, waarvan enkele als onoplosbaar worden gezien. Het gevoel van hoop en twijfel dat zich door de tijd heen bij Toms ouders had ontwikkeld, liet zich echter niet zo snel aan de kant zetten. Toms vader: 'Wij kunnen die beslissing niet aan. Als we zeggen "blijf maar doorgaan met behandelen", dan houden we hem misschien nog drie maanden langer in leven terwijl hij alleen maar extra lijden erbij krijgt. Als we nu zeggen "stop er maar mee", dan zouden we met een gevoel blijven zitten dat er misschien toch nog iets had kunnen gebeuren.

De ouders geven aan dat ze de beslissing niet durven te nemen en vragen de artsen om de beslissing te nemen. Deze stellen voor om over te gaan op een niet-reanimatic beleid. Toms ouders stemmen hier mee in.

Dinsdag: Vandaag vindt de stafvergadering plaats. Hierbij zijn alle neonatologen aanwezig, de betrokken arts-assistenten en verpleegkundigen en een maatschappelijk werker. In de vergadering wordt besloten de behandeling van Tom af te bouwen en niet meer in te grijpen in het geval van crisis. Later die dag brengt de behandelend arts de ouders op de hoogte. Zij stemmen hiermee in.

Wanneer bij Esther de behandeling wordt gestaakt, overlijdt zij enkele minuten later. Haar behandeling was hiermee ten einde. Niet in alle gevallen betekent het staken van een behandeling ook het eind van het traject. In de stafvergadering over Tom wordt besloten over te gaan op een niet-reanimatie beleid. ${ }^{4}$ Dit betekent dat hij niet meer behandeld zal worden en dat er ook niet meer zal worden ingegrepen wanneer hij in de problemen zou raken door bijvoorbeeld een bradycardie*. Tom zal echter wel de dagelijkse zorg krijgen.

Met dit beleid zet de staf een nieuw handelingstraject in: het traject van een niet-reanimatie beleid. Op dit traject worden geen controles en onderzoeken uitgevoerd. Hier heeft de techniek geen centrale rol, maar staat de apparatuur aan de zijkant en wordt het middenpad bewandeld door mensen die zich concentreerden op de zorg voor Tom. Voor een antwoord op de vraag 'hoe gaat het met 'Tom?' richt de blik zich nu niet op de monitor, maar wendt men zich tot het kind in de couveuse. Op dit traject heerst geen bedrijvigheid, maar rust. Met de berusting dat Tom beter af is met de dood dan met het leven, is voor 
Toms ouders echter ook een spanningsvol afwachten begonnen. Elk telefoontje kan het fatale bericht brengen. Hoe moeten ze de dag doorkomen? Ze zijn de uitputting nabij. Ook bij de staf is de spanning voelbaar. leder moment kan Tom zijn tube eruit werken of in een bradycardie schieten. Hoewel alle middelen voor reanimatie grijpklaar binnen handbereik hangen, is de inzet van techniek bij dit kind afgezworen. Het beleid vereist dat in geval van nood de handen op de rug worden gehouden." Het wachten is begonnen. Het loopt echter anders dan verwacht.

\section{Academisch Centrum}

De stafvergadering waarin het niet-reanimatie beleid voor Tom is vastgelegd is nu drie weken geleden. Sinds de afspraak is gemaakt de behandeling te betindigen, wordt Tom met rust gelaten. Deze rust lijkt hem goed te doen. Hij slaapt goed en reageert minder paniekerig. Hij is zeer actief, helder en eet goed.

Tom knapt op en toont genadeloos de gevolgen van de activiteiten die in het vorige handelingstraject centraal hadden gestaan. Het voorgaande traject van maximale interventie werd beheerst door het zoeken naar de juiste handelingskoers en dit vereiste een nauwkeurig beeld van de stand van zaken. Voor de verzameling van relevante informatic had Tom een eindeloze reeks aan interventies moeten ondergaan in de vorm van controles en onderzoeken. Nu bleck met terugwerkende kracht dat deze interventies medeverantwoordelijk waren geweest voor de ernstige achteruitgang van zijn conditie. Met Toms kracht neemt echter ook de twijfel over de juistheid van de beslissing toe.

Toms vader:

'Tom is nu veel beter dan twee weken geleden. Hij ziet er beter uit en is ook veel rustiger. Hij maakt nu ook soms contact. Soms kijkt hij mij wel minuten lang aan. Als hij me dan zo aankijkt dan weet ik niet meer of we wel de juiste beslissing hebben genomen. Je hebt geen grond om op te staan. Hoe meer ik mij in deze materie verdiep, hoe meer ik er achter kom dar we nog maar heel weinig weten van dit soort kinderen.'

De ouders van Tom zijn door zijn verandering niet meer zeker van de juistheid van hun besluit. Ze krijgen meer contact met hun kind dan ooit tevoren. $\mathrm{Ze}$ kunnen nauwelijks geloven dat hij er echt zo slecht aan toe zou zijn als hen door de artsen is verteld en ze vragen zich af of een niet-reanimatie beleid nog wel op zijn plaats is. Om aan hun twijfel een eind te maken verzoeken ze de artsen om opnieuw de conditie van Tom te bepalen. Hoewel de artsen niet van mening zijn dat Toms prognose is veranderd, gaan ze op dit verzoek in. Nog dezelfde dag wordt er nieuw onderzoek gedaan. Hiermee ontstaat er gedurende de nachtdienst bij de verpleging onzekerheid over hoe er in geval van nood gehandeld moet worden. Wat is nu het beleid? De combinatie tussen een niet-reanimatie 
beleid én een nieuwe aanvraag voor lichamelijk onderzoek, klopt niet en zaait verwarring. Op welk traject bevinden zij zich nu? Om aan deze twijfel een eind te maken, brengt een verpleegkundige dit tijdens de dagelijkse visite ter sprake.

\section{Academisch Centrum}

De verpleegkundige: 'Wat is eigenlijk de bedoeling van de onderzoeken bij Tom. Er was vannacht wat verwarring bij de nachtdienst. Ze wisten nu niet meer hoe ze moesten handelen als er iets mis zou gaan bij Tom."

De arts-assistent valt de verpleegkundige bij. Ook zij heeft moeite met de onderzoeken. Want wat wordt er met de uitslagen gedaan? De aanwezige neonatologen zien het probleem niet. Een van hen: 'Er is toch een duidelijke afspraak gemaakt. En mocht het beleid veranderen dan zal iedereen daarvan op de hoogte worden gesteld. Bovendien hoeven we niet te verwachten dat de uitslagen verbeterd zullen zijn.'

Zowel de verpleegkundige als de arts-assistent zijn er niet gerust op: 'Waarom zijn die onderzoeken dan ingezet? En wat moeten we doen als ze toch wel verbeterd zijn? Het beleid is tenslotte toch steeds geweest niets te doen. Hier valt het doen van onderzock ook onder?' De neonatologen blijven voet bij stuk houden. De attending: 'De onderzoeken zijn gedaan op verzoek van de ouders en aan het beleid zal niets veranderd worden. Mocht er aanleiding toe zijn dan zullen ze weer allemaal om de tafel gaan zitten. Ik snap het probleem van de nachtdienst niet. Et staat immers duidelijk in de status en in de verpleegklapper wat het beleid is en in de status staat vermeld dat de onderzoeken op verzoek van de ouders zijn."

Een van de andere neonatologen valt hem bij: 'We moeten de vraag van de ouders als een uiting van twijfel zien. Ze twijfelen aan de prognose op basis waarvan het beleid is uitgestippeld.

'Deze twijfel wordt door sommigen van ons gedeeld', merkt de verpleegkundige op. 'Er zijn veel verpleegkundigen die moeite hebben met dat beleid. Dat het beleid met drie stafverpleegkundigen is afgesproken wil nog niet zeggen dat de andere vijftig het er mee cens zijn.'

De attending: 'die drie verpleegkundigen vertegenwoordigden de hele verpleegkundige staf. Je mag niet van ons verwachten dat we vervolgens met een ieder van jullic individueel in discussie gaan.

'Ik vind dat er wel ruimte moet zijn om je gevoelens te kunnen ventileren', reageert de verpleegkundige.

Een van de neonatologen probeert de verpleegkundige gerust te stellen: ' $\mathrm{Na}$ tuurlijk houden wij rekening met jullie en zal er niets worden besloten zonder dat jullie het weten. Als er wat is dan willen wij altijd luisteren. Dat weet je, dat is altijd zo geweest. Maar wat denk je nu? Dat als de bloeduitslagen beter zijn dat zijn longen weer zullen genezen? Onmogelijk. Zijn longen zijn helemaal kapot. Wat er niet meer is kan ook niet meer genezen.' Afgesproken wordt dat her beleid hetzelfde is en blijft totdat er andere afspraken over gemaakt worden. 
Het draagvlak waarop het niet-reanimatie beleid rust, vertoont op dit moment scheuren. Met zijn heldere blik en ontspannen gedrag heeft Tom de robuustheid van het besluit om zijn behandeling te staken, ondermijnd. De onverwachte verandering in Toms gedrag zet zijn prognose onder druk en er rijst bij ouders en verpleegkundigen twijfel over de juistheid van de keuze voor een nietreanimatie beleid. De consensus van waaruit het nieuwe handelingstraject was ontstaan, valt nu uiteen. In de context van de NICU blijkt het DNR-besluit minder beheersbaar. De artsen trachten het tij te keren voordat de twijfel de overhand kriigt en wijzen op de onherstelbaarheid van de beschadigde longen. Een verandering van het behandelingsbeleid is dan ook voor hen niet aan de orde.

De ingezette koers blijft gehandhaafd. Maar dit gaat niet zonder problemen. Een niet-reanimatie beleid betekent niet dat een kind van het beademingsapparaat ontkoppeld wordt. Een dergelijke handeling behoort op een ander traject: het traject van actief levensbeëindigend handelen. Vóór de stafvergadering was het de schadelijke werking van de machine die op de voorgrond had gestaan en bepalend werd geacht voor de richting waarin de behandeling zich ontwikkelde. Ná de stafvergadering is de beademingsdruk nog even schadelijk, maar geldt deze niet meer als concentratiepunt van aandacht. Dit wil echter niet zeggen dat het beademingsapparaat een marginale positie in het geheel inneemt. Ook op het traject van niet-reanimatie is dit apparaat én van de hoofdrolspelers. Want met het beademingsapparaat is ook het bijbehorende script meegekomen. Dit activiteitenschema vereist nog steeds een geregeld vastplakken van de beademingstube op de bovenlip van Tom. Dit voorkomt dat de tube uit zijn keel schiet. Tom raakt bij deze verzorging altijd in paniek en stribbelt dan krachtig tegen. Hierdoor ontstaat het risico dat op het moment dat de oude plakker verwijderd zal worden om de nieuwe aan te brengen, de tube door Toms tegenstribbelen eruit kan schieten. Het DNR-beleid verbiedt echter een herintubatie, wat betekent dat Tom op dat moment zal overlijden. Een verpleegkundige die Tom verzorgt:

'Het beleid ten aanzien van Tom is voor ons heel moeilijk uitvoerbaar. ledereen is bang dat het hem of haar overkomt dat de tube eruit vliegt. Deze angst is nog groter geworden nu de ouders hebben aangegeven dat ze perse willen weten wie er dienst heeft gehad op het moment dat er wat met Tom gebeurt. Ze hebben dit op zo'n manier gezegd dat je niet direct denkt aan ouders die er over willen napraten. Het lijkt alsof ze je willen aanklagen. Doordat zijn ouders op een dergelijke manier reageren durft helemaal niemand meer voor Tom te zorgen. Het moet allemaal ook niet te lang meer gaan duren. Er zijn zelfs al verpleegkundigen geweest die hebben aangegeven dat ze op een dag "per ongeluk" achter de tube blijven haken met hun vinger. Dit betekent dus dat de verpleging zelf gaat ingrijpen. Dan is er eindelijk een eind gekomen aan deze afschuwelijke 
situatic. Het duurt allemaal al veel te lang. Dar beleid is afgesproken met drie verpleegkundigen als vertegenwoordiging. Maar het feit dat die andere vijftig het er moeilijk mee hebben daar wordt niet aan gedacht.'

De beslissing om over te gaan op een niet-reanimatie beleid heeft een routinehandeling, zoals het afplakken van de tube, getransformeerd tot een 'risicovolle' handeling. Op een ander traject, met een ander doel hebben dezelfde handelingen een andere betekenis. Het afplakken van de tube leidt bij dit kind in dit stadium van zijn leven tot andere verhoudingen dan in de stafvergadering was voorzien. De verantwoordelijkheid voor het besluit om de behandeling te staken wordt gedeeld door de verschillende betrokkenen. De last van de consequentie van het besluit ligt echter op de schouders van enkelen: de verpleegkundigen die Tom verzorgen. Zij kunnen zijn dood veroorzaken. Ook de dienstdoende artsen behoren tot het selecte gezelschap dat met de consequenties van het besluit te maken heeft. In geval van nood mogen ze alleen maar toekijken.

\section{Academisch Centrum}

Maandagavond: Het is rond tien uur. De hartslag van Tom zakt naar roo slagen per minuut. De aanwezige artsen en verpleegkundigen vrezen dat hij hier niet meet zelf uit kan komen. Volgens afspraak grijpt niemand in. De arts belt zijn ouders in de hoop dat Tom nog leeft als ze op de afdeling aankomen. Zijn hart gaat nu steeds langzamer. Een half uur later arriveren zijn ouders. Tom leeft nog steeds. Na overleg neemt zijn moeder hem voorzichtig in haar armen. Niet lang daarna svealjidt Tom. Opreatore bj' ajir moeder:

Tom is zes maanden oud geworden. Na zijn dood wordt de apparatuur uitgezet en valt de monitor stil." Maar daarmee is niet alles gezegd en gedaan. Nog eenmaal wisselen de betrokkenen van traject en stappen ze over op het handelingstraject dat zich na de dood van een kind aandient. Ook dit traject brengt een eigen orde met zich mee. Hier loopt men langzaam, met respect, en spreekt men een andere taal: met medeleven en zonder getallen. Op dit traject zijn geen zuchtende beademingsapparaten, geen knipperende monitoren of piepende alarmen. Hier heerst rust en is techniek zo ver mogelijk naar de achtergrond verdreven. Het is op dit traject dat Tom voor het eerst vrij ligt van alle apparatuur waarmee hij tijdens zijn leven verbonden is geweest. Zijn bestaan op de NICU heeft zich gekenmerkt door een constante verstrengeling met de technologie die rond zijn couveuse stond opgesteld. Pas na zijn dood kan deze band verbroken worden en komt er een eind aan zijn hybride bestaan." Eenmaal los van alle draden en slangen kan hij babykleertjes dragen en door zijn ouders in de armen genomen worden.

De dood van het kind markeert de overgang naar een nieuw traject en daarin staat de ouder centraal." Ook op dit traject speelt de emotionele band tussen 
ouder en kind een belangrijke rol. Na het overlijden van hun kind komen ouders in een rouwproces. De staf probeert hen voor zover dat in hun vermogen ligt, te helpen om het verlies van hun kind op te vangen. Hierbij heerst de opvatting dat ouders dit verlies beter kunnen dragen als ze een goede emotionele band met het kind hebben gehad. Binden om los te kunnen laten, is hierbij het achterliggende idee." Een goed contact met het kind zou het schuldgevoel van ouders verminderen en hun eigenwaarde versterken. Het is vanuit deze achtergrond dat Toms moeder hem op schoot krijgt zodat hij in haar armen kan sterven." Na zijn overlijden zitten zijn ouders nog een hele tijd met hem alleen in de ouderkamer om rustig afscheid van hem nemen. Ook de ouders van Esther hebben haar na haar dood bij zich gehad. Haar moeder:

'Nadat Esther was overleden wilde ik haar niet meer zien. Maar de verpleegkundige heeft toen aangeraden om het toch te doen. Ze zeiden dat we er anders spijt van zouden kunnen krijgen. Ik heb toen gezegd: Goed, doe dan maar. Toen ik haar met het bedje aan zag komen rijden schrok ik enorm en wilde ik eigenlijk direct weglopen. Maar toen ik haar zag en zag hoe rustig ze er bij lag viel alles van me af:

\section{Haar vader:}

'Dat is de mooiste herinnering die we aan Esther hebben. Toen pas kon ik haar voor het eerst vasthouden. Toen ik haar in mijn armen had en tegen me aan kon drukken, toen kwam er zo'n groot vadergevoel los. Ik voelde heel sterk dat ik hierna nog een kind wilde. Ze had zo'n lief gezichtje. Ik zou het nu dan ook iedereen aanraden. Het leek me heel eng, maar het deed ons zo goed.'

Ook op andere manieren tracht men ouders te helpen bij het rouwproces. In het Academisch Centrum worden er voor dit doel foto's van het kind gemaakt nadat het is overleden. Willen ouders ze op dat moment niet hebben, dan worden ze voor hen in de status bewaard. Mochten ze zich later bedenken dan kunnen ze altijd worden opgevraagd.

Ook van Tom zijn foto's gemaakt als herinnering voor zijn ouders. De foto's tonen hem in met een mooi blauw pakje, witte sokjes én zonder de tube van de beademingsslang in zijn neus. Vooral het laatste maakt een groot verschil. Met terugwerkende kracht wordt zichtbaar hoe de tube en het tape waarmee het was bevestigd, gezichtsbepalend zijn geweest. Zo zonder tube en tape lijkt hij haast een ander kind. Maar niet enkel zijn gezicht is 'leeg': ook zijn couveuse. De aanwezigheid van Tom is na al die maanden 'gewoon' geworden op de afdeling. Het is dan ook een vreemd gezicht om de dag na zijn overlijden een lege couveuse op zijn plek te zien staan. Ondanks de ongewone aanblik heerst er een gevoel van opluchting op de afdeling." De arts-assistent die nachtdienst had tijdens het overlijden van Tom: 
'Ik was al bang dat het in mijn dienst zou gebeuren. Ik zag het helemaal niet zitten als er iets met die tube zou gebeuren. Gelukkig liep het anders. Hij is heel rustig ingeslapen. De ouders hebben heel lang in de ouderkamer met Tom op schoot gezeten. Ik had jammer genoeg nauwelijks tijd om met de ouders te praten. Er kwam namelijk op hetzelfde moment ook een nieuwe opname binnen. Dit was een prematuur van zesentwintig weken en die vroeg al onze aandacht.'

Een van de verpleegkundigen uit het Academisch Centrum:

'Het had niet mooier kunnen gaan. Nu is er niemand die met een schuldgevoel achterblijft. Tom heeft het helemaal zelf gedaan. Het ging allemaal heel rustig. Als een kaars die langzaam uitging.'

Met Toms overlijden ebt de spanning weg die zich rond zijn couveuse had opgebouwd. Een spanning die voortkwam uit een samenloop van omstandigheden, beslissingen, handelingen en interacties tussen mensen onderling en tussen mens en techniek. Dit alles had onbedoeld tot een situatie geleid waarin Toms kwaliteit van leven als onvoldoende werd beschouwd en hierin geen verbetering viel te verwachten.

Op de NICU worden veel beslissingen genomen. Sommigen daarvan zijn direct of indirect gerelateerd aan de kwaliteit van het leven van het kind en/of de ouders. Dit noemen we 'morele beslissingen'. Deze morele beslissingen vormen echter geen aparte categorie naast feitelijke of medische beslissingen. In theorie gaat moraliteit over 'het goede leven', over 'hoe juist te handelen', en richt men zich op de relatie tussen ethische principes en de situatie van het kind. Via

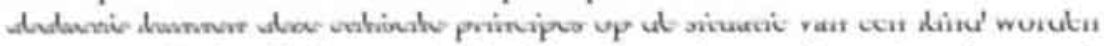
toegepast. Op de afdeling wordt dit deductieve schema echter niet gehanteerd. Hier vraagt een morele keuze een andere activiteit dan het toepassen van algemene morele regels op een unieke situatic. In de praktijk van de NICU moet moraliteit op maat gemaakt worden. In feite blijkt moraliteit te gaan over het aanbrengen van een moreel omslagpunt: de grens van 'tot hier en niet verder'. Hier betekent moraliteit afbakenen. Deze demarcatie komt tot stand door een reeks van uiteenlopende activiteiten op diverse plaatsen en verschillende momenten. Moraliteit op maat maken vergt het testen van de robuustheid van feiten en de rekbaarheid van morele categorieën; het onderzoeken van de handelingsruimte; het zoeken naar de juiste woorden; het creëren van een draagvlak; het aftasten van disciplinaire grenzen en het verdelen van verantwoordelijkheid; en leren om te gaan met de consequenties van het besluit.

Op de afdeling is sprake van een situering van moraal waarin het onderscheid tussen 'algemene morele categorie' en 'de unieke situatie van het kind' oplost. Toch worden morele beslissingen vaak als aparte categorie naast medische beslissingen gezien. Hoe kan dit? De oorzaak hiervan moet worden gezocht in de reflectie. Het is pas achteraf, in de reflectie, dat deductieve morele besluiten op ons netvlies zichtbaar worden. 


\section{Het einde van de reis}

Met het overlijden van Tom komt een einde aan zijn leven, maar niet aan zijn geschiedenis. Zijn dood zet een proces van terugblikken in gang om verder te kunnen gaan. In dit afsluitende hoofdstuk staat deze achterwaartse blik centraal. Maar niet alleen van hen die betrokken waren bij de behandeling van Esther, Tom en Maureen. Ook ik blik terug op het voorgaande en kom terug op de vragen die ik aan het begin van dit boek heb geformuleerd.

\section{Momenten van reflectie}

De beschreven gevallen laten zien dat een beslissing die tijdens een stafvergadering wordt genomen er slechts één van vele is. Voor een beter begrip van de wijze waarop morele keuzes tot stand komen, is het dan ook noodzakelijk om een dergelijk besluit te situeren in een tijdspanne die verder reikt dan enkel een stafvergadering of een discussie in een verloskamer. Met het uitbreiden van de tijdspanne waarop de reflectie is gericht, komen dergelijke keuzes in een ander licht te staan. In het geval van Maureen blijkt de keuze voor maximale interventie deel uit te maken van een proces dat jaren voor de geboorte reeds is ingezet. Het leven van Maureen bleek al voor haar conceptie verknoopt te zijn met technologische interventies, statistische kansen en actieve medische bemoeienis rond haar bestaan. Het aankoppelen van het beademingsapparaat in de verloskamer werd hiermee een 'logische stap' in een proces dat al maanden gaande was, maar nog zeker niet was afgerond. Maureen was 'een investering' waarmee reeds veel 'moeite en geld' was gemoeid. De hoge leeftijd van haar ouders maakte bovendien de kans op nogmaals een succesvolle IVF-behandeling erg klein. Hiermee werd haar behandeling 'een zaak van redden wat er nog te redden valt.'

Niet alleen de specificiteit van de situatie verdient aandacht, maar ook die van het proces waarin de behandeling vorm krijgt. Dit maak het begrijpelijk dat bij kinderen met een overeenkomstige medische problematiek de keuze een behandeling te starten of te beëindigen een andere uitkomst kent. Dergelijke beslissingen staan niet op zichzelf, maar is nauw verweven met voorgaande gebeurtenissen en besluiten en datgene wat in het verschiet ligt. Dit zet een 
conceptualisering van een morele keuze als een besluit dat op één bepaalde tijd en plaats wordt genomen, onder druk. De notie van een morele keuze als 'moment' ontstaat pas in de reflectie op dergelijke besluiten. In die morele reflectie wordt het handelingsproces als het ware stilgezet om vervolgens in te zoomen op één plaats en één moment. Doorgaans is dit een stafvergadering waarin stafleden met elkaar het besluit bespreken een behandeling al dan niet te continueren. In dit retrospectief ziet men een afdeling die keurig is ingedeeld in een wereld van feiten en een wereld van waarden. Het is een domein waarin duidelijk is wat hoofdzaken en bijzaken zijn. Met deze temporele en lokale fixatie blijven echter verschillende aspecten buiten beeld, zoals het proces waarin de keuzesituatie is ontstaan, inclusief de wisselwerking tussen de betrokkenen, alsook de contingente gebeurtenissen op het traject en de machtsstructuren op de afdeling. In de reflectieve fixatie worden morele kwesties als het ware losgeweekt uit de geschiedenis van de situatie waarin ze zich voordeden en teruggebracht tot conclusies van meer of minder rationele overwegingen. De 'ruis' - zoals onderlinge onenigheid, de frustraties over een kind dat voortdurend met de tube ligt te worstelen, labuitslagen die zoek zijn of niet kloppen, ouders die weigeren te komen - is eruit gefilterd. Ethische reflectie verrijst zogezegd uit de orde die de terugblik met zich meebrengt. Is de afloop van het verhaal bekend, dan kunnen handelingen een ethische interpretatie krijgen waarover vervolgens weer gediscussicerd kan worden.' Dat is nu precies het bijzondere aan reconstructies.

Zoals uit het voorgaande is gebleken, is de wereld van de NICU alles behalve een overzichtelijke wereld. Hier komen waarden niet voor of na de feiten, maar lopen deze door elkaar. Op de NICU heeft men te maken met organische, procesmatige ontwikkelingen die zich volgens het draaiboek voltrekken, maar die ook in een stroomversnelling terecht kunnen komen of geheel vast kunnen lopen. De context van beslissingen is hier bijna altijd schimmig en per definitie in beweging. Dit bemoeilijkt het zicht op het geheel. Of zoals een neonatoloog van het Academisch Centrum het uitdrukt:

'Soms ben je eigenlijk alleen maar bezig met het oplossen van de afzonderlijke problemen. Dan weiger je op te tellen. Je blijft bezig met het zoeken naar mogelijkheden om het ene probleem na het andere probleem op te lossen. Daar ben je dan zo druk mee in de weer, dat je het totale beeld niet ziet. Dat wil je op zo'n moment eigenlijk niet zien. Je hebt immers nog steeds ruimte om iets te doen. Maar als je daar dan later weer op terugkijkt, besef je dat het eigenlijk toen al niet goed zat.'

Moeten we op basis van het voorgaande concluderen dat alleen buitenstaanders kunnen reflecteren op hetgeen zich op de NICU afspeelt en dat de betrokkenen zelf enkel worden meegevoerd op de stroom van de immer aanwezige dynamick van het handelingsproces? Deze conclusie is voorbarig want ook op de NICU zijn er reflectieve momenten ingebouwd. De stafvergaderingen over Esther en 
Tom zijn hier duidelijke voorbeelden van. Ook de bijeenkomst van de arts met de ouders nadat hun kind is overleden. Enkele weken na het overlijden nodigt de behandelend arts de ouders uit om samen terug te kijken op het verloop van de opname van het kind. Op deze wijze tracht de staf de ouders te helpen bij de verwerking van het verlies van hun kind. Voor ouders wordt terugkijken zo een manier om verder te kunnen gaan. Een toekomst zonder hun kind dient zich al direct bij thuiskomst aan. Twee dagen nadat Esther is overleden vertelt haar vader hoe hij en zijn vrouw de eerste dagen proberen door te komen:

'We leven nu in een film. Alles is zo snel gegaan dat we het niet kunnen bevatten. Morgen wordt Esther begraven en daarna gaan we naar huis. Daar zien we heel erg tegenop. Dan is de film afgelopen en vallen we in een gat. Mijn vrouw gaat eerst bij haar moeder logeren omdat de hele kinderkamer al kant en klaar is. Die ga ik helemaal leeghalen. We houden een klein schoenendoosje met het mutsje wat Esther in het ziekenhuis op had en het kaartje dat aan de couveuse hing en dat soort dingen. De rest gaat in een grote doos en wordt ergens achter op zolder gezet. En als er weer een nieuw kindje komt, kopen we alles opnieuw. Dit zijn Esthers spullen en dat blijven ze.'

Je leert in zo'n periode wel je vrienden kennen. Dat blijken er dan minder te zijn dan we gedacht hadden. Dan zijn er ook nog van die mensen die zeggen: 'ach, jullie zijn nog jong. Je kunt nog zoveel andere kinderen krijgen.' Die snappen er dus echt niets van. Maar ja, daar moeten we dan maar doorheen.

Er zijn op de NICU ook momenten van reflectie die een meer structureel onderdeel van de praktijk vormen. Zo komt de medische staf van zowel het Academische Centrum als het Northeastern General Hospital geregeld bij elkaar om te reflecteren op behandelingen die niet succesvol konden worden afgerond. In deze besprekingen staat het medisch verloop centraal. Met terugwerkende kracht oordelen de artsen over de handelingen en besluiten. In het Academisch Centrum zijn er ook multidisciplinaire patiëntenbesprekingen waarin artsen en verpleegkundigen samen de situatie van de kinderen bespreken. Deze momenten van bezinning worden echter dikwijls als eerste geofferd in het hectische NICU-bestaan. Dit is niet zozeer een kwestie van onwil, maar van onmacht. Werkdruk en een tekort aan personeel maken het bijkans onmogelijk om tijd te vinden om iedereen rond de tafel te krijgen. Hoewel het begrijpelijk is dat de prioriteit bij de handelingen aan de couveuse wordt gelegd, mag de waarde van dit soort besprekingen niet worden onderschat. In het Academisch Centrum bleken de werkbesprekingen enkele maanden achter elkaar afgelast door praktische omstandigheden. Sommige verpleegkundigen kregen hierdoor het gevoel dat er geen enkele mogelijkheid meer was om hun visie op het behandelingsbeleid te geven. De verpleegkundigen die voor Tom zorgden vonden de concrete uitvoering van het niet-reanimatie beleid erg zwaar, maar hadden het idee dat ze 
hiervoor geen oor vonden bij de artsen. Daarom vroegen zij een werkbespreking aan. Ook deze bespreking ging uiteindelijk niet door omdat Tom de dag ervoor overleed. Hiermee viel de concrete aanleiding voor de bespreking weg, maar niet het meer algemene belang ervan. Eén van de verpleegkundigen beklaagde zich hierover tijdens het verpleegkundig overleg:

'Ik vind het niet terecht dat de bespreking over Tom niet is doorgegaan. Alsof het alleen over Tom zou gaan. Het zou ook over het beleid gaan. Hier krijgen ouders voldoende steun, maar ik vind dat er te weinig steun is voor de verpleging. Daarom vind ik dat die bespreking alsnog moet doorgaan.'

Hier zijn normen van een andere orde in het geding. Normen die belangrijk zijn voor de constitutie van de praktijk. Ook deze normen werken door op de wijze waarop een probleem wordt geïnterpreteerd.

De staf gaat niet voor elke behandeling rond de tafel zitten. Veel behandelingen zijn routine en vragen nauwelijks enige nabespreking. Wanneer verandert echter een routinegeval in een uitzonderlijk geval? Dat is niet altijd duidelijk. Een verpleegkundige uit het Academisch Centrum vertelt hierover:

'Bij Tom is het allemaal sluipend gegaan. Na een maand behandelen zie je al niet meer wat je doet en weet je ook niet dat hij er over een half jaar nog ligt. Op een dag wandel je 's morgens de afdeling op en realiseer je je ineens hoe lang hij hier al ligt. Er zit altijd wel een kind tussen zoals Tom en op een dag loopt het af. Er wordt eigenlijk te weinig gesproken over wat er met hem gebeurt. Ook bij de verpleging onderling. Ja, alleen zo nu en dan in de wandeigangen hoor je wel iers in termen van: ach Tom. Zo zielig. En die ouders dan. Je weet ook niet wat artsen ervan vinden. Wat zij voelen als ze ernaast staan. Wat er door hen heen gaat als ze met Tom bezig zijn.

Op een gegeven moment kom je op een punt dat niets meer helpt. Dan ben je op de grens van behandelen en mishandelen gekomen. Ik ben er een tijdje terug voor een half jaar uitgeweest om dingen weer eens op een rijtje te zetten. Juist dit soort dingen vragen dat.'

Niet alleen voor ouders, maar ook voor stafleden is terugblikken een manier om verder te kunnen gaan.

Buiten formele bijeenkomsten vindt ook reflectie plaats. Stafleden praten tijdens koffie- en lunchpauzes na over de kinderen die ze onder hun hoede hebben gehad. Ook over Tom werd er nagepraat op de afdeling. Hoewel opluchting overheerst, kwamen er na zijn dood ook vragen los als: Hadden we eigenlijk deze beslissing niet veel eerder moeten nemen? Waarom zijn we überhaupt begonnen? Waarom hebben we niet eerder besloten tot het staken van de behandeling? We wisten eigenlijk toch al heel lang dat Toms kansen verkeken waren? 


\section{De geschiedenis herschreven}

Kennis van de ontknoping van een verhaal maakt een wereld van verschil. In hun terugblik op de behandeling van Tom zien de betrokkenen een keurige wereld geordend in feiten en waarden en hoofd- en bijzaken. In het licht van dit beeld kunnen zij reflecteren op de verrichte handelingen en de genomen besluiten. Het eens zo grillige handelingstraject is nu een logisch verhaal, dat open is voor interpretatic. Wat direct na de geboorte nog als juist handelen werd gezien (maximaal ingrijpen), verliest bijvoorbeeld zijn vanzelfsprekendheid. Nu het uiteindelijke resultaat van de behandeling bekend is, verliest het al zijn glans en heroïek. De betrokkenen denken echter verschillend over de oorzaak van Toms misère. Opnieuw vindt er een herverdeling van verantwoordelijkheid plaats. Voor één van de verpleegkundigen ligt de schuld van het verloop van de behandeling bij de artsen:

'De artsen hebben de ouders een veel te positief beeld voorgehouden, waardoor deze hoop bleven koesteren en op basis hiervan bleven aandringen op reanimatie. Bovendien hebben we het gevoel dat de artsen zich steeds vaker achter theoretische kansen verschuilen en alles gebruiken wat ze aan technische hoogstandjes tot hun beschikking hebben, zodat ze de verantwoordelijkheid niet op zich hoeven nemen een behandeling van een kind te staken. Het lijkt wel of de artsen een dergelijke beslissing niet meer durven te nemen en hem dus steeds maat weer voor hen uitschuiven. Zo krijgt een kind geen kans om te sterven."

Voor deze verpleegkundige is Tom geen kind dat de mogelijkheid tot leven heeft gehad, maar een kind dat niet mocht sterven. Voor haar ligt 'goed doen' ook in het toegeven van onmacht en je handen er vanaf durven trekken. De behandelend arts erkent dit principe maar verschilt met haar van mening omtrent het tijdstip van de beslissing om van verdere behandeling af te zien:

'Het is de aanwezigheid van reële mogelijkheden geweest die ons tot continuering van Toms behandeling heeft doen besluiten en niet de situatie waarin het kind zich bevond in termen van pijn en ellende. Emotionaliteit mag nooit de basis zijn van dergelijke beslissingen. Het zou de geneeskunde kunnen doen afglijden naar het niveau van "we kunnen er niet tegen, geef het maar een spuitje". Daarbij komt dat veel ellende niet door ons veroorzaakt is, maar een gegeven was waar we mee te maken hadden. Of we wilden of niet.

Daarnaast kunnen we ook niet om het oordeel van ouders heen. De ouders van Tom zagen alles veel te positief. Bij zijn laatste reanimatie hebben we dan ook alles uit de kast moeten halen om hem "terug te brengen". Het feit dat een kind er iedere keer weer bovenop komt zegt echter niets over een volgende keer. Maar dat schenen zijn ouders niet te willen horen. Ze bleven dwars door alles heen hoop houden en drongen dan ook voortdurend aan op reanimatie.' 
Ook de arts-assistenten praten tijdens een lunch over de behandeling van Tom:

'Bij Tom zijn we veel te lang doorgegaan. We wisten immers dat hij dood ging.' 'Maar ja, wij zijn niet de enigen die hier iets over te beslissen hebben. De ouders zijn er ook nog.'

'Maar iedereen had er anders behoorlijk veel moeite mee. Wij gaan door ook al zien we niet altijd de zin ervan in. Maar onze bazen willen dat zo. Ze zijn daarin heel duidelijk: wij zullen altijd handelen. Ze zeggen dat wij niet kunnen oordelen over andermans kwaliteit van leven en daarom altijd moeten handelen. Toch heb ik daar heel veel moeite mee.'

'Wel nee, over tien jaar praat je net zo als onze bazen en behandel je alles. Zo worden we immers opgevoed.'

De laatste opmerking van een van de arts-assistenten roept een beeld op van neonatologen als artsen die zonder enige reflectie altijd alles willen proberen. Maximale interventie sluit reflectie echter niet uit. Een van de neonatologen uit het Academisch Centrum kijkt als volgt terug op de behandeling van Tom:

'Als je dan zo'n proces ziet van zes maanden van ellende en het uiteindelijke resultaat is dat het kind overlijdt, dan zet je vraagtekens bij wat je doet. De neonatologie ontwikkelt zich heel sterk. Maar of de maatschappij er nu beter van wordt of de ouders er gelukkiger mee zijn? Dat vraag je in dergelijke situaties wel af. Maar je kunt niet van tevoren inschatten hoe het gaat lopen. Je weet niet van tevoren of een kind het haalt of niet en wanneer hij dan zal sterven. Daarom haal je er alles uit wat erin zit. Alle mogelijkheden benut je. Tot je helemaal niet meer verder kunt gaan. Tot je met je rug tegen de muur staat. Pas dan moet je zeggen: "we kunnen niets meer" Maar dat weet je niet op het moment dat zo'n kind geboren wordt en je aan de slag gaat. Natuurlijk kijk je wat je in je handen hebt. En als een kind echt heel erg onderontwikkeld is dan trek je je handen er vanaf. Maar normaal gesproken ga je cerst handelen en dan pas denken.'

Voor de ouders van Tom is het antwoord op de vraag of er juist gehandeld is niet geheel duidelijk. Voor hen kleeft aan elke beslissing te veel schuld om een duidelijke keuze te kunnen maken. Toms vader:

"Als we hadden gezegd "blijf doorgaan met behandelen" dan hadden we hem misschien nog drie maanden langer in leven gehouden. Misschien drie maanden lijden erbij. En als we hadden besloten met de behandeling te stoppen waren we met een gevoel achtergebleven dat er misschien toch iets had kunnen gebeuren en dat we Tom die kans ontnomen hadden. Wat we ook zouden beslissen, het zou een gevoel van twijfel en schuld bij ons achterlaten. Daarom konden we de beslissing niet aan en hebben we hem bij de artsen gelegd. Maar nu we zeker zijn van zijn dood, vragen we ons wel eens af in hoeverre zijn tweelingbroer er niet beter vanaf is gekomen. Die stierf immers direct na de bevalling.' 
Voor Toms vader is de morele juistheid van de beslissing om aan het begin van Toms leven in te grijpen door de uiteindelijke gevolgen van de behandeling onder druk komen staan. Zijn twijfel maakt de betrekkelijkheid van morele juistheid zichtbaar. De consequenties van de beslissing om een behandeling te starten, hebben artsen immers niet geheel in de hand. Bijkomende effecten, onvoorziene risico's en contingente gebeurtenissen kunnen de uitkomst van een beslissing een onverwachte wending geven. Dit maakt de juistheid van de beslissing fragiel.' Er komt altijd een zekere dosis 'moreel geluk' bij kijken of een beslissing om tot behandelen over te gaan ook aan het cind van het behandelingstraject als juist wordt gekwalificeerd.' Kinderen kunnen immers anders reageren dan ze volgens de boeken 'behoren' te doen; geneesmiddelen slaan niet aan, infusen kunnen nauwelijks ingebrache worden als gevolg van 'moeilijke vaten', apparaten blokkeren handelingsopties en hun negatieve bijwerkingen krijgen de overhand. Ook met een maximale inzet en een maximale kans van slagen kan leed niet voorkomen worden. De behandeling van Tom toont het paradoxale effect van medisch handelen in zijn meest schrijnende vorm: iedere poging Tom te helpen deed hem juist dieper het moeras inzakken. In de behandeling van dit kind zien we de structuur van een tragedie: wat er ook gedaan wordt en alle goede bedoelingen ten spijt, het doet het kind geen goed.

\section{De situering van kennis en moraal}

Aan het begin van dit onderzoek heb ik mij de vraag gesteld hoe men op de NICU omgaat met de problemen van de behandeling van pasgeborenen. De beschreven gevallen in het Academisch Centrum en het Northeastern General Hospital laten zien hoe ingewikkeld de behandeling van kinderen op de NICU kan zijn: de toestand van het kind moet voortdurend worden bepaald; de ouders moeten worden ingevoegd in het dagelijks ritme van de afdeling; het verloop van de ziektegeschiedenis moet onder controle worden gehouden; er moeten keuzes worden gemaakt over de inzet van apparaten, de interpretatie van gegevens, het continueren van de behandeling en de rol van de ouders in deze beslissing. Vraagstukken van verschillende aard en urgentie spelen hierbij een rol: wie is het kind? Slaat de behandeling aan? Hoe ziet de toekomst van dit kind eruit? Is er nog een kans dat hij van de beademing afkomt? In de meeste gevallen weet de staf het handelingsproces tot een goed einde te brengen. In de behandeling van kinderen op de NICU is het spanningsveld tussen vertrouwd en vreemd, controle en contingentie, zekerheid en twijfel, cohesie en conflict echter nooit ver weg. Goede intenties en een veelvoud aan data en richtlijnen sluiten problemen nooit volledig uit. In sommige gevallen is de noodzakelijke kennis, ervaring en techniek gewoonweg niet voorhanden. Maar zelfs als zij wel 
aanwezig zijn, dan nog spreekt het niet voor zich wat als kennis geldt, welke ervaring ertoe doet of wat als probaat middel dient. Deze aspecten zijn altijd op directe en indirecte wijze object van onderhandeling. Om complexe handelingsprocessen gaande te houden blijkt meer nodig dan enkel de aanwezigheid van kennis, ervaring en techniek. Hun toepassing is niet vanzelfsprekend maar vraagt een actieve inzet van artsen, verpleegkundigen en ouders. Hiervoor staan hun diverse stijlen van ordenen en duiden ter beschikking: redeneren en legitimeren (repertoires), spreken en interpreteren (vocabulaires) en meer of minder expliciete handelingsaanwijzingen (scripts). Mijn gebruik van 'repertoire', 'vocabulaire' en 'script' is niet vrijblijvend. Wat heeft het gebruik van deze tweede orde begrippen opgeleverd?

\section{Stijlen van ordenen}

Een analyse van de behandelingen van Esther, Tom, Robert en Maureen toont hoe de betrokkenen verschillende stijlen van ordenen gebruiken om hun kennis, ervaring en technologie op het handelingstraject in te zetten. Dankzij diverse repertoires, vocabulaires en scripts kunnen de betrokkenen onzekerheid het hoofd bieden, spanning neutraliseren, toeval en risico's opvangen en dilemma's oplossen, om zo de voortgang van het handelingsproces te waarborgen. De tweede orde begrippen bieden de mogelijkheid om verschillende stijlen van ordenen te onderscheiden en te benoemen. Wat maakt dit onderscheid op het tweede orde niveau zichtbaar?

In de eerste plaats maakt een analyse op het tweede orde niveau zichtbaar dat op het eerste orde niveau de feiten, waarden en handelingen met elkaar samenhangen. De vraag van wat het geval is en de vraag hoe juist te handelen zijn geen kwesties die los van elkaar beantwoord kunnen worden. Het antwoord op de ene vraag impliceert steeds een antwoord op de andere en omgekeerd. Met behulp van verschillende repertoires, vocabulaires en scripts komt men tot een gevalsbeschrijving, maar die reikt verder dan enkel het domein der feiten. Gevalsbeschrijvingen dragen handelingsaanwijzingen aan en hebben consequenties voor de wijze waarop men op de NICU met morele vraagstukken omgaat. Analyse van het proces waarin gevalsbeschrijvingen ontstaan, biedt inzicht in de wijze waarop morele keuzes op de NICU worden gemaakt. Dan blijkt dat de betrokkenen zowel over de interpretatie van de feiten en kansen (de prognose) als over de bepaling van de grenzen van de morele categorie (onleefbaar), tot overeenstemming moeten komen. Dit vraagt ondermeer om een afstemming tussen 'het geval' en 'de morele regel'. Hierbij kunnen verschillende soorten repertoires, vocabulaires en scripts worden ingezet. Mijn onderzoek naar deze afstemming op gevalsniveau laat zien dat in de NICU-praktijk men niet dagelijks worstelt met de tegenstellingen tussen 'algemene morele 
categorieên' en 'de bijzondere situatie van het kind', maar dat gesitueerde kennis en moraal in een en dezelfde beweging worden 'geproduceerd'.

Wanneer we het besluitvormingsproces op het eerste orde niveau van het geval onderzoeken wordt duidelijk dat er soms ook afstemming op tweede orde niveau nodig is. In de discussie over de behandeling van Esther kon men alleen maar tot besluitvorming komen door in het bijzonder het juridische en het psychosociaal vocabulaire op een lijn te brengen. Deze afstemming moet steeds opnieuw worden gemaakt. Binnen beiden vocabulaire wordt verschillend over gelijkwaardigheid gesproken en daarmee wordt ook aangegeven wie recht van spreken heeft en wie verantwoordelijk is.' Dit geldt ook voor repertoires en scripts. Een gevalsrepertoire vereist bijvoorbeeld andere argumenten dan cen situationeel repertoire. Het ene repertoire legt de grens tussen wat wel en wat niet tot de verantwoordelijkheid van de afdeling behoort op cen andere plaats dan het andere. Het gebruik van een cyclisch repertoire leidt tot een andere betekenis van het verleden, het heden en de toekomst dan het gebruik van een lineaire repertoire. Evenzeer geldt dat een script bepaalde handelingen afdwingt en hiermee sommige handelingsopties op de voorgrond plaatst en andere opties blokkeert. De verschillende manieren van redeneren, spreken en handelen interveniëren op eigen wijze in de constitutie van feiten, waarden en handelingen. Het performatieve karakter van de verschillende wijzen van ordenen geeft sturing aan de wijze waarop het handelingsproces vorm krijgt. Dit kan leiden tot fricties in het besluitvormingsproces met betrekking tot verantwoordelijkheid, wanneer iets moet gebeuren of wanneer genoeg echt genoeg is. Om zulke spanningen op te lossen, zoekt men een uitweg in het combineren van vocabulaires en spreekt men in termen van 'een dwingend advies', of men laat gedeeltelijk het script los en voegt elementen toe aan een handelingsrichtlijn of combineert repertoires en kiest voor enkel een bevestiging van het radiologisch verslag. Het situeren van kennis en moraal vraagt dan ook niet alleen een afstemming op het niveau van 'het geval' (de constructic van feiten, de robuustheid van een moreel omslagpunt of de keuze van een handelingstraject), maar ook op het niveau van repertoires, vocabulaires en scripts. De verschillende wijzen van redeneren, spreken en doen zijn dan ook zelden in zuivere vorm aan te treffen.

Gezien het belang van redeneren, spreken en handelen als constitutieve activiteiten van de NICU-praktijk verdient stijlen van ordenen aandacht. Mijn studie van de NICU-praktijk dient dan ook opgevat te worden als een poging tot exnovatie: hetgeen dat reeds in de praktijk aanwezig is, wordt op de voorgrond geplaatst en het impliciete wordt expliciet gemaakt. Meer dan innovatie doet exnovatie recht aan de creativiteit en ervaring van de betrokkenen om zich in de dynamiek van de NICU-praktijk staande te houden. Het biedt een nieuwe kijk op de eigen competentie van de NICU. Het waarborgen van de voortgang van de behandeling vraagt zowel afstemming op gevalsniveau als op metaniveau. 


\section{Reflective practitioners}

Mijn analyses in deze studie belichten niet alleen de complexiteit van handelingstrajecten en de inventiviteit van de betrokkenen, maar ook het beperkt oplossend vermogen van medische techniek en regelgeving. Soms laten ze de betrokkenen in de steek, soms niet. Maar zoals in de steek laten al impliceert: dit weten we pas achteraf. Op welke wijze laten zij de betrokkenen in de steek? Hiervoor kijk ik nog eenmaal terug op het verloop van de behandelingen van Tom en Robert.

Tom en Robert zijn allebei aan het begin van hun leven volledig afhankelijk van de inzet van medische technologie. Binnen enkele weken weet Robert zich van al deze technologie te ontdoen en wordt hij de baby waarop zijn ouders gehoopt hebben. Een baby die ze vast kunnen houden, zelf kunnen voeden, knuffelen, die slaapt zonder valium en die - nu zonder zuurstofslang in zijn keel - luidkeels huilt. Tom daarentegen, leeft zijn hele leven onlosmakelijk verbonden met de apparatuur die rond zijn couveuse staat opgesteld. Hij blijft een kind dat slaapt op valium, gevoed moet worden via een infuus of sonde en bij wie haast elke aanraking paniek veroorzaakt. Na zes maanden beademd, gevoed en verwarmd te zijn - maar ook geobserveerd, geintubeerd en geprikt - sterft Tom. De maximale inzet van zorg, kennis en technologie blijkt vergeefs en leidt hier niet tot een vol menswaardig bestaan, maar tot een kort kunstmatig leven.

De inzet van middelen heeft bij Robert leven en bij Tom lijden als resultaat. Het lijkt in deze gevallen eenvoudig om de etiketten 'juist handelen' en 'niet juist handelen' op te plakken. Maar hoe zouden we reageren als Robert het niet had gehaald, zoals veel kinderen in dezelfde situatie? We hadden dan anders gesproken en anders geoordeeld over de toepassing van de medisch-technologische mogelijkheden. Dan zouden we ons afvragen waarom de mislukte pogingen bij zijn voorgangers kennelijk onvoldoende aanleiding gaven om van zijn behandeling af te zien. Hij werd geopereerd omdat er een kans van slagen was. Maar de behandeling van Tom had eveneens een kans van slagen. Medische technologie staat dan ook nooit op zichzelf. $\mathrm{Zij}$ is niet intrinsiek goed of slecht, maar we weten pas achteraf in welke gevallen haar inzet zinvol was.

Achteraf, als het voorbij is, dan zien we duidelijk wat techniek wel en niet vermag. Vooraf is dit niet duidelijk. Vooraf ziet de situatie er anders uit. Dan werkt de belofte die iedere techniek in zich draagt nog volop. Vanuit dat perspectief zeggen we: artsen moeten hun technologisch arsenaal nog meer uitbreiden en verfijnen. Technologische ontwikkeling wordt zo het antwoord op alle vragen; met betere apparatuur verdwijnen de problemen waar artsen nu tegenaan lopen. Dit zou een valide argument zijn, ware het niet dat tegelijk met de ontwikkeling van medische technologie ook de verwachtingshorizon meeschuift. Het brengt artsen, verpleegkundigen en ouders op terreinen waar ze 
nog niet eerder zijn geweest, waar ze nog geen ervaring hebben. Technologische ontwikkeling schept niet alleen nieuwe behandelingsmogelijkheden, maar ook nieuwe vragen, nieuwe dilemma's én nieuwe tragedies. Technologische ontwikkeling zal derhalve altijd - vroeg of laat - stuiten op onzekerheid en tragiek.

Vooruitgang moeten we dus niet gelijk stellen aan reductie van problemen en onzekerheid. De korte levens van kinderen als Tom en Esther illustreren dat technologische vooruitgang zelf nieuwe (morele) problemen oproept. Deze conclusie kan geïnterpreteerd worden als een pleidooi voor een strenge regulering, voor richtlijnen die duidelijk de grenzen van behandelen aangeven en zo het 'doen of laten' op de NICU in goede banen leiden. De voorgaande analyses van situaties waarop al richtlijnen van toepassing zijn, laten echter zien dat de bestaande regels een bepaalde notie van praktijk en probleem in zich dragen en dat deze niet altijd aansluit op de concrete handelingspraktijk.

Bieden dan misschien andere, meer strengere regels van buitenaf een oplossing? Die vraag veronderstelt dat moraliteit slechts gegarandeerd kan worden als mensen eenduidig heldere regels toepassen. Mijn onderzoek legt echter een andere bron van moraliteit bloot. In de NICU-praktijk verwijst moraliteit niet zozeer naar een deductief proces van tocpassing van morele regels, maar naar een proces waarin het gaat om de afbakening van de grens van 'tot hier en niet verder'. Betekent dit nu dat de feiten de moraal dicteren en dat richtlijnen kunnen worden afgeschaft? Nee, richtlijnen spelen wel degelijk een functionele rol. Ze kunnen bijvoorbeeld tot reflectie aanzetten, de betrokkenen 'dwingen' rond de tafel te gaan zitten of ouders een stem geven. Welbeschouwd draagt dus ook een richtlijn een script. Bepaalde richtlijnen schuiven een bepaald repertoire, bijvoorbeeld een gevalsrepertoire, of een bepaald vocabulaire, zoals een juridisch vocabulaire, naar voren. Op de NICU bestaan zij naast vele anderen scripts. Sommige richtlijnen zijn strijdig met andere scripts, soms vullen zij elkaar aan en altijd zijn er bepaalde manieren van redeneren, spreken en handelen in het geding. In de interactie met andere scripts kan het gebeuren dat de grenzen van de regels nader worden gedefinieerd. Door moraliteit te situeren in het bovengenoemde afbakeningsproces wordt de tegenstelling tussen de formele wereld van de richtlijnen en de informele wereld van de dagelijkse praktijk van de NICU opgeheven. Richtlijnen spelen hun eigen rol op het handelingstraject en geven zo het praktisch handelen vorm, terwijl het praktisch handelen op haar beurt tot kennis en nieuwe richtlijnen leidt.

De vraag wie of wat de moraliteit van de afdeling bepaalt, de officiële regels of de praktijk, gaat dan ook volledig voorbij aan de manier waarop het 'algemene, formele' en het 'specifieke, informele' interacteren. Werkzame regels zijn gecodificeerde ervaringen. Richtlijnen kunnen alleen houvast bieden als ze integraal verbonden zijn met de praktijk. De komst van nieuwe medische kennis en mogelijkheden doet grenzen van handelen verschuiven. Dit impliceert dat 
richtlijnen ruimte dienen open te laten voor aanpassingen op basis van ervaringen in de praktijk. Dit betekent niet noodzakelijk dat het handelingsgebied wordt verruimd. Zo heeft onlangs één van de neonatologische centra in Nederland aangegeven dat de bestaande benedengrens voor behandelen van 24 weken zwangerschapsduur op hun afdeling weer omhoog is gebracht naar 25 weken. Niet omdat de regels dat gebieden en evenmin omdat de artsen minder technologische mogelijkheden tot hun beschikking hebben om het kind in leven te houden. Integendeel, de afdeling staat vol met apparatuur. Het is echter de ervaring die hen dat leert. Follow-up onderzoek heeft bijvoorbeeld niet alleen laten zien dat het wat uitmaakt op welke plek een bloeding in het hoofd is gelokaliseerd, maar ook wat de gevolgen zijn wanneer een zeer ernstig prematuur kind als gevolg van behandeling blijft leven. Op grond van studie, reflectie en overleg is de benedengrens verschoven. ${ }^{6}$ In vergelijking met tien jaar geleden heeft men nu meer zicht op de gevolgen van een behandeling bij premature kinderen. Op basis van deze prognostische zekerheid kan de staf als reflective practitioners 'besluiten om van behandelen af te zien ook al zijn er meer mogelijkheden om het kind in leven te houden. In de dynamiek van permanent veranderende feiten, kennis, normen en ervaring, schuift de horizon mee (en niet altijd vooruit). Zo behoudt de NICU altijd haar onzekere toekomst en blijft het voor alle stafleden ondanks hun groeiende ervaring, tasten, pionieren. $\mathrm{Zij}$ zijn inmiddels ervaren, maar ze zijn ook pioniers en zullen dat ook altijd blijven. Kortom: ervaren pioniers. 


\section{Verklarende woordenlijst}

\section{Anencefalie}

Gedeeltelijke afwezigheid van de hersenen.

\section{APGAR}

Een evaluatiesysteem van de prognose van de pasgeborene. De hartfrequentic, ademhaling, spierspanning, reactievermogen en huidskleur worden na respectievelijk één en vijf minuten na de geboorte beoordeeld. Elk onderdeel krijgt een cijfer op de schaal van 0,1 en 2 . Het systeem is vernoemd naar de Amerikaanse anesthesiste Virginia Apgar.

\section{Asfyxie}

Toestand van levensgevaar door ophouden van de ademhaling en onwaarneembare polsslag ten gevolge van onvoldoende zuurstof naar de weefsels.

\section{Attending}

Dienstdoende neonatoloog die de eindverantwoordelijkheid draagt voor de behandeling van alle kinderen op de afdeling.

Babylance

Ambulance die speciaal is ingericht voor het vervoer van pasgeborenen. Bradycardie

Abnormaal verlangzaamde hartfrequentic.

\section{Billirubine}

Galkleurstof afkomstig uit de afbraak van rode bloedlichaampjes. Broncho Pulmonair Dysplasie (BPD)

Chronische longziekte na langdurige kunstmatige beademing. BPD wordt gekenmerkt door een verhoogde ademfrequentie en afhankelijkheid van extra zuurstof. BPD komt veel voor bij langdurige beademing van kinderen die geboren zijn na een korte zwangerschapsduur c.q. met laag geboortegewicht. Continuous Positive Airway Pressure (CPAP)

Kunstmatige beademing waarbij een zuurstofverrijkt luchtmengsel wordt toegediend bij een kind dat zelfstandig ademt. Bij deze vorm van beademing wordt een continue druk in de luchtwegen aangebracht waardoor de longblaasjes niet kunnen samenvallen en de zuurstofopname optimaal blijft. 


\section{Cardiotocografie (CTG)}

Een electronische registratie van de foetale hartactiviteit en de contractie van de baarmoeder.

\section{Dismatuur}

Geboren met een te laag geboortegewicht in relatie tot de zwangerschapsduur.

\section{Doppler}

Het Dopplerapparaat brengt met behulp van ultra-geluidsgolven zowel de anatomie van het hart als de bewegingen van de hartspier en de hartkleppen in beeld. Op deze wijze kan men de bloeddoorstroom door het hart en de grote vaten bestuderen.

\section{Ductus Arteriosus Botalli}

Kanaal in het hart van een foetus waardoor het bloed van de aorta terug naar de longen stroomt. Na de geboorte sluit deze opening-de ductus - zich binnen 24 uur zodat het zuurstofrijke bloed het lichaam instroomt. Blijft deze ductus na de geboorte echter open dan stroomt het zuurstofrijke bloed terug naar de longen. Hierdoor raken de longen overvult en circuleert er te weinig zuurstofrijk bloed in het lichaam.

Elektro-Encefalogram (EEG)

Registratie van potentiaalschommelingen in de hersenen.

Embolie

Verstopping van kleine slagaderen of vaten.

\section{Intra-uteriene conditie}

De conditie van het kind in de baarmoeder (uterus).

\section{Intuberen}

Het inbrengen van de beademingsslang in de luchtpijp.

Hypoglykemie

Te laag glucosegehalte van het bloed.

Lasix

Vochtuitdrijvend middel.

\section{Neonaat}

Een pasgeboren baby tot achtentwintig dagen na de geboorte.

\section{Nurse practitioner}

Een gespecialiseerde verpleegkundige die een aantal medische taken van de arts overneemt.

Parenterale voeding

Intraveneuze voeding. Het kind krijgt via een infuus koolhydraten, eiwitten en vetten toegediend.

Perfusor

Infusor die tot op 0,1 ml per uur nauwkeurig ingesteld kan worden. 


\section{Perinatologie}

Vakgebied waarin het kind tijdens de ontwikkeling in de baarmoeder, tijdens de geboorte en in de cerste levensfase centraal staat.

\section{Prematuur}

Kind geboren na een zwangerschapsduur korter dan 37 complete weken. Resident

Arts-assistent in opleiding.

\section{Saturatiemeter}

Bepaalt de saturatiewaarden die - uitgedrukt in percentages - de hoeveelheid zuurstof aangeeft wat in het bloed circuleert.

\section{Sectio Caesarea}

Keizersnede. Verloskundige operatie waarbij het kind uit de baarmoeder wordt verwijderd.

\section{Surfactant}

Om te voorkomen dat de longblaasjes bij de uitademing dichtklappen ontwikkelen de longen surfactant, een oppervlaktespanning-verlagende stof. $\mathrm{Bij}$ premature kinderen hebben de longen nog geen surfactant ontwikkeld en dreigt het gevaar dat de longblaasjes dichtklappen. Daarom krijgen deze kinderen kunstmatige surfactant.

Syndroom van Doun

Een erfelijke aandoening waarbij het eenentwintigste chromozomenpaar een extra chromosoom heeft. Dit leidt tot aangeboren afwijkingen en mentale retardatie. Ook wel mongoloïde idiotie genoemd.

Syndroom van Turner

Abnormale lichaamsontwikkeling ten gevolge van mutatie van de genen in het geslachtschromosoom.

Thorax

Borstkas.

Trachtube

Buis voor de ademhaling na luchtpijpoperatic.

Transpositie van de grote vaten (TVG)

Hartafwijking waarbij er twee gescheiden bloedcirculaties ontstaan: de grote lichaamsslagader (aorta) komt uit de rechter hartkamer in plaats van de linker; het bloed circuleert door het lichaam en komt terug in de rechterboezem van het hart. Dit bloed bereikt nooit de longen waar het zuurstof zou kunnen opnemen. In de andere bloedcirculatic stroomt het bloed uit de linker hartkamer via de longslagader terug naar de longen waar het zuurstof opneemt en keert vervolgens terug naar de linker hartboezem. De lichaamscirculatie vindt plaats via de ductus Botalli die zijn bloed krijgt vanuit de longslagader. Wanneer na de geboorte de ductus zich sluit, zal het kind overlijden. Daarom wordt de behandeling begonnen met het open houden van 
de ductus door het toedienen van medicatie. Vervolgens wordt de afwijking operatief gecorrigeerd.

Trisomie 13 en trisomie 18

Een erfelijke aandoening waarbij het dertiende - dan wel het achttiende chromozomenpaar een extra chromosoom heeft. Dit leidt tot ernstig aangeboren afwijkingen en mentale retardatie. Kinderen met deze chromosomale afwijking worden meestal niet ouder dan een jaar.

Veneuze saturatiewaarde

Meet de zuurstof in het bloed dat naar het hart toegaat.

Zwangerschapsvergiftiging

Bij een zwangerschapsvergiftiging kan de moeder convulsies krijgen die sterk op een epileptische aanval lijken. Hierbij komt zij in een kramptoestand, waarbij zij tijdelijk het bewustzijn kan verliezen. De eerste krampaanval kan door andere gevolgd worden, waarbij het comastadium dieper wordt. Dit alles kan leiden tot hersenbloedingen, ademhalingsproblemen en hartfalen dat zowel het overlijden van moeder als kind tot gevolg kan hebben. Gezien de huidige prenatale controles en diagnostische technieken komt dit laatste nog zelden voor. 


\section{Noten}

1 In 2000 signaleerde de Gezondheidsraad een tekort aan IC-plaatsen in Nederland. De behoefte aan IC-plaatsen is sterk gestegen als gevolg van de medisch-technologische vooruitgang. Hierdoor komen kinderen die voorheen als kansloos werden gexien nu in aanmerking voor behandeling. Daarnaast zijn er demografische veranderingen, met name de stijging van het aantal buitenlandse vrouwen in Nederland en de groei van het aantal vrouwen die dankzij infertiliteitbehandeling op latere leeftijd een kind krijgen, die de behoefte aan IC-plaatsen voor pasgeborenen hebben doen toenemen (Gezondheidsraad 2000).

2 Naast de ache NICU's in academische zickenhuizen zijn er in Nederland twee NICU's in niet-academische ziekenhuizen. Op deze wijze wordt de regionale spreiding van deze voorziening gewaarborgd.

3 Kinderen die worden geboren na een zwangerschap van minder dan 32 weken of met een geboortegewicht onder de 1000 gram worden in elk geval op de NICU opgenomen.

4 In de vakliteratuur wordt soms melding gemaakt van behandeling van kinderen met een extreem laag geboortegewicht. Zoals een kind met een geboortegewicht van 440 gram (Koops 1984) of van slechts 280 gram (Muraskas, Carlson \& Halset 1991). Beiden gevallen deden zich voor in de Verenigde Staten. Ten rijde van de publicatie waren de kinderen respectievelijk 24 en 18 maanden oud.

5 Van der Veen (1996) nuanceert het gebruik van mortaliteitspercentages als indicator van de effectiviteit van de neonatologiepraktijk. Juiste interpretatie en evaluatic van sterftestatistieken vereist inzicht in de verschillende factoren die van invloed zijn op de neonatale sterfte. Voor het terugdringen van het mortaliteitspercentage onder pasgeborenen zijn doorgaans ook andere factoren verantwoordelijk. Het kan gaan om ontwikkelingen binnen de geneeskunde, zoals antibiotica, prenatale en obstetrische zorg, maar externe factoren, zoals een algehele verbetering van leefomstandigheden, voedingsgewoonten en hygiëne, kunnen eveneens een rol spelen. Daarnaast hanteren verschillende onderzoeken uiteenlopende definities en classificatieschema's. Dit maakt onderlinge vergelijking moeilijk. Tenslotte zou de evaluatie van mortaliteitspercentages altijd gerelateerd moeten zijn aan morbiditeitpercentages. Vergelijk op dit punt ook Aylward et al. (1989), Lyon (1985) en Meadow Reimshisel \& Lantos (1996).

6 Dubbelmans \& Hermans (1990).

7 Lyon (1985). De toevoeging van een asterix* verwijst naar de verklarende woordenlijst.

8 Gezondheidsraad (2000).

9 Onderzoek naar latere handicaps reikt inmiddels verder dan enkel fysieke afwijkingen. Ook emotionele, sociale handicaps en gedragseffecten, ook wel 'new 
morbidity' genoemd, worden middels follow-up onderzoek onderzocht. Een voorbeeld van onderzoek naar deze 'new morbidity' is Speechley \& Avison (1995).

In de periode $1965-1985$ daalt het aantal latere handicaps bij te vroeg geborenen van $20 \%$ naar 3\% (Grögaard et al. 1990; Koppe 1986; Verloove-Vanhorick \& Verwey 1988). Door verbeterde behandelingstechnieken geldt de toename van overlevingskansen in combinatie met een afname van latere handicaps tegenwoordig ook voor extreem kleine kinderen met een geboortegewicht onder de 1000 gram of geboren na een zwangerschap van minder dan 28 weken (Svenningsen, Björklund \& Lindroth 1997$)$.

I Versluys (1987), p.1083.

12 Zie bijvoorbeeld Dupuis, Thung \& Kerkhoff (1992) en Kuitert (1989).

13 Vrolijk, Straten \& Weijers (1991) wijzen erop dat in deze discussie zowel het rapport Meervoudige gehandicapte kinderen uit 1973 als het rapport Euthanasie bij pasgeborenen uit 1975, beiden van de Gezondheidsraad, een belangrijke rol speelden.

14 In 1973 publiceerde de Amerikaanse kinderartsen Duff en Campbell (1973) de eerste cijfers over het afzien dan wel staken van levensverlengend handelen in de neonatologiepraktijk. Een dergelijke kwantitatieve analyse werd in jaren negentig ook in Nederland uitgevoerd. Voorbeelden hiervan zijn het onderzoek van Van der Heide (1997), Kleine et al. (1993), De Leeuw et al. (1996).

15 Zie bijvoorbeeld Dupuis (1989) Leenen (1984) Molenaar (1988) en Versluys (1987). In deze discussie vormt de publicatie van Molenaar, Gill \& Dupuis (1988) over de 'Baby Ross-case' een belangrijke voedingsbodem. Zie voor een analyse van het debat over de 'Baby Ross-case' bijvoorbeeld Balk-Smit Duyzenkunst (1989), Brom (1992), Hendriks (1992: 1993). In de Verenigde Staten heeft zich in 1982 een vergelijkbare situatie voorgedaan, beter bekend als de 'Baby Doe-case'. Zie voor een uitgebreide beschrijving over deze discussic onder andere Frohock (1986) als ook Lyon (1985) en Weir (1984).

16 Voorbeelden van dergelijke publicaties zijn De Beaufort \& Dupuis (1988) Dupuis (1988), Ten Have, Kimsma \& Sauer (1990), Leenen (1988), Roscam-Abbing (1988) en Sporken (1988).

17 In 1988 verscheen de discussienota van de KNMG-Commissic Aanvaardbaarheid Levensbeeindigend Handelen, kortweg de CAL-nota genoemd, dat zich richtte op zwaar-defecte pasgeborenen. Twee jaar later presenteerde deze commissie het Interim-rapport inzake levensberindigend handelen bij wils-onbekwame patiënten. Deel t: swaar-defecte pasgeborenen. Ook de Nederlandse Vereniging voor Kindergeneeskunde (NVK) onderzocht de problematick rond levensbeèindigend handelen. In 1992 werden de resultaten gepresenteerd in het rapport Doen of Laten? Beide rapporten doen voorstellen voor criteria die als regels voor medisch handelen moeten gelden in geval van levensverlengend en levensbečindigend handelen.

Uit een vooronderzoek van de KNMG bleek dat bij het nemen van beslissingen over levensbeeindigend handelen criteria van allerlei aard een rol speelden, zoals de kans op overleving of op handicaps, de ernst van de handicap, en persoonlijke opvattingen van artsen en ouders. Van enige consensus over de criteria was nauwelijks sprake. Dit had tot gevolg dat over vergelijkbare gevallen op verschillende afdelingen uiteenlopende besluiten vielen. De Commissic Aanvaardbaarheid Levensbeêindigend Handelen (CAL) achtte enige uniformiteit in dit opzicht op zijn plaats. Om de zorgvuldigheid ten aanzien van levensbeëindigend handelen te waarborgen 
stelde de commissie verschillende regels op waar de arts zich aan kon houden. Zie CAL-rapport (1990).

19 Denk bijvoorbeeld aan medische experimenten, orgaandonatie, genetische screening. De ethische problematick die samenhangt met deze gebieden wordt onder andere beschreven in De Beaufort \& Dupuis (1988).

20 De kritiek richt zich vooral op de regelethick. Voorbeelden van regelethiek vindt men in Beauchamp \& Childress (1979) en De Beaufort \& Dupuis (1988). De regelethick gaat uit van de veronderstelling dat een arts door de toepassing van ethische principes tot een juiste beslissing kan komen. Deze procedurele benadering is echter onderwerp van kritiek, die zich met name richt op de veronderstelde relatie tussen theorie en praktijk: handelen is de toepassing van algemene theoretische principes. De onderliggende structuur van het medisch handelen wordt volgens dit model gevormd door medische principes, deductieve redeneerpatronen en besluirvormingsprotocollen. Op grond hiervan zou de regelethick voorbij gaan aan de concrete praktijk waarin de dilemma's zich voordoen. Zie voor de kritick in Nederland bijvoorbeeld Ten Have \& Kimsma (1987), Ten Have (1990; 1992), Oderwald \& Rolies (1989), De Vries (1993) en Zwart (1993; 1995).

2u. Deze empirische ethick wordt in uiteenlopende vormen tot uitdrukking gebracht. Sommigen, zoals Jonsen \& Toulmin (1988), grijpen terug op de casuistische methode waarbij de eigenheid van de situatic als punt van vertrek dient. Het accent kan ook worden gelegd op de interpersoonlijke verhoudingen en de hiermee verbonden ethiek van de zorg. Voorbeelden hiervan zijn Manschot \& Verkerk (1994) en Tronto (1993). Anderen, zoals Nussbaum (1986) bekritiseren de 'morele rekenkunde' van de normatieve ethiek en wijen in dit verband op het belang van narrativiteit. Ondanks de verschillende manieren waarop ethici de complexiteit van de morele keuze benaderen, delen zij her idee dat de particuliere ervaring van de betrokkenen het uitgangspunt van de reflectie behoort te zijn. Zie voor een overzicht DuBose, Hamel \& O'Conell (1994) en Widdershoven (2000).

22 Een kwalitatieve studie is een systematische vorm van empirisch onderzoek die zich richt op belevingen en betekenisverlening van mensen. Dergelijk onderzoek wordt vooral ingezet wanneer men inzicht wil verkrijgen in een proces of belevingsstructuur (van Zuuren 1995). Vergelijk Hak, Ten Have \& Goedhals (1992).

23 De onderzoeker kan hierbij een meer of een minder participerende dan wel observerende houding aannemen. Ikzelf heb een meer observerende rol op mij genomen. Ik miste immers de deskundigheid om in het concrete handelingsproces van artsen of verpleegkundigen te participeren. Evenmin bevond ik mij in de positie van de ouder met een kind op de NICU. Daarnaast bood de rol als 'participerend observator' mij de gelegenheid om mij vrijer over de afdeling te bewegen daar ik geen verantwoordelijkheid voor de behandeling van de kinderen droeg. Zie over de methode van participerende observatie Hammersley \& Atkinson (1983) en Seale (1998). In een vergelijkende studie naar stijlen van participerend onderzoek - semiotiek versus symbolisch interactionisme - tonen Mol en Mesman (1996) de politiek van methodologische keuzes.

24 Mijn onderzoek kan ook als een etnografische studie worden gekwalificeerd wanneer het begrip 'etnografie' als synoniem voor 'veldwerk' wordt beschouwd. Ik ben mij er echter van bewust dat het begrip 'etnografie' niet eenduidig is en er binnen verschillende vakgebieden een meer of minder theoretisch en politicke lading aan verbonden wordt (denk bijv. aan de 'reflexive turn'). Een gebruik van het begrip 
'etnografie' zou bij lezers bijvoorbeeld de verwachting kunnen wekken dat de onderzoeker als verteller expliciet in de tekst aanwezig zal zijn en/of zal reflecteren op de invloed van haar aanwerigheid in de onderzochte praktijk. Mijn onderzoek moet echter niet als een louter inductieve onderneming worden gezien. Het begrip 'etnografie' kan deze associatic oproepen. De inzet van dit onderzoek is niet 'het leven op de NICU' te beschrijven, maar een antwoord te formuleren op de vraag: hoe slaagt men er in snel en adequaat te handelen in situaties van onzekerheid en twijfel, situaties die men - gegeven de onderzoekssetting - ook nog zelf opzockt. In mijn analyse spelen theoretische concepten een grote rol. Dit onderzoek zou daarom bij wijze van spreken een 'theoriegericht etnografie' genoemd kunnen worden. Voorbeelden van studies in de gezondheidszorg die zich wel (terecht) als etnografie afficheren zijn Pool (1996), The (1997; 1999a) en Vermeulen (2001). Deze studies zijn er wel op gericht om de 'normale' gang van zaken te beschrijven en te verklaren. Ook in deze studies wordt echter gesuggereerd dat het ene ware verhaal over de praktijk niet bestaat en dat er altijd meerdere verhalen te vertellen zijn.

25 Hierin komt de NICU overeen met andere afdelingen in de gezondheidszorg zoals bijvoorbeeld de volwassen IC, de EHBO en de afdeling 'acute opname' in de psychiatrie.

26 De voorkeur voor 'geneeskunde-in-actie', past in de traditie van het moderne wetenschaps- en techniekstudies naar 'wetenschap-in-actie' zoals die vanaf de jaren zeventig worden verricht. Dit neemt niet weg dat een microanalyse van praktijken evenzeer centraal staat binnen andere vakgebieden zoals (medische) sociologie en antropologic. Het wetenschaps-en techniekonderzoek maakt dan ook dankbaar gebruik van de reeds bestaande inzichten in deze vakgebieden. Ook andersom is er een tendens waar te nemen. Er bestaat een groeiende samenwerking tussen de medische antropologie en het wetenschaps- en techniekonderzoek. Zie hierover Capers \& Koenig (1996), Franklin (1996), Kaufert \& Kaufert (1996), Layne (1998). Deze tendens is ook zichtbaar tussen de medische sociologic en het wetenschaps- en technickonderzock. Zie Bartley (1990), Bury (1986), Casper \& Berg (1995), King (1987), Lock \& Gordon (1988), Nicolson \& McLaughlin (1988), Wright \& Treacher (1982).

27 Bekende voorbeelden hiervan binnen het wetenschaps en techniekonderzoek zijn de studies Collins (1989), Knorr-Cetina (1981), Latour \& Woolgar (1979) en Traweek (1988).

$28 \mathrm{Ik}$ volg hierin de kwalificatie zoals deze ook binnen de ethick zelf wordt gehanteerd. Hierin worden etnografische studies als een belangrijke, doch slechts eerste stap gezien. Etnografische studies beschrijven op welke manier men handelt, maar kunnen zelf geen uitspraak doen over de wijze waarop men behoort te handelen. Om het predikaat 'normatieve etnografie' te krijgen onderscheidt de ethicus Ten Have vier stappen. Ten eerste, etnografisch onderzoek naar de interne moraliteit van de (medische) praktijk. Ten tweede, een sociologische analyse van de maatschappelijke waarden en normen ten aanzien van medisch-ethische thema's. Ten derde, de ontwikkeling van een nieuw theoretisch perspectief te aanzien van de gezondheidszorgpraktijk. Ten vierde tenslotte, een nieuwe conceptualisering van bio-ethiek waarmee de interactie tussen de interne en externe moraliteit (zoals onderzocht in stap een en twee) kan worden verklaard (Ten Have \& Lelie 1998). Zie voor een discussic over de relevantic van etnografisch onderzoek voor de ethick ook Arnold \& Forrow (1993), Brody (1993), Pearlman, Miles \& Arnold (1993) en Pellegrino (1995).

29 Steeds meer wordt medische ethiek object van onderzoek van sociologische en antropologische studies. Zie bijvoorbeeld DeVries and Subedi (1998) en Weisz 
(1990) en Muller (1994) en Schermer (2001). Zie voor een bespreking van verschillende etnografische studies in relatie tot medische ethiek Crigger (1995).

Welbeschouwd bestaat dé Verenigde Staten in dit verband niet. Onderzoek gedurende een andere maand met een andere neonatoloog als verantwoordelijke attending, of in een ander ziekenhuis in een Amerikaanse staat met een andere wetgeving, kan een ander beeld geven. In Nederland zijn de onderlinge verschillen tussen de neonatologieafdelingen op het gebied van medisch-technologische voorzicningen, patièntenpopulatie en behandelingsbeleid (nog) gering (Gezondheidsraad 2000; Nederlandse Vereniging voor Kindergeneeskunde 1992).

31 Dit wil niet zeggen dat de onderlinge variaties tussen de twee afdelingen geheel zijn terug te voeren op culturele verschillen. Elke medische context kent zijn eigen specifieke praktische orde.

32 Door dit selectiecriterium wordt wellicht het clichebeeld van 'Amerikaanse tocstanden' onbedoeld bevestigd. Daarom wil ik er nogmaals op wijzen dat mijn beschrijving zich vooral richt op probleemsituaties om inzicht te krijgen op de wijze waarop het handelen voortgang vindt.

33 Als aanvulling op de dagelijkse gesprekken die ik ter plaatse met de betrokkenen heb gevoerd, heb ik vijf artsen en negen verpleegkundigen geinterviewd.

34 In het bijzonder studies over de NICU, zoals het onderzoek van Anspach (1993), Frohock (1986), Guillemin \& Holmstrom (1986) en Schlomann (1994). Opgemerkt dient te worden dat de publicatie van Eric Vermeulen (2001) over neonatologie helaas na de voltooïing van mijn onderzoek verscheen. Hierdoor krijgt het in mijn studie niet de aandacht die het verdient. Ook etnografische studies over andere praktijken binnen de geneeskunde bevatten voor mijn onderzoek waardevolle inzichten, in het bijzonder de studies van Bosk (1979; 1980), Strauss et al. (1985) en Zussman (1992). Voor het verzamelen van veldmateriaal heb ik een logboek aangelegd. Naast schriftelijke notities heb ik ook met behulp van een geluidsrecorder data vastgelegd. Op de NICU van het Academisch Centrum was het gebruik van de recorder zonder enige beperking toegestaan. Hierbij heb ik mij geconcentreerd op zowel formele als informele overlegsituaties op de afdeling. Daarnaast werd de geluidsrecorder ook gebruikt bij het afnemen van interviews. In het Northeastern General Hospital mocht ik deze opname recorder alleen voor interviewdoeleinden inzetten. Bij mijn dataverzameling heb ik ook gebruik mogen maken van een videorecorder waarmee ik overlegsituaties, handelingen en de inrichting van de NICU kon opnemen. Dit medium heeft mij de mogelijkheid geboden om zowel non-verbale communicatie als ook bewegingspatronen in overleg en handelingen op beeld vast te leggen. De videorecorder heb ik echter pas in de laatste weken van mijn verblijf in het Academisch Centrum ingezet. Het gebruik van een videorecorder kan namelijk het opbouwen van een relatie met de groep in de weg staan doordat de recorder heel concreet tussen de onderzoeker en de groepsleden in staat. Opgemerkt dient te worden dat het gebruik van een videorecorder in het Northeastern General Hospital niet was toegestaan. Evenmin had de ethische commissic van dit ziekenhuis mij toestemming verleend om enig contact met ouders te hebben. I k zou ouders er onbedoeld toe kunnen aanzetten om juridische stappen tegen de afdeling te ondernemen, aldus de commissie.

36 Binnen de antropologie geldt dit niet alleen als methodologisch probleem, maar wordt ook de emotionele belasting van de onderzoeker erkend. Zie over dit laatste 
punt Bosk (1992), Cannon (1989), Katz Rothman (1986), Shaffir \& Stebbins (1991) en The (1992; 1999b).

37 Met het gebruik van een 'passive voice' wil ik niet de indruk wekken dat mijn verslag het enige verhaal is dat over de NICU verteld kan worden. Binnen de traditic van kwalitarief onderzoek is het idee dat elke tekst de subjectiviteit van de auteur in zich draagt, reeds gemeengoed. Deze erkenning van de 'handtekening' van de auteur maakt een explicitering van deze subjectiviteit door het gebruik van een 'active voice', daarom niet meer noodzakelijk. Zie Geertz (1988).

\section{PASGEBOREN EN ONBEPAALD}

1 Tijmstra (1987) spreekt in dit verband over het imperatieve karakter van technologie als gevolg van 'de geanticipeerde beslissingsspijt'. Hiermee wordt bedoeld dat een afwijzing van de technologische mogelijkheden betekent dat men een kans op een positieve uitkomst laat lopen en dat men hier later spijt van kan krijgen. Men kiest voor de inzet van technologie om deze mogelijke spijtgevoelens te voorkomen. De geanticipeerde beslissingsspijt zou volgens Tijmstra verklaren waarom men het aanbod van medische technologie nauwelijks kan afwijzen en het aldus een dwingend karakter krijgt.

2 In het Northeastern General Hospital wordt er direct na de geboorte ook een voetafdruk van het kind gemaakt en krijgt het een naambandje om de pols. Met deze maatregelen tracht men een mogelijke verwisseling van de kinderen en andere vergissingen te voorkomen.

3 Het belang van het geslacht wordt pijnlijk duidelijk op het moment dat niet direct kan worden vastgesteld of het om een jongetje of een meisje gaat. In geval van tweeslachtigheid missen ouders en andere betrokkenen een belangrijk fundament om zich tot het kind te kunnen verhouden. Wanneer niet duidelijk is of een kind een jongen of een meisje is lijkt het identificatieproces te stokken. Een goed DNA-onderzoek neemt enkele dagen in beslag. Tot die tijd verblijft het kind in een hybridisch niemandsland en valt een groot deel van het geboorteritueel stil. De aangifte bij de gemeente moet worden uitgesteld en de geboortekaartjes worden nog niet gedrukt.

4 De stethoscoop die op deze afdeling wordt gebruikt is kleiner dan de standaardmaat.

5 Wanneer de zuurstofslang te diep is ingebracht passeert het de vertakking van de luchtpijp naar de rechter- en linkerlong. Dit betekent dat als de zuurstofslang de rechterpijp ingaat het alleen één long beademt en de linkerlong dichtklapt.

6 Gezien de heterogene aard van de elementen die betrokken zijn in het ordeningsproces is er veeleer sprake van een sociotechnisch ordeningproces. Vergelijk het begrip 'heterogeneous engineering' (Bijker \& Law 1992).

7 'An ordering centre is (probably) constituted by gathering, symplifying, representing, making calculations about, and acting upon the flow of immutable mobiles coming in from and departing for the periphery.' (Law 1994, p.ro4) 'Immutable mobiles' zijn objecten die verplaatst en gecombineerd kunnen worden zonder dat ze uireenvallen, bederven of veranderen. Bijvoorbeeld teksten, kaarten, tabellen, afbeeldingen, diagrammen, formules, schema's (Latour 1987, p.227). Het begrip 'ordering centre' van Law vertoont grote gelijkenis met het begrip 'centres of calculation' zoals dit wordt gebruikt door Latour (1987), p.232.

8 Vergelijk ook Berg (1996). 
9 Law (1994), p.26.

10 Deze term ontleen ik aan Kuhn (1962).

II Het zou een misvatting zijn om te denken dat er volledige orde zou kunnen bestaan. Er is eerder sprake van ordening, voortdurende ordening. '(...) orders are never complete. Instead they are more or less precarious and partial accomplishments that may be overturned. They are in short, better seen as verbs rather than nouns. '(Law 1994. p.r). Het is daarom meer op zijn plats om het proces van ordening te onderzoeken, dan de orde zelf. Orde en ordeningsprocessen zijn belangrijke thema's binnen de sociologic. Met name microsociologisch georiënteerde stromingen zoals ethnomethodologie richten zich op het daadwerkelijke ordeningsproces. Kort gezcgd richt de ethnomethodologie zich op de alledaagse regels, de recepten waarmee mensen hun dagelijks leven organiseren. Garfinkel (1967) en Lynch, Livingston \& Garfinkel (1983) zijn voorbeelden van ethnomethodologische studies, waarbij laatstgenoemde zich op wetenschapspraktijken richt.

12 Als we niet van zo'n wisselwerking uitgaan, vervallen we in een sociaaldeterministische visie.

13 Zie ook Rees (1981).

14 Vergelijk het begrip 'centre of coordination' van Garfinkel (1967).

15. Het gebruik van de status betekent echter meer dan de structurering van de handelingspraktijk. Het dossier biedt aan bepaalde informatie meer ruimte dan aan andere en geeft aan de arts een centrale plaats in de informatievoorziening. Er ontstaat hiermee een politisering van de afdelingsbureaucratie ten gunste van artsen. Zie ook Berg (1996) en Heath (1982).

16 Heath (1982), p.59.

17 In de literatuur verwijzen veel begrippen naar het proces van ordenen. Zoals 'taalspel' (Wirtgenstein 1958), 'paradigma' (Kuhn 1962), 'framework' (Goffman 1974), 'styles of reasoning' (Hacking 1992), 'modes of ordering' (Law 1994) en 'logics' (Mol and Berg 1994). Ik gebruik het begrip 'repertoire' waarbij het accent ligt op de stijl van redeneren als manier van ordenen. Zie voor het gebruik van dit begrip ook Bal (1998), Gilbert \& Mulkay (1984), Mol (1997), Rip (1995) en De Wilde (1998).

I8 Tegelijkertijd refereert hij aan 'de gemiddelde radioloog' om 'de ander' een gezicht te geven. Het gebruik van 'de ander' als contrast van 'zelf is een belangrijk middel om een eigen domein af te bakenen. Dit geldt ook voor de discussie met betrekking tot de rol van de ouders. Zie hoofdstuk 3 Reisgenoten. Vergelijk op dit punt Michael (1996).

19 In dit geval wijzen 'drie' en 'vier' naar de ernst van de hersenbloeding: graad drie of graad vier, waarbij de laatste de zwaarste categoric is.

20 Amann en Knorr-Cetina (1989) benadrukken het belang van spreken voor (wetenschappelijke) denkprocessen. Er zou sprake zijn van 'thinking through talk'. Vergelijk ook het begrip "narrative reasoning' van Mattingly (1998).

21 Zie Goodman and Elgin (1987) en De Wilde (1997).

22 Hacking (1992) en Michael (1996) richten zich expliciet op de rol van de dingen in dergelijke constructieprocessen. 
1. Onderzoek naar neonaten beperkt zich dan ook niet tot de situatie van pasgeborenen. Ook ouders zijn onderwerp van onderzoek. Aandachtspunten hierin zijn bijvoorbeeld stressfactoren voor ouders (Seideman et al.1997; Shields-Poë \& Pinelli 1997); de communicatie tussen staf en ouders (Bogdan, Brown \& Bannerman Foster 1982); het emotionele proces van ouders met een kind op de NICU (Honig Bachman and Furlong Lind 1997; Koppe 1989; De Leeuw \& Bakker 1995) en de positie van ouders in het besluitvormingsproces (van der Heide van der et al. 1998).

2 De aanwezigheid van twee aparte sluizen voor ouders en stafleden vormt en reflecteert de sociale orde van de afdeling. Sociale onderscheidingen komen zo tot uitdrukking in de architectuur van de afdeling.

3 Naaste familie en vrienden mogen alleen in aanwezigheid van ouders de afdeling betreden.

4 Voor die stafleden die de gehele dag op de afdeling doorbrengen geldt het tegenovergestelde. Zij trekken bij het tussentijds verlaten van de afdeling een witte jas over hun uniform aan.

5 De sluis is niet waterdicht. Sommigen bacterièn weten de weg naar binnen te vinden. Daarom moet men bij het betreden van de units opnieuw de handen wassen. In het Academisch Centrum komen de ouders de afdeling binnen via een aparte 'oudersluis', De staf heeft een eigen sluis en komt doorgaans nooit in de oudersluis.

6 Als het enige tijd voor de bevalling al duidelijk is dat het kind moet worden opgenomen, worden ouders van tevoren rondgeleid op de afdeling. De ervaring leert dat de afdeling dan als minder beangstigend wordt ervaren. Bovendien geeft informatie over de zorg en behandeling ouders hoop over de prognose van hun kind. Onderzoek heeft uitgewezen dat een dergelijke voorbereiding de angstgevoelens van ouders reduceert (Griffin et al. 1997). Een dergelijke voorbereiding is echter niet altijd mogelijk, want het is in de meeste gevallen niet van tevoren bekend dat de zwangerschap op de afdeling zal eindigen.

7 Omwille van de leesbaarheid worden in dit hoofdstuk ouders en stafleden voornamelijk als categorieèn benaderd.

8 Vergelijk Anspach (1993).

9 Zie over het onderscheid dat stafleden maken in hun verwachtingen ten aanzien van vaders en moeders de studie van Heimer \& Staffen (1995).

10 Uit onderzoek naar de labelingspraktijk van een NICU van komt naar voren dat het gedrag van ouders uit lagere sociale klassen milder wordt beoordeeld dan hetzelfde gedrag van ouders uit hogere sociale klassen (Heimer \& Staffen 1995).

II Deze voorbeelden heb ik ontleend aan Guillemin \& Holmstrom (1986), p.178.

12 Anspach (1987) wijst op de beperkingen van telefonisch contact. Zoals het ontbreken van non-verbale signalen, privacy en het feit dat er slechts twee sprekers - de arts en één van de ouders - actief aan het gesprek kunnen deelnemen. Gezien het belang en de emotionele lading van veel beslissingen schiet een telefonisch gesprek soms tekort als het gaat om de juiste opvang van ouders. Bovendien kan het tot misverstanden leiden die niet direct door de staf worden opgemerkt.

13 lk wil er nogmaals op wijzen dat deze voorbeelden niet representatief zijn voor het contact tussen ouders en staf. In de meeste gevallen is er sprake van een goede relatic. 
14 Bogdan et al. (1982) beschrijft in dit verband hoe stafleden ouders proberen te beschermen door het gebruik van eufemisme. De communicatie russen staf en patiènt of familie over slecht nieuws is een belangrijk object van onderzoek binnen de medisch sociologie. Zie in dit verband bijvoorbeeld Taylor (1984) en The (1999a).

15 Een breuk kan zich op verschillende manieren voordoen. De ouders kunnen bijvoorbeeld de behandeling van het kind ongewenst achten en weigeren hun toestemming te geven. Wanneer de staf deze keuze niet gerechtvardigd acht en het besluit neemt het kind wel te behandelen, kunnen ouders (tijdelijk) uit de ouderlijke macht ontzet worden. Ouders zijn op dat moment het woordvoerderschap over hun kind kwijt. In een ander scenario wordt de band tussen ouder en staf verbroken door ouders die hun kind meenemen naar een ander ziekenhuis. In een enkel geval laten ouders hun kind gewoon in het ziekenhuis achter. In het Northeastern werd een kind dat was geboren na zevenentwintig weken zwangerschap en verschillende aandoeningen had door zijn ouders verlaten. $\mathrm{Zij}$ wilden er niets mee te maken hebben. Een van de verpleegkundigen heeft vervolgens dit kind geadopteerd. Dit soort situaties zijn extreem en gelukkig een hoge uitzondering.

16 Zie hoofdstuk 2 Pasgeboren en onbepaald.

17 Ik onderzock vocabulaires vanuit een pragmatische benadering. Binnen die benadering wordt taal als een element van de handelingscontext beschouwd. Op deze manier verwijst taal niet zozeer naar een reeds bestaande werkelijkheid, maar krijgt de werkelijkheid vorm in het gebruik van taal. Met het gebruik van een vocabulaire wordt een bepaalde werkelijkheid gecreckerd. Met een ander vocabulaire scheppen we een andere versic van de wereld (Goodman 1978). Zie ook De Wilde (1992), p.226 e.v.

18 Ik gebruik hier het begrip 'vocabulaire' en niet 'perspectief omdat dat laatste impliciet veronderstelt dat er slechts één werkelijkheid is, waarnaar vanuit verschillende invalshoeken gekeken kan worden: het pragmatisme benadrukt dat er verschillende werkelijkheden zijn. Zie De Wilde (1987).

19 Vocabulaires hebben een collectief karakter. Vergelijk het begrip 'taalspel' van Wittgenstein (1958). De betekenis van woorden, aldus Wittgenstein, wordt niet bepaald door de objecten waaraan zij refereren, maar ligt besloten in hun gebruik binnen een taalspel. De regels van het taalspel leggen de betekenis van woorden vast.

20 De Franse filosofen Luc Boltanski en Laurent Thévenot hebben dit idee uitgewerkt in een beschrijving van zeven verschillende domeinen - zoals het huiselijke rijk, het rijk van faam, het rijk van burgerschap - met bijpassende mensen, dingen en handelingen. Zie voor een inleiding op hun werk de Recht \& Co (1992). Voorbeelden van onderzock binnen de gezondheidszorg naar de wijze waarop verschil en/of verschuiving in taalgebruik een specifieke gezondheidszorgpraktijk creèert zijn Van der Lyke (2000), Mol \& Van Lieshout (1989) en Mol (1997).

21 Hierbij dient te worden opgemerkt dat er ook in andere vocabulaires over ouders op de afdeling gesproken zou kunnen worden. Zoals bijvoorbeeld een economisch vocabulaire, waarin de ouder als consument van het gezondheidszorgsysteem naar voren komt. Of een vocabulaire waarin de mannelijkheid en vrouwelijkheid van ouders voorop staat. Ik beperk mij echter tot het juridisch en psychosociale vocabulaire. Hierbij wil ik opmerken dat de wijze waarop er over ouders gesproken wordt niet statisch is. Dit hangt onder andere samen met de veranderingen in de conditie van het kind. Het juridisch vocabulaire dient zich meestal pas aan wanneer een behandeling wordt gestaakt. 
22 Michael (1996) pleit ervoor om ook de herkomst van vocabulaires te onderzoeken. 'Often the impression one is left with is that these constitutive resources float around in some linguistic or discursive or cultural ether. The point is that these are specifically embodied in particular textual and representational forms, realized in specific and particular social contexts or patterns of social contexts' (p.r2).

23 In verschillende psychologische theorieèn en onderzoeken wordt gewezen op de noodzaak van het ouder/kind contact direct na de geboorte. Bekend zijn in dit verband de zogenaamde 'Harlow-aapjes', een onderzoek waarin de Amerikaanse psychologen Harlow en Suomi via experimenten aantonen dat babyaapjes een veilige, zachte omgeving verkiezen boven voedsel. Met betrekking tot mensen is dit onder meer uitgewerkt door Bowlby (1971) in zijn 'theory of bonding'. Onderzoek naar de implicaties van de opname van pasgeborenen in een ziekenhuis neemt veelal de bindingtheoric als uitgangspunt. Zie bijvoorbeeld Klaus \& Kennel (1970), De Leeuw, Cuttini \& Reid (1993) en Rode (1981). Naast de ruime bezoekuren op de NICU is ook de aanwezigheid van een Ronald McDonald Huis geënt op de 'theory of bonding'. In deze woonvoorziening kunnen ouders logeren wanneer hun kind in het ziekenhuis is opgenomen. Op deze wijze blijven zij in de nabijheid van hun zieke kind.

24 In Nederland is de toekenning van NICU's sinds 1983 geregeld in het Besluit Bijzondere Functies Wet Ziekenhuisvoorzieningen. Op grond van het cerste artikel van dit Besluit mag een ziekenhuis alleen intensive care voor pasgeborenen leveren als zij hiervoor een vergunning van de minister van Volksgezondheid heeft gekregen. Op deze wijze wordt het spreidingsbeleid en de beheersing van intensieve zorg voor pasgeborenen door de overheid gestuurd. Als gevolg van plaatsgebrek of personeelstekort kan het voorkomen dat de moeder en het kind niet in hetzelfde ziekenhuis verblijven of dat een tweeling niet op dezelfde NICU kan worden opgenomen. Hoewel de betrokken ziekenhuizen de mogelijkheid van overplaatsing van moeder of kind voorop stellen, kan het in dergelijke gevallen dagen duren eer de moeder haar kind (terug)ziet. Overplaatsing kan alleen als de lichamelijke conditie van moeder of kind dat toelaat.

25 Vergelijk Dubbelman \& Hermans (1990), Koppe (1989) en De Leeuw \& Bakker (1995).

26 Hierin verschillen verpleegkundigen niet van artsen. Ook de eerder beschreven frustratie van de arts-assistent die aangaf dat je "niet eventjes met ouders spreekt", kan ook als een voorbeeld gelezen worden waarin de staf tegen een toenemende werkdruk aanloopt die ten koste gaat van het contact met ouders. Zie paragraaf $\mathrm{I}$ van dit hoofdstuk.

27 "The "illness" of parents is essentially social rather than biological, the opposite of the illness of the infant, which is purely biological and without interactive dimensions. The nurses aided by social workers and psychologists, take major responsibility for treating the parents as second order of patient, that is, as psychological case. (Guillemin \& Holmstrom 1986, p.175, mijn cursivering).

28 Anspach (1993) wijst erop dat de status van informatie over ouders veel lager is dan de status van medische informatie over het kind.

29 Anspach (1993) omschrijft dit als 'a work force that functions to evaluate and manage parents' attachment to their babies' (p.144).

30 Anspach (1993), p.u2.

31 Carson (1996) wijst op een toename van 'social complexe gezinnen' in Amerikaanse neonatologieafdelingen als gevolg van drugsgebruik, tienerouderschap, analfabetisme, armoede, AIDS en agressie. Op de meeste NICU's is de organisarie van omgang en opvang van ouders echter gebaseerd op 'de competente ouder' die informatie begrijpt, 
deelneemt an het beshuivormingsproces en in staat is om de verantwoordelijkheid voor het kind te dragen na ontslag. De psychosociale problematiek die complexe gezinssituaties met zich meebrengen stelt de staf voor nieuwe dilemma's en problemen. Carson pleit voor een grotere betrokkenheid van de sociaal werker in de opvang en nazorg van ouders. Zie ook Bell (1997) en Honig Bachman \& Furlong Lind (1997).

32 Guillemin \& Holmstrom (1986).

33 'Passend' wordt hier in de actieve vorm gebruikt: een bepaalde uitspraak en zijn specifieke context passend maken. Vergelijk Goodman and Elgin (1987).

34 Anspach (1993), p.148.

35. Anspach (1993) geeft aan dat ouders met een laag opleidingsniveau in mindere mate bij de besluitvorming worden betrokken. Zelf heb ik dit verschijnsel niet aangetroffen, noch in het Academisch Centrum, noch in het Northeastern General Hospital. De mate waarin en de wijze waarop ouders hier aan de besluitvorming deelnamen, had meer te maken met het feit of de staf het gevoel had dat ze contact kregen met de ouders van een kind en hoeft dus niet met opleidingsniveau samen te hangen.

36 Anspach (1993) wijst op het effect van de automatisering van het vergaren en verwerken van gegevens. Het zou een ongelijke verdeling van informatic in de hand werken. De staf heeft directe toegang tot de informatie. Ouders zijn enkel ontvangers van informatic. $\mathrm{Zij}$ hebben zelden informatic over hun kind die de staf nog niet heeft. Ze lopen op deere manier altijd een stap achter. Volgens Anspach zou deze in. formatieverdeling de ouder in een ongelijke positie in her beslissingsproces plaatsen. Verschillende onderzoeken hebben laten zien dat deze regeling in de praktijk anders uitwerkt. Hoewel 'informed consent' op het eerste gezicht een regeling lijkt die ouders duidelijk een plaats geeft in het besluirvormingsproces, betekent dit nog niet dat elke ouder zichzelf ook daadwerkelijk als partij in de besluitvorming beschouwt. Onderzock in de Verenigde Staten onder ouders van kinderen op de NICU gaf aan dat ouders veelal wel het gevoel hebben dat ze over beslissingen worden geïnformeerd (informed), maar niet dat ze bij de besluitvorming betrokken worden (Raines 1996). Dit wil echter niet zeggen dat elke ouder dit betreurt. Sommige ouders geven te kennen dat ze blij zijn dat anderen deze taak op zich nemen. Vergelijk Pols \& Mol (1994) en Schlomann (1994).

38 Onderzoek naar de inbreng van ouders in de besluitvorming rond levensbeèindigend handelen in Nederland laat zien dat ouders in hoge mate bij de besluitvorming betrokken zijn. In verreweg de meeste gevallen was het besluit om een behandeling te staken gebaseerd op overeenstemming tussen artsen en ouders. In een enkel geval was er sprake van dissensus. In situaties waarin ouders voorstander waren van het continueren van de behandeling, werd aan dit verzoek toegegeven. In uitzonderlijke gevallen kwam de dissensus voort uit het verzoek van ouders de behandeling te staken en de weigering van artsen om aan dit verzoek tegemoet te komen. In deze gevallen was de keuze van de medische staf doorslaggevend en werd de behandeling gecontinueerd. De onderzoekers concluderen dat bij onenigheid de mening van ouders doorslaggevend is, mits zij in de positie zitten die continuering van de behandeling voorop stelt (van der Heide et al. 1998).

39 Stolker (1989) noemt hiervoor verschillende redenen. Zo worden patiěnten, in dit geval de ouders van kinderen op de NICU, door advocaten benaderd (de zgn. 'ambulance-chasers') met het aanbod om hen bij te staan in een juridisch proces tegen een arts of ziekenhuis. In de Verenigde Staten werken advocaten volgens 
het principe van 'no cure, no pay', waardoor de financiële risico's van de eiser kleiner zijn dan in Nederland.

40 Zie hoofdstuk 1 Neonatologie: een praktijk in beweging.

41 Men spreekt in dit verband ook wel over 'defensive medicine'. Het medisch handelen is dan meer gericht op het versterken van de eigen juridische positie, dan dat het geleid wordt door de medische conditie van het kind. Dir betekent nog niet dat dergelijk handelen naar medische maatstaven van ondeugdelijke kwaliteit is (Stolker 1989).

42 Een dergelijk bestuit is uitzonderlijk. Onderzoek in de Verenigde Staten onder NICUverpleegkundigen wijst erop dat deze doorgaans altijd de orders van artsen uitvoeren, ongeacht hun eigen standpunt in het behandelingsbeleid (Raines 1996). Voor etnografisch onderzoek naar de rol van verpleegkundigen in het besluitvormingsproces rond levensbeéindigend handelen bij volwassen patiënten (euthanasie), zie The (1997).

43 Vergelijk Guillemin \& Holmstrom (1986).

44 Anspach (1993) omschrijft de eerste positic als het assent model, waarin ouders instemmen met de keuze die de staf reeds heeft gemaakt, en de tweede positie als het informed consent model, waarin ouders als actieve participanten aan de besluitvorming deelnemen ( $p .87)$.

\section{EEN ONZEKER TRAJECT}

I De studie Training for Uncertainty van Fox (1957) vormt het begin van een recks medischsociologische studies van het thema 'onzekerheid bij artsen'. Zie ook de studies van Atkinson (1984) Bosk (1979; 1980) Fox $(1988 ; 2000)$ Hunter (1991) Katz (1984) Light (1979) en Zussman (1992). In deze literatuur worden verschillende bronnen van onzekerheid onderscheiden. De eerste komt voort uit het gebrek aan kennis bij de arts, die nooit het gehele medische kennisdomein paraat kan hebben. Daarnaast kent ook de medische kennis haar grenzen. In sommige gebieden tast de geneeskunde nog volledig in het duister. Het is aan de arts om te bepalen of zijn onzekerheid een persoonlijke of professionele grond heeft, en dit is zelf weer een bron van onzekerheid. Dit onderscheid tussen een onzekere wereld en onzekere kennis over die wereld is in strijd met de constructivistische kennisopvatting die ik in dit boek hanteer. In die opvatting heeft het geen zin om anders over de situatie van de patiënt te spreken dan in termen van de kennis die we over die situatie hebben. Er zijn dus geen medische situaties die intrinsiek onzekerder zijn dan andere situaties; er zijn wel situaties waarover artsen minder weten en die daardoor minder voorspelbaar zijn. Zie hoofdstuk 1 voor een introductie van het constructivistische kennisbeeld.

2 Gezien deze specificiteit van de individuele gevallen, geldt voor de arts de patiënt als uitgangspunt van handelen. Dit maakt geneeskunde tot 'a science of individuals' (Hunter 1991, p.28).

3 Bosk (1980).

4 Vergelijk Atkinson (1984) en Katz (1984).

5 Het gebruik van de term 'traject' is overeenkomstig aan 'trajectory' zoals geformuleerd door Anselm Strauss. Trajectory verwijst naar de ontwikkeling van de zickte, het werk dat in relatic tot deze ontwikkeling verricht moet worden, alsook de invloed van dit werk op diegenen die deze activiteiten uitvoeren (Strauss et al. 1985, p.8).

6 De keuze tussen 'doen of laten' na de geboorte is reeds in hoofdstuk 2 Pargeboren en onbepaald besproken. 
7 Op dit punt bezit de staf veelal slechts informatic over het verloop van de awangerschap en de bevalling.

8 Hunter (1991).

9 Strauss et al. (1985).

to Vergelijk het begrip 'trajectory scheme' van Strauss et al. (1985) p.26 c.v.

II Zie hoofdstuk 2 Pasgeboren en onbepaald.

12 Als cen arts besluit van behandelen af te zien, loopt hij het risico dat hij een kind lat sterven dat wel een kans op overleven heeft. Besluit hij een kind wel te behandelen, dan loopt hij het risico dat het kind een bestaan zonder kwaliteit van leven tegemoet gaat. Zie over deze problematick ook Frohock (1986) Guillemin \& Holmstrom (1986) Strauss et al. (1985) en Zussman (1992).

13 In het Northeastern General Hospital werd hiervoor de uitdrukking "in, usait and see" gebruikt.

14 Bosk (1980) beschrijft verschillende rituelen die tijdens de visite worden gevolgd om met twijfel om te gaan.

15 De beschrijving van een protocol ontleen ik aan Berg (1998).

16 Behandelingsprotocollen zijn gericht op standaardisering van medisch handelen. Deze doelstelling staat op gespannen voet met de specificiteit van de situatie waarin het handelen plaatsvindt. Zie Berg (1997b) voor een uitgebreide kritick op de veronderstelde rationaliteit van protocollen en andere besluitvormingsondersteunende instrumenten.

17 Guillemin \& Holmstrom (1986).

18 Andere punten van kritick zijn bijvoorbeeld dat dit instrument het medisch handelen zou reduceren tot 'kookbock-geneeskunde' en tot 'deskilling' zou leiden; dat de aard van protocollen (generiek) een andere is dan de aard van het praktisch medisch handelen (individueel) en dat zij zo cen vertaalslag noodzakelijk maken; en dat de normatieve aspecten van protocollen verhuld blijven alsof het neutrale instrumenten zijn. Protocollen suggereren dat medische data uit heldere stukjes informatie bestaan; dat medische criteria duidelijk omschreven regels zijn die enkel toegepast te hoeven worden; en dat medisch handelen bestaat uit opeenvolgende stappen (Berg 1997a; 1998).

I9 Hoewel in de literatuur de begrippen 'protocol', 'standaard' en 'richtlijn' door elkaar heen worden gebruikt, refereer ik met het begrip 'protocol' aan een gestandaardiseerde (en dus in brede gremia besloten en algemeen geldige) handelingswijze. De in de tekst genoemde 'handelingsrichtlijn' valt hier dus niet onder.

20 In dergelijke situaties hebben de artsen geen andere keus dan het kind te laten overlijden.

21 Jargon voor het wegzuigen van bloed en ander vocht uit het operatiegebied.

22 Middleton \& Curnock (1995).

23 Zie voor een discussie over de relatie tussen technologie en verpleegkundige praktijk Barnard (1997) en Walters (1995). Het kind wordt niet alleen geobserveerd door verpleegkundigen en apparaten. Ook de arts houdt de toestand van het kind nauwlettend in de gaten. Zie voor een uitgebreide beschrijving van het dagelijks lichamelijk onderzoek van de arts hoofdstuk 2 Pasgeboren en onbepaald.

24 De postfenomenoloog Ihde (1990) onderscheidt twee manieren waarop artefacten een bemiddelende rol spelen in de relatie tussen mens en wereld. De eerste betreft een inlijvingsrelatie. Hierbij wordt de techniek ingelijfd in de lichamelijkheid van 
mensen. Een duidelijk voorbeeld van deze vorm van bemiddeling is een bril. We kijken niet naar de bril, maar door de bril naar de wereld om ons heen en vergeten dat we hem op hebben. De bril zelf verdwijnt naar achteren, buiten ons gezichtsveld en wordt transparant. De tweede bemiddelingsrelatie noemt Thde een hermeneutische relatie. Hierbij biedt het artefact een representatie van de wereld. Een voorbeeld hiervan is een monitor. De monitor is niet transparant. De staf kijkt naar de monitor. Wil de staf weten hoe het met het kind gaat dan moet zij het apparaat aflezen én interpreteren. Voor de vertaalslag van Ihde's begrippen naar het Nederlands heb ik gebruikgemaakt van Verbeek (2000).

25 Zie over de verschuiving naar digitale data in de geneeskunde onder andere Reiser (1978) en Strauss et al. (1985).

26 Volgens Reiser en Anbar (1984) zijn het niet zozeer de dramatische gebeurtenissen die zich op een intensive care voordoen, maar de dagelijkse technische routines die tot stress leiden bij de stafleden. Het burn-out verschijnsel is een belangrijk object van onderzoek binnen de gezondheidswetenschappen. Het valt echter buiten het kader van mijn studie.

27 Widdershoven \& Verkerk (r995).

28 Vergelijk Cooper (1993) Smits (1995) Mesman (1995) en Walters (1995).

29 Zie voor een uitgebreide deconstructie van de dichotomie techniek - zorg Berg \& van der Lyke (1995).

30 Niet alleen high technologies zoals een beademingsapparaat, maar ook low technologies, zoals het patiēntendossier, geven actief vorm en inhoud aan het handelingstraject. Zie hoofdstuk 2 Pasgeborenen onbepaald.

31 Verbeek (2000) p.179.

32 Deze betekenis ontleen ik aan de actor-netwerk theorie. Of zoals Madeleine Akrich het formuleert: 'Thus, like a film script, technical objects define a framework of action together with the actors and the space in which they are supposed to act.' (Akrich 1992, p.208). Bij het ontwerp van een artefact, zoals een beademingsapparaat, heeft men een specifiek gebruik voor ogen. Dit script is in de opzet van het instrument ingeschreven (in-scriptie) en schrijft een bepaalt gebruik voor (prescriptie). Zie Akrich \& Latour (1992) en Latour (1993). Hoewel ik de materiële omgeving (bijv. apparaten, de architectuur van het ziekenhuis) als actief structurerend element van een praktijk beschouw, blijf ik in tegenstelling tot de actor-netwerk theoretici in mijn analyse een onderscheid maken tussen mensen en dingen. Dit biedt de (conceptuele) mogelijkheid om de eigen ervaring, keuzes en verantwoordelijkheid van mensen te erkennen en te onderzoeken. Vergelijk Oudshoorn (1996) en Verbeek (2000).

33 Dit impliceert echter niet dat de staf deze specifieke vorm van gebruik ook altijd onderschrijft. Zij kunnen besluiten een apparaat terzijde schuiven, gedeeltelijk in te zetten, of op een geheel eigen wijze te gebruiken.

34 Zic hoofdstuk 2 Pasgeboren en onbepaald.

35 Het script dat bijvoorbeeld in een protocol is ingeschreven, disciplineert de praktijk zodat het ondanks haar heterogene, dynamisch karakter een stabiel, uniform en voorspelbaar geheel wordt. Alleen in zo'n praktijk kan een protocol werken. Een protocol schept niet alleen een praktische orde, maar het gebruik ervan veronderstelt eveneens een reeds bestaande orde. Zie voor de de-scriptie van de status en het protocol, Berg (1997b). 
36 Zie voor andere voorbeelden van de normativiteit in medische technick (Berg \& van der Lyke 1997) en Oudshoorn (1995).

37 Zie ook Harbers \& Koenis (1997) p.117.

38 Er zijn verschillende manieren waarop de relatie tussen de sociale orde en de matericle orde wordt ingevuld. Binnen bijvoorbeeld het interacticf materialisme geldt als uitgangspunt dat zowel de sociale orde als de matericle orde uit zowel mensen als dingen opgebouwd zijn en dat beiden daarin een actieve rol in spelen. Hiermee verdwijnt de oppositionele relatie tussen de wereld der mensen en de wereld der dingen. Zie voor de discussie hierover in de Nederland Harbers (2001) Harbers \& Koenis (1999) Mol \& Harbers (1994) en De Vries (2001). Zie op dit punt ook Law \& Mol (r995).

39 Harbers \& Koenis (1997).

40 Hiermee zou de kritick op het instrumentalisme doorschieten naar een technologisch determinisme, waarin technologie de allesbepalende factor is. Een technologisch-deterministisch standpunt gaat op zijn beurt geheel voorbij aan het aanded van de gebruikers in de structurering van het traject en de specifieke wijze waarop in het gebruik ook techniek zelf verandert. Om te onderzoeken in welke mate en op welke wijze techniek en andere dingen het handelingsproces mede vormgeven, is het noodzakelijk om het ingeschreven script (in-scriptic) te expliciteren (de-scriptie). Deze explicitering is een noodzakelijke stap om het script ter discussie te kunnen stellen en eventueel te veranderen (Akrich 1992).

$4 \mathrm{Zie}$ voor andere voorbeelden van deze dialectische relatie tussen mens en techniek de verschillende bijdragen in de bundel 'De macht der dingen'. De auteurs laten op grond van verschillende casestudies zien dat technologie niet alleen moet worden opgevat als een product van onze cultuur, maar evenzogoed als producent van onze cultuur. In het gebruik wordt zowel de technologie zelf als de cultuur - bijv. de afdeling - waarin het gebruikt wordt, gedefinieerd. Zie Van der Geest et al. (1994).

42 De rol van techniek blijkt in deze situatie niet voor alle betrokkenen hetzelfde. Voor sommige is techniek een verlengstuk van de handelende arts en wordt de verantwoordelijkheid voor Toms situatie op het conto van het 'Menselijk ingrijpen' geschreven. Voor anderen is techniek geen middel, maar een dader en wordt als zodanig onder de noemer 'Natuur' geschaard. Zie voor een gedetailleerde analyse van wat door wie op het conto van de 'Natuur' wordt geschreven, en wat op dat van het 'Menselijk handelen' Mesman (1992).

43 De schadelijke werking van een apparaat doet niets af aan de stelling dat aandacht voor techniek ook zorg voor het kind is en omgekeerd.

44 Guillemin \& Holmstrom (1986) p.131.

45 Vergelijk Lynch (1985).

46 Deze vraag heb ik eerder, zij het minder uitvoerig, uitgewerkt in het artikel 'De diagnose gedigitaliseerd: Observaties op een neonatologieafdeling.' (1993).

47 De laatstgenoemde benadering van getallen valt onder de 'enumerologie'. In de enumerologie gaat het niet zozeer om de waarde van de getallen, maar om de sociale processen waarin ze tot stand komen en de wijze waarop ze vorm geven aan onze realiteit (Bogdan and Ksander 1980).

48 Gigerenzer (1990).

49 Zie ook hoofdstuk 3 Reisgenoten.

so De hiërarchie binnen een ziekenhuis laat meer of minder ruimte voor onzekerheid. Een arts-in-opleiding die te vaak te zeker is, wordt niet als positief beoordeeld. 
Daarnaast weten stafartsen ook niet altijd wat er aan de hand is, al verwacht men dat wel van hen.

sI Vergelijk Lave (1988).

\$2 De vraag dringt zich op wat er nog overblijft van de medische praktijk als we de getallen weghalen. Kan die praktijk bestaan zonder de aanwezigheid van getallen? Een geneeskunde zonder getallen is mogelijk, maar is een andere medische praktijk, anders qua denkstijl, identiteit en medische handelingen. Voor het bestaan van een dergelijke ongekwantificeerde medische praktijk moeten we terug naar het begin van de negentiende eeuw. Daar kunnen we de laatste activiteiten en denkbeelden vinden van een kwalitatieve reguliere geneeskunde. Warner (1986) beschrijft de opkomst van het kwantitatieve denken in de geneeskundige praktijk. Voor de medici uit de negentiende eeuw is ziekte een verstoring van het natuurlijk evenwicht. Het was aan hen om de homeostase te herstellen. Essentieel hierbij was de subjectieve ervaring van de patiënt en de informatie over de specifieke situatie waarin deze verkeerde. Elke patiěnt was een geval apart en onderlinge vergelijking werd dan ook als zinloos beschouwd. Om de rust te doen wederkeren behoorden aderlaten en overvloedige toediening van alcoholhoudende dranken tot het standaardpakket van de medische behandeling. In de loop van de negentiende eeuw worden steeds meer getallen door medici binnengehaald. Hiermee moet de oude manier van medisch denken en doen plaatsmaken voor een nieuwe geneeskundige praktijk. In deze gekwantificeerde geneeskunde wordt gezondheid als 'natuurlijk' ingeruild voor 'normaal'. Men ziet geen verstoorde balans van de algehele conditie meer, maar een afwijking van een afzonderlijk fysiologisch systeem of orgaan. Het is niet meer de overmatige stimulatie van het natuurlijke evenwicht waarop men de blik richt, maar de groeiende hoeveelheid ziekte-entiteiten. Hierbij staat niet meer de subjectieve ervaring van de patiënt centraal, maar objectieve meetresultaten. De medische wereld 'verwetenschappelijkt'. Hierin staat zij niet alleen. Ook andere takken van wetenschap, evenals het dagelijks leven, raken in de ban van getallen. Zie voor een historische beschrijving van deze verandering Gigerenzer (1990) Hacking (1990) en Porter (1995).

1 In de praktijk blijken verpleegkundigen eerder de continuering van een behandeling ter discussie te stellen dan artsen. Vergelijk op dit punt Zussman (1992), p.69 n.7. Dit wil echter niet zeggen dat altijd dezelfde posities worden ingenomen. Het kan ook voorkomen dat de medische staf voor een niet-reanimatic beleid is en verpleegkundigen zich tegen het staken van de behandeling keren (Eliasson et al. 1997).

2 Ik kies hier voor het begrip 'positie' en niet voor het begrip 'perspectief omdat het perspectivisme uitgaat van éen werkelijkheid. Hierin biedt elk perspectief slechts zicht op een deel van de werkelijkheid. Door diverse invalshoeken te combineren zou er, aldus de perspectivist, een meer volledig beeld van de werkelijkheid ontstaan (De Wilde 1992, p.31 e.v.). Zie ook De Wilde (1987).

3 Dit gelde niet alleen voor de visie op een prognose. Ook over andere onderwerpen hebben artsen en verpleegkundigen uiteenlopende visies. Dit kan aanleiding geven tot conflicten. Zie voor een historisch overzicht van onderzock naar de arts-verplecgkundige relatie en haar conflicten McMahan, Hoffman \& McGee (1989). 
4 Zie ook hoofdstuk 4 Een onzeker traject.

5 Deze methodologische keuze en de uitwerking daarvan zijn gebaseerd op de studie van Anspach (1993), die in haar onderzoek laat zien hoe de taakverdeling op een NICU doorwerkt op de perceptie van de prognose van een kind.

6 Op deze wijze fungeert de organisatiestructuur van de afdeling als cen 'wology of knouledge' (Anspach 1993, p.60). Anspach hanteert een ecologische benadering. In deze benadering wordt de productie van kennis expliciet gesirueerd in de specifieke omstandigheid warin zij wordt geproduceerd. In het gebruik van deze metafoor wordt 'ecologie' niet opgevat als cen gesloten eco-systeem, maat als een set afhankelijkheidsrelaties (Star 1995, p.35 n.to).

7 Door de aandacht te vestigen op de koppeling tussen de professionele positie en prognostische kennis dreigt echter de ouder als producent van dergelijke kennis buiten beeld te raken. Ook ouders ontwikkelen hun eigen vorm van prognosticering. Het is daarom belangrijk de praktische context te onderzoeken warin ouders hun weg proberen te vinden in de complexe omstandigheden die zich op een NICU voordoen en op welke wijze zij tot een antwoord komen op de vraag naar de toekomstverwachting van hun kind. Anders dan Anspach (1993) zal ik mijn analyse niet beperken tot stafleden. Ouders zoeken hun eigen referenticpunten om houvast te vinden. Vergelijk ook de kritiek van Layne (1996).

8 Koselleck (1985) wijst erop dat dit ervaring en verwachting nog niet tot complementaire begrippen maakt. Ze zijn van een geheel andere orde. Verwachtingen kunnen bijvoorbeeld nog veranderen. Ervaringen niet meer. Die zijn reeds geweest en liggen opgeborgen in 'de ervaringsruimte' (p,27o). Verwachtingen zijn gedistribueerd over oneindige temporele vertakkingen die zich achter de horizon uitstrekken. Achter deze verwachtingshorizon opent zich een nieuwe ervaringsruimte, die echter nog niet zichtbaar is (p.273). Hier ligt tevens een probleem: ook het onverwachte kan zich voordoen en daar moet rekening meegehouden worden. In het prognosticeringsproces worden verwachtingen onthult die niet gededuceerd worden uit de ervaring. De ervaringsruimte schiet tekort om de verwachtingshorizon te bepalen (p.275). Waar ervaring wel het spectrum aan verwachtingen incorporeert, is ervaringsruimte te beperkt om het hele scala aan toekomstmogelijkheden te overzien.

9 De concrete handelingspraktijk als niveau van onderzoek neem ik in mijn analyse wel mee. Zo blijft het inzicht dat specifieke bezigheden van belang zijn bij de totstandkoming van prognostische kennis behouden, maar spelen sociale groepen geen restrictieve rol meer in de analyse ervan. Ik verlaat hier het kader van de professiesociologic.

to Emotionele betrokkenheid wordt hier niet veroordeeld zoals dat in het cognitivistisch raamwerk gebeurt. Daar zou het per definitic het zicht op de situatic ontnemen. Hier wordt het echter als een belangrijke component van het beoordelingsproces beschouwd. Vergelijk Benner, Tanner \& Chesla (1996). Zie ook Palmer \& Noble (1985).

II Het is opvallend hoe ook hier de situatic van deze verpleegkundigen in een psychologisch vocabulaire wordt geduid.

12 Schlomann (1994).

13 Vergelijk Anspach (1993).

14 Vergelijk Benner, Tanner \& Chesla (1996) en Schraeder \& Fischer (1987).

Is Voor een bespreking van de grens tussen menselijk en monsterlijk, zie Schlomann (1994). 
De gevolgen van een langdurig hands-off beleid voor de emotionele ontwikkeling van een kind zijn onduidelijk, maar de heersende opvatting is wel dat het een kind op dit vlak geen goed doet (Sparshott 1997).

17 Zahr \& Balian (1995).

18 Voor een uitgebreid overzicht, zie Sparshott (1997).

19 Nog niet zo lang geleden was de heersende opvatting dat pasgeboren kinderen en prematuren in het bijzonder, geen pijnervaring zouden kennen. Deze opvatting is reeds jaren verlaten en pijn bij neonaten geldt nu als een belangrijk terrein van onderzoek. Zie bijv. Bours et al. (1997).

20 Ook omgevingsfactoren, zoals licht, geluid, kou en hitte, kunnen hinderlijk zijn voor een kind. Vooral schel licht en lawaai zijn een bron van stress. Het vele licht, lawaai en de dagelijkse reeks aan interventies leiden tot een verhoogde hart- en ademhalingsfrequentie en een daling van de saturaties. Vergelijk Allen (1995) en Zahr \& Balian (1995).

21 Frader (1979).

22 Dit begrip ontieen ik aan Koselleck (1985).

23 Binnen cognitivistische modellen van de medische praktijk speelt theoretische kennis de hoofdrol. Hierin is prognosticeren enkel een kwestie van deductie. Zie voor cen kritiek op deze cognitivistische benadering met betrekking tot de geneeskunde Berg (1997b) en met betrekking tot de verpleegkunde Benner (1984), en Benner, Tanner \& Chesla (1996).

24 Statistische kansen spelen een belangrijke rol in het prognosticeringsproces. Maar de ene kans is de andere niet. Sommige komen voort uit jarenlang onderzoek en ervaring, andere zijn gebaseerd op studies met kleine populaties. Voor extreem premature kinderen zijn resultaten van grootschalige studies nog niet voorhanden. Kleine casestudies moeten dan in een cerste behoefte voorzien. Dergelijke onderzocksresultaten behoren niet tot de hardcore van de professionele kennis. In de praktijk betekent dit dat de ene neonatoloog de prognose op basis van een andere studie bepaalt dan de andere neonatoloog. Het prognostisch verschil tussen de neonatologen over de kansen van Maureen is hiervan een extreem voorbecld. Waar de éen Maureen vijftig procent kans geeft, ziet de ander een geheel ander kind. Een geval als dat van Maureen wordt het individuele karakter van de ervaringsruimte van artsen uitvergroot.

25 Uitspraak van een verpleegkundige in het Academisch Centrum.

26 Binnen de medische praktijk vormt de verwijzing naar onverwachte uitkomsten in de vorm van anekdotes zelfs een gebruikelijk deel van de kennisoverdracht. Vergelijk Benner. Tanner, and Chesla (1996) en Hunter (1991).

27 Van Vree (1998) duide het complex van verschijningsvormen van historisch besef aan als historische cultuur. Hij maakt hierbii gebruik van het werk van Koselleck. Van Vree wijst op het feit dat de implicaties van het werk van Koselleck voorbij de grenzen van de historiografie reikt. De verschillende vormen van historisch besef, alsmede de verschuivingen daarin, hebben implicaties voor de wijze waarop de werkelijkheid wordt gepercipieerd.

28 Koselleck (1985).

29 Vergelijk Koselleck (1985) 'rational prognosis'.

3o Kenmerkend voor dit historisch besef is de acceleratic van tijd en de onbekendheid over wat komen gaat (Koselleck 1985).

31 Vergelijk Guillemin \& Holmstrom (1986) en Layne (1996). 
32 Naast de mondelinge informaticoverdracht zijn er ook verschillende voorlichtingsboeken voor ouders geschreven. Zie bijvoorbeeld De Leeuw \& Bakker ( 1995).

33 Vergelijk De Leeuw \& Bakker (t995).

34 Layne (1996), p.635.

35 Vergelijk Anspach (1993), Frohock (1986) en Schlomann (1994).

36 Vergelijk Anspach (1993).

37 Layne (1996), p.633.

38 Layne (1996) wijst op het cyclische karakter van een rit op de achtbaan: je komt steeds weer terug bij waar je bent begonnen en er is dus geen enkele voortgang. De rollercoastermetafoor sluit an bij een cyclisch historisch besef, terwiil de graduationmetafoor beter past bij de lineaire vorm.

39 Ook bij de interpretatie van temporele bakens zoals ritme en tempo, maken de betrokkenen gebruik van verschillende repertoires. In het cyclisch repertoire is het tijdschema het vaste ijkpunt waaraan de ontwikkeling van een kind wordt afgelezen. Hierbij dient te worden opgemerkt dat de staf de uniciteit van de kinderen in de beoordeling meeneemt. In cen lineaire repertoire staat niet zozeer de situatie van het kind ter discussie, maar het tijdschema zelf: in hoeverre loopt het in de pas met de ervaring die men in de dagelijkse praktijk opdoet.

40 Een klassick voorbeeld van een studie naar de temporele ordes van een ziekenhuis is het onderzoek van Zerubavel (1979) waarin de temporele orde aan de hand van onder meer stafrotatic en werkschema's wordt bestudeerd.

41 Vergelijk de notic van temporele matrix zoals uitgewerkt door Strauss et al. (1985).

42 Mensen brengen ook hun eigen temporaliteit mee de afdeling op. Het temporele schema van ouders loopt niet altijd synchroon met dat van de afdeling. Als gevolg van de vele medische series op televisie waarin alles binnen een zeer kort tijdsbestek wordt afgehandeld, kunnen irreèle verwachtingen ontstaan over diagnose en behandelingsduur. Vergelijk ook de kritiek van Strauss et al. (1985) op het onderzoek van Zerubavel.

43 Davies (1994).

44 Procesgerichte tijd laat zich niet makkelijk op voorhand bepalen. Maar ook niet altijd achteraf. Activiteiten kunnen gelijktijdig worden uitgevoerd of onderbroken worden. Tijd is hier een deelvan vele verschillende voortgaande concrete processen. Dit maakt het moeilijk om aan te geven wanneer iets is begonnen of geéindigd. Procesgerichte tijd laat zich niet inroosteren of meten. Daarvoor zijn de grenzen te vlociend (Davies 1994).

45 Het feit dat Maureen de eerste achtenveertig uur had overleefd werd door sommige verpleegkundigen juist als een nadeel gezien. Het kind had nu juist minder kans om zelf te sterven.

46 Zie met betrekking tor dit punt ook Latour (1988; 1993).

\section{DE MORELE LADING}

1 Delen van deze analyse heb ik reeds uitgewerkt in het artikel: 'Dwingende feiten en hun verborgen moraal: over doen en laten in de neonatologiepraktijk' (1996).

2 Zie ook het eerste hoofdstuk Neonatologie: een praktijk in beweging.

3 Bijvoorbeeld het KNMG-rapport (1990). 
4 Ook het rapport van de KNMG-commissie maakt dit onderscheid. Zij spreekt over 'een niet-reële overlevingskans'-prognose en 'een onleefbaar leven'-prognose. Nederlandse Vereniging voor Kindergeneeskunde (1992), p.43.

6 Nederlandse Vereniging voor Kindergeneeskunde (1992), p.44.

7 Nederlandse Vereniging voor Kindergeneeskunde (1992), p.45.

8 Bij de opstelling van regels en procedures heeft men niet alleen een specifiek beeld voor ogen van de wijze waarop (morele) kwesties moeten worden aangepakt, maar ook van het probleem en de praktijk waarin deze zich voordoen. De door de richtlijnen veronderstelde structuur wordt niet alleen als een 'gewenste orde' beschouwd, maar ook als een 'realiseerbare orde'. Met andere woorden, de richtlijnen leggen een realiseerbaarheidsclaim op tafel: dat wat gewenst is, is ook mogelijk. Met deze aanspraak veronderstellen zij de aanwezigheid van een specifieke praktijk. Een praktijk waarin deze regels werken. Dit impliceert dat de richtlijnen niet alleen morele oordelen in zich dragen, maar ook vooronderstellingen over de werkelijkheid (Swierstra 1994).

9 Met deze opzet sluit dit script aan bij de rationaliteit van evidence-based geneeskunde.

Io Nederlandse Vereniging voor Kindergeneeskunde (1992), p.32.

II Vergelijk Nauta (1972), p.23.

12 Hieruit mag niet de conclusie worden getrokken dat men naast de couveuse altijd een situationeel repertoire hanteert. Repertoires zijn niet gebonden aan een bepaalde locatie. Tijdens bijvoorbeeld een grote visite, dat op de NICU zelf plaatsvindt, wordt veelvuldig naar onderzoek in de literatuur verwezen en hanteert men een gevalsrepertoire.

13 In de discussic over de ouders domineerden het psychosociale en het juridische vocabulaire. Zie hoofdstuk 3 Reisgenoten waarin een ander deel van de stafvergadering wordt geanalyseerd.

14 Dit maakt bet tevens onmogelijk om moraliteit ter discussie te stellen zonder dat de feitelijkheid hierbij betrokken raakt. Men kan niet met elkaar een moreel conflict aangaan en het intussen wel eens zijn over de feiten. Morele dissensus sluit bijgevolg feitelijke consensus uit. In het Handboek Gezondheidsethiek doet Kuitert, hoogleraar ethick, een voorstel voor een moreel beraad. In dit voorstel wordt er wel vanuit gegaan dat een meningsverschil over moraliteit kan worden afgezonderd van de feitelijke situatic. Dat het zuiver kan zijn, louter de vraag naar het goede kan betreffen. De procedure zegt niet dat de feitelijke situatie buiten beschouwing blijft. De feiten worden echter alleen opgevoerd als 'informatief element'. De situatie waar het kind zich in bevindt en de handelingsopties waaruit de betrokkenen een keuze moeten maken, zijn gegeven. In de bespreking die volgt zou de nadruk behoren liggen op de verschillende morele overwegingen die bij de keuze voor één van de handelingsopties een rol spelen (Kuitert 1988).

is Zie over het proces van universaliseren en lokaliseren Gabricls (2000) en Timmermans \& Berg (1997).

16 Nussbaum (1986) lokaliseert ethiek in de wijze waarop men met de gevolgen van de beslissing omgaat.

17 Het begrip 'morele kosten' ontleen ik aan Williams (1981). Morele kosten zijn de uitkomst van een moreel dilemma. Bij een keuze tussen twee kwaden blijft er altijd de pijn, de morele last, van de beslissing. Dit zijn de morele kosten die er aan elke keuze in een moreel dilemma verbonden zijn. 
Verschillende verpleegkundigen uit zowel het Academisch Centrum als het Northeastern General Hospital zetten echter vraagtekens bij de praktijk van het beslissingsrecht van ouders. In hun ogen komen ouders pas aan het woord als artsen het spoor bijster zijn of verdere behandeling niet meer zinvol lijkt. Dit zou pas gebeuren als de medische mogelijkheden zouden zijn uitgeput. 'Het lijkt wel of ouders pas mee mogen praten als artsen het zelf niet meer weten', aldus een verpleegkundige uit het Academisch Centrum.

19 Zie voor een uitgebreide beschrijving van de distributie van verantwoordelijkheid russen staf en ouders, hoofdstuk 3 Reisgenoten.

20 Zie hierover hoofdstuk 5 Bakens aan de horizon.

2. Vergelijk ook Holm et al. (1996).

22 Zie voor een uitgebreide bespreking hoofdstuk 3 Reisenoten.

23 De machtsverhouding tussen de arts en verpleegkundige is een belangrijk object van studie binnen verschillende disciplines zoals medische sociologie en verplegings: wetenschappen. In de bespreking van de relatic tussen arts en verpleegkundigen is een verschuiving waat te nemen. In de eerste instantie worde de relatie tussen artsen en verpleegkundigen beschreven vanuit een dominantiemodel waarin de arts beslist en de verpleegkundige gehoorzamt (Freidson 1970). Dit beeld wordt echter al snel bijgesteld. Verpleegkundigen zouden wel degelijk invloed uitoefenen op de behandeling. Alleen niet openlijk. De relatie tussen arts en verpleegkundigen wordt daarom gekarakteriseerd als een spel - 'doctor-nurse game' - waarin het handhaven van de sociale orde voorop staat (Stein 1967). Dit betekent dat openlijke onenigheid uit den boze is. Dit wordt vermeden doordat verpleegkundigen hun advies aan artsen zodanig 'verpakken' zodat deze het zonder gerichtsverlies alsnog als een eigen idee naar voren kunnen brengen. Op deze wijze vormt de kennis van verplecgkundigen geen bedreiging voor de hiërarchische orde. Als gevolg van diverse sociale veranderingen zoals de toename van vrouwelijke artsen, de sociale status van artsen en de professionalisering van verpleegkundigen houdt het dominantiemodel noch de 'doctor-nurse game' stand. De weergave van de praktijk in termen van machtsblokken wordt vervangen door een beschrijving in termen van een 'negotiated order'. Zie hierover Hughes (1988), Porter (1991), Stein (1969), Stein, Watts \& Howell (1990) en Strauss et al. (1963). In deze onderhandelingspraktijk hebben verpleeg. kundigen steeds meer ruimte gekregen. Dit als gevolg van een erkenning van het belang van de sociale dimensie in de behandeling van patiènten en de invoering van teamverpleging en gezamenlijke patiëntenbesprekingen (Svensson 1996). Zie voor een historisch overzicht van deze ontwikkeling McMahan, Hoffman \& McGee (1989) en Pillitteri \& Ackerman (1993).

24 Doordat ik niet in de gelegenheid was om bij deze vergadering aanwezig te zijn, kan ik geen verslag doen van de wijze waarop men tot dit besluit is gekomen.

25 Zie voor de symbolische betekenis van reanimatie Nolan (1987).

26 Zie voor een analyse van de controverse over de definitie van en de criteria voor de dood Lock (1996) en Wackers (r994).

27 Vergelijk het begrip 'Cyborg' van Haraway (1991) dat verwijst naar een kruising tussen mensen en machines; cybernetische organismen.

28 Een klassieke studie naar de sociale organisatie van sterven in een ziekenhuis is het onderzock van Sudnow (1967).

29 Schlomann and Fister (1995). 
30 Dit is geen verplichting. Sommige ouders willen dit niet en het kind blifft dan gewoon in de couveuse liggen.

31 Opluchting is slecht een van de gevoelens die zich na het overlijden van een kind op de NICU voordoet. In hun studie naar rouwverwerking van verpleegkundigen op een pediatrische IC beschrijven Rashotte, Fothergill-Bourbonnais \& Chamberlain (1997) dat opluchting zich voornamelijk bij ervaren verpleegkundigen voordoet. Het overlijden van een kind leidt ook tot schuldgevoel, boosheid en intens verdriet. Verpleegkundigen hebben verschillende manieren om gevoelens van rouw op te vangen. Bijvoorbeeld door er veel met elkaar over te praten of hun gevoel onder controle houden door zich emotioneel af te schermen wanneer duidelijk is dat het kind gaat overlijden. In de rouwverwerking van verpleegkundigen speelt de relatie met de familie van het kind een belangrijke rol. Een goede verstandhouding met deze ouders en de mogelijkheid om hen te steunen, helpt verpleegkundigen om met hun eigen gevoelens van verdriet om te gaan. Een slechte relatie met de ouders werkt, aldus Rashotte et al. op een negatieve manier door op de rouwverwerking van verpleegkundigen. Zie ook Downey et al. (1995).

\section{HET EINDE VAN DE REIS}

1 Daarom kan bijvoorbeeld een ethisch handboek het voorstel doen dat eerst de feiten duidelijk moeten zijn en dan pas de morele overwegingen op tafel kunnen komen. Zie bijvoorbeeld het voorstel van een moreel beraad van Kuitert (1988). Vergelijk 'the fragility of goodness' van Nussbaum (1986).

3 Williams (1981).

4 Vergelijk het begrip 'endogene normativiteit' zoals gebruikt door Ter Meulen \& Berg (1999). Dit begrip moet niet verward worden met het begrip 'interne moraliteit' dat verwijst naar de specifieke morele orde van de afdeling. Endogene normativiteit beperkt zich niet tot morele normen.

5 Het begrip 'exnovatie' ontleen ik aan De Wilde (2000).

6 Het Leids Universitaire Medisch Centrum (LUMC) heeft dit besluit onder andere genomen op basis van de uitkomsten van een Brits longitudinaal onderzoek waarin premature kinderen (geboren voor de 26ste week) dertig maanden werden gevolgd (Wood et al. 2000). Twee derde van de kinderen overleed kort na de geboorte. Van hen die bleven leven zijn de meeste ernstig gehandicapt (van der Broek 2001). Op het moment dat het LUMC haar besluit kenbaar maakten, verschenen ook de resultaten van een longitudinaal onderzoek in eigen land, het POPS-onderzoek. Dit onderzoek volgt sinds 1983 kinderen die voor hun $32 s t e$ week werden geboren en nu in hun puberteit zitten. Deze kinderen blijken later ernstige leer en gedragsproblemen te hebben die met het klimmen der jaren toenemen (Verloove-Vanhorick, Ouden den, \& Walther 2001). Ook de resultaten van het POPS-onderzoek speelden een rol in de besluitvorming van de Leidse neonatologen om kinderen die al na de 24 ste week worden geboren niet meer te behandelen. Een ander voorbeeld waarbij de benedengrens van behandelen 'opnieuw' werd opgehoogd is Justin, een kind dat zo'n tien jaar geleden na vijfentwintig weken ter wereld kwam en na een restrictief beleid alsnog werd behandeld. Was hij echter vandaag geboren, met dezelfde problematiek en onder de hoede van dezelfde kinderarts, dan had deze zijn behandeling gestaakt. Dit voorbeeld is ontleend aan een interview met kinderarts Richard de Leeuw (Koclewijn 1999). 


\section{Literatuur}

Akrich, M.

1992 'The de-scription of technical objects.' In: Shaping Trehnology. Building Seciery. Studies in Sociotechnical Change, edited by W, E. Bijker and J. Law. Cambridge, MA: MIT Press.

Akrich, M. \& B. Latour

1992 'A summary of a convenient vocabulary for the semiotics of human and nonhuman assemblies.' In: Shaping Technology/ Building Society, edited by W. E. Bijker \& J. Law, Cambridge: The MrT Press.

Allen, A.M.

1995 'Stressors to neonates in the neonatal unit.' Miduives 108 (1288):139-141.

Amann, K. \& K. Knorr-Cetina

1989 Thinking trough talk. An ethnographic study of a molecular biology laboratory. Knowledge and society 8:3-26.

Anspach, R.

1987 'Prognostic conflict in life-and-death decisions: The organization as an ecology of knowledge.' Journal of Health and Social Behavior 28 (September):215-231.

1993 Deciding who lives: faithful choices in the intensive-care nursery. Berkeley: University of California Press.

Arnold, R.M. \& L. Forrow

1993 'Empirical research in medical ethics: an introduction.' Theoretical medicine Atkinson, P. 14 (3):195-196.

1984 'Training for certainty.' Social science and medicine 19 (9):949-956.

Aylward, G.P., S.I. Pfeiffer, A. Wright \& S.J. Verhulst

${ }_{1989}$ 'Outcome studies of low birth weight infants published in the last decade:

Bal, R. a metaanalysis.' The journal of pediatrics III (4):515-520.

1998 Grenzenwerk. Over het organiseren van normstelling voor de werkplek. Enschede: Twente University Press.

Balk-Smit Duyzenkunst, F.

1989 'Geneeskunde en taal: bijwerking of bedoeling.' Nederlans tijdschrift voor

Barnard, A. geneeskunde 133 (43):2272-2274.

1997 'A critical review of the belief that technology is a neutral object and nurses are its master.' Journal of advanced nursing 26 (1):126-131. 
Bartley, M.

1990 'Do we need a strong programme in medical sociology?' Sociology of health $\sigma$ illness 12 (4):371-390.

Beauchamp, T.L. \& J.F. Childress

1979 Principles of biomedical ethics. New York: Oxford University Press.

Beaufort, I.D. de \& H.M. Dupuis (eds)

1988 'Handboek Gezondheidsethiek.' Assen: van Gorcum.

Bell, P.L.

1997 'Adolescent mothers' perceptions of the neonatal intensive care unit environment.' The journal of perinatal of neonatal nursing $\mathrm{II}(\mathrm{t}): 77^{-84}$.

Benner, $P$.

1984 From novice to expert. Excellence and power in clinical nursing practice.

Menlo Park: Addison-Wesley.

Benner, P., C. Tanner \& C. Chesla

1996 Expertise in nursing practice. Caring, clinical judgement, and ethics. New York: Springer.

Berg, M.

1996 'Practices of reading and writing: the constitutive role of the patient record in medical work', Sociology of health of illness 18 (4):499-524.

19972 'Problems and promises of the protocol', Social siience and medicine 44 (8):1081-1088.

1997b Rationalizing medical work. Decision-support techniques and medical practices. Cambridge, MA: The MIT Press.

1998 'Order(s) and disorder(s): of protocols and medical practices.' In: Differences in Medicine: Unraveling Practices, Techniques, and Bodies, edited by M. Berg \& A. Mol. Durham: Duke University Press.

Berg, M. \& S. van der Lyke

1995 'Tafeltje Dekje en het Internet. Het onderscheid tussen zorg en technologie herbeschouwd', Gezondheid. Theorie in praktijk 3 (3):254-265.

1997 'De normativiteit van een infuuspomp. Over zorgpraktijken en technologic.' In: Denken over zong. Concepten en praktijken, edited by M. Verkerk. Utrecht: Elsevier/ De Tijdstroom.

Bijker, W.E. \& J. Law (eds)

1992 Shaping technology / Building society. Studies in sociotechnical change. Cambridge, MA: MIT Press.

Bogdan, R., M.A. Brown \& S. Bannerman Foster

1982 'Be honest but not cruel: staff/parent communication on a neonatal unit', Human Onganization 41 (1):6-15.

Bogdan, R. \& M. Ksander

1980 'Policy data as a social process: A qualitative approach to quantitative data',

Bosk, C.L. Human Organization 39 (4):302-309.

1979 Fongive and remember: Managing medical failure. Chicago: The University of Chicago Press.

1980 'Occupational rituals in patient management', The New Engeland journal of medicine $303(2): 71-76$. 
1992 All god's mistakes. Genetic counseling in a pediatric hospital. Chicago: The University of Chicago Press.

Bours, G.J.J.W., H. Huijer Abu-Saad. J.P.H. Hamers \& R.T.M. van Dongen 1997 Pijnbeoordeling bij neonaten. Tijdschrifi noor Kindergeneskunde 65 (1):1-8. Bowlby, J.

1971 Attachment. second ed. 3 vols. Vol. 1. Attachment and Loss. London:

Brody, B.A. Penguin Group.

1993 'Assessing empirical research in bioethics.' Theoretical medicine 14 (3):211-219.

Broek, M., van der

2001 'Begrip voor verleggen grens hulp aan vrocggeborenen.' De Volloknant, 29 mei. Brom, F.W.A.

1992 'Primum non nocere. Het nalaten van levensverlengende handelingen bij

Bury, M.R. pasgeborenen.' Filosofie en Praktijk.138-145.

1986 'Social construction and the development of medical sociology.' Sociology of Cannon, S. bealth of illness 8:137-169.

1989 'Social research in stressful settings. Difficulties for the sociologist studying the treatment of breastcancer.' Sociology of health ó illness at (1):62-77.

Carson, D.P.

1996 'The socially complex family. New dilemmas for the neonatal social worker.' Clinios in perinatology 23 (3):609-620.

Casper, M. \& B. Koenig

1996 'Reconfiguring nature and culture: Intersections of medical anthropology and technoscience studies.' Medical anthropology quarterly $10(4): 523-536$.

Casper, M.J. \& M. Berg

I995 'Constructivist perspectives on medical work: Medical practices and science

Collins, H.M. and technology studies.' Science, technology, of human values 20 (4):395-407.

1985 Changing order. Replication and induction in scientific practice. London: SAGE Publications.

Cooper, M.C.

1993 'The intersection of technology and care in the ICU.' Advances in nursing science is (3):23-32.

Crigger, B.J.

1995 Bioethnography: Fieldwork in the land of medical ethics. Medical Antropology Quarterly 9 (3):400-417.

Davies, $\mathrm{K}$.

1994 'The tension between process time and clock time in care-work. The example of day nurseries.' Time of society 3 (3):277-303.

DeVries, R. \& J. Subedi (eds)

1998 Bioethics and Society. Constructing the ethical enterprise. New Jersey: Prentice Hall.

Downey, V., M. Bengiamin, L. Heuer \& N. Juhl

1995 'Dying babies and associated stress in NICU nurses.' Neonatal network 14 (I):4I-45. 


\section{Dubbelman, K.A. \& H.E.G.M. Hermans}

1990 Besluitvorming in de neonatologie. 's-Gravenhage: Vuga/ De Tijdstroom.

DuBose, E.R., R.P. Hamel \& LJ. O'Conell (eds)

1994 A matter of principles? Ferment in U.S. bioethics. New York: Trinity International Press.

Duff, R.S. \& A.G.M. Campbell

1973 'Moral and ethical dilemmas in the special care nursery.' The New England journal of medicine 289 (October 25):890-894.

Dupuis, H.M.

1988 'Patiënten in coma, een oplosbaar probleem.' Nederlands tijdschrift voor geneeskunde 132: 1926-1928.

1989 'Mag er nog gestorven worden? Het toenemende imperatief van de medische technologie.' In: Beslissen over leven en dood; dilemma's bij wilsonbekwame ernstig gehandicapte pasgeborenen, zwakzinnigen en psychogeriatrische patiënten, edited by L. Boon. Amstelveen: Stichting Sympoz.

Dupuis, H.M., P.J. Thung \& A.H.M. Kerkhoff

1992 Voordelen van de twiffel. Een inleiding tot de gezondheidsethiek. Houten: Bohn Stafleu Van Loghum.

Eliasson, A.H., R.S. Howard, K.G. Torrington, T.A. Dillard \& C.Y. Phillips

1997 'Do-not-resuscitate decisions in the medical ICU. Comparing physician and nurse opinions.' CHEST III (4):HO6-IIII.

Fox, R.

1957 'Training for uncertainty.' In: The student-physician. Introductory studies in the sociology of medical education., edited by R. K. Merton, G. G. Reader \& P. L. Kendall. Cambridge: Harvard University Press.

1988 Essays in Medical Sociology. Journeys into the field. 2nd, enlarged edition ed. Oxford: Transaction Books.

2000 'Medical Uncertainty Revisited.' In: Handbook of Social Studies in health and medicine, edited by Albrecht, G.L., R. Fizpatrick \& S. C. Scrimshaw. London: SAGE.

Frader, J.

1979 'Difficulties in providing intensive care.' Pediatrics 64 (1):10-16.

Franklin, $S$.

1996 'An excellent prognosis.' Medical anthropology quarterly to (4):683-686.

Freidson. E.

1970 Profession of Medicine. A study of applied knowledge. New York: Harper \& Row. Frohock, F.M.

1986 Special care: Medical decisions at the beginning of life. Chicago: The University of Chicago Press.

Gabrièls, R.

2000 'Simsalabimbambasaladusaladim.' Krisis. Tijdschrift voor empirsche filosofie 1 (1):89-107.

Garfinkel, H.

1967 Studies in Ethnomethodology. Englewood Cliffs, NJ: Prentice-Hall.

Geest, S. van der, P. ten Have, G. Nijhof \& P. Verbeek-Heida (red.)

1994 De macht der dingen: medische technologie in cultureel perspectief. Amsterdam: Het Spinhuis. 
Geertz, C.

1988 Works and Lives. The anthropologist as author. Stanford. California: Stanford University Press.

Gezondheidsraad 2000 Intensive care rond de geboorte. Den Haag: Gezondheidsraad.

Gigerenzer, G.

1990 The mpire of change: How probability changed science and eneroday liff. Cambridge: Cambridge University Press.

Gilbert, N. \& M. Mulkay

1984 Opening Pandora's Bex. A sociological analosis of scientiss 'discourse. Cambridge: Cambridge University Press.

Goffiman, E.

1974 Frame Analysis. An essay on the organization of experience. Cambridge: Harvard University Press.

Goodman, N.

1978 Ways of worldmaking. Indaniapolis: Hackett.

Goodman, N. \& C.Z. Elgin

1987 Reconceptions in Philosophy and other arts and sciences. London: Routledge.

Griffin, T., K. Kavanaugh, C.F. Soto \& M. White

1997 'Parental evaluation of a tour of the neonatal intensive care unit during a high-risk pregnancy.' Journal of obstetics, gynecology and neonatal numing 26 (1): $59-65$.

Grögaard, J.B., D.P. Lindstrom, R.A. Parker, B. Culley \& M.T. Stahlman

1990 'Increased survival rate in very low birth weight infants (1500 grams or less): no associaton with increased incidence of handicaps.' The journal of pediatrics 117 (1):139-146.

Guillemin, J.H. \& L. Lytle Holmstrom

1986 Mixed Blessings: Intensive Care for Newborns. Oxford: Oxford University Press.

Hacking, I.

1990 The taming of chance. Cambridge: Cambridge University Press.

1992 'The self-vindication of the laboratory sciences. In: Science as practice and culture, edited by A. Pickering. Chicago: University of Chicago Press.

Hak, T., P. ten Have \& A. Goethals

1992 'Kwalitatieve medische sociologie: nut en noodzaak.' In: Kwalitatieve medische sociologie, edited by T. Hak, P, ten Have \& A. Gocthals. Amsterdam: SISWO.

Hammersley, M. \& P. Arkinson

1983 Etnhography: Principles in practice. London and New York: Routledge. Haraway, D.

1991 A cyborg manifesto. New York: Routledge.

Harbers, $\mathrm{H}$.

$200 \mathrm{I}$ 'De geest is uit de fles.' Krisis 2 (1):79-86.

Harbers, H. \& S. Koenis

1997 'De wonderbaarlijke terugkeer van de niet-mensen.' In: Museum Aarde. Natuur: criterium of constructie?, edited by J. Keulartz \& M. Korthals. Amsterdam: Boom. 
1999 Ter Inleiding. Themanummer De bindkracht der dingen. Kennis en Methode 23 (1):3-10.

Have, H. ten

1990 Een hippocratische erfenis. Ethiek in de medische praktijk. Lochem: De Tijdstroom.

1992 Toekomsten van medische ethiek. Nijmegen: Katholieke Universiteit Nijmegen.

Have, H. ten \& G. Kimsma

1987 Geneeskunde tussen droom en drama. Voortplanting, ethiek en vooruitgang. Kampen: Kok, Agora.

Have, H. ten, G. Kimsma \& Sauer (eds)

1990 Ethiek en recht in de gezondheidszorg. Lochem: De Tijdstroom.

Have, H. ten \& A. Lelie

1998 'Medical ethics research between theory and practice.' Theoretical medicine and bioethics ig (3):263-276.

Heath, C.

1982 'Preserving the consultation: Medical record cards and professional conduct.' Sociology of health and illness 4 (1):56-74.

Heide van der, A.

1997 'Medical end-of-life decisions made for neonates and infants in the Netherlands.' The Lancet 350 (9073):251-255.

Heide, A. van der, P.J. van der Maas, G. van der Wal, L.A.A. Kollée, R. de Leeuw \& R.A. Holl

1998 'The role of parents in end-of-life decisions in neonatology: physicians' views and practices.' Pediatrics IOI (3):413-418.

Heimer, C.A. \& L.R. Staffen

1995 'Interdependence and reintegrative social control: labeling and reforming "inappropriate" parents in neonatal intensive care units.' American sociological review 60 (october):635-654.

Hendriks, R.

1992 'Scenes uit een pasgeboren leven. De constitute van een normatieve orde in het debat rond de neonatologiepraktijk.' Tijdschrift voor wetenschapsfilosofie en wetenschapsonderzoek 16 (4):294-312.

1993 'Gezondheidsrecht in wording. De semiotisch analyse van het traject van cen juridische uitspraak.' Gezondheid. Theorie in praktijk I (2):174-191.

Holm, S., P. Gjerve, G. Grode, O. Hartling, K. Ibsen \& H. Marcussen

1996 'Exhical reasoning in mixed nurse-physician groups.' Joumal of medical ethics $22(3): 168-173$.

Honig Bachman, D. \& R. Furlong Lind

1997 'Perinatal social work and the family of the newborn intensive care infant.' Social work in health care $24(3 / 4): 21-37$.

Hughes, D.

1988 'When nurses knows best: some aspects of nurse/doctor interaction in a casualty department.' Sociology of heath of illness to (r):1-22.

Hunter, K.M.

1991 Doctor's Stories, The narrative structure of medical knowledge. Princeton, NJ:

Princeton University Press. 
Ihde, D.

1990 Technology and the Lifruvorld. From gandens to earth.

Bloomington/Indianapolis: Indiana University Press.

Jonsen, A.R. \& S. Toulmin

1988 The Abuse of Cassistry. A bistony of monal reasening. Berkeley: University of California Press.

Karz, J.

1984 'Why doctors don't disclose uncertainty.' The Hasting Center Report (February):35-44.

Katz-Rothman, B.

1986 'Reflections: on hard work.' Qualitative sociology 9 (1):48-53.

Kaufert, P. \& J. Kaufert

1996 'Anthropology and Technoscience Studies: Prospects for synthesis and ambiguity.' Medical anthropology quarterly to (4):686-690.

King, D.

1987 'Social constructionism and medical knowledge: the case of transsexualism.' Saciology of health of illness 9 (4):351-377.

Klaus, M.J. \& J.H. Kennel

1970 'Mothers seperated from their newborn infant.' Pediatrics clinics of North America 17 (4):1015-10377.

Kleine, M.J.K. de, R. de Leeuw, L.A.A. Kollee \& H.M. Berger

1993 'Voortzetten of staken van levensverlengend handelen bij pasgeborenen.

Een onderzock in 4 centra voor neonatale intensieve zorg.' Nederlands tijdschrift voor geneeskunde 137 (10):496-500.

KNMG-Commissic Aanvaardbaarheid Levensbeetindgend

1990 Interim-rapport inzake levensbecindigend handelen bij wil-onbekwame patiënten. Deel I: zwaar-defecte pasgeborenen. Utrecht: KNMG

Knorr-Cetina, K.D.

1981 The Manufacture of Knowledge: An Essay on the Constructivist and Contextual Nature of Science. Oxford: Pergamon Press.

Koelewijn, J.

1999 'Doen of laten. Scheidend kinderarts Richard de Leeuw over dilemma's bij

Koops, B. vroeggeborenen.' NRC Handelsblad, 4 december 1999, 33.

1984 'Extreme Immaturity: a frontier in Neonatology.' American journal of diseases of children 138 (august):713-714.

Koppe, J.G.

1986 Bridging Birth: van neonatologie naar perinatologie. Utrecht: Bohn, Scheltema \&Holkema.

Koppe, J.G., e.a.

1989 Neonatologie. Utrecht: Bohn, Scheltema \& Holkema.

Koselleck, R.

1985 Futures Past. On the semantics of historical time. Studies in Contemporary German Social Thought. Cambridge, MA: The MIT Press.

Kuhn, T.S.

1962 The Structure of Scientific Revolutions. Chicago: University of Chicago Press. 
Kuitert, H.M.

1988 'Morele consensus: mogelijkheden en grenzen.' In: Handboek gezondheidsethick, edited by Beaufort, I.D. de \& H. M. Dupuis. Assen: Van Gorcum.

1989 Mag alles wat kan? Ethiek en medisch handelen. Baarn: Ten Have.

Latour, B.

1987 Science in action: How to follow scientists and engineers through society. Cambridge: Harvard University Press.

1988 The pasteurization of France. Cambridge: Harvard University Press.

1993 De Berlijnse sleutel en andere lessen van een liefhebber van wetenschap en techniek. Edited by R. Boomkens, E. Etry, L. Nauta, D. Pels \& G. de Vries, Kennis Openbare mening Politiek. Amsterdam: Van Gennep.

Latour, B. \& S. Woolgar

1979 Laboratory life. The construction of scientific facts. Princeton: Princeton University Press.

Lave, J.

1988 Cognition in practice, mind, mathematics and culture in everyday life. Cambridge: Cambridge University Press.

Law, J.

1994 Organizing modernity. Oxford \& Cambridge: Blackwell.

Law. J. \& A. Mol

1995 'Notes on materiality and sociality.' The Sociological Review 43 (2):274-294. Layne, L.L.

1996 "'How's the baby doing?" Struggling with narratives of progress in a neonatal intensive care unit.' Medical anthropology quarterly 10 (4):624-656.

1998 'Anthropological approaches in science and technology studies,' Science, technology of human values 23 ( 1 (special issue)).

Leenen, H.J.J.

1984 'Nalaten en beëindiging van behandeling bij ernstig gehandicapte pasgeborenen.' Nederlands tijdschrift voor geneeskunde 128:863-866.

1988 'Levensbeèindiging bij ernstig gehandicapte pasgeborenen. van neonatologie naar neothanatologie?' Medisch contact 43 (36): 1050-1052.

Leeuw, R. de, et al.

1996 'Foregoing intensive care treatment in newborn infants with extremely poor prognoses. A study in four neonatal intensive care units in the Netherlands.' The journal of pediatrics $129(5): 661-666$.

Leeuw, R. de \& L. Bakker

1995 Te vrocg geboren. Utrecht: Kosmos-Z\&K Uitgevers.

Leeuw, R. de, M. Cuttini \& M. Reid

1993 'Staff views on parental visiting of very low birthweight infants in neonatal intensive care units. Results of a staff enquiry actoss eleven countries of the European Community.' Journal of perinatal medicine 21 (1):43-52.

Light, D., Jr.

1979 'Uncertainty and Control in Professional Training.' Journal of health and social behavior 20 (December):310-322. 


\section{Lock, M.}

1996 'Death in a technological time: locating the end of a meaningful life.'

Medical anthropology quarterity to (4):575-600.

Lock, M. \& D. Gordon

1988 Biomedicine eurmined. Dordrecht: Kluwer Academic Publishers.

Lyke, S. van der

2000 Georganiseende liefile: Publike bemoeienis met zorg in de privbffer. Utrecht: Uitgeverij Jan van Arkel.

Lynch, $\mathrm{M}$.

1985 Art and Arrifuct in Laboratory Science: A Study of Shop Work and Shop Talk in a Reseanch Labonatory. Boston: Routledge \& Kegan Paul.

Lynch, M., E. Livingston \& H. Garfinkel

1983 'Temporal Order in Laboratory Work.' In: Sciencr Obsernen, edited by K. D. Knorr-Cetina \& M. Mulkay. Beveriy Hills: Sage.

Lyon, ].

1985 Playing God in the Nursery. New York: W.W. Norton \& Company.

Manschot, H. \& M. Verkerk (eds)

1994 Erthiek van de zorg: Een discussie. Amsterdam: Boom.

Mattingly, C.

1998 'In search of the good: narrative reasoning in clinical practice.' Medical anthropology quarterly 12 (3):273-297.

McMahan, E., K. Hoffman \& G. McGee

1989 'Physician-nurse relationships in clinical setrings: A review and critique of the literature, 1966-1992.' Medical Care Review 51 (1):83-112.

Meadow, W., T. Reimshisel \& J. Lantos

1996 'Birth weight-specific mortality for extremely low birth weight infants vanishes by four days of life: epidemiology and ethics in the neonatal intensive care unit.' Pediatrics 97 (5):636-643.

Mesman, J.

1992 'Machines en moraal. Verslag van een onderzoekservaring.' Krisis 48: 5-18.

1993 'De diagnose gedigitaliseerd: Observaties op een neonatologic-afdeling. Medische antropologie 5 (2): 239-254.

1995 'Techniek als figurant. Kanttekeningen bij de zorgethiek.' Gezondheid. Theorie in praktijk 3 (3):301-312.

1996 'Dwingende feiten en hun verborgen moraal: Over doen en laten in de neonatologiepraktijk.' Kennis en methode 20 (4): 377-397.

Meulen, R. ter \& M. Berg

1999 'Het normatieve karakter van richtlijnen onderzocht.' Tijdschrift voor sociale gezondheidzorg 77 (7):376-379.

Michael, $\mathrm{M}$.

1996 Constructing identities. The social, the nonhuman and change. London: Sage. Middleton, D. \& D. Curnock

1995 'Talk of Uncertainty: Doubt as an organisational resource for co-ordinating multi-disciplinary activity in neonatal intensive care.' Paper read at ESRC-Conference: Risk in organisational settings, London. 
Mol, A.

1997 'Klant, burger, zieke. Het goede in drie talen.' In: Denken over zong. Concepten en praktijken, edited by M. Verkerk. Lochem: Elsevier/ De Tijdstroom.

Mol, A. \& M. Berg

1994 'Principles and practices of medicine.' Culture, medicine and psychiatry 18 (2):247-265.

Mol, A. \& H. Harbers

1994 Inleiding. Themanummer De aard der dingen. Kennis en methode 18 (1):5-rI.

Mol, A. \& P. van Lieshout

1989 Ziek is het woord niet. Medicalisering normalisering en de veranderende taal van huisartsgeneeskunde en geestelijke gezondheidszong, 1945 - 1985 . Nijmegen: SUN.

Mol, A. \& J. Mesman

1996 'Neonatal food and the politics of theory. Some questions of method.' Social studies of science 26:419-444.

Molenaar, J.C.

1988 'Het nalaten van medisch handelen', Nederlands tijdschrift voor geneeskunde 132: $1925-1926$.

Molenaar, J.C., K. Gill \& H.M. Dupuis

1988 'Geneeskunde, dienares der barmhartigheid', Nederlands tijdschrift voor geneeskunde 132: 1913-1917.

Muller, J.

1994 'Anthropology, Bioethics, and Medicine: a provocative trilogy.' Medical anthropology quarterly $8(4): 448-467$.

Muraskas, J.K., N.J. Carlson \& C. Halset

1991 'Survival of a $280 \mathrm{~g}$ infant.' The New England journal of medicine 324 (22):1598-1599.

Nauta, L.W.

1972 Angumenten voor een kritische ethiek. Amsterdam: Van Gennep.

Nederlandse Vereniging voor Kindergeneeskunde

1992 Doen of laten? Grenzen van het medisch handelen in de neonatologie.

Nederlandse Vereniging voor Kindergeneeskunde.

Nicolson, M. \& C. McLaughlin

1988 'Social constructionism and medical sociology: a study of the vascular theory of multiple sclerosis.' Sociology of bealth of illness to (3):234-261.

Nolan, K.

1987 'In death's shadow: the meaning of withholding resuscitation.' Hastings Center Report 17 (October/November):9-14.

Nussbaum, M.C.

1986 The fragility of goodness. Luck and ethic in Greek tragedy and philosophy.

New York: Cambridge University Press.

Oderwald, A. \& J. Rolies

1989 'Medische ethiek ter discussier: Belangstelling.' Medisch contact 44 (36):1133-34

Oudshoorn, N.

1995 'Technologie en zorg: vriendinnen of vijanden. Het voorbeeld van de nieuwe anticonceptiemiddelen voor vrouwen en mannen.' Gezondheid. theorie in praktijk 3 (3):278-288. 
Oudshoorn, N.E.].

1996 Gendencripts in technologic. Noodlot of aitdaging? Enschede: Universiteit Twente.

Palmer, E. \& D. Noble

1985 'Nurse-nconate relationships: the creation of symbolic interaction within a neonatal intensive care." Sociological spectrum s:331-345.

Peariman, R.A., S.H. Miles \& R.M. Arnold

1993 'Contributions of empirical research to medical ethics.' Theorrtical medicine $14(3): 197-210$.

Pellegrino, E.D.

1995 'The limitation of empirical research in Ethics.' The journal of clinical ethics 6 (2):161-162.

Pillitteri, A. \& M. Ackerman

1993 'The 'Doctor-Nurse Game': a comparison of roo years - 1880-1990.' Nursing outlook 4I (3):ur3-116.

Pols, J. \& A. Mol

1994 'Dus alles is in keurig overleg gedaan. Over patiënten en de overdracht van informatic.' Gezondheid. Throrie in praktijk 2 (2):165-179.

Pool, R.

1996 Vragen om te stenven. Euthanasie in en Nederlands ziekentuis. Rotterdam: WYT. Porter, $\mathbf{S}$.

1991 'A participant observation study of power relations between nurses and doctors in a general hospital.' Journal of advanced mursing (16):728-735.

Porter, T.M.

1995 Trust in numbers. The pursuit of objectivity in science and public life.

Princeton: Princeton University Press.

Raines, D.

1996 'Parents' values: a missing link in the neonatal intensive care equation.'

Neonatal network is (3):7-14.

Rashotte, J., F. Fothergill-Bourbonnais \& M. Chamberlain

1997 'Pediatric intensive care nurses and their grief experiences: a phenomenological study.' Heart of lung 26 (s):372-386.

Recht, L. de, et al

1992 'Camembert, rechtvaardigen en geweldloze liefde. Het politiek-filosofisch-economisch-sociologisch-antropologisch raster van Luc Boltanski en Laurent Thévenot.' Krisis, 12 (2):5-24

Rees, C.

1981 'Records and Hospital Routine.' In: Medical work: Realities and routines,

Reiser, S.J. edited by P. Atkinson \& C. Heath. Farnborough: Gower.

1978 Medicine and the reign of technology. Cambridge: Cambridge University Press.

Reiser, S.J. \& M. Anbar

1984 The machine at the bedside. Strategies for using technology in patient care. Cambridge: Cambridge University Press. 
Rip, A.

1995 'De sociale constructie van wetenschap.' In: Management en wetenschap. edited by Meeren, W. van der \& L. van Langenhove. Utrecht: Uitgeverij Lemma.

Rode, S.S.

1981 'Attachement patterns of infants seperated at birth.' Developmental Psychology 2:188-91.

Roscam-Abbing, $\mathrm{H}$.

1988 Levensbeëindigend handelen bij zwaar-defecte pasgeborenen. Een commentaar naar aanleiding van een rapport van de KNMG-commissie.' Tijdschrift voor gezondheidsrecht (December):467-476.

Schermer, M.

2001 The different faces of autonomy. Ridderkerk: Ridderprint. Schlomann, P.

1994 'Initiating and sustaining ethical discourse in a neonatal intensive care unit: an ethnographic study.' PhD, Department of Sociology. The University of Kentucky.

Schlomann, P. \& S. Fister

1995 'Parental perspectives related to decision-making and neonatal death.'

Pediatric nursing 21 (3):243-254.

Schraeder, B. \& D. Fischer

1987 'Using intütive knowledge in the neonatal intensive care nursery.' Holistic nursing practice 1 (3):45-51.

Seale, C. (ed)

1998 Researching Society and Culture. London: Sage Publications.

Seideman, R., M. A. Watson, K.E. Corff, P. Odle, J. Haase \& J.L. Bowerman

1997 Parent stress and coping in the NICU and PICU. Joumal of Pediatric

Nursing: nursing care of children of families 12 (3):169-177.

Shaffir, W. \& R. Stebbins (eds)

1991 Experiencing Fieldwork: an inside view of qualitative research. Newbury Park: Sage.

Shields-Poè, D. \& J. Pinelli

1997 'Variables associated with parental stress in neonatal intensive care units.' Neonatal network 16 (1):29-37.

Smits, M.J.

1995 'De paradox van de professionalisering. Over zorg en techniek in de verpleging,' Gezondheid: Theorie in praktijk 3 (3):289-300.

Sparshott, M.

1997 Pain, distress and the newborn baby. Oxford: Blackwell Science. Speechley, K.N. \& W.R. Avison

1995 'Admission to a neonatal intensive care unit as a predictor of long-term health: Sporken, $\mathrm{P}$. a 12-year follow-up.' Developmental and behavioral pediatrios 16 (6):397-405.

1988 'Actief doden van ernstig gehandicapte pasgeborenen. Ethische kanttekeningen.' Medisch contact 43 (41):1238-40. 


\section{Star, S.L (ed)}

1995 Ecologies of Knotwledge. Work and politics in science and technolog. Albany: State University of New York Press.

\section{Stein. L.}

1967 'The Doctor-Nurse Game.' Anchives of general poychiarn 16 (6):699-703.

1969 'The Doctor-Nurse Game.' Exc: a review of general semantics 26:205-216.

Stein, L, D. Watts \& T. Howell

1990 'The doctor-nurse game revisited.' The New England journal of medicine $322(8): 546-549$.

Stolker, C.J.J.M.

1989 Van arts naar advocatt. Aanspnakelijkheid voor medische fouten in Amerika. Een les voor Nederland? Dordrecht: Kluwer.

Strauss, A., S. Fagerhaugh, B, Suczek \& C. Wiener

1985 Social Onganization of Medical Work. Chicago: University of Chicago Press.

Strauss, A., L. Schatzman, D. Ehrlich, R. Bucher \& M. Sabshin

1963 'The hospital and its negotiated order.' In: The hospital in modern sociefy. edited by E. Freidson. New York: The Free Press.

Sudnow, D.

1967 Passing On: the social organization of dying. Englewood-Cliffs: Prentice-Hall.

Svenningsen, N.W., L. Björklund \& M. Lindroth

1997 'Changing trend in perinatal management and outcome of extremely low bithweight (ELBW) infants.' Acta peadiatrio supplement 422:89-91.

\section{Svensson, R.}

1996 'The interplay between doctors and nurses - a negotiated order perspective.' Sociology of health of illness 18 (3):379-398.

Swierstra, T.

1994 'Over de waarden der feiten.' In: Burgers en vreemdelingen. Opstellen over filosofie en politiek, edited by D. Pels \& G. de Vries. Amsterdam: Van Gennep.

Taylor, K.M.

1984 'Telling bad news. Physicians and the disclosure of undesirable information.' Sociology of health and illness 10:109-132.

The, A.M.

1992 'Op zoek naar de juiste balans tussen distantie en betrokkenheid.

Veldwerkervaringen van een cultureel antropologe in een ziekenhuis.'

In: Kwalitatieve medische sociologie, edited by A. Goedhals, T. Hak \& P. ten Have. Amsterdam: SISWO.

1997 'Vanavond om 8 uur...' Verpleegkundige dilemma's bij euthanasie en andere beslissingen rond het levenseinde. Houren: Bohn, Stafleu, Van Loghum.

1999a Palliatieve behandeling en communicatie. Een onderzoek naar het optimisme op herstel van longkankerpatiënten. Houten: Bohn, Stafleu, Van Loghum.

1999b 'Emotie en inzicht: eigen onderzoekservaringen als data.' Medische antropologie in (2):323-334.

Tijmstra, T.I.

1987 'Het imperatieve karakter van medische technologie en de betekenis van 'geanticipeerde beslissingsspijt.'. Nederlands tijdschrift voor geneeskunde 131 (26):1128-1131. 


\section{Timmermans, S. \& M. Berg}

1997 'Standardization in action: achieving local universality through medical protocols.' Social studies of sience 27:273-305.

Traweek, $\mathrm{S}$.

1988 Beamrimes and lifetimes. The world of high energy physicists. Cambridge: Harvard University Press.

Tronto, J.

1993 Moral Boundario: a political angument for an ethic of care. New York: Roudledge. Veen van der, W.J.

1996 Liff-saving in the neonatal intensive care unit and its consequences for survivor: A study of the quantity and quality of infant and child life. Groningen: Population Research Centre.

Verbeck, P.P.

2000 De daadkracht der dingen. Over techniek, filosofie en vormgeving. Amsterdam: Boom.

Verloove-Vanhorick, S.P., A.L. den Ouden \& F.J. Walther

2001 'Uitkomsten van een Nederlands cohort van zeer vroeg geboren kinderen uit 1983." Nederlands tijdschrift voor geneeskunde 145 (21):989-997.

Verloove-Vanhorick, S.P. \& R.A. Verwey

1988 'Project on preterm and small for gestational age infants in the Netherlands.' Tijdschrift voor kindergeneeskunde 56 (1):40-42.

Vermeulen, E.

2001 Een proeve van leven. Praten en beslissen over extreem te vroeg geboren kinderen. Amsterdam: Aksant.

Versluys, C.

1987 'Doen en laten sterven aan het begin van het leven. Een persoonlijk standpunt van een kinderarts-neonatoloog.' Medisch contact 42 (35): $1083-1085$.

Vree, F, van

1998 De scherven van de geschiedenis. Over crisisverschijnselen in de hedendaagse historische cultuur. Amsterdam: Universiteit van Amsterdam.

Vries, G. de

1993 Gerede twijfel. Over de rol van de medische ethiek in Nederland, De tuin van pijn en hoop. Amsterdam: De Balic.

2001 'Wetenschaps- en techniekonderzockers, waar is de geest gebleven?' Krisis 2 (1): $62-78$.

Vrolijk, H., G.J. Straten \& T. Weijers

1991 Neonatologie: technologie voor de toekomst. Den Haag: NOTA.

Wackers, G.

1994 Constructivist Medicine. Maastricht: Universitaire Pers Maastricht.

Walters, A.J.

1995 'Technology and the lifeworld of critical care nursing.' Joumal of advanced nursing 22 (2):338-346.

Warner, J.H.

1986 The therapeutic perspective: medical practice, knowledge and identity in America 1820-1885. Boston: Harvard University Press. 
Weir, R.

1984 Selective non-traatment of handicapped newborns: Monal dilemmas in neonatal medicine. New York: Oxford University Press.

Weisz, G. (ed)

1990 Social science perspectives on medical ethics. Philadelphia: University of Philadelphia Press.

Widdershoven, G.

2000 Ethiek in de klinick. Hedendaagse benaderingen in de gezondbeidsethiek. Maastricht: Boom.

Widdershoven, G. \& M. Verkerk

1995 'Technologie en zorg. Inleiding op het thema.' Gezondbeid: throrie in praktijk 3 (3):250-253.

Wilde, R. de

1987 'Tegen het perspectivisme.' Kennis en methode II (4):354-363.

1992 Discipline en legende. De identiteit uan de sociologie in Duissland en de Verenigde Staten 1870-1930. Amsterdam: Van Gennep.

1997 Voorbij de utopische waarheid. Een essay over de relatic tussen waarheid, wetenschap en utopie. Kennis of Methode. (1):39-53.

1998 Reflexiviteit als ideologic. Krisis (71):59-70.

2000 'Innovating Innovation: a contribution to the philosophy of the furure.' Paper read at policy agendas for sustainable technological innovation, 1-3 December 2000, at London.

Williams, B.

1981 'Moral luck.' In: Monal Luck. Philosophical Papers: 1973-1980. Cambridge: Cambridge University Press.

Wittgenstein, L.

1958 Philosophical Investigations. New York: Macmillan Publishing.

Wood, N.S., N. Marlow, K. Costeloe, A.T. Gibson \& A.R. Wilkinson

2000 'Neurologic and developmental disability after extremely preterm birth." New England journal of Medicine. 343: 378-84

Wright, P. \& A. Treacher (eds)

1982 The problem of medical knowledge: examining the social construction of medicine. Edinburgh: Edinburgh University Press.

Zahr, L.K. \& S. Balian

1995 'Responses of premature infants to routine nursing interventions and noise in the NICU.' Nursing research 44 (3):179-185.

Zerubavel, E.

1979 Patterns of time in hospital life. Chicago: The University of Chicago Press. Zussman, R.

1992 Intensive Care: medical ethics and the medical profession. Chicago: The University of Chicago Press.

Zuuren, F.J. van

1995 'Kwalitatief onderzoek. Het belang van een kwalitatieve benadering bij onderzoek in de sociale gezondheidszorg.' Tijdschrift voor sociale gezondheidsorg 73 (5):315-321. 
Zwart, $\mathrm{H}$.

1993 Ethische consensus in een pluralistische samenleving. De gezondheidsethiek als casus. Amsterdam: Thesis.

1995 Weg met de ethiek? Filosofische beschouwingen over geneeskunde en ethiek. Amsterdam: Thesis. 


\section{Summary}

The medical-technological advances of the past decades have been such that entirely new and unprecedented opportunities for treatment have become available. At all levels of the medical domain, new professional routines and sophisticated technologies have radically altered the nature of medical practice. The intervention process has become a much more complicated trajectory, involving more options, other risks, new decision moments, and more pronounced dilemmas for everyone involved. The ensuing uncertainties have contributed to the emergence of a 'gray area', one where the established protocols and the conventional answers found in medical handbooks no longer apply. Yet, as before, many clinical pictures still require immediate medical attention and intervention. To ensure a prompt and accurate response of medical professionals, it will always be important for them to rely on protocols and pragmatic guidelines, the effectiveness of which is always subject to enhancement. In addition, it seems increasingly relevant to examine the new complexities of our advanced-technological health care system in more comprehensive ways as well. Such examination needs to focus on the broad issues directly associated with the various innovations, such as those related to health care management, information systems, and the deployment of new medical technologies. However, given the increasing intricacy of the overall health care process, it is equally relevant to focus on what actually takes place in medical intervention. Although there has been substantial research of some of the quantitative aspects of medical practice, there is still little insight into what is actually happening in hospital wards and the various other domains of the medical profession. This need for this type of study acquires even more urgency, I believe, because it is precisely the established routines and practices of actual medical intervention that are constantly destabilized in a health care system that is primarily marked by rapid change. More than quantitative analyses, then, qualitative studies may lead to a deep and versatile understanding of the ever more complicated interplay of problems and dilemmas associated with the actual realities of contemporary medical practice.

The intensive care unit for newborns in particular constitutes a domain where the challenges and opportunities of new medical knowledge and technology converge. As an outpost of today's health care system where the pioneering 
sprit of medicine reigns supreme, it serves as an exemplary case for studying some of the concrete dilemmas triggered by this permanently changing system. The neonatal intensive care unit (NICU) specializes in the care and treatment of newborns. Very young babies end up in the NICU because their lives are seriously at risk on account of their prematurity, complications at birth, congenital diseases, or potentially lethal infections. As a rule, these patients respond to medical interventions in erratic ways, otherwise they would not be admitted to the NICU. When confronted with a new patient, the NICU staff members generally have little time for taking decisions on a particular course of action, while the baby's vital statistics are often ambiguous if not still unavailable. Moreover, quite soon after having decided on a diagnosis or course of treatment, they may have to face new decisions on whether the adopted approach is effective, on whether the advantages of the technology used outweigh the harm it does to the child, or on whether treatment should be prolonged at all. In today's technological culture the NICU has become a site of rapidly changing medical norms and values. To some extent, the NICU staff always finds itself in uncharted territory, because a specific technology is new or a certain intervention trajectory poses unknown risks, especially given the extreme fragility of the patients. How, then, do all those involved make sure that the medical intervention process does not founder? On what do physicians, nurses, and the children's parents base their decisions? How do the spatial and temporal aspects of the NICU set-up influence their mutual interactions? What role is played by the various ways of reasoning, speaking, and acting in this process? How is a child's prognosis established? These questions are at the heart of this study.

In order to be able to identify the various routines and the often implicit methods and strategies of intervention used by the NICU staff, this study is based on ethnographic research 1 conducted in the 1990 in two neonatal intensive care units: one in the Netherlands and one in the United States. My observations focus in particular on a number of difficult cases and situations in which it was not fully clear what was going on or what had to be done. As a framework for reporting and discussing my findings, I decided to use the journey metaphor. The treatment of children who end up in a hospital's NICU is like a journey that from the very start is full of whimsical incidents and incalculable uncertainties: both the destination and the trajectory are all but predictable. Even if the NICU staff has accompanied children on similar journeys numerous times already, the routes and conditions are never entirely the same. By focusing on a number of concrete intervention trajectories, this study traces the various challenges that all those involved have to face along the way.

For the NICU staff, questions on how to intervene may already arise before the child is born. The problem of intervention is closely tied to the problem of diagnosis and especially in cases that end up in the NICU this involves more than 
just determining the facts. Chapter Two argues that in the context of NICU practice facts are not so much given but construed on the basis of various sorts of materials, including words, numbers, actions, and objects. From the very start, the staff is engaged in assembling and structuring data that help to determine a child's medical situation. The child's identiry is established in a process of reading, measuring, calculating, comparing, combining and discussing data, but also through sensory techniques like observation, feeling, and listening. Throughout this process various styles of reasoning are deployed, including so-called 'case repertoires' and 'situational repertoires'. By moving from one repertoire to the next, or by combining or contrasting them, the staff members arrive at a definition of the situation of the child. The effort that goes into defining the child's situation at the same time helps to shape the NICU as a social practice. In this way the child's identity and the structure of NICU practice are established in a coeval process.

After a child is admitted, its parents become part of NICU life as well. Parents with their own views and backgrounds and staff members with their specific rules and rituals meet each other around the child's incubator. Of course, the occasion for their encounter is hardly a pleasant one and this puts additional strain on the expectations they have of each other. How and to what extent are the social interactions between staff members and parents organized? Chapter Three analyzes the various ways in which in the NICU context the interactions between parents and staff are defined and which vocabularies play a major role. Based on a concrete case, two vocabularies are discussed in particular: the psychosocial and the juridical vocabulary. The use of a variety of vocabularies involves more than just a difference in the use of specific words and concepts. The same words may have different meanings when used in other vocabularies. The application of a specific vocabulary creates a reality in which parents and staff members are each allotted their own place and significance. In a psychosocial vocabulary parents are turned into an object of care; this means that parents need to be given support and protection in an atmosphere of togetherness. Thus the psychosocial vocabulary creates a social order that is marked by a sense of solidarity and shared responsibility. The use of the juridical vocabulary, by contrast, establishes a social order in the NICU that is primarily marked by a sense of individual responsibility. In this vocabulary, parents are seen as bearers of parental authority who ought to have a say in everything that concerns their child, and this means that they are directly involved in every relevant decision for which they are also co-responsible. This view of parents as autonomous, knowledgeable discussion partners in the decision process seems to be at odds with the view of parents as dependent and in need of care: the two vocabularies appear to exclude each other. Yet when difficult decisions have to be made on how a child's treatment should proceed, the deployment of the two vocabularies 
does not necessarily result in a deadlock. In some ways, my analysis of the case demonstrates, they even complement each other, because it is impossible to put all responsibility for a medical decision into the hands of the child's parents who generally lack the expertise to assess medical data properly, while putting all responsibility into the hands of the medical staff would be an unacceptable form of paternalism. The NICU staff, by cautiously maneuvering with both time and language, succeeds in reconciling the two vocabularies. By distributing the responsibility for difficult decisions among all the parties involved, a mode of speaking emerges that allows one to respect parental authority while at the same time providing support to parents.

The shared interest of parents and staff lies in their joint objective: the child's recovery. The recovery of a child that is admitted to the NICU can never be taken for granted, though. Life in the NICU is characterized by continuous struggle and entirely unpredictable changes. The dynamic of its practice is not only determined by the constant flow of activities, the admission of new cases, and the arrival of 'new' parents, but also by the constant fluctuations in the child's situation. The changeable nature of its condition requires around-theclock monitoring and frequent adjustments. In Chapter Four, which focuses on the overall trajectory of a NICU patient, it becomes clear that in the NICU context medical treatment rarely involves merely solving a child's medical problem. The staff has various strategies at its disposal for dealing with the intrinsic tension between the need for intervention and making adjustments on the one hand and the associated risks and uncertainties on the other. Several factors play a major role when tackling the uncertainties of treatment itself, including time, protocols, technical devices, and numbers. Medical intervention in the NICU context does not always involve a race against time. Certain treatment needs time to catch on, or it may require specific preliminary activities. It is nevertheless true that time is a scarcity in many cases, while it may also be a major risk factor. The protocols that are used by the staff tell them in detail what should be done in a given situation; they provide support and direction, but they offer no guarantee whatsoever that a child's treatment will actually follow the anticipated trajectory. In some cases treatment requires major deviations from the protocols, or it can be crucial that nothing is done. To be able to respond promptly, permanent control mechanisms should be in place, and to this end a host of medical technologies has become available. The use of technology, however, has various implications. For one thing, technical devices play an active role in structuring the treatment trajectory. The scripts that are inscribed in the various technological devices in part define the roles and tasks of physicians and nurses, and they also may influence the other tools that are used in treatment. For instance, the respirator's script pre-structures the various options of intervention, but it may also block certain options, complicate a 
child's situation, or trigger the need for making adjustments in the planned trajectory. If it comes to worst, the deployment of technology results in irreparable complications. Staff members try to prevent such a scenario by around-theclock monitoring of the child's condition. They do so by constantly gathering numbers, calculating ratios and quantities, entering quantitative data on special forms and classifying them, and by interacting with each other in numeric language. Numbers function much like a compass that guides staft members in their effort to pilot the child safely along the planned treatment trajectory. Numbers, however, do not speak for themselves, nor can a large flow of quantitative data do away with each and every uncertainty: medical intervention trajectories in the NICU are always rife with risks and uncertainties.

Despite the staff's expertise, the available medical technologies, and a ton of data, a child's treatment can still go way off course, making its recovery highly uncertain. This forces the staff to reformulate the treatment's objectives and the child's prognosis. The parties involved may have quite different views on a particular child's prognosis. Chapter Five is devoted to the phenomenon of prognostic difference and it argues that such difference cannot solely be explained on the basis of the different formal roles of physicians, nurses, and parents in the NICU. In addition to professional expertise, which is generally based on education and knowledge of the relevant literature, more subjective knowledge that is based in personal experience and contact with the child may equally be relevant. The way in which those involved actually spend time with the child or near its incubator, conceived in terms of distance versus proximity, involvement versus detachment, and observation versus touching, results in knowledge that plays a major role in the prognostic process. Furthermore, there are several points of reference that staff or parents rely on when articulating a child's prognosis, such as their knowledge of other children or cases, the technological support mechanisms a child needs, and the temporal and spatial order. The fact that a NICU child's condition is subject to sharp fluctuations seriously complicates the proper assessment of its prognosis. This in part explains why the various incidents that occur in the course of the treatment trajectory have a strong influence on how each one involved arrives at a specific prognosis. Since their concrete knowledge and experience of the child is quite different, they tend to emphasize divergent aspects in its condition.

The child's prognosis largely determines the course of treatment. In case of a bad prognosis, the self-evidence of the treatment's continuation may be questioned or it may even be decided to stop treatment. The dilemmas involved in such a decision are discussed in Chapter Six. Each of the options has serious ramifications. If staff members decide to discontinue a child's treatment they may rob it of its final chance of recovery, but the opposite decision implies the risk that their effort only contributes to the child's senseless suffering. Such 
moral dilemmas may aiready come up before a child's birth, the question then being whether treatment should be initiated after it is born. Protocols, in the form of assessment schemes or decision procedures, aim to guide and direct the NICU staff in taking the proper decision. These protocols, however, start from a problem or situation that is not always identical to the situation at hand. In everyday NICU practice, general moral principles always have to be applied in idiosyncratic ways: they have to be 'custom-made' so as to fit the concrete situation. Basically, the issue of morality in the NICU context involves a decision about fixing a demarcation point, a boundary beyond which intervention is discontinued. To generate a custom-made morality in specific cases, several activities at various moments are required: testing the robustness of facts as well as the flexibility of moral categories; exploring the available maneuvering space; examining disciplinary boundaries and the distribution of responsibilities; searching for the right words; constructing a consensus; and learning to deal with the consequences of a decision. The challenges of NICU life, in other words, require a situated morality in which the distinction between 'general moral category' and 'the child's unique situation' is resolved.

The world of the NICU is all but a neatly arranged world. Here values do not come before or after the facts, but the two categories constantly mingle. Strikingly, though, moral decisions are often seen as a separate category next to medical decisions. The reason for this distinction is found in the difference between action and reflection. It is only afterwards, in reflection, that we can see the reality of deductive moral decisions. The final chapter underscores the significance of this retrospective gaze. Knowing how a particular story is concluded makes a world of difference. In their reflection on a particular course of treatment, those involved have the opportunity to see a neatly ordered world of facts and values, of main issues and side issues. This allows them to review the actions and reassess the choices that were made. Moral reflection emerges out of the order that is retrospectively construed. The intervention trajectory - once so full of unexpected surprises - is now a logical narrative, one that can be interpreted and debated in terms of the moral nature of the acts involved.

The conclusion of this study reconsiders the question with which it began: how does the NICU staff tackle the many complexities involved in the treatment of newborns? To ensure the continuation of the various processes that are part of the treatment trajectory more is needed, it turns out, than expertise, experience, and technology. In addition to the more tangible and concrete actions and interventions of the NICU staff members, more abstract processes are at work as well, and prominently so. Specifically, various styles of arranging and interpretation play a major role in decisions on treatment: repertoires guide processes of reasoning and legitimating, vocabularies suggest ways of speaking and interpreting, and scripts imply more or less explicit directions for action. 
Moreover, it has become dear that protocols and medical technologies have only a limited potential when it comes to facilitating a sound decision process in the NICU context. Technological innovations do not only create new treatment opportunities, but also new questions and dilemmas, as well as new tragic cases; sooner or later, new tragedies and uncertainties will catch up with technological advances. That medical progress causes the boundaries of medical intervention to shift all the time underscores the significance of having protocols and guidelines that allow space for adjustments based on what goes on in actual practice. Finally, it cannot be denied that as a medical practice the NICU - given the particular dynamic of its task and the changing nature of medical facts, norms. expertise, and experience - will always have an uncertain future, just like its staff members will always continue to be pioneers. 


\section{Curriculum Vitae}

Jessica Mesman werd op 2 april 1962 geboren in Berkel en Rodenrijs. Na het behalen van haar MAVO en HAVO diploma aan de Christelijke Scholengemeenschap Melanchthon te Rotterdam, studeerde zij Verpleegkunde aan de HBO-V Vronestein te Voorburg. Na het behalen van haar Colloquium Doctum startte zij in 1985 met de studie Gezondheidswetenschappen aan de toenmalige Rijksuniversiteit Limburg in Maastricht. In 1990 behaalde zij haar doctoraal diploma in de afstudeerrichtingen Theorie van de Gezondheidswetenschappen en Verplegingswetenschappen. In februari 1990 werd zij als Assistent in Opleiding aangesteld bij de vakgroep Wijsbegeerte van dezelfde universiteit. Van 1994 tot 1996 nam zij als toegevoegd onderzoeker deel aan een internationaal vergelijkend onderzoek dat werd uitgevoerd in opdracht van het Duitse Parlement naar controverses over moderne technologie. Vanaf 1996 tot op heden is zij als Director of Studies verantwoordelijk voor de Europese Masteropleiding 'European Studies on Society, Science and Technology' welke in Nederland wordt verzorgd door de Faculteit der Cultuurwetenschappen van de Universiteit Maastricht. Sinds 1997 is zij als Universitair Docent lid van de vakgroep Maatschappijwetenschap en Techniek aan deze zelfde faculteit. 

